$109-8$

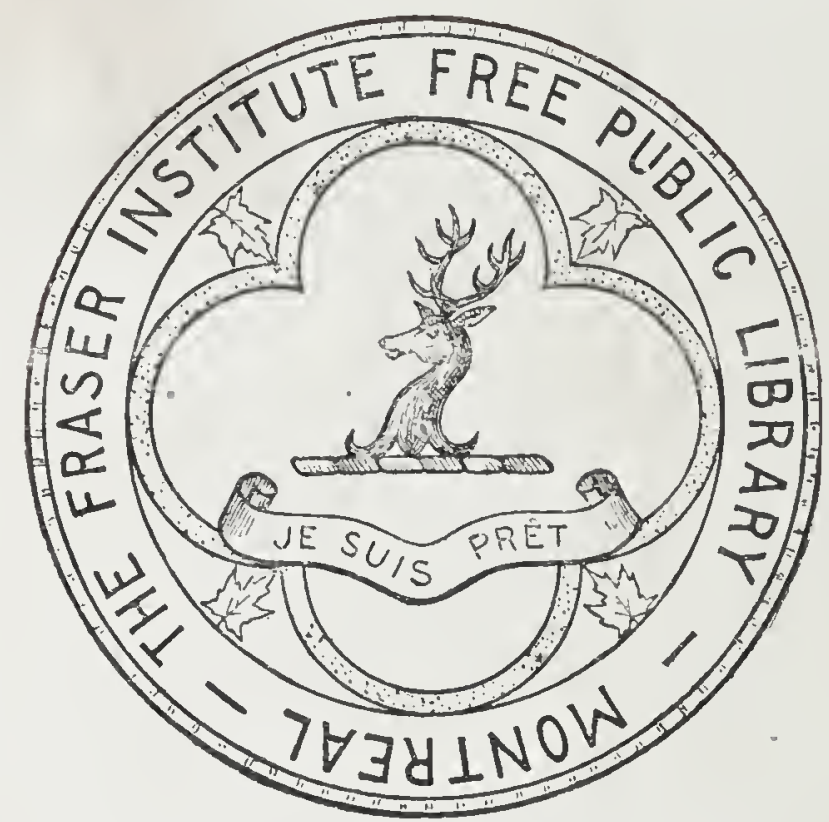

PRESENTED BY

Mus S Greemshields
1918

34881

$109=8$

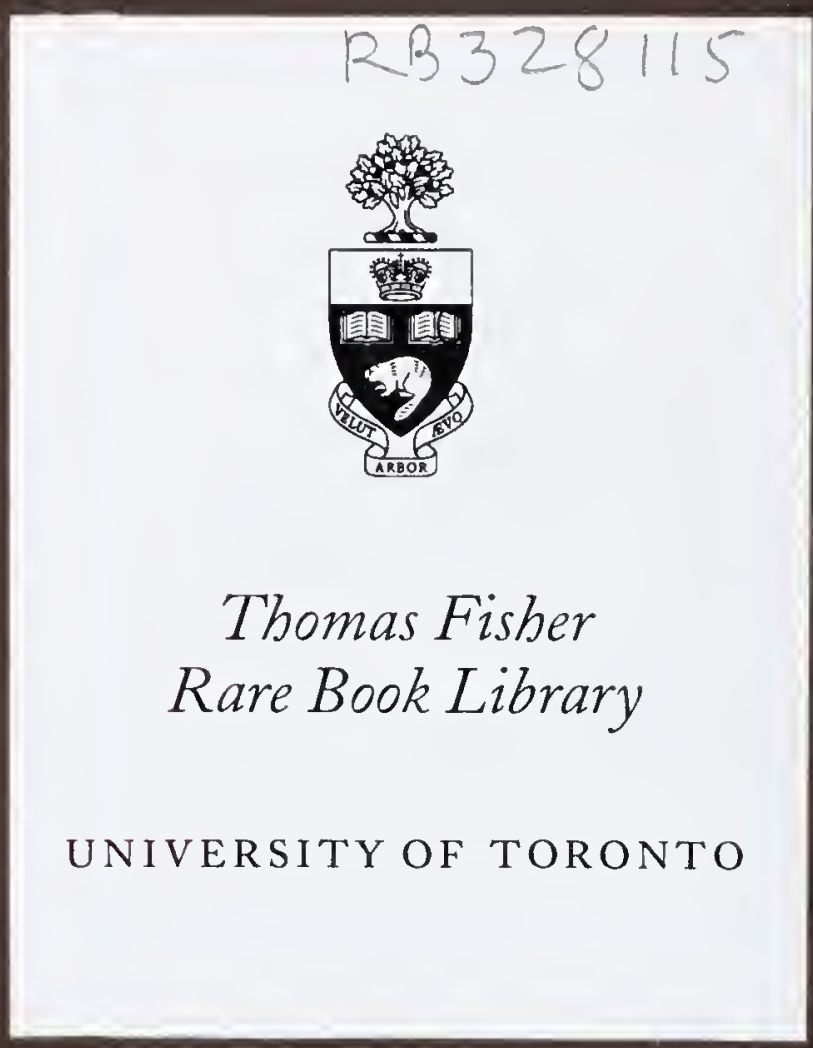




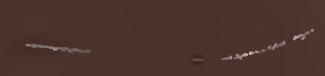

(1) 



MAN AND BEAST. 
Digitized by the Internet Archive in 2019 with funding from University of Toronto 


\title{
HERE AND HEREAFTER.
}

ILLUSTRATED BY MORE THAN THREE HUNDRED ORIGINAL ANECDOTES.

\author{
BY THE
}

\section{Rev. J. G. WOOD, M.A., F.L.S.,}

AUTHOR OF "HOMES WITHOUT HANDS," \&c.

"I canna but believe that dowgs hae sowls."

James HogG, the Ettrick Shepherd.

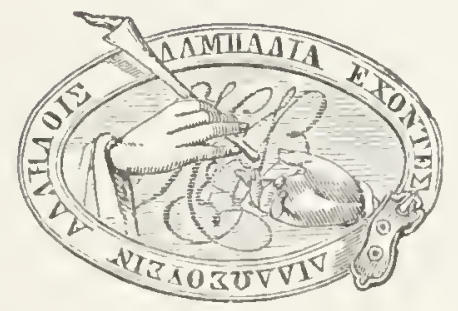

N E W Y O R K :

HARPER\& BROTHERS, PUBLISHERS, FRANKLIN SQUARE. 


\section{BY J. G. WOOD.}

HOMES WITHOUT HANDS : being a Description of the Habitations of Animals, classed according to their Principle of Construction. By J. G. WVood, M.A., F.L.S., Author of "Illustrated Natural History." With about I 40 Illustrations engraved on Wood by G. PEARson, from Original Designs made by F.W. KeyL and E. A. SMITH, under the Author's Superintendence. 8vo, Cloth, $\$ 450$; Sheep, $\$ 500$; Half Calf, $\$ 675$.

Mr. Wood's classification of the habitations of ani- the magnitude of the results compared with the slenmals opens up so wide and connected a perspective derness of the materias attainable. According to this into the psychology of the animal creation that it pos- detinition, many anima!s exhibit far more than insesses quite a peculiar interest and fascination. The stinct--they show genius in the construction of theil' ficts that rats and mice live in holes, and birds make homes. But it is only when we study them on some nests, taken in an isolated way, leaves little impres- such connected plan as that furuished by Mr. Wood sion mpon the inagination of the master-builder unan, that we gradually become iresistibly impressed by drunk with his own glories, who looks with pity and sheer cumulative force, rather than direct proof, with contempt upon dwellings and contrivances which, if the absurdity of the popular talk about blind instinct, not in graudeur, at all events in delicacy of adaptation and can not help seeing the large amount of downright and ingenuity of workmanship, rival his own. Nie- solid intellcct which birds and beasts bring to bear on buhr said somewhere or other that genius is seen in the construction of their homes.-Spectator, London.

\section{Published BY HARPER \& BROTHERS, New York.}

HARPER \& BROTHERs will send the above work by mail, postage prepaid, to any part of the United States or Canada, on receipt of the price. 


\section{P R E F A C E.}

Is the opening of Bishop Butler's "Analogy of Religion" the following passage occur's, showing that this eminent divine considered the lower animals as capable of a future life: "It is said these observations are equally applicable to brutes; and it is thought an insuperable difficulty that they should be immortal, and by consequence capable of everlasting happiness. Now this manner of expression is both invidious and weak; but the thing intended by it is really no difficulty at all, either in the way of natural or moral consideration."

The Bishop then refers to the "latent powers and capacities" of the lower animals, and sees no reason why they should not be developed in a future life. In the present work, I have endeavored to carry out his train of thought, and to show that the lower animals do possess those mental and moral characteristics which we admit in ourselves to belong to the immortal spirit, and not to the perishable body.

The scheme of the book is briefly as follows. I begin with clearing away the difficulties which arise from two misunderstood passages in the Old Testament, and prove that the Scriptures do not deny a future life to the lower animals. I then show that the lower animals share with man the attributes of Reason, Language, Memory, a sense of Moral Responsibility, Unselfishness, and Love, all of which belong to the spirit and not to the body; and that as man expects to retain these qualities in the next world, there is every reason to presume that the lower animals may share his immortality hereafter as they share his mortality at present.

In order to prove that animals really possess the above-mentioned qualities, I cite more than three hundred original anecdotes, all being anthenticated by the writers, and the documents themselves remaining in my possession. 



\section{O N T E N T S.}

Chapter

raOH

I. The Testimony of Revelation . . . . . . . . . . . . . 9

II. Reason and Instinct . . . . . . . . . . . . . 16

III. Reason-(continued) . . . . . . . . . . . . . . 24

IV. Reason-(concluded $)$. . . . . . . . . . . . . . . 32

V. Llinguage [of Anmilis] . . . . . . . . . . . . 39

VI. Language [Human] . . . . . . . . . . . . 50

VII. MEMLRY . . . . . . . . . . . . . . . . . . 60

VIII. Generosity . . . . . . . . . . . . . . 68

I. Cheatery . . . . . . . . . . . . . . . . . 75

X. Hunor . . . . . . . . . . . . . . . . . . . . 79

XI. Pride, Jealoust, Anger, Revenge, 'Tyranny . . . . . . 89

XII. Conscience . . . . . . . . . . . . . . . . 9 ל

XIII. Sympathy and Friendihip . . . . . . . . . . . . 104

XIV. Love of Master . . . . . . . . . . . . . . . 114

XV. Conjughl Love . . . . . . . . . . . . . . . 126

XVi. Parental love . . . . . . . . . . . . . . . 128

XVII. The Future State . . . . . . . . . . . . . 136 



\section{CHAPTER I.}

\section{TIIE TESTIMONY OF REVELATION.}

The Futmre of the Lower Animals, as popularly supposed to be Taught in the Scriptures._The "Bcasts that perish."-If the Literal Sense of the Scriptures alone be taken, the Future Lile of Man is repentedly denied. in the Books of Psalms, Job, and Ecclesiastes.-The Necyomanteia of IIomer compared with the Pralms and Ecclesiastes. - The Futnre State of Man according to Horace._Comparison of the Renderings of Psa. xlix. 20 (the "beasts that perish") in the Hebrew, Greek, Latin, English (Douay version), German, Spanish, Italian, French, Chaldaic, Syriac, and Arabic Versions._Subject of Psa. xlix., and the Real Signification of the Concluding Verse._Opinions of Correspondents. - The "Spirit of the Beast that goeth dow'nward to the Earth."-Subject of the Book called Ecclesiastes.-Teaching by means of Irony.-Distinction between the Spirit of Man and that of the Lower Animals.

Is dealing with a subjeet of this nature-name$l y$, the spiritual condition of the animals inferior to Man-it is clear that we must, in the first plaee, refer to the Scriptures, from which is derived all our authentic knowledge of spiritual life.

There is a popular belief-I should rather say a popular tradition - that somewhere in the Scriptures we are taught that, of all living inhabitants of earth, Man alone possesses a spirit, and that therefore he alone survives in spirit after the death of the material body. If this were true, there would be no room for argument to those who profess to believe the Scriptures literally, and to base their faith upon that literal belief; and, however such a statement migint seem to controvert all ideas of benevolence, justice, and eren common-sense, such believers would be bound to receive it on trust, and to wait for a future time in which to understand it.

Many persous go so far as to deny to animals even the possession of Reason, and only attribute to them the power of Instinct, while there are comparatively few who do not believe that when an animal dies, its life-prineiple dies too-that the animating power is annihilated, while the body is resolved into its various elements so as to take form in other bodies.

'This belief is almost entirely, if not wholly, due to two passages of Scripture, one being in the Psalms, and the other in Ecclesiastes. The

former is that which is generally quoted as decisive of the whole question. It l'uns in the anthorized version as follows: "Nerertheless, man being in honor, abideth not; he is like the beasts that perish" (Psa. xlix. 12, 20).

The Prayer-book version is somewhat different, but is yet translated much to the same effect. "Man, being in honor, hath no understanding, but is compared to the beasts that perish."

The second passage occurs in Ecelesiastes iii. 21: "Who knoweth the spirit of man that goeth upward, and the spirit of the beast that goeth downward to the earth."

On the strength of these two passages, we are called npon to believe that when a beast dies, it dies forever, and that its life is ntterly extingnished as is the flame of an expired lamp. Now every one who has had even a slight acquaintance with the exposition of Scripture is aware that nothing is more dangerous than attempting to explain any passage, however simple it may appear to be, withont making a reference to the original text. 'The translitor may have mistaken the true sense of the words; or he may have insufficiently expressed their signification; or, owing to a change in the meaning of words, a passage may now bear on its surface an exactly contrary sense to that which it conveyed when it was first written.

IIowerer, we will lay aside that point for the 
present, and accept the passage as it stands, together with the literal signification of the worls as generally understood.

'There will then be no donbt that we must believe that beasts have no immortal life. But, if we are to take the literal sense of the Bible, and no otlier, we are equally bound to beliere that Man as well as beast lias no life after death.

See, for eximple, P'sa. vi. 5: "In death there is $n 0$ remembrance of thee: in the grave, who slall give thee thanks?"

Also, Psa. lxxxriii. 10, 11, 12 :

"Wilt thou show wonder's to the dead? Shall the dead arise and praise thee?

"Shall thy loving-kindness be declared in the grave, or thy faithfulness in destruction?

"Shall thy wonders be known in the dark, and thy righteonsmess in the land of forgetfulness?"

Also, see Psa. cxr. 17: "The dead praise not the Lord, neither any that go down into silence."

Also, Psa. cxliii.3: "For the enemy hath persecuted ny soul; he liath smitten my life down to the ground; he hath made me to dwell in darkness, as those that have been long dead."

Also, Psa. cxlvi. 3, 4:

"Put not your trust in minces, nor in the son of man, in whom there is no help.

"His breath goeth forth, lie retmeneth to his earth ; in that rery day his thoughts perish."

If we are to take the Scriptures solely in their literal sense, there can be no doubt of their meaning. The whole range of heathen literature contains nothing more gloomy, dreary, or more despondent in the contemplation of death. "ILet us eat and drink, for to-morrow we die," would be a fit result of such a belief.

In the very book in which occurs the single passage on which is based the denial of the immortality of the lower animals are five passages which proclaim the same end to the life of man. We are told distinctly and definitely that those who have died have no remembrance of God, and can not praise him. Death is described as the "land of forgetfulness" - the place of darkness, where all man's thoughts perish. Can more than this be said of the "beasts that perish?"

Now we will leave the Psalmist, and proceed to other writers. 'Ileating, not of the wicked, but of mankind in general who "dwell in houses of clay," the writer proceeds as follows: "They are destroyed from morning to erening; they perish forever, without any regarding it" (Job iv. 20).

'Take another massage from the same book, a passage which is even more definite in its statement: "As the cloud is consumed and ranish- etl away, so he that goeth down to the grave sliall come up no more" (Job vii. !).

Again-

"Man dieth, and wasteth away: yea, man giveth up the ghost, and where is he?

"As the waters firil from the sea, and the flood decayeth and drieth up :

"So man lieth down, and risetl not" (Job xiv. 10, 11, 12). And rer. 14: "If a man die, slaall he live again ?"

See also the piteous wail of Job over his life as shown in chap. iii. and $x$. In the first he complains that he was erer born, that being was ever given to him, that lie was ever taken out of a state of absolute nonentity. In the second he repeats the same lamentation, with the addition that even death can bring no relief to his sufferings except extinction.

"Wherefore, then, hast thon bronght me forth out of the womb? Oh that I had given up the gllost, and no eye had seen me !

"I should have been as though I had not been; I should have been carried from the womb to the griare.

"Ale not my days few? Cease then, and let me alone, that I mav take comfort a little,

"Before I go whence I shall not return, eren to the land of darkness and the shadow of death;

"A land of darkness, as darkness itself; and of the shadow of death, without any order, and where the light is as darkmess" (Job x. 18-22).

'Turning to the Book of Ecclesiastes, in which occurs the solitary passage which is held to disprove the inmortality of the lower animals, we find the following passages, which are even more emphatic as to the future state of man :

"I said in my leart concerning the estate of the sons of men, that God might manifest them, and that they might see that they themselves are beasts.

"For that which befalleth the sons of men befalleth beasts; even one thing befalleth them. As the one dieth, so dieth the other; yea, they have all one breath, so that a man has no preeminence orer a beast : for all is vanity.

"All go unto one place; all are of the dust, and all turn to dust again" (Eccles. iii. 18, 19, 20).

Also in ch. ix. 5: "For the living know that they shall die, bnt the dead know not any thing, neither have they any more a reward, for the memory of them is forgotten."

Also in ch. ix. 10: "Thatsoever thy hand findeth to do, do it with thy might; for there is no work, nor derice, nor knowledge, nor wisdom in the glave whither thou goest."

'Taking the literal sense of these words and $n 0$ 
other, it is impossible to doubt their import. 'They state definitely that, as regards a spiritual life, there is 110 distinction between man and beast; and that when they die, all go to the same place. The writel also distinctly states that after deatl inan ean work nothing, know nothing, nor can receive any reward. 'The same rein of irrepressible sadness that characterizes the extracts taken from the Psalms is prominent in those passages from Job and Ecclesiastes; and if from these alone we were to dednce our ideas of the condition of man after deatl, most sad and hopeless would be the rery thought of dissolntion.

It is true that we do not accept them in this liglit, knowing that they are written symbolically or parabolically, and that there underlies them the spiritual sense of which St. Paul spealis when lie contrasts the life-giving spirit with the death-dealing letter (' Cor. ir. 6). With tluat meaning, however, we hare in the present case nothing to do. We are only concerned with the literal meaning of our translation, and, according to that literal meaning, if we take two texts to prove that beasts have no future life, we are forced by no less than fourteen passagres to believe that Man, in common with beasts, has no future life. We have no right to pick and choose which passages we are to take literally, and which symbolically, but must apply the sume test to all alike, and treat all in tlie same minner.

Let us pass for a while from sacred to secular literature. All my classical readers must be familiar with that wonderful eleventh book of IIomer's "Odyssey" generally called the Necromanteia, or Inrocation of the Dead. In this strange history Ulysses is shown as descending into the regions inhabited by departed spirits, for the purpose of inroking them and obtaining their adrice as to his future adrentures.

Ie sails to the boundaries of the ocean, and lands in the country of the Cimmerians, who drell in perpetual clond and darkness, and in whose country are the gates leading to the regions of the dead. He utters solemn prayers and invocations, offers sacrifices, and pours their blood into a trencl of a cubit square, which had been consecrated for that purpose. Straightway there throng around the trench the spirits of the dead, eager to drink the blood, and so to be able to hold converse with one who was still a denizen of the upper world. See Pope's version of the passage :

"Thus solemn rites and holy vows we paid

'To all the pliantom nations of the dead.

'Then died the sheep; a purple torrent flowed,

And all the careru smoked with streaming blood.
When lo! appeared along the dusky coasts Thin, airy shoals of visionary ghosts.

Fair pensive youths and soft enamored maids, And withered elder's, pale and winkled shades: Ghastly with wonnds, the forms of warriors slain Stalked with majestic port, a martial train:

These and a thousand more swarmed o'er the ground, And all the dire assembly shrieked around."

The hero stands over the trench, defending it with his sword from the hosts of the dead, and only allowing the spirits to drink the blood one by one. 'Thus he converses with the spirits of' his companions Elpenor and 'I'iresias, then sees his mother Anticlea; and at last the spirit of Achilles approaches. The dialogue between the inliabitant of the earth and the denizen of the regions of the dead must be quoted entire :

\section{"Through the thick gloom his friend Achillcs linew,} And as he spcaks the tears dissolve in dew.

'Comest thou alive to view the Stygian bounds,

Where the wan spectres walls eternal rounds;

Nor fear'st the dark and dismal waste to tread, Thronged with pale ghosts familiar with the dead?'

To whom with sighs, 'I pass these dreadful gates To seek the Theban, and consult the Fates; For still distressed I rove from coast to coast, Lost to my friends and to my country lost. But sure the eye of Time beholds no name So blesserl as thine in all the rolls of fame; Alive we hailed thee with oul guardian gods, And, rlead, thon rulest a king in these abodes.'

'Talk not of ruling in this dolorous gloom, Nol think vain words (he cried) can ease my doom. Rather I'd choose laboriously to bear

A weight of woes and breathe the vital air, A slave to some poor hind that toils for bread, Than reign the sceptred monarch of the clead."

Coleridge well remarks of this passage, and indeed of the whole of the Necyomanteia, that it is "remarkable for the dreary and eren horrible revelations which it makes of the condition of the future life. All is wild and dark; hunger and thirst and discontent prevail. We hear nothing of elysian fields for piety or wisdom or valor, and there is something quite deadening in the answer of the shade of $A$ chilles to the consolation of Ulysses."

Gloom, misery, and rain regrets for earth perrade the whole of this episode:

"Now, without number, ghost by ghost arose, All wailing with unutterable woes.

But swarms of spcetres rose from deepest hell

With bloodless visage and with hideous yell.

They scream, they shriek; and groans and dismal solunds

Stun my scared ears, and pierce hell's utmost bounde. No more my heart the dismal din sustains,

And my cold blood liangs shivering in my vcins."

'These are the ideas of a heathen poet concerning the future state of man. It is no wondel that semsual pleasures should be held the chief 
object in the life of man, when lie is to look forward to such a future as this-a futurc from which neither wisdom nor virtue nor piety could save him - an eternity of gloom, darkness, repining, and hopeless despondence.

Yet, sad as is this picture of the heathen poet, it is far brighter than that of the Psalmist, the Preaclier, or Job.

Those who have passed into the world of spirits do not at all events forfeit their individuality by deatl. 'The youth, the maiden, the clder', and the matron are distinguished in the spirit as they had been in the flesh; and those who had lost their lives in honorable battle retain the stern port and martial demeanor of the eartlily warrior.

Memory is still left to the dead. They remember their earthly career; they do not lose their interest in their friends who still remain on earth; and, above all, Lore survives. Anticlea retains her maternal love for Ulysses, for loss of whom she died; and she watches over the welfare of Penelope and Telemachus. The spirits hold converse with each otler. Those who have been friends on the upler earth resume their friendship in the lower regions. Haughty, selfwilled, discontented in deatl as in life-_6' Impiger, iracundus, inexorabilis, acer" - Achilles still leceives some solace in the constant companionship of his friend l'atroclus.

But, if we are to take literally the passages of Sclipture which have been quoted, no such consolation exists in the future state of man, who passes at death into a place of darkiress, forgetfulness, and silence, where is no work, nor device, nor knowledge, nor wisdom-where even his very thoughts perish. If these passages are to be understood in their pure literal sense, there is no other interpretation to be put upon them; for the statements are too explicit to be explained away or even softened.

According to the outward sense of their writings, the Psalmist, Job, and the Preacher are very much on a par witl IIorace in their absolute unbelief in a future existence, and the rein of melancholy which in consequence underlies their utterances. 'Take, for example, Whittier's short and brilliant analysis of the philosophy of Horace as supposed to be spoken by a friend :

"Speaking of Horace, he gives us glowing descriptions of his winter circles of friends, where mirth and wine, music and beauty, charm away the hours, and of summer-day recreations beneath the vine-redded elms of the 'Tiber, or on the breezy slopes of Soracte; yet I seldom read them without a feeling of sadness.

"A low wail of inappeasable sorrow, an un- dertone of dirges, mingles with his gay melodies. Ilis immediate horizon is bright with sunsline; but beyond there is a world of darkness, the light whereof is darkness. It is walled about by the everlasting niglit. The skeleton sits at his table; a shadow of the inevitable terror rests upon all his pleasant pictures. He was without God in the world; lie had no clear abiding hope of a life beyond that which was hastening to a close. Eat and drink, he tells us; enjoy present health and competence ; alleviate present evils, or forget them, in social intercourse, in wine, music, and sensual indulgence; for to-morrow we must die. Deatl was in his view no mere change of condition and relation; it was the black end of all.

"It is evident that he pliced no reliance on the mythology of his time, and that he regarded the fibles of the Elysian Fields, and their dim and wandering ghosts, simply in the light of convenient poetic fictions for illustrations and imagery.

"Nothing can, in my view, be sadder than his attempts at consolation for the loss of friends. Witness his Ode to Virgil on the deatl of Quintilius. He tells his illustrious friend simply that his calamity is without hope, irretrievable and eternal; that it is idle to implore the gods to restore the dead; and that, although his lyre may be more sweet than that of Orphens, he can not reanimate the shadow of lis friend, nor persuade the 'ghost-compelling grod' to umball the gates of deatl. He urges patience as the sole resonrce. IIe alludes not unfrequently to his own death in the same despairing tone.

"In the Ode to Torquatus-one of the most beautiful and touching of all he has written-he sets before his fiend, in melancholy contrast, tle return of the seasons, and of the moon renewed in brightness, with the end of mam, who sinks into the endless dark, learing nothing behind sare ashes and shadows. He then, in the true spirit of his philosophy, urges Torquatus to give his present howr and wealth to pleasures and delights, as he liad no assurance of to-morrow."

Compare this analysis with that of the Psalmist, Job, and the Preacher, and the result will be found to be the same in all the cases-namely, an inability to beliere in a future life, and a consequent desire to snatch what fleeting pleasures the world can give, before the ineritable Fates consign lim to dark oblivion.

It may seem rather startling to compare the teachings of a Greek idolatrous heathen and of a Latin Epicurean heathen with those of sacred writers. Still more startling is it to show that the teachings of the Epicurean sensualist are no worse than those of the Scriptural writer, while 
those of the Greek poet ate rery much hetter. It is, howerer, the firct, and, if we are to be bonnd by the literal meaning of the seriptures, there is no possibility of denring it without doing riolence to reason and ordinary common-sense.

Now, howerer, we come to the point which was mentioned on page 9. Does the authorized version give a full and correct interpretation of the Hebrew text? It certainly does not. There is no change in the significance of the words, there is no mere insufficiency in the translation, but the rendering is absolutely and entirely wrong. "The word "perish" does not occur at all in the Hebrew text, nor is eren the idea cxpressed. 'The words which our translation twice renders as "beasts that perish" are

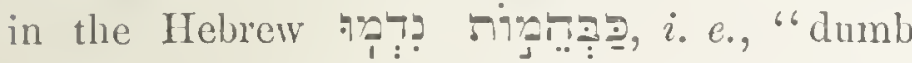
beasts." On comparing a number of translations of Psalm xlix. into various languages, I find that scarcely any of then even imply the idea of perishing in the sense of annihilation. First, we will take the "Jewish Bible," which is acknowledged to be the best and elosest translation in our language, and which has been made by Dr. Benisch, monder the supervision of the Chief Rabbi. Both in verses 12 and 20 the translittion is as follows:

"Man that is in honor", and understandeth this not, is like the beasts that are irrational." A foot-note gives the word "dumb," as an alternative reading for "irrational."

The Septuagint lias rery much the same reading, the verse ending with these words, " $\pi$ apa-

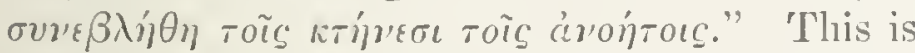
the Vatican text. Sir Iancelot C. I.ee Brunton's translation of the Septuagint runs as follows: "Man that is in honor understands not; he is compared to the senseless cattle, and is like them."

Here is the Vulgate:

"Comparatus est jumentis insipientibus, et similis factus est illis.'

In Trycliffe's Bible, which is a translation from the Vulgate, the passage is thus rendered:

" $A$ man whanne he was in hononr understood not; le is comparisound to muwise beestis, and is mand lijk to tho."

The "Donay" Bible, $i$. e., the translation of the Funglish Roman Catholic College of Donay, heing the rersion which is accepted by that branch of the Church in England, renders the passage as follows :

"Man, when he was in honor, did not nnderstind; lie hath been compared to senseless beasts, and made like to them."

'Ihe lithiopian version, as real by ineans of a
Latin translation, is nearly the same as the Tulgate.

'The French and Ttalian are the only two which resemble our version. The former rums thus :

" L'homme qui est en homnenr, et qui n'a point d intelligence, est semblable anx bêtes qui périssent."

'The Italian is as follows :

"L'uomo che è in instato onorerole, è e non ha intelletto, simile alle bestie che periscono.'

'There is a curious Chaldaic version of the passage, which, according to a Latin translation, adds a few words by way of explanation, and, in these words, places wirled men and beasts on the same level of nothingness afrer deatl. I lave placed the additions in brackets :

"Ilomo [sceleratus] in tempore quo subsistet in honore, non intelligit; cun remoretnl gloria ejus ab eo, comparatur bestiw [et redigitur in niliilum].'

Into some other translations a new idea is imported. 'Take, for example, Luther's Bible:

"Knrz, wem ein Mensch in der Würde ist, und hat lieinen Verstand, so fähret er daron, wie ein Vich."

So the Spanish :

"El hombre quando esteba en lionor, no lo intendio; ha sido comparado á las hestias insensatas, y se ha hecho semejante á ellas."

The Arabic is almost exactly the same as the Spanish, bnt ends with the word Alleluia, which is not in the Hebrew.

'The Syriac version, according to the Latin translation, conveys a similar idea:

"Homo gloriam suam non intellexit, sed aquavit se animanti et similis fictus est ei."

Even smpjosing that the word "perish" is rendered correctly, it does not follow that annihilation is signified. Take, for example, the tentli verse of the same Psalm in the same version :

"For he seeth that wise men die, and likewise the fool and the brutish person perish, and leave their wealth to others."

surely no one would interpret this passage as a declaration that the wise and fools and the brutish hatd no life after the death of the body.

'The last verse of the Psalm is, as Inther puts it, a sunmary of the whole poent. 'The I'salnist draws a vivid pictme of the true object of man's life in this world, and the tendency of man to forget it. He sets forth the shortness of liuman life, and slows that neither wealth, rank, nor fame can endure aftel a man clies, all these things belonging to the mere earthly life of nan. Consequently, men who set their hearts 
upon these earthly things ignore the lionor of their manhood, and degrade themselves to the level of the dumb beasts, whose aspirations are, as far as we know, limited to this present world.

It will be seen, therefore, that we may dismiss from our minds the idea that the beasts are said by the Psalmist to have no future life, and that we may reject the passage as being totally irrelevant to the subject. It is of the greatest importance that this should be done, as the passage in question is the only oue which eren appears to make any definite statement as to the future condition of the lower animals.

Some years ago, when writing my "Common Objects of the Country," I ventured to doubt the truth of the popular belicf on this subject, and was rather surprised at the result. Almost every periodical which gave a notice of the book quoted the passige, and, with only one or two exeeptions, more or less approved of it. 'The exceptional cases were those of distinctly religious publications, and they of course brought against me "the beasts that perish."

I was also inundated with letters on the subject. Many of them were written by persons who had possessed farorite animals, and who cordially welcomed an idea which they had long held in their hearts, but had been afraid to express. Many were from persons who were seriously shocked at the idea that any animal lower than themselves conld live after the death of the body.

Some were full of grave rebuke, while others were conched in sarcastic terms.

Two are specially wortly of notice. The one contains twelve parges of closely written, full-sized letter-paper, in which the writer tells me that any one who cherished the hope that animals could live after death was unworthy of his position of a clergyman, onght to be deprived of his university degrees, and expelled from the learned societies to which he belonged. This argument was so unanswerable that I did not venture to reply to it.

The writer of the second letter remarked that, whatever I might say, he would never condescend to share immortality with a cheese-mite. I replied that, in the first place, it was not likely that he would be consulted on the subject; and that, in the second place, as he did condescend to share mortality with a good many cheese-mites, there could be no great hal'm in extending his condescension a step further.

But, no matter whether the writers agreed with ne or not, no matter whether they were sympathetic, severe, or sarcastic, they invariably mentioned "the beasts that perish." Some wished to know low it was possible to get orer a pas- sage which had always prevented them from indulging in the hope that the animals which they had loved on earth would have a future life; while others brought forward "the beasts that perish" as a crushing and conclusive argument, of which they evidently supposed me to be entirely ignorant.

'The reader will therefore see how inportant it is that the true meaning of the Hebrew text should be known, and that the Psalmist should not be accedited with putting forward a doctrine to which, whether true or false, lie makes no reference whatever.

IYaving thus disposed of the "beasts that perish," let us turn to the passage in Ecclesiastes, which, as we have seen, is the only one which has any direct reference to the future state of the lower animals.

"Who knoweth the spirit of man (or the sons of man) that goeth upward (or ascending), and the spirit of the beast that goeth downward to the earth?" (Eccles. iii. 21).

We have here, at all events, an admission that, whether the spirit ascend or descend, botl man and beasts do possess spirits-the Hebrew word being the same in both cases. 'There is no difference in the various translations, and the rendering in the Jewish Bible is verbatim the sane as that of onl authorized rersion. We will take the entire passage, and not only an isolated text:

"I said in mine heart concerning the estate of the sons of men, that God might manifest them, and that they might see that they themselves are beasts.

"For" that which befalleth the sons of men befalleth beasts; even the one thing befalleth them: as the one dietlı, so dieth the other; yea, they have all one breath; so that a man hatl no preeminence above a beast : for all is vanity.

"All go to one place; all are of the same dust, and all turn to dust again.

"Who knoweth the spirit of man that goeth upward, and the spirit of the beast that goeth downward to the earth?

"Wlierefore I perceive that there is nothing better than that a man should rejoice in liis own works; for that is lis portion: for who shall bring him to see what shall be after him ?" (Eccles. iii. 18 to end of chapter).

The sad, contemptuous irony of the first three chapters of the book tells its own story. Whether or not this book be the production of Solomon in his later year's matters very little. It well may be so, for it is the confession of one who has possessed well-nigh all that earth can give lim, and who lias lived to see its emptiness. Indulgence 
has been arenged by satiety, and the writer's summary of life is contained in the despondent avowal, "Vanity of ranities, all is vanity."

Self-reproach for a wasted life breathes in every page of this book; and the Preacher, speaking from his own experience, shows that wealth, glory, pleasure, and even wisdom are in themselves bint ntter emptiness. P'ractically the theme is the sime as that of the forty-ninth l'salin, though the two writers liandle it in opposite way's. 'The Psalmist approaclies the subject with grave solemnity, warning his hearers of the brevity of human life, and showing that if man forgets the glory of his mimliood, made in the image of God, he places himself on the level of the dumb be:ssts.

'The Preacher takes a different view of the case, thongh he comes to the same conclusion. Limploying biting sarcasm instead of solemm warning, he first shows the utter emptiness of all worldly and selfish pleasures, and the miseralble end of the volupinary, and then ironically advises his readers to place their whole happiness in them.

Briefly, this is the argument: Suppose any one may say that this is liring a mere animal life, what of that? Who could be expected to know that the spirit of beasts is inferior to that of man, and that the spirit of man was made to soar above earthly things, while that of beasts is linited to them?

'The bitter irony is erident, and through the book this idea repeatedly occur's under various forms.

But by no manner of interpretation can the twenty-first verse mean that beasts are amihilated after death, while men rise again. 'The writer ironically assumes that his readers do not know the difference between the spinit of man and that of beast, and, arguing from that assminltion, advises them to live a mere mimal life.

"There is nothing better for a man than that he shonld eat and drink, and that he shonld make his sonl enjoy good in his labor."

I have already shown that the former of these passages does not eren contain the idea of annihilation as regards beasts; and that the latter is entirely misalpurehended is now erident. We may therefore dismiss from our minds both Psa. xlix. and Eccles. iii. as having no bearing whatever on the subject. 'The Scriptmres therefore, as far as we have seen, do not deny future life to the lower animals. Whether they assert it, is not relerant to the present issue. 


\section{CIIAPTER II.}

\section{REASON AND INSTINCT.}

Distinction betreen Instinct and Reason.-Definition of Instinct.-Rarey the Horse-tamer.-Varions Phases of Instinct in Man and Beast.-Definition of Reason.-Comparison between Children and Animals.Reasoning Power's of the Fishes and Reptiles.-Reason Displayed by the Common Toad._The Axoloth and the Horned Toad._Two "Temperance" Dogs and their Masters._"Mess" and his Ways.-Kuowledge of his Regimental Uniform. - Methodical IIabits. - Medicine and Nightcaps. - A Broken Leg and its Consequences._Unexpected Failure of Reasoning in my Dog "Apollo."

IIAvivg now disposed of the purely theological objections to the future life of the lower animals, we proceed to the subject which necessarily follows next in order-namely, the possession of reasoning powers in them.

There is much vagneness of idea on this point, the general tendency being to confound reason and instinct together, and to wonder when one ends and the other begins. For example, there are humdreds of anecdotes, too familiar for quotation or even mention, which are described as wonderful examples of instinct, whereas every one of them is a proof of reason, and has nothing to do with instinct.

When the late Mr. Rarey was exhibiting his wonderful powers of horse-taming in England, I had a long argument with him. It was his custom to prefice his performances by a short lecture, in which he was in the habit of saying that he conquered the animals because he possessed reason and the horse did not. I submitted to him that lis words and lis actions were diametrically opposed to each other; for that, while the denied reason in the horse, erery successive stage in the education of the animal was a direct appeal to its reason.

His success was really due to the higher and more comprehensive reason subduing the lower and more limited; while, if the horse did not possess reason, Mr. Rarey conld have exercised no influence whatever upon it. Indeed, as he had stated in his lecture that dull and stupid horses were more difficult to tame than intelligent and high-spirited animals, he had already granted their capacity of reasoning.

Some years ago I had a standing dispute with my valued friend, the late Charles Waterton. Swayed probably by his religions views, which were of the severest character, he never would admit, and never did admit, that any animal lower than man could possess reason. Yet in all his dealings with the animal world, in which he was simply without a rival, he invariably appealed to their reason and not to their instinct.

For example, he never would allow his farm horses to be tied up or even shnt in their stalls after their day's labor. IIe always had them fed in loose boxes, and the doors left open, so that after their meal the animals conld go into the yard and talk to each other. "We like to chat orer our meals," said the kindly old man, "and so do they."

I remember one case in which the bailiff was within an ace of being dismissed on the spot because one of the men had fastened a horse in its stall. Mr. Waterton quietly took out his penknife, cut the halter into inch lengths, laid them on the floor of the stable, and went his way. $\Delta t$ six next morning the bailiff' waited on his master, looking very much as if he were going to be hanged with a like halter. He knew perfectly well the sort of reception which he would meet, and was evidently relieved when he left the room and found himself still bailiff.

Whenever Waterton showed himself there was a general commotion in the domain, all the inhabitants recognizing their friend and trying to get near him.

One scene I never shall forget. There was a splendid young bull, milk white, one of the many farorites of its master, and the terror of the farmlaborer's. It was a high-spirited and playful young beast, and when let out of the stable used to indulge in pranks that are very becoming to a kitten, but seem rather out of place when performed by a bull.

One morning I accompanied Mr. Waterton through the farm-yard, and he casually ordered the men to let "Tommy" loose. When we came around again Tommy was still in his stall, not one of the men liaring dared to tonch lim. His master, after calling the men a set of cowards, 
proceeded to loose 'Tommy himself, whereupon the men all armed thcmselves witl big cndgels. 'These MIr. Waterton immediately took away again, just as he removed the weapons of his assistants when lie captuled the lumge snake in Guiana, telling them that if they were afraid they might go; which they did.

Ile then loosed 'Tommy, who came plunging out in the exuberance of his freedom, capering about, first on his forc and then on his hind legrs, and tossing bundles of litter into the air with his lorns. Once he rushed at the great feeding-crib that stood in the middle of the yard, knocked it down, picked it up with his horns, and was on the point of smashing it to pieces, when the men, who were in a horrible friglit on the other side of the fence, threw ropes orer it and dragged it ont of the animal's reach.

Tommy then made a charge at Mr. Waterton, and came straight on him with head down as if lie meant to fling him after the crib. I felt rather nervous myself at this; but Mr. Wraterton took it with perfect coolness, and just put his hand on the beast's broad white forehead, saying in a tone of mild remonstrance, "Now then, old boy!" Whereupon Tommy kicked up his heels, gave himself a shake, and next moment was prancing all orer the yard.

There was not the least harm about the animal. He only wanted to let off the superfllous steam, so to speak, and indulged limself in the absurd antics which have been described. It is very likely that if he saw the men running away he would run after them, thinking that they were joining in his game, whereas they thought that he was going to immolate them on the spot.

In a few minutes 'Tommy's exuberant spirits had calmed down, and he was seen quietly lying down in the straw witl his master sented on him, and feeding him with bits of bread out of liis storehouse of a pocket.

I should have liked to have painted that scene : the great white bull lying on the ground with the tall, spare form of his master seatcd on its lunge body ; the litter all tossed here and there by his pranks; the horses, cows, cats, poultry, and all sorts of birds crowding around in hope of scrilus; and in the background the shamefaced laborers, still in undisguised terror of the bull, and in equally undisguised admiration of their master's coulage.

The reader will see here that MTr. WTaterton mas simply gauging the reason of the bull by means of his own, and that, if the animal had only possessed instinct instead of reason, his master would in all probability lrave been killed on the spot.
Let us define clearly the distinction betreen instinct and reason.

The well-known and perfectly correct definition of Instinct is this-"A certain power or disposition of mind by which, independent of all instruction or experience, animals are divected $u n-$ erringly to do spontaneously whatever is necessary for the preservation of the individual or the continuation of the species."

'Take ourselves, for example. It is instinct which tcaches the child to scek its mother's breast and to obtain its nourishment by suction. 'I'his it does in the first hour of its existence as well as if it lod been taught by example and had practiced the art for years. It is instinct wlich teaches the newly born child to breathe, to cry when it is hungry or otherwise uncomfortable, and to clasp with its tiny hand the finger that is put into it.

It is instinct that teaches a lind how to make its nest after the way of its kind, to sit upon its eggs until they are hatched, and to feed the young with their appropriate food. This may seem to many of my rearlers a needless statement, but eren in one of the learned societies of London I have heard a speaker assert that the power of building the nest was not an innate quality, but was communicated to the young by their long observation of the nest in which they were reared. That such an hypothesis is ntterly absurd may be seen from the following facts.

In the first place, although the young pass their first few weeks inside the nest, they do not see the outside, neither can they possibly learn from their parents where the materials were obtained and the mode of putting tliem togrether. Each species, moreover, adheres to the habits of its kind, so that a chaffinch, if bred in a redstart's nest, would build the nest of a chaffinch and not that of a redstart. 'There liave been countless generations of cuckoos, but, althongl every one of them was lored in the nest of a fostcr-parent not of its own species, not one of them has learned to build a nest for irself, but, when it becomes a mother, is taught by instinct to lay its eggs in the nest of some other bird.

Take the case of insects. Instinct teaches the silkworm to make its cocoon, to wait there until it is dereloped into a moth, and then to force its way into the world. It has nerer seen a cocoon before, so that it could not lcarn by initation. Its mother died long before it was hatched, so that it could not learn by instruction. But, tanght by instinct, it forms its cocoon exactly as did its parents whom it nerer saw, and as will its offspring whom it never will see.

All practical entomologists are familiar with 
many instances of pure instinct on the part of insects. One of the most common is furnished by the well-known currant moth, or magpie moth, as it is sometimes called, which may be seen any summer day fitting about the currant buslies, secking for a convenient spot in which to place its eggs. It is a very conspicuous insect from its mottled ycllow, black, and white wings, and is remarkable for the fact that the perfect insect, the pupa, and the caterpillar, all possess the same colors.

'The caterpillar belongs to the group which is scientifically termed Gcometridx, or earth-measmers, and popularly loopers, on account of the mamer in whicl they walk, not crawling like other caterpillars, but drawing up their bodics in the middle into a staple-like shape, and so advancing by successive steps, stretching themselves straiglit and drawing themselves into a loop alternately.

All these caterpillars are provided with spinnerets and silk-producing apparatus, by means of which they can save themselves if they fall from a brancli-an accident to which their way of walking makes them peculiarly liable. As they proceed, with the licad and tail drawn closely together, they attach a thread to the object on which they are walling: and when they stretch forward the body to take a new, hold with the front legs, they draw ont a corresponding length of silken cord. If they should fill, they are brought up by the cord; and if danger should threaten, they let themselves down to the ground, and regain their position afterward by climbing np the suspended cord. Sometimes a knowing bird has been observed to take advantage of this habit, and to shake the branches until the cater pillars had lowered themselves to the ground, when he descended and ate them at his leisure, instead of lunting for them among the branches.

These caterpillars are hatched toward the end of summer, and feed for some three or four weeks, wlien they make preparations for the coming winter, which they must pass in a state of somnolescence. Iet us watch one of them at this period of its life. Its home is within a leaf of the currant or gooseberry, the edges of the leaf being drawn together and fastened by silken cords. But, before doing this, the caterpillar ties the leaf to the branch by several stroug silken bands attached to the stem.

This process completed, the eaterpillar goes into its wintel-quarters, and slceps mudisturbed until spring. In process of time, the laws of nature loosen the leaf from the branch : it call not, lowerer, fall, being iied by the silken cords, and so it only hangs suspended, and swings about eafely in the wind until the following spring.
Now here is a remarkable example of instinet pure and simple. It is ntterly impossible that the caterpillar should know that the leaf would fall in the coming winter-time, and that the threads wonld keep it safely suspended until the warm weatler of the following year.

Indeed, it is absolutely impossible that the creature should even know that there was such a season as winter, or that it would be obliged to live in the state of hibernation for some six months. When it again retires into quiescence during its pupal state it does not act in the same manner, but merely slings itself to the branch by its tail, previously spinning around it a slight eocoon by way of protection.

In both cases instinct, and instinct only, dictated its actions. In the one case it fastened the leaf to the bough, without knowing that the leaf would soon fall; in the otler it slung itself to the branch, without knowing that during the warm days of summer it will need no protection from the elements and little from enemies.

It is instinct which teaches the newly hatched chicken to rum about and peck up its food for itself, while instiuct teaches the young pigeon to sit still in the nest and wait until fed by its mother. Ducks, though hatched under a hen, will instinctively make their way to the water; while clickens, though hatched nuder a duck, will instinctively keep ont of it. Instinct throws a monkey into the most abject terror at the first siglit of a serpent; whilc instinet teaches the secretarybird, at first sight of a serpent, to kill and eat it. Instinct, and not parental instruction, teaches animals to select such food as suits them, and to reject that which would injure them. 'There are certainly some cases whcre instinct fails, as, for example, cattle who poison themselves by eating tlie leaves of the yew. But, in these instances, the cattle are domesticated, liave not been obliged to depend wholly on their own efforts for procuring food, and their instincts hare in consequence lost much of their porrer.

It is instinct which directs with unerring accuracy the eormorant to plunge into the water and to capture the swift fishes in their own element. It is instinct which tells the mole to find its food beneath the earth, and the swallow to catch the flies in the air. 'Tlie swallow never tries to catcli fish, nor the cormorant to chase flies, each being endowed from birth with the power of knowing its proper food and the means of obtaining it.

It is instinct which teaches the dragon-fly, an active inhabitant of the water, and the dronefly, an absolntely inactive inhabitant of the mud, while in their larval states, to take to their wings 
as soon as they have attained their perfect condition, and to dart through the air quicker than the eye can follow them. They use their wings at once with as much skill as if they had learned under skillful teaching and with long practice.

It is instinct, and not reason, that forces the birds to migrate, and which guides them in their long journey's.

Man, as well as the lower animals, has his instincts; but, as he is able to bring most of them in subjection to his reason, very few of them are apparent. Some, lowever, remain and assert themselves throughout the whole of human life.

Reason differs from instinct in the widest possible manner, the former being an exercise of the will, and the latter independent of it. Instinct is implanted at birth, while reason is an aftergrowth of the inind. Instinct requires no exercise of thought, while reasoning may be briefly defined as a deduction of a conclusion from premises. This power is possessed by animals in common with ourselves, although not to the sume extent; and it is by the superiority of our reason over that of the animals that we maintain our supremacy. Very often their deduction is insufficient, or their premises false; but the process is still one of pure reason, and has no connection with instinct.

With them, as well as with ourselves, reason often conquers instinct, especially in the case of those animals which are domesticated, and so develop their reasoning powers by contact with reason of a ligher quality than their own. For example, if a hungry dog or cat be in a room where food is left unguarded, their instincts urge them to jump upon the table and satisfy their hunger; if properly trained, however, their renson restrains their instinct, and, no matter how hungry they may be, they will not touch the food until it is giren to them.

I liad scarcely written these words when I received the following aneedote, which shows the power of reason over instinct in exactly the manner which I have mentioned:

"A cat of ours once showed great self-denial. She was a terrible eater of small birds, chickens, etc., and therefore, when on one occasion she was found to have passed the night in our aviary of dores, great was the alarm. IIowever, on inspection, not one dore was missing; and though she was asleep in an inner cage, close to a nest of young dores, she liad not tonched a feather. What mate her conduct the more remarkable was the fact that on being released slie ate ravenously."
It is just the same with onrselves. A child that has been well brought np can be left with perfect safety alone with any kind of dainties, the parents having taught its reason to conques. its instincts. Whereas a spoiled or ill-bred child, which has been suffered to allow its instincts to be paramount, will be sure to fall upon the coveted dainties as soon as it is left alone, and probanbly to make itself very ill. Surely the conduct of both the animal and the child is identical.

In the human idiot we have too frequent examples of the terrible power of instincts or propensities, as they are sometimes called, when the reason is insufficient to counterbalance them.

Almost any animal can be thus trained to subject its natural instincts to its reason. I have a letter from a lady, who writes that she has a pig which for good manner's and cleanliness is as fit for a drawing-room companion as any lap-dog.

The distinction between reason and instinct is strongly defined in the conduct of a dog who possessed both qualities in a rery superior degree.

The animal in question was named "Don," and was in his master's opinion the "prince of pointers." His scent was extraordinarily keen. For example, one day, when out shooting, he suddenly came to a point, and stood like a rock. His master went up to him; but no game rose, and still the animal continued to point. His master walked on in the indicated direction, nntil he was stopped by a stone wall, and on looking over it he saw a hare closely cronched to the gromnd. The keen scent of the dog had detected it in spite of the intervening wall.

As often happens, birds got wild toward the end of the season, and used to rise while out of shot. Now "Don" knew the range of the game as well as his master, and invented a singularly ingenious mode of literally circumventing the birds.

His peculiarly keen scent enabled him to detect them at a considerable distance, so that they would not be afraid of him. Instead of going directly toward them, "Don" used to circle around them, gradunlly contracting his lines until he eame within range. He would then look back at his master, as if to say, "It's all right, we have them now ;" and so they had.

Here we see both characteristics developed to the fullest degree, the lower being controlled, by the higher, and used as its tool. 'The singularly keen seent was purely instinctive, and had nothing to do with reason. But the reasoning powers of the animal enabled him to employ his instincts in the service of his master. First, he had observed that the gun was never used beyond 
a eertain range, and had eome to the conclusion that beyond that range birds could not be shot.

Then he had observed that when birds were wild they rose out of distance, and so set himself to invent some plan by which they would not take alarm while ont of shot. The device which he practiced was exactly that which is at the present day employed by the lunter's of Sontl America. If they see a partridge in the plain, they ride around and around it in ever-narrowing circles. The bird lies closely crouched to the ground in hopes that it is not observed, and the horseman at last approaches so closely that he is able to kill it witl a blow from the metal handle of his whip.

Fishes are not supposed to be possessed of much reason; yet every angler knows that all the powers of his mind are taxed before he can induce an old and wary tront to take his bait, or, when he has succeeded in hooking the fish, to prevent it from breaking his line.

The natural instinct of a fish teaehes it to fly from man, and we all know that even our shadows on the water will frighten away the fish and destroy the angler's hopes of success. Yet I know a pond full of gold-fisl which are quite tame, and which, when they see a human being at the side of the pond, come toward lim instead of being alarmed. If a little rippling be made on the surface of the water, they come crowding to the spot, that being the signal for food; and so perfectly confiding are they that they will take bread or biscuit out of the hand, and if the hand be kept under the water, one or two of the fishes will presently be nibbling at each finger.

Here then is an example of the instinct, which urges them to flee from man, being overcome by the reason, which tells them to approach him. I have seen an electric eel fed in just the same manner: The creature was blind; but it at once recognized the ripple, coiled itself around the spot where the witcr was agitated, and with a shock killed a fish which the keeper had placed there. At the British Museum there are now some Axolotls kept alive in a glass vessel. They are sluggish creatures, mostly lying at the bottom of the ressel; but if the water be agitated, up they come with open mouths, expecting the strip of meat with which they are fed.

This conduct is a distinct deduetion of a conclusion from premises, and, so far from being dictated by instinct, is absolutely opposed to it. If the reader will keep in mind the definition of reason, he will see that, in all the anecdotes which are narrated in this and the two succeeding chapters, reason, and not instinct, is the motive power.

The following account of a tame "Horned
Toad," or "Horned Frog," as the animal is called, is written by one of my brothers. I may first state that the creature in question is neither a toad nor a frog, but a lizard belonging to the great family of the Igumas. Its native popular name is Talpayaxin, and it is known to science as Phrynosoma Blainvillii. 'The former of these names is composed of two Greek words signifying toad-bodied, and is given to the creature on account of its flat, toad-like aspect.

"The Ilorned 'Tond, so called by the people of the regions inhabited by this curions reptile, is a very oddly shaped lizard, measuring when full grown about six inches in length, of which the tail occupies one and a half inches, and three inches across the back, which is enormonsly wide and flat when compared with the little and elegant forms of the lizards in general.

"The head, back, and tail are thiekly planted with spines, which in the full-grown animal look exactly like those of the black-thorn. The head from behind the eyes radiates spines; the back is covered with them, some large and some small. 'T'le two edges of the belly are set like the teeth of a saw, as is also the tail, which appendage is short for the size of the animal, and tapers from three quarters of an inch at the base to a point at the extremity, being a distanee of only an ineh and a half.

"This lizard, probably from its form, is not nearly so active as its race generally are-even when disturbed seldom rumning more than three or four feet, and then stopping close to some stone or root, to which instinct teaches it it bears a close resemblance, and trusts to that resemblance to escape detection, in which it often succeeds, as in such cases none but an eye educated in observation ean traee the fugitive, or detect in the apparent root or stone a living reptile; on these occasions a quiek grasp of the hand will mostly secure it alive.

"The facility with which these strange creatures are tamed is almost ludicrous in its effects. When seized in the hand, it endeavors to escape by repeatedly pressing its head against the detaining fingers of its captor, in the loope that the spikes with which it is armed will effect its deliverance; but then if the head is allowed to protrude from the hand and gently stroked, and the monder-jaw treated in like manner, in less than a minute the eyes close and the creature is asleep; and it will be found, npon awakening, that the timid, shy lizard is completely tamed. This curious process I lave tried on some eight or nine specimens without a single failure.

"When thins tamed, these lizards make the most engaging pets possible, their forms are so 
strange, and their actions so quaint and oldfashioned in the extreme. They are very chilly creatures, reveling in the mid-day sun, and hiding away in some warm corner when the sun goes down; in the wild state they scrape a small hole in the sand, heated by an almost tropical sun, and lie there during the night, until the warm rays of the morning sun again arouse them into activity.

"This habit showed itself to me in a very curious manner. I had caught some seven or eight specimens, and put them in a box with about an inch of sand at the bottom, where they ran about merrily enough during the day; but next morning, when I looked to see how they were getting on, not one was visible, and I naturally supposed that they liad taken French leave and escaped. But after the lapse of an hour or so I heard a scratching in the box; and on looking in, there were all my little friends, some rumning about, others stili half buried in the sand. This led me to suspect their habits, and so next morning, just after sunrise, I went to the place most frequented by them, and sat down patiently to watch for them. In about half an hour my eye caught a movement in the sand about half-a-dozen yards to my right, and, after a moment or two, out came a lizard, and before an hour had passed I had seen four come out of their sandy beds.

"I hear from those who have traveled on the greater part of this continent that this lizard is only found in the Sage-brush district, and never near water or damp places. It is also stated that one of these reptiles may be placed in a bottle, corked and sealed up for years, and will be as lively at the end as when first put in. I have commenced an experiment on this subject, On the 1st of September I placed four specimens in different bottles, corked, sealed, and then, over all, several layers of tinfoil tightly pressed down.

"I have had one very large specimen living at large in my bedroom for the past six weeks; during this time he has on several occasions gone out of doors on fly-catching expeditions, but always returned to sleep under an old piece of cloth in one corner of the room; and even when outside, where a run of a couple of yards would give him liberty, he will always allow me to pick him up without trying to escape.

"But of all the amusing proceedings on his part is his way of catching flies in the room.

"During the latter part of the dav the sun shines through a hole in the shutter of my bedroom, and makes a nice warm spot on the floor alongside one of my portmanteaus, and on this spot the flies 'most do congregate;' so my little pet, who is not quick enough to catch the flies in fitir chase, climbs on the top of the portman- teau, and, lying half on and half off, watches his opportunity, and woe to the unfortmnate fly that settles below him; the instant the fly is quiet the lizard gives a few preliminary curls to the tip of his tail, just as a cat does when watching a mouse, and then tumbles down bodily upon the heedless fly, cuddles his prey between his fore legs and chest, and then, bending down his head as far as possible, allows the fly to struggle out of his embrace, when with one quick motion of his tongue the poor fly has disappeared. After a moment's rest, up he climbs again, and is ready to repent the process.

"I have once counted seren flies caught in this manner within an hour, and, during the whole of the time that I have had him, I have only seen him miss twice in catching the prey upon which he had fixed his eye.

"As the nights are getting colder, I notice my pet is daily becoming more lethargic in the morning, and from this assume, in all probability, this species hibernates during the winter. I hope to be able to make some few experiments upon this subject during the coming winter, and the results, if any, shall be duly forwarded for publication."

The writer of this notice sent me a Tapayaxin by post. It arrived in perfect health, and lived for some time; but I have no hot-house, and a severe winter killed it.

The reader will probably have observed that in this mode of catching prey the creature was guided by reason rather than by instinct. It had observed that the flies were in the habit of settling on the spot which had been warmed by the sunbeam, and so took advantage of the portmanteau as a post of vantage whence he would leap, or rather fall, upon his prey.

If there be any animal in which we should look for reasoning powers, it is the dog. I propose, therefore, to give a few original anecdotes of this animal, in all of which the power of reason will be evident. In the course of this work many other anecdotes will be related, both of dogs and other animals, in which their power of reason will be shown; but as the anecdotes have a more distinct bearing upon other attributes, such as lore, hate, sympathy, generosity, etc., they will be placed under those respective heads. In the two anecdotes which follow it seems as if the man and the beast had almost changed places. At all events, even if the animals clid not possess more reasoning powers than the men. they exercised those powers which they did possess to a better purpose.

"I had a friend who possesses a little blackand-tan English terrier. Ilis master had the 
misfortune not only to prefer two glasses of grog to one, but greatly to prefer three or four, with the usual consequences. On one of these occasions he beat his dog severely, and from that time the dog, whenerer there was a recirrence of the fourth tumbler, went and hid himself in the cupboard, never showing limself until the effects had passed off, and his master was restored to sobriety.

"I know of another dog, a Scotch terrier, whose master is extremely fond of him, and the attachment is mutual. At times this gentleman exceeds the bounds of prudence, and, when he does so, the bout lasts for two or three days. Although on these occasions he is quite inclined to fondle and make much of his dog, the animal will not go near his master, nor even look at him, but shms him in every way, and keeps aloof until his master is restored to a perfect state of sobriety."

There was a Scotch terrier dog who lately died, to the very great sorrow of his master, an officer in the 45 th Regiment, and the very great rejoicing of his master's friends. He was good enough to honor me by admitting me among his friends - the only person not belonging to the family to whom he extended that privilege. His name was "Mess," which was a military abbreviation of "Mesty," which was an abbreviation of Mephistopheles, the name being given to him in consequence of his temper, which really deserved the name of infernal. No one, except his master, his master's family, and an exceptionally favored servant or two, could put a hand on him without being bitten. I know a learned barrister who has been kept in bed mntil a very late hour in the morning because "Mess" had come into his room when the servant brought the hot water and wonld not allow him to get up. As long as he lay still in bed, "Hess" sat quietly on the floor ; bat at the least movement "Mess" sprang up with a menacing growl, flashing eyes, and gleaming teeth, and the unfortunate guest had to subside again, unable even to ring the hell for help, and anxious that his host and hostess must be waiting breakfast for him and chafing at his laziness.

One day I paid a visit to "Mess's" master, not knowing any thing about the dog, and not seeing the dog when I arrived. Being accustomed to an early walk before breakfast, I started off as lisual on the following morning, and on returning met a little procession, consisting of a nurse-maid leading a donkey, on which were the two daughter's of my host in panniers, and a reniarkably fine Scotch terrier, which was trotting along in frout. As soon as he saw me, the dog sprang forward, and I, not knowing any thing of his character, and thinking that he wanted a game, stooped down, patted him, rolled him on his back, pretended to box his ears, put my hand into his month, and, in short, let him have his game. The nurse-maid stood by almost paralyzed with horror: but why she should be frightened seemed rather mysterious.

On coming to breakfast I spoke in high terms of the splendid dog with whom I had enjoyed a game, and the host was almost as horrified as the nurse had been. Not until then did I hear abont the dog's temper'; but, whaterer it was, it was never displayed toward me, and I believe that I am the only person not belonging to the fanily who was ever allowed to put a hand on him. I may mention that a life-sized portrait of "Mess" was taken in crayons by Mrr. Waterhouse Hawkins, and occupies a place of lonor in his master"s dining-room.

Some years ago "Mess" and his master were stationed at Parkhurst, where was a dépôt. Although several regiments were represented, "Mess" perfectly knew the green facings of his own regiment, and would recognize men belonging to it, but no others. 'This, by the way, was the more curious, as all the troops wore the scarlet coat. He had a way of being present at the morning parade, and then going off to the barrack-rooms to breakfast. He had arranged in his own mind a regular series of rooms to be visited; and if the men succeeded in decoying him into a room which did not correspond with the day, he bit somebody and went off to the right room.

There are many officers and men of the 45th who perfectly recollect "Mess" even after the lapse of several years.

Once, while home on leave, his master was taken with a fit of illness, "Mess," as a matter of course, keeping guard. In the comrse of the night the necessary medicine was brought by the patient's mother, who wore a rather elegant nightcap, reserved, as she used to say, in case of fire. The medicine happened to be peculiarly distasteful, and the patient gave an involuntary shudder. Whereupon "Mess," thinking that his master was being injured, flew at the lady, and never afterward would endure the sight of a feminine nighteap.

"Mess" was good enough to extend his friendship to his master's father, a surgeon, and condescended to accompany him on his rounds, sitting in great state on the box. One day he fell off as the carriage started, and the wheels went over him, breaking one of his legs. He would not allow himself to be touched, except by the sur- 
geon's hands; and to him he was quiet and annenable, allowing his leg to be set and laid in splints without showing the least anger, and being evidently grateful for the services rendered to him. The leg rapidly recovered, and "Mess" was at his master"s country-house when the surgeon came to pay his son a visit. No sooner did "Mess" see him than, although his injury had long been healed, he began to limp, went to his old friend, rolled orer on his back, and held up his leg. Nor wonld he desist until a handkerchief had been tied around the leg and some water poured over it. Afterward, when he happened to injure a paw, he went of his own accord to the surgeon, held up the damaged limb, and asked for help as plainly as if he possessed liuman language.

We shall hear more of "Mess" in succeeding pages, but meanwhile it is impossible not to see that the actions of the $\operatorname{dog}$ proceeded from real reason. Sometimes his premises were false, as in the case where lie kept the guest in bed, or when lie must needs have the sound limb dressed; but there is no doubt that he did draw a conclusion from premises, and that therefore lie possessed reason.

A lady of my acquaintance once saw a curious instince of reasoning in a toad.

She was sitting in a garden, when she saw something alive moving along the base of the wall, which was an old one and full of crevices. The object proved to be a large toad, which was examining the wall in a most systematic fashion. She saw the creature raise himself on his hind legs, peer into a crevice first with one eye and then with the other. 'Then he tapped the wall with his paw, and pushed it into the aperture. Evidently dissatisfied, he went away, and tried another crevice in the same manner and witl the same result. A third, however, was larger than the otliers; and this seemed to be to his taste, for he slowly drew himself up the wall and disappeared into the crevice.

It was evident that the creature knew his own dimensions, and was taking measurements of the crevices in order to find one that would allow him to enter. Toads, by the way, possess sufficient reason to be easily tamed, and to come at a eall. My children generally liave some tame toads in the summer-time, and are in the habit of carrying them around the garden, and holding them up to let them catch the flies and other insects that settle on the flowers. The creatures are so accustomed to this mode of being fed that they do not require to be held, but sit quietly on the open hand.
It is rery curious to note how the reason of the lower animals suddenly fails just where least expected. My bull-dog, "Apollo," an animal of peculiar intellectual powers, once displayed a singular example of this sudden fatilure.

I was walking out, with Apollo as usual at my lieels, when I met a party of friends, who began to ridicule the dog, saying that he was of no use except at a dog-fight, and could not even fetch or carry. I answered by throwing my stick, a heavy "Penang lawyer," over a high park fence standing on the top of a steep bank. Apollo dashed after it, and, being lithe and active as a greyhomd, he sprang up the bank and fairly leaped the fence, just helping himself over with lis legs.

Presently we saw his round head come up on the other side of the fence, the stick being in his jaws. It was so heary that he could not even get his fore legs on the fence, and so he ran along the inside trying to find an outlet. $A$ s the fence had been recently repaired, he eould not find an exit, and straightway set about making one. He put down the stick, and deliberately bit a hole through the fence, tearing away the oak planks as if they werc pasteboard, until he had made a hole through which he could pass. He went through the hole, put his head into the field, took the stick in lis mouth, and tried to pull it after him. As, however, he had grasped it by the middle, the stick naturally resisted his efforts.

I thought that the dog would be sure to take the stick by one of its ends, and so pull it throngh; but, instead of doing so, he went back into the field, and tore away the fence till he had made a hole large enough for the stick when held by the middle.

This story is the more remarkable because other dogs, certainly not of greater mental calibre than Apollo, have resolted to that rery simple mode of getting out of a difficulty.

For example, I have a letter before me in which is an accomnt of a dog who had been sent into the wates after a wooden riil about eight feet long and several inches wide. The animal took it by the middle, and swam with it to the only place where a landing was practicable; but, finding that there was not sufficient space for the long rail, he swam ont again, turned the rail around, took one end in his month, and so bronght it ashore. Presently his master tllrew the rail into the water again, and this time the dog took it by the end at once in order to bring it in, never seizing it by the middle after his first failure. 


\title{
CHAPTER IIT. .
}

\author{
REASON-(continued).
}

History of a Friend's Dogs._- "Pincher" and his Mistress._- Pepper" and the Velvet Cat._The Maltese Dog and Lady C.'s Carriage._- "Joey" and the Alarmed Houschold.-Joey's Last Days._Dogs Discovering Li rhted Gas and Unfastened Doors at Night._The Cat Detective._Dogs Understanding the Use of Money. - The Penny and the Red-hot Iron.-The Margate Dog and the Baker._The Suicide's Dog._The Hat and the Walk. - Hide and Scek.-A Too-conscientious Dog._The Terrier and her Hiding-place._- "Bosco's" Curiosity Gratitied.-A Gallant Rescue and Deserved Castigation.-Acquisitiveness in a Dog.-Lord M.'s Dog and the Rnnaway Horse.-The Retriever and the Hedgehog.-Conrtesy to Ladies. - An Ass too Clever to be Kept.-Various Modes of Opening Doors.-The Clever Mule._A Morning Caller.-The Monkey, the Cage, and the Strap.

A LADY who has a great fondness for animals, especially dogs, has kindly sent me a few anecdotes relating to traits of character among her pets. 'The following have been selected as examples of reason in the dog, though other traits are also manifest.

"Poor old Pincher! His name was most old-fashioned and unaristocratic, and he was one of the occupants of our stable-yard, and never allowed to enter the house. His education was totally neglected and uncared for. He was a middle-sized, smootl-haired, black terrier, and had acquired some peculiar ways of his own.

"In liis time we were in the habit of spending about two days per week at our country-house, ten miles distant from Canterbury. Pincher generally accompanied on carriage, and seemed to enjoy these country days as much as any of us. On one occasion, home-engangements had prevented us from paying our accustomed risit to Harnden. Pincher disapplered of the alteration, as he started off with the carriage as nsual; but when he found our destination was not Harnden, he refused to fullow, but turned off to the house, went the whole distance (mystifying the servants there, who expected ns to follow), remained there until evening, and then returned home.

"Years later the poor" dog became too old to accomplish the whole distance. He could not walk, and would not ride; so he adopted the expedient of going about half-way with us, always waiting at the same spot until our return, and then following us home."

"A little Scotch terrier, named 'Pepper,' one of our former pets, was, like most of his relatives, a capital fellow for hunting a rat, a cat, or a mouse. He was onl companion when calling on an old lady, where I thought we could take him without any fear of his hunting propensity causing annoyance, as I knew she had no living pet of any description. We had scarcely entered the spacious drawing-room, when, from underneath an Indian cabinet at the extreme end of the room, our dog Pepper saw two large, glassy, yellow eyes glaring at him with more than natmral ferocity. Without waiting to use his power of scent, he rushed fiercely on his imagined foe, which fell lifeless at his feet, Pepper retreating to our side, litnging down his tail, and looking more like the ranquished than the victor.

"Do any of my reader's remember those now unmade cats of pasteboard and black relvet texture, those now non-existent ornaments of former days? Such was Pepper's foe. Dogs know well enough when they are the objects of ridicule, and, finding we were all laughing at his discomfiture, he retumed to the velvet pussy, and in playfurl mood carried her around the room, evidently wishing to hide his mistake by convincing us that it had only been a sham fight from the beginning."

The action of the dog here is very human, and it behaved just as a clever child might be expected to do when it had been deceived, and was afraid of ridicule. In the next anecdote the reasoning powers of a dog are seen to be at fault, as they sometimes are with human beings.

"The dog which we now have, thongh not an equestrian like his predecessor, is exceedingly fond of carriage drives; and if a well-appointed carriage should draw up, he will ofter stop, and look up most pleadingly at the coachman to have 
the door opened. Of comrse he has had many drives rith us in cabs, but he never of his own accord enters one of these velicles.

"We have been lately staying in town, and the day aftel our arrival we went out, followed by our little dog. IVe had just passed through one of the large squares, when we missed our favorite. With only a finint hope of finding him, we retraced our steps to the square, where a handsome carriage, with coachnan and footman, was drawn up at the door of one of its most stately mansions. WVe asked the footman if he had seen a little white Maltese dog in the square. 'Yes, madam : as soon as Lady C- got out of the carriage, he jumped in so quickly that I had not time to prevent him, seated himself on the cushion, and defied me to remove hin.'

"' 'There he was, evidently waiting for us. Just at that moment her ladyship came out of the house, accompanied by her little pung-dog. In jumped the pug, down jumped the Maltese, and there was a sharp fight, which was ended by my removal of the usurper. We were only too glad to find lim again, and Lady C- said, goodnaturedly, that he deserved a drive for his determination."

" $\Delta$ few years ago we left our household, in the old city of Cinterbury, in the charge of a man and his wife, who also undertook the care of a little Maltese spaniel, named 'Joey.'

" On one rough, blustering I)ecember night, when the inhabitants were in their profoundest slumbers, a tremendous 'bang' resounded through the house, awaking all its inmates, including Joey, just as the cathedral clock struck the midnight hour. Men and maids rushed hither and thither"; but no evident cause could be found for the alarm, every door and window being perfectly secure.

"After the first disturbance had subsided, Joey returned to the quietude of his own basket, with evident disgust at the unusual and, in his opinion, uncalled-for commotion, and refused to take any part in the search.

" At last he was forcibly put into the garden as an adranced guard, but lie flatly declined to move a step. All joined in upbraiding him. 'Joey was lazy!' 'Joey was a coward!' 'Joey Was no nse as a watch-dog !' And one of the servants expressed an opinion that he had been drugged by thieves, and that she had noticed a drowsiness on the preceding day. Next morning it was found that the large old-fashioned clock in the lobby did not strike the hour as usilal. The fict was, the weight which drove the striking part of the maclinery had broken arily from its cord, had fallen into the bottom of the case, and had produced the sound which had startled the liouse."

'The dog' evidently knew that no dangel was signified by the sound, and so leclined to trouble himsclf about the matter. 'This was the more remarkable, as he was the wariest and most suspicious of logs. He would never compose himself to sleep unless the sliutter's of the garden door were properly closed, and used to bark and growl at the door until it was made secure.

"In a former letter to you I mentioned my little dog Joey.

"The last summer of his life we left him as usual in the care of a man and his wife; but this time, unfortmnately for the dog, their son George, a boy of fifteen, was at home for his school liolidays. On our return, after an absence of some months, no little Joey welcomed us, and no one can tell how we missed his merry roice. Was Joey dead or ill? No; he was only slut up in a room up-stairs until after our arrival.

"Ve thought this to be rather a mysterious proceeding, and, on our entering the room, the poor little animal rushed to meet us, and then fell down powerless in a fit. The first time that George came into the room, Joey walked up to him, stared him in the face, and commenced a series of growls, looking at us every now and then as if to ask whether we understood him.

"Whenevel the boy entered the room this scene was repeated, and, even if we took Joey in our arms, he continued to growl, and secmed as if he thought that we ought to growl also. At the time we could not interpret lis meaning; but we afterward discovered that the boy had given him a blow on the head, which cansed him to have fits whenever excited, and at last caused his death. How plainly did he tell us who had injured him !"

In neither of these cases was instinct in the least concerned, the whole proceedings being dictated by reason, and reason alone. In the first instance the dog knew whence proceeded the sound which had alarmed the house, reasoned with himself that there was no cause for alarm, and, thongh he would have been in a paroxysm of batks if danger had really impended, he went back to his conch, and declined to tronble himsclf. In the second case the poor little creature, not possessing luman language, tried to make his friends muderstand, by a language of signs, that he had been injured by the boy. 'The langruage was singularly expressive, and would have been at once nuderstood, were it not llat lis mistress was herself so kind to animals that she 
nerer suspected that any one could be capable of doing the dog a willful injury.

I know sereral instances where domestic animals have discovered that there was something wrong in the arrangements of the house, and have called attention to it. There is a little dog bclonging to one of my friends, who one night becane rery importunate, pulling the skirt of his mistress's dress, and insisting on her returning down-stairs. She was rather alarmed; but the dog drew her to the greenhouse door, which he evidently meant to be opencd. On mlocking the door, she fonnd that she had forgotten to turn off the gas. 'The little dog had been accustomed to see the gas turned off before the family went to bed, and was too conservative to allow any change.

IIere is a similar example, which was cominunicated to me by a lady. "Did I tell you that my dog 'Tiny once found that the housemaid had forgotten to shut a closet door in a bedroom at the top of the house? He came to me, male me follow him, and showed me the open door.'”

Cats are not generally considered as houseguardians, but that they can act as such the following ancedote will show.

A lady had a very strong objection to "followers," and forbade her servants to receive a man into the house. One erening she was sitting in the drawing-room, when she heard the cat mewing and scratching at the door, as if for admittance. She opened the door; but the cat would not enter, and evidently wished to be followed down-stairs. She then desconded the stairs, and led her mistress into the litchen, where was the obnoxious "follower."

'I'his anecdote shors also that the animil must have becn able to understand human language, or otherwise she could not have known that her mistress had forbidden strange men to enter the house.

In the two following anecdotes the action of the dog can only be attributed to reason, and that of no mean character.

The first anecdote was sent to me by one of the principals in a well-known engineering firm.

"I once lost a sorereign in a bet which I madc that a wonderful little dog wonld not take a penny off a red-hot bar of iron. The dog belonged to an ironmonger at Knighton, Radnorshire. 'The dog was in the habit of scarching for pence purposely hidden in the shop, and, when found, taking them to a baker's shop and getting buns in exchange. He quite knew the right-sized bun, and used to keep his par on the penny until he got it.

"A bar was heated red-hot, and no sooner was the penuy laid on it than the dog, without the least hesitation, dashed at it. By some means which I could not see, bccause it was done so quickly, the dog knocked the penny off the bar, and then sat down quietly by it until the coin was cool. His look of perfect self-satisfaction was most absurd."

Some year's ago there was a dog at Margate whiich also knew the use of money. He used to beg for pence, and take them to a baker to be exchanged for biscuits, at a shop in the narrow, lilly lane which is pleased to assume the title of High Street. One day the baker, wishing to see how the dog would behave if he played the animal a practical joke, took his penny and gave him a burned biscuit. The next time the dog had a penny he took it to the baker as usual, showed it to him, and then went off to another baker who lived nearly opposite. This he afterward did invariably, showing the penny to the baker who had offended him, and then transferring his chstom to the rival on the opposite side of the narrow strect.

The whole of these proceedings were dictated by pure reason, and instinct had nothing to do with them. It was, in fact, doing on a small scalc precisely what the dog's master would have done on a large scale if a tradesman had taken his money and given lim a bad article for it. He wonld have withdrawn his custom from the offender, and given it to another man who he thought woukd serve him more honestly.

No one can say that instinct had any thing to do with these proceedings, the dog in each case dedncing a conclusion from premises, and dedncing them rightly. Had a child acted in the same manner, we should have thought it a very clever child; but we certainly should have attributed its action to reason, and not to instinct; and $I$ do not see that we have any right to attribute reason to the one and to deny it to the other.

We are familiar with many instances where dogs have tried to assist their fellow-creatures, whether human or belonging to their own kind.

'The following history of a suicide's dog was sent to me by a scotch lady, who takes a great interest in dogs.

"There is a cottage called 'Blaw-weary' on the farm of $\mathrm{C}$ - , the property of the Marquis of ' $\mathrm{T}$ - . 'This cottage is just on the other' side of our marcli-fence, about half a mile from our house on the west. 
"A shepherd lived in Blaw-weary some four year's ago (about 1868), and one day he and his collie dog went out early in the morning, according to their custom. At breakfast-time the dog returned alone, looking miserable, and would eat nothing. After renuaining a few minutes, he went out again; the man's wife, who was at lome, suspecting nothing. At clinner-time the dog came back again, also alone, and 'banged through the hoose,' as his mistress said.

"Presently he went out, and soon came in again, making piteous efiorts to attract attention. 'The assistant shepherd followed the dog, and was taken straight to a sinall clump of trees in the neighborhood, on one of which was hinging his master, quite dead. The poor dog wonld not allow any one to touch the body; and it was not until after he had been overpowered and led away that the corpse could be remored from the branch on which the wretched man had hanged limself."

Here we have a story which is exceedingly raluable, as it shows not only that the dog possessed reason, but is another proof that the reason will sometimes suddenly fail exactly when it seemed to hare been most successful. 'The poor animal had evidently witnessed his master's dying struggles, and, feeling himself unable to help, had gone to his house for assistance. Haring obtained that help, however, he conld not unclerstand that any one conld touch his belored master without intending to injure him. Many medical men have met with similar experien('es, the dog bringing assistance to his helpless master, and then not suffering any one to tonch lim.

Probably the animal felt that his master was lead, and that no one could restore him to life.

The following stories illnstrating the reasoning powers of dogs have been sent to me from scotland, where dog-natme seems to be better appreciated than in England.

"A retriever, named 'Bevis,' an old farorite of our own, was in the habit of going for' a walk before breakfast with my father. One morning it so happened that my fatler did not intend to take his usual walk. Beris soon became very impatient, and, seeing no signs of his master, he got upon a chair in the laall, took his master's hat off its peg, carried it up to his room, and then scratched at the door for admission. $\Lambda \mathrm{s}$ soon as the door was opened, in walked Beris, laid the hat at liis master's feet, and pushed his nose into his hand. It was entirely his own idea, as he had not even been taught to fetch a hat."
"Another dog of ours, a little Maltese poodle, named 'Pop,' was unusually full of tricks and odditics.

"He was fond of a game at hide and seek, a key being hidden for him, while he buried his face in the sofit-cushions. Sometimes he would be guilty of cheating, and would slyly peep out to see where the key was being hidden; but when reproached with the two simple words, 'Oh, Pop!' he would put down lis head again, and be very much ashamed of himself."

'The reader can compare with this story several anectotes of a similar character related in the chapter headed "Humor."

The following anecdote, which was sent by the same correspondent, affords a good example of wrong reasoning, i. e., drawing an incorrect conchusion from the prenises.

" A collie dog, named 'Moss,' belonging to a farmer, had excited the admiration of a drover who was helping the shepherd to bring home cattle to the farm. The drover asked to be allowed to borrow Moss for a few days, to help lim in getting some cattle from another market to Burntisland.

"The dog, being on friendly terms with the drover, went willingly, and gave his help in bringing the cattle on their journey. On their return, they had to pass the spot where the road to Burntisland branches off from that which led to lis own farm; Moss refused to go any farther on the Burntisland road. Not only this, but he would not allow the drover to take the cattle any further, and the man was at last obliged to let the dog deliver the cattle at his master's firm."

The process of reasoning is quite evident here. The $\log$ had always known that any property of which he had been placed in charge belonged to his master, and consequently brought the cattle to his master's farm. His reasoning was correct enough, but one of his premises was false.

Here is another example of reasoning in a dog. Several snccessive litters of puppies had been taken from their mother, a little terrier. When the next litter was expected, she left the house, and was not seen again for some time.

At last she returned, bringing with her in great pomp a whole retinue of fine healthy puppies. It appeared that she had hidden herself in a rabbitburrow, evidently knowing that, if she could only conceal her puppies until they were able to shift for themselves, no harm wonld come to them. The result proved that she liad been perfectly correct in her interpretation of her master's character. 
"One day my dog 'Bosco' wished to ascertain if the roast bcef still stood upon the passagetable at the dining-room door. He stood on lis hind legs, jumped np, but all in vain. So, after thinking a little, he ran a short way up-stairs, pushed his head through the banisters, looked down, and, after ascertaining that there was only pudding on the table, returned quietly to the parlor."

I have known a King Charles spaniel to act in very much the same way, except that in the latter case the dish which the dog wanted to inspect was on the dining-room table. After trying in vain to see what was on the table, he went ont of the room, went half-way up the stairs, and so took a survey of the table through the open doorway.

The following anecdote was sent to me by a gentleman resident in the neighborhood of the locality where the adventure occurred.

"There is a water-mill, called Maxwellhengl,, on the side of the road between Kelso and Teriot bridges. It is driven by a conduit of water from the Teriot immediately before its junction with the T'weed, and consists of two flats. The upper flat is on a level with the public road, and is called the 'Upper Mill,' while entrance to the lower flat, or 'Under Mill,' was reached by a cart-road descending from the highway.

"The first thing the miller did in the morning was to unchain the dog. He immediately placed limself on guard across the upper doorway while the miller proceeded with his work in the Under Mill. As soon as the miller had finished his work there, and removed to the Upper Mill, the dog, without being told, set off to the miller's honse, and in two journeys bronght his master's breakfast-namely, milk in a pitcher and porridge in a 'bicker,' tied up in a towel.

"On one occasion, when the Teviot and the 'Tweed were in flood, a little dog ventured incantiously into the 'Tweed, and was rapidly carried down the stream, struggling and yelping as it was hurricd along.

"It so happened that the miller's dog, while carrying his master's breakfast to him, saw the little dog in distress. He immediately put down his burden, turned, and set off at full gallop down the strean. When he had got well below the drowning dog, he sprang into the river, swam across, and so exactly had he calculated the rapidity of the river and his own speed, that he intercepted the little dog as it was being helplessly swept down the current, and brought it safely to land.

"When he got his burden safely on shore, the dog, instead of displaying the least affection for it, cuffed it first with one paw and then with the other, and returned to the spot where he had deposited his master's breakfast, and carried it to him as usual."

Ilow is it possible to refer the proceedings of this animal to mere instinct? Hlad a negro slave performed them, we should have used them (and with perfect justice) as arguments that so intellectunl and trustworthy a man onglit not to be the property of an irresponsible master.

'The whole behavior of the dog is exactly like that of a burly, kindly, and rugged bargee, possessed of cool judgment and rapid action, willing to risk his life for another, and then to make light of the whole business. I was for some years in charge of a water-side parish, and knew many a bargee who would have acted exactly in the same way if a child had fallen into the river. He would have got the child out at the risk of his own life, and then, instead of waiting for thanks, would have boxed its ears soundly, rated it for interrupting him in his work, and then have proceeded with his journey as if nothing had happened.

The man would have been held wortliy of the medal of the Royal Humane Society, and would probably have received it. The dog can receive no reward in this world: shall we say that he will receive none in the next?

The process of reasoning that took place in the dog's mind is as evident as if the brain had been that of a man and not of a dog. The animal exhibited self-denial, presence of mind, and forethought. Had he jnmped into the water at once, he could not have caught the little dog; but by galloping down the strenm, getting ahead of the drowning animal, and then stemming the current until it was swept within his reach, he made sure of his object ; and no man conld have acted better if he had tried to save a drowning child.

The following curious instance of reason joined with accumulation has been recently sent to me. I. know the dog, and an odd, eccentric little being he is.

"Property of erery description requires a certain amount of supervision, whether ' real or personal,' as the lawyers say, and has its attendant anxicties as well ats its attendant pleasures; bnt I nerer saw any animal so impressed with the responsibility as our present littie dog appears to be.

"Having been in onr possession all his little life-time, the items of his personal property hare gradually increased. At first he occupied the basket of his predecessor, which was taken up-stairs for him at night. After some time, another bas- 
ket was purchased for the drawing-room, the old une retaining its place up-stairs. New things are always firorites with children, and this at first was supposed to be the case with our little animal: he would not occupy the old basket at night, so the new one was bronght up at night and placel beside it. This was continued for a short time: when the old one was taken down, the new one only remaining up-stairs. 'This was not the right thing to do: he then refused to occupy the new one.

"I must confess to humoring his little peculiarities, so I fetched the old basket up, leaving both in the room. This was quite what he wanted, and gave evident satisfiction: he jumped into one, which he arranged comfortably, then performed the same operation in the other, and finally occupied both baskets at intervals during the night. He will now never compose himself at night until both baskets are in the room. One night I purposely remored lis dish of water; he missed it, satt up begging on the spot it always occupied, and great was his delight on its restoration, although he had no wish to drink. I have given him duplicate property, and placed his baskets, water-dishes, etc., at different parts of the room; he never fails to go the round and inspect his property before fixing himself for the niglit, and most amusing it is to wituess his anxiety until he has the whole of his goods under his own protection."

Here is an anecdote of important help rendered in a most unexpected manner. It was sent to me by the wife of the dog's owner.

"The late Lord M. had a very fine large black Newfoundland dog, called 'Neptune,' which used to be kept chained up in a conrt-yard outside the castle. Now Neptume was very fond of mutton and pork, and used to worry the sheep and pigs whenever he had a chance. II was consequently very seldom let loose or taken ont, unless they were going to ride in some out-of-the-way district. On one occasion, in the antumn of 18.56 , Lord M. and $\mathrm{Mr}$. H. were riding across country, accompanied by Neptune, when coming to a high lauk with a broad ditch on either side, Iord MI.'s horse refused to take it; so Iord M. dismounted, and, getting onto the bank, tried to lead him orer it; but while so standing on the bank a gust of wind blew his hat off, and in trying to sare it the bridle slipped from his hand, and the horse became loose.

"As quick as lightning, Neptune, who had apparently heen most interested in the endeavor to get the horse over, sprang after the hat, and, catching it, jumped with it onto the bank, drop- ped it at his master's feet, and dashed after the horse, which was trotting off; and, before Mr. II. could overtake it, he had scized the bridle with his teeth, and held on, checking it till Mr. II. came up and took the bridle from him, when he appeared to express his pleasure by little short barks and a variety of gambcls. What makes this a remarkable circumstance is that Neptune had never been broken in to fetch and carry, and lad never been used as a retriever, or was known or seen to do any thing of the sort before that occasion."

In the following example of the conduct of a $\mathrm{dog}$, it is impossible to see that instinct had any thing to do with his conduct, which was evidently prompted by reason.

"Thile a friend of mine was last week superintending his workmen in a wood, he observed his dog, a retriever, busily occupied in collecting mouthfuls of hay and withered grass, and carrying it all to one spot. On going to examine it, he found the deposit made was on a closely coiled hedgehog. The dog, having attained his evident purpose of rendering the spines harmless, proceeded to take up the heap with its contents, and then set off triumphantly toward home."

No human being could have acted in a more judicious manner; and had a man saved his fingers by enveloping the hedgehog in grass, he would not have felt particularly flattered if told that he had acted by instinct and not by reason.

A rather odd example of dog-reasoning occurred not long ago. A Newfoundland dog was walking with his mistresses, when he got into a quarrel with a costermonger's dog, fonglit him, conquered lim, and left him howling on the ground. Seeing, howerer, that the animal would be in the way of the ladies, he returned, took up the animal in lis mouth, and deposited him in the middle of the road, so as to allow them to pass without annoyance, and then retmrned to his nsual position.

We will now pass to other animals.

We are often accustomed to use the name of ass as a synonym for stupidity, whereas it is one of the most intelligent animals in the world. The Rev. C. Otway has the following remarks on the subject:

"I assert that if you were to make yourself acquainted with asses, you would find them clerer enough. I once purchascd an ass for the amusement of my children. I did not allow him to be cudgeled, and he got something better to graze upon than thistles. 
"Why, I found him more knare than fool; his very clererness was my plague. My ass, like the king's fool, proved the ablest animal about the place, and, like others, having more wit than good manners, he was forever, not only going, but leading other cattle into mischief. There was not a gate about the place but he would open it; there was not a fence that he would not climb. Too often he awoke me of a summer's morning, braying with sheer wantonness in the middle of my field of wheat. I was obliged to part with him, and get a pony, merely because he was too cumning to be kept."

A correspondent of Land and Water gives an interesting account of a similar mode of proceeding on the part of two long-horned cows. The door of the hay-chamber opened outward, and was fastened by a latch lifted by the finger thrust through a hole in the door. The cows had seen this done, and, if left alone, would invariably open the door by inserting the tip of a horn into the finger-hole, lifting the latch, and then drawing the door toward them. He also describes the mode in which a cat opened a kitchen door, by jumping up and hanging on the handle of the latch.

Dr. Bell has recorded almost identical habits both of the horse and the cow, and I have heard similar stories in many places.

As if to illustrate this point still further, I have just received an account of a cow which could not be kept in the field, because she was in the habit of lifting the latch with her horn and then pushing the gate open.

The same correspondent mentions a horse which was accustomed to pump water for himself. The pump was in a corner of the horsebox in which the horse was shut for the night, and the coachman nsed to be puzzled at the fact that when he came in the morning the end of the stable was always an inch or so deep in water. At last he suspected that the horse might have been the delinquent, and so fastened him up without giving him any water, and watched him unobserved when let loose in the morning. The animal went at ouce to the pump, took the handle in his teeth, worked it up and down, and, when the water was in full flow, placed his mouth under the spout to drink. He conld not endure being watched while pumping, and, if he saw any one observing him, would rush at him with open mouth in order to scare him array.

The mule, like the ass, is popularly thought to be a stupid and stubborn creature, and yet there are few animals more intelligent in their way.
I can not resist relating one or two anecdotes, which are told by J. Froebel, in his work on South America. The mule, it appesrs, is a most difficult animal to manage, on account of its cunning. Force is of no use, and the Mexican mule-drivers pride themselves in their skill in managing the animals. At the end of the day's journey, the mules are unharnessed and allowed to go free, and are captured by the lasso when they are to be again harnessed. Some mules are so cunning, however, that even the experienced muleteers can scarcely capture them. . Some of them assemble in a compact circle, with their heads all pressed together, so as to prevent the noose from settling on their necks, while others push their heads under the wagons or between the wheels. Others, still more cunning, stand still, and as the lasso rushes toward them, merely step aside and let it pass.

One mule, a white one, succeeded in baflling the attempts of the drivers throughout the whole of a long journey. As soon as the harness-time approached, it ran off for half a mile, and there stood until the whole train of wagons was in motion, when it quietly joined its companions. On one or two occasions it was captured by a couple of men on horseback; but it led them such a chase, wasted so much time, and fatigued the horses so much, that it got its own way and had a mere journey of pleasure, while all its companions were hard at work.

Another mule, which belonged to a convent, was equally averse to work. There were six mules, each being worked on one day of the week in regular order. This mule knew its own day perfectly well, and on that morning it always tried to keep the servants out of the yard by backing against the door.

The following accomt of a horse was sent to me by a clergyman:

"I had long entertained the idea of sending you a brief account of an instance of reason which occurred to my own knowledge, and indeed at our own door.

"A neighbor possessed a young foal, which, with his mother, used to pass our house daily, early in the morning, during our breakfast-time, and had a habit of straying upon a piece of waste gromnd which then occupied its front, but has since been inclosed and formed into a front garden. My daughter, who is extremely partial to horses, used to run out and offer the little animal a piece of bread.

"This went on regularly, until at last, when he was between two and three years old, he would not wait for the bread, but nsed to go to the door. plant his fore feet on the steps, so as to gain suf- 
ficient elevation, and then lift the knocker with his nose, afterward waiting for the expected morsel.

"Had I been a rich man, I would have bonght him at alınost any price; for his mother was a well-bred mare, and he promised to be a very useful roadster."

Here we have the two qualities of memory and reasoning displayed in a most unmistakable character. Indeed, if we suppose that a dumb man had acted as the horse did, we should have been disposed to marvel at the way in which human reason conld communicate ideas without the aid of speech. In this case, the memory of the animal enabled him to expect his daily dole of bread, and his reason-not his instinct - taught him that, when the knocker was sounded, some one came to the door. It is evident that the horse had seen the knocker used, had noted the result, and had followed the example, using, of course, his nose in lieu of a hanci.

Perhaps there are few of us who have possessed pet cats who have not seen the animals perform very similar feats. Although too small to reach a knocker or a latch, many a cat has been seen to knock at the door and to open it for herself, merely by junping and striking the object with her paw.

Somctimes, when a door must be opened by means of a knob instead of a latch, the animal knows perfectly well that it is physically incapable of turning the handle, and therefore does not try to do so. But it will always find some way of intimating its wish to have the door opened, and will ask, as plainly as if it possessed speech, some human being to perform the task of which it feels itself incapable.

Some few years ago, Professor Cope related the proceedings of a tame monkey which he possessed-one of the common Capuchin monkeys.

The animal was kept in a cage, or rather was supposed to be kept in it, for he had a strong objection to confinement, and was sure to break loose sooner or later. He always directed his attention to the hinges, and no matter low firmly they were fixed, he was sure before long to extract the staples, pull ont the nails, and so open the door at the hinges and not at the latch.

Finding that the cage could not loold him, his master laad him confined by a strap fastened around his waist, after the manner of monkeys. 'The strilp proved to be of no more use than the cage, for the crafty animal soon contrived to open it. This he did by the ingenious expedient of picking ont the threads ly which the strap was sewn to the buckles, and so rendering the fastenings useless.

Then he was replaced in the cage and carefully watched. IIaving rid himself of the strap, he thonght that he miglit as well turn it to some useful purpose. So, having perceived that somc food had fallen ont of his reach, he took one end of the strap in his paw, flung the other orer the morsel of food, and so drew it toward him. In this feat he displayed great accuracy of aim, seldom missing the object which he wanted.

Once or twice, when he had to make a longer throw than nsual, he loosened his hold of the strap. The first time that this happened, some one handed him the poker. He took it, drew the strap toward him, and resumed its use as before.

Now I should think that no reasonable reader could deny that every one of these acts was prompted by reason, which, so far from being even aided by instinct, was acting in direct opposition to it. The instinct of an animal when confined or tethered in any way is to break loose by main strength, and the instinct of the monkey wonld have impelled him to force his way through the bars of the cage or to strain at the strap until he broke it. His reason, however, tanght him to look for the weak part in both cage and strap, and, laving found it, to work at that part alone until he succeeded in his object.

How was it possible for instinct to teach him that the hinges were the weak part of his cage. and that, if he conld only manage to draw the staples or nails, the door would open and he would be free? How could instinct teach him that the stitches of the strap-bnckles were to the strap what the staples and nails were to the hinges, and that, if he could pick ont the threads, the fastenings of the strap wonld be rendered useless: Neither could instinct teach him to use the strap in the light of a lasso, or to employ the poker in regaining his lost weapon.

Baron 'I'renck himself conld not have displayed more ingennity in discovering the weak parts of his prison and bonds than did this little monkey. nor conld he have shown more patience and perseverance in working at them. Indeed, there are many human beings who would not have been half as sensible. 


\title{
CHAPTER IV.
}

\author{
REASON-(concluded).
}

Enjoyment of Work by Animals._The Elephant and the Dray-horse._The Miners' Horse. - "Jock" at his Work. -The New Forest Horses. -The Carrier's Horze and his Master._Sir Hope Grant's Story of a Wounded Horse.-An Elephant in a Quicksand: Mode of Extrication.-The Cat and the Lobster.-Ingenuity of Rats._Pigs versus Rats._Crows versus Pheasants.-The Ravens and the Bird-traps.-Robbing the Railways.-My Raven "Grip" and his Run.-IIistory of a Parrot.-A Self-tamed Red-breast, with his Well-educated Family; Death of the Father and Friendship of the Widow and Children.-The Cat "Patch" and the Monse._- "Pret"s" Monse-chase._Reason and Power of Combination in the Rat.-The Fox and the Grouse.-A Dog-strategist in Battle.

Sometnes animals take a pleasure in their work, and do it without needing any superrision. Elephants, as is well known, when once shown what their work is, will go on with it while their drivers are elsewhere engaged. Dray-horses may often be seen exercising their reasoning powers while drawing casks out of the cellars. 'The drayman in the cellar makes the rope fast, and calls to the horse. The animal understands the signal, and goes off with the rope, keeping an eye on the cellar-cloor. As soon as he las bronght the cask safely to ground, he stojs, backs to allow the rope to be remored, and then goes back for another cask. 'This may be seen almost any day in London.

Mr. J. Nelson Smith tells me that, while examining one of the American mines, he saw a horse which was doing his work without the assistance of any driver. As soon as his cart was filled with ore, one of the miners gave his signal, and the animal went off to the spot where his load was to be "dumped," waited until the cart was unloaded, and then returned for another load. The strangest point in his conduct was that he had to take a certain number of loads daily, and knew when his task was finished as well as did any of the men. Mr. Smith happened to be present at the time when he deposited his last load for the day, and, on seeing him trot off quickly in another direction, was told that he knew his work to be finished, and that he was going home, where he would meet a kind reception from his mistress.

A lady has sent me the following account of a horse of her own:

"We have an old horse named 'Jock,' a rery wise beast, lut cross-tempered. IIe fell when drawing Lord L.'s carriage, and, in con- sequence of his broken knees, was purchased cheaply.

"He knows his work so well that the man who accompanies the cart does not need to lead or drive lim, Jock preferring to do his own work in his own way. I have often seen him take the cart to the exact spot intended, turn it round himself, and wait to have it loaded. When the cart is filled, he takes it to the spot where it is needed, and, after it is unlonded, brings it back again. He evidently enjoys the work, and seems to take a pride in it."

IIorses will really do a wonderful amount of work withont assistance, if properly managed, and will sometimes do so even when employed by owners who would scarcely be thought capable of acting as teachers. In the New Forest, a place tenanted by a race of human beings almost independent of their fellow-beings, and holding their laws and customs in equal scorn, I have often, when driving along one of the roads, been obliged to turn off the road, and to manœurre both horse and vehicle into the underwood, in order to allow a train of woodcarts to pass. These wagons are constructed in cool defiance of the Act which prohibits more than a certain widtl between the wheels, so that a cart will occupy the full breadth of the road. No one drove the horses; but on each cart lay one or two men, utterly intoxicated, having managed to scramble into their vehicles under the knowledge that their horses would take them safely to their homes.

I know of a carrier's horse which acts in a similar manner, though not for a similar reason. The man has to make a night journey, beginning about midnight and ending about six A.M. 'The driver has such perfect confidence 
in his horse that he composes himself to sleep as soon as he las started, knowing that the animal will stop at the right house. Sometimes he is asleep when the jonney is over. 'The horse, after looking aronnd at his mister, and seeing that the stopping of the cart lias not aroused lim, hegins to stamp on the ground, and rattles lis harness nutil lie awakes.

General Sir Hope Grant, in his diary of the "Incidents in the Sepoy Wir," narrates a most remirkable instance of reason on the part of a hor:e :

During the war, aftel the Secundra Bagh had been taken by our troops, the Enropeans were aroused by musketry from some nuseen ynarter. Sir Hope's nepliew then went to the place, grave his horse to a Sikh soldier to hold, and went inside, when he found that some of the rebel sepoys were on the top of the wall. Finding themselves diseorered, the men, with the curinus indifference to life that eharacterizes their race, canie down and were shot.

Suddeuly a loud explosion was heard. An awkward soldier had fired into a barrel of powder, which, together with a quantity of loose powder that was scattered abont, exploded, and did much damage. 'The non-commissioned officer' in charge of the Sikh party was so sererely burned that he died a few days afterward; and several were killed, among whom was the man who was holding the horse.

'The animal was so scolched that he had to he shot. It so happened that the man to whom this task was intrusted aimed badly, and, instead of killing the poor creature, only inflicted a serele wound in the head.

'The horse broke away, galloped directly toward a picket of the enemy, dashed through them in spite of their fire, and was soon ont of sight. Next morning it was discovered that the horse had made his way five miles in a straight line, and had gone direct to the siekliorse stables of the 9 th Lancers. In fact, he had acted exactly as a wounded soldier wonld have done-gone to the hospital and reported himself sick.

I wish I conld gire a more pleasing end to the story, but the poor horse was found to be so fearfully injured that the inost hmmane comrse was to destroy him at once.

A rery similar exercise of reason was displayed by a little Welsh pony.

At hiliyll there are many of these animals let for tempolily hire, and among them was one that was ridden by a young lady in delicate $\mathrm{C}$ health, who was obliged to keep to a very slow pace. One day in the year 1873 the pony was seen dashing along at full gallop, nutil it reached a blacksmith's forge, into which it went witlunt a pause, carying its unwilling rider with it.

The astonished blacksmith tried to lead the animal ont of the forge, bnt it resisted this strongly, and he found that it had east a shoe, which it wished to lave replaced. Now in this. instance, as in many others, reason conquered instinet. The instinctive feelings of a horse are strongly opposed to the operation of shoeingr, and some liorses ean scareely erer be made to stand still under the process. It is very natural that they shonld not like their feet to be hammered and filed and scraped and scorched, and it therefore requires a rery determined exercise of reason to induee an animal voluntarily to counteraet its own instincts.

In the following account of an elephant's ingemnity in extricating himself from a quicksand, instinet is shown to have no part. The story was sent to me by the gentleman who witnessed the oecurrence, and was one of the party.

"It was at the close of a "pig-sticking" meet on a large island in the Ganges, opposite Cawnpore, in June, 1873, that an event oceurred which excited my admiration. With three friends I had been riding hard all the afternoon, and, feeling very tired, we deternined to go home on the elephant.

"We had traveled some way, and were nearing the river, when one of ns noticed that the ground looked rather unsafe, and that the elephant seemed to become uneasy. So we all decicled to dismount and walk to the river, previonsly instrncting the mahout to take the elephant by a short eircuit, so as to aroid the soft ground. The man, however, evidently considered that he knew bettel than we did; and we therefore went straight on, not thinking of looking around.

" We had not proceeded far when we heard the elephant trumpeting (a well-known signal of distress or anger), and on looking around saw that the poor beast was in a quicksand, and that the mahout had dismounted and was making the best of his way ont of reach of the animal. I may here mention that to be on an elephant's biek or within his reach nnder snch circumstances is certain death: he is sure to take hold of a man and place him under his feet, so anxious is he to get something solid to stand npon.

"We were then abont fifty yards from the river, and it was rapilly getting dark. 'I'lie ele- 
phant was making frantic efforts to escape ont of his difficulties, and the ground heaved all around him. How to help him we did not know; for he was sinking deeper and deeper, and go near him we dared not.

"As good fortune would have it, there happened to be at hand a number of large planks which had been left by some villagers. We went as near the elephant as we dared, and threw the planks within his reach. 'The clever animal seized them in his trunk, drew them to him, and laid them one upon the other in front of him. When he thought that he had enough, with one gigantic effort he got his fore legs out of the quicksand, and in a short time he had managed to extricate himself, and was standing safely on the planks, though trembling all over.

"He had still some fifty yards to go before he conld reach the river, and the intelligent beast never mored a step until he got a plank and placed it in front of him. He thins moved on, step by step, on successive planks, nntil he reached the river. The mahout then remounted him, and he crossed the Ganges in safety. This wils $n$ small relief to our feelings; for the loss of the elephant would not only have been a very costly business, but the mode of his death would have been inexpressibly painful."

The following account of reasoning in a cat was communicated to me by its mistress, Lady E., whom I have known for many years. 'The animal evidently felt surprised that such a thing as an empty plate should be allowed upon a breakfist-table, and so, in her own way, showed her mistress" how a plate ought to be filled.

"Our breakfast-room had bow-windows, and the houses were very near each other.

"() ne morning, when the windows of both houses were open, our younger cat, Tiny, disappeared into our neighbor's window, and a few minutes after rished back into our room, and, leaping upon the breakfast-table with a lobster in her mouth, held it over an empty plate. She evidently only wished us to see it, as she would not allow any one to touch it, and darting ont of the window again, with the lobster still in her mouth, she replaced it upon the table without taking any, and came back to our room.

"The lobster was returned so carefully that our neighbors assured us they should not have known it had been touched."

The same lady has sent me several anecdotes of this same cat and her mother "Rosie," all of which are interesting, and serve admirably to illustrate the subject of this work.
Sereral good instances of reasoning as displayed by rats are given in Hardwicke's Science Gossip for July, 1871. A number of rats hard got into a basket of grapes, and devonred a considerable part of the contents. 'The man who discovered them replaced the basket, in hopes that they would again risit it and be canght; but the wary animals never again came to the basket in which they had been detected.

They were so mumerous and so bold that they used to come and pick up the crumbs from between the men's feet as they sat at meals. "Wishing for" a shot at some of them, I dropped a few gratins of maize on the gromnd, and took up my position, gun in hand. Soon one rat bounded across the space as if in great alirm; but no rat tonched a grain of the corn, which was exposed for sereral days and nights, being at last crished and lost by the passing of feet and goods.

"Rats were numerous in the pigsties, and ate with the pigs, one of which I turned out of her sty, and contrived a trap-door to close the trongh by pulling a cord. I baited the trongh with ground maize, of which they are very fond; but neither by day nor by night would a rat renture there as long as the pig was excluded. Returning the pig to the sty, the rats also returned."

I know of a similar case in which the rats were so many and so bold that they forced themselves into the troughs at feeding-time, would not be driven away, and consumed no small amount of the food which ought to have gone to the pigs. The owner of the pigs then laid a gun so as to rake the trongh, turned out the pigs, and had the trongh filled as usual. Not a rat would make its appearance; and at last the pigs iwere put back, when the rats came trooping in as numerons and as bold as ever.

Now, in these cases, the rats could not have known the precise danger which menaced them; but they saw that something umusual had happened, and therefore inferred that it would be the safer plan to keep ont of the way until the ordinary conditions were restored.

Many birds display great reasoning powers, and act in a way that would do credit to any liuman being. From the many anecdotes which have been placed at my disposal I select only a few, none of which have as yet been published.

In places where pheasants are preserved it is customary to give them their food in such a way that other birds can not get at it. This is done by placing it in a feeding-box, which is closed by a lid, communicating by a lever with a perch. 
The weight of the lid is so adjusted that when a pheasint stands on the perch the lid is raised, and the bird can get at the food. The pheasants soon learn the object of the perch, for, when these boxes are first introduced, $a$ few beans are laid on the outside of the lid. The bird gets on the perch in order to reach them, and so exposes the stores of food in the box.

Such an arrangement is made at Mountquharrie, Cupar, Fife; and one day a gentleman was watching the pheasants and their boxes on the lawn just before the house, and saw a crow also watching them. Presently the crow flew to one of the boxes, settled upon the perch, and expected the box to open. 'The bird, howerer, being much lighter than a pheasant, was unable to lift the lid in spite of all its efforts. After several ineffectual attempts it flew off to a tree where there was another crow, and a grand jabbering eisued. The two crows then flew to the feeding-box, both settled on the perch, and their united weight was sufficient to raise the lid.

It is inpossible to attribute this proceeding to any thing but reason. Instinct is wholly out of the question in such a case as this. The bird first watches the pheasants, and learns that by settling on a certain perch the box is opened and the contents attainable. It then proceeds to follow the example of the pheasants, judging that the same result would follow. Finding that, although it acted exactly as did the pheasant, the lid was not raised, it set itself to discover the cause of failure, and, as we have seen, succeeded in so doing. Having reflected that the pheasant could lift the lid on account of its superior weight, the bird calculated that two crows might be equal in weight to one pheasant. So it goes off to find a comrade, explains the state of things in its own bird language, and the two then co-operate in producing the desired effect. No human being could reason more correctly, or reduce its theory to action more successfully.

That the raven can act in a similar manner is shown by an anecdote sent by Mr. R. Ball to Mr. Thompson, and quoted in his "Natural IIistory of Ireland:"

"When I was a boy at school, a tame raven was very attentive in watching our cribs or birdtraps, and when a bird was taken he endearored to eatch it by turning up the crib; but in so doing the bird always escaped, as he conld not let go the crib in time to scize it. After severul vain attempts of this kind, the raven, seeing another bird ciulught, instead of going at once to the crib, went to another tame raven and induced it to accompany him, when the one lifted up the crib and the other bore the poor captive off in triumph."

Crows are wonderfully sagacious, and seem to notice every thing.

A gentleman, one of the principals in a wellknown engineering firm, tells me that the way in which crows rob the railway-boxes of the grease is quite notorious among those who are connected with the lines.

As my readers are probably aware, each of the wheels has an iron box over the axle in order to contain the grease which lubricates the wheels. Cocoanut oil is used for this purpose, as it is solid at moderate temperatures, and only melts and sinks mpon the axle when the latter is heated by orer-friction. Indeed, if cocoa-nut oil had not been discovered, it is difficult to imagine how railways could be carried on. The boxes are closed with spring lids, and we have most of us seen the porter, armed with a little pail of cocoa-nut oil and a wooden spatula, open the box with the spatnla, fill it with the yellow grease, and slap down the lid upon the box, where it is kept in position by a spring. This is absolutely necessary in order to prerent the oil from being mixed with the cinders ejected from the engine and the particles of earth driven up by the wheels.

Now it happens that crows value the cocoanut oil as much as we do, but for a different reason. They consider it to be a great dainty, and so, when a train is standing still on a siding and no one near, the crows flock to it, substitute their strong beaks for the porter's wooden spatula, pry up the spring lids, and help themselves to the yellow oil.

It is evident that they must act from reason and not from instinct. Some of them had seen the porters lifting up the lids, and had followed their example. All the crow tribe are wonderfully expert in the use of their beaks, and the dainty manner in which a raven, a magpie, or a jackdaw will turn orer, twist, and display with its beak any object that may excite its cnriosity could scarcely be surpassed if the bird possessed a hand iustead of a beak.

My raven, "Grip," who unfortunately died from eating too much linen, had astonishing delicacy in the touch of his great iron beak. If I tied a knot in a piece of string and left it within his reach, he was sure to untie it, and then walk about triumphantly with one end of the string in his beak. He had a large wooden cage made from a chest, and faced with strong iron bars. A hole was cut in the end of the box, leading to a large "rmm," inclosed with wire netting.

There was not a spot at which the netting had been joined that had not been lested by Grip's 
beak, and more than once I have just been in her acquirements. She sang 'Cheer boys, cheer, time to prevent his escape. He alway's resented rery plainly, and could dance. If any stranger my interference, and used to seize in his beak the went into the kitchen, and no one was there, wire with which I was making the defect good, Polly called ont, 'Somebody's wanted ;' and she and try to pull it out of my hands. At last he has more than once startled people by saying, gave up the wire net, and tumed his attention to the bars of the cage. They were much too strong for him to bend, but he delibcrately set to work at one of the central bars, and dug away the wood in which it was set mutil he had loosened it at the bottom. Fortunately I was just in time to see him pulling at the batr, or there would have been an escaped raven and frightful havoc among the poultry kept by my next-door neighbor.

Directly Grip saw me he set up a great squall, and did his best to get out the bar before I could reach him. I at once sent for wire and pliers, and at last succeeded in connecting the whole of the hars with cross-wire, so that muless all the bars were dug ont both abore and below they would hold their place.

Grip was horribly angry during the time, and tried to annoy me as much as possible by striking at my fingers throngh the bars, and trying to pull away the wire. Once he did seize the pliers, and I was obliged to bring on the scene my dog "Bosco," whom Grip hated beyond conception, before I could induce him to drop the pliers. Bosco's presence, howerer, elicited a scream of rage; and as the pliers fell from his beak, I secured possession of them. He afterward tested the wires from end to end, tried to undo every knot, and, finding himsclf batfled, gave up the whole business as a bad job.

IIere are some parrot anecdotes, all perfectly original :

"A parrot, belonging to one of our serrants, very soon knew us by nane, and could distingnish the tread of its farorites, showing its joy by ruffling its feathers and making an odd noise in the throat. 'Polly' was very tame, and was sometimes allowed to walk abont the house, alwars ammonncing its arrival in a room by 'Polly going a-walking.' In hot weather she enjoycd having water loured over her, and when satisfied would say, 'That's enough,'

"She need to tease our large dog by whistling londly, and calling him 'Bran! Bran!' on which lie ran in and looked around, and on the cook coming in, Polly would say reprovingly, 'Go back, Bran, go hack;' out went Bran, and by and by, when the cook's hack was turned, the same scene was acted over again, mntil Bran grew wiser and neglected the call.

"Polly was a very accomplished bird, and, when quite alone, could be heard going through

"We used to go in and see Polly before we went to bed, and she always said 'Good-night' several times, each time in a different tone of voice. 'She called mamma 'my lear' until told that it was not respectful, after which she always said 'ma'am.' 'The remarks this bird made were so apposite that it really seemed at times as if it mderstood what was going on."

I know a parrot, or, correctly speaking, a ringed parrakeet, that acts, as the serrants say, "just like a Christian." If told to call the cat, she will sometimes mew loudly, and sometimes call the cat by its name, "Winks," which is an abbreviation of Tiddlywinks. She makes the room ring again with the name, her voice is so powerful. Somctimes she will play at hide and seek; and if her mistress gets under the table, Polly trarerses it in all directions, and, not seeing her, knocks violently on the table with her beak, in order to induce her mistress to come out of her liding-place.

In the following history of a self-tamed redbreast, we shall see that instinct plays but a rery small part, almost the wholc of the bird's proceedings, as well as those of his family, being instigated by pure reason without any admixture of instinct. To the Jady who sent me the anecdote I am indebted for sereral of my most interesting accounts of animal life. She does not wish her name to be mentioned, but it is well known throughout the whole literary world:

"In the years 1864 and 1865 a robin made itself at home in my dining-room, always coming to the window and tapping to have it opened at breakfast-time. When he came in, he-sliared my oatmcal porridge with me, seating himself on the elge of the cup and picking ont such grains as caught his fancy. He then picked up crumbs of bread or tonst, and, when he had satisfied himsclf, he sat on the back of my chair and sang, or somctimes betook himself to the top of a large screen. When he wished the wiudow to be opened for him, he used to make a peculiar little noise, unlike any sound I ever heard from a bird-not loud, but very much like articulate language.

"As you may fancy, he was a great favorite with every one in the house. If the day were very cold, he always seated limself on the edge of the fender as soon as he was let in, puffing out his feathers to receive the heat, and, when he 
found that he was warm enough, he came to his breakfast.

" J) uring the summer of $186 t$ lie came occasionally to the windor, but seldom cane in, and then only for a moment, though lie would sometimes follow ne out of doors. In the winter of 1561-5 he again established hinself in the lionse, on his own familiar terms, and became even a greater pet than ever. He then began to prefer the bitter-cooler to the porridge-cup for his breakfust, but I never allowed him to take too mucl. He almost lived in the house, sometimes remaining all night wlien the weather was bad.

"When summer came around again, he appeared one day at the window with his wife and children, who sat on the ledge of the window while he entercd and took food out to them. It then came out that of late he had often been detected in carrying off food from the peacock's bowl which I kept in the dining-room; this food he lad doubtless carried to his lady in her nest: the dining-room window, being mostly open in summer, gave him access to the bowl.

"A siste"-in-law of mine and her daughters came to stay with me just then, and to see the little redbreasts get their breakfast daily from their papa was one of our morning's amusements.

"But, alas! one day he came looking rery ill, with his feathers puffed out, and looking twice his natural size. I observed that he swallowed large lumps of buttel himself while heljing his young ones. This went on for some days, and at last he did not make his appearance at all; lis wife and fumily came without him, and then we knew that he must be dead. There was general mourning fol" poor 'Bobby' in the house. I have never had so tame a redbreast before or since, though his wife and children, who seemed to miss him much, still continued to receive their dole at the window.

"I heard a still more wonderful story about a robin from my sister-in-law, who knew the lady to whom the bird belonged. She had made it so tame that it used to fly after her carriage; and when she went in the winter to spend a few days with a friend who lived several miles from lier lolise, the bird followed her. On the following morning, when she opened the window according to custom and called the robin, he at once entered the room and perched on her finger.

"Was not this very like reason? It certainly was a combination of ideas. The bird had followed his mistress to a strange place, slept there, and came at her call, trusting to her for his breakfist. Mr sister-in-law was staring at the house at the time, and witnessed the circumstance."
In the former of tliese two eases, reason taught the bird to conquer its instinct, which teaches it to fear man and avoid him. The bird soon fomnd that he was being kindly treated, and, reasoning upon such premises, came to the conchnsion that he would be treated in the same manner for the future. Then, that birds must have a language in which to express their ideas is evident from the fact that his wife and family accompanied him to the house, and waited outside while he went and brought out food for them. 'The reason why they did not enter the house is erident to all who know the habits of the redbreast. It is one of the most jealous of birds, and never will allow another bird to enter the place of which it has pleased him to consider himself the owner. There can be little doubt but that he had previously forbidden his family to enter the louse where he felt himself a privileged inmate.

The capability of cats for opening doors, ringing bells, etc., is perfectly well known. There was a cat named "Patch" who was a great adepe in these arts. One evening she came out of a bedroom in a state of great excitcment as the occupant went in, mewed and fidgeted about ; went up to an unlighted candle, though there was a fire in the room, back to the lady and then again to the candle, and would not be contented until it was lighted. 'Then she drew particular attention to the window-curtain, reaching 11]' with her paw as far as she could, and touching it. The curtain being shaken, out dropped a mouse, which Patch immediately seized and carried off. She had, probably, previously brought it into the room, as she was in the habit of doing so with her prey, and on two or three occasions dead mice were found deposited in the bed.

My own cat, "Pret," has often behaved in a similar manner, and has brought me to help him in getting at a mouse which had hidden itself iu some spot where he could not reach it.

I might multiply anecdotes to an indefinite extent, but have thouglit it better to take a comparative few, nearly all of which have been as yet umpublished. The reader will see that in no one of these cases does instinct play any part, and that in the generality of them the reasoning powers of the animal have overcome its natural instincts.

Here is an example of reason and the power of combination in the lat. The writer was at the time resident in Liverpool:

"In my garden there is a conservatory, along the roof of which is trained a rine, on which the fruit would not ripen for the last few years, so I 
had the rine inclosed in a glass frame in the hope that, the heat being confined, the grapes would ripen better than when exposed to the cold night air. 'This plan being snccessful, I had this year a plentiful crop of large-sized bunclies of grapes. These, howerer, began to disappear very quickly as soon as ripe, but not bunch by bunch as wonld be done by thieves, but only the ripest grapes of each bunch were taken.

"At first, I thought that some of the boys working in the garden had been helping themselves; bnt all denied it, and no one had seen them near the glass house. 'Then I sealed np the door of the corering, but still the fruit disappeared. So. I told the gardener to cut all the grood fruit and take it into the house when I returned home in the erening; after giving the order, the gardener came in with gleeful visage and said, 'I've got the thieves, sir,' and told his tale in that roundabout way which men in his condition love, of which the following is the condensed description :

" "When lying on my back for rest after" cutting a lot of branches, I heard a scuffling sort of sound, and looked around and saw five or six large brown rats come into the frame; they then jumped up at the lowest hanging branches and managed to knock down two or three grapes, which they proceeded to eat like a squirrel, sitting $11 p$ on their hind legs and holding the fruit in their front paws.

" 'Soon after, a large female, followed by four young ones, came in; and the old one ran up the vine and bit off one of the ripest bunches, which fell down to the expecting young ones below, who fastened on it and began to eat. 'Then,' concluded the old man, 'I could not keep my langh any longer, but shouted out, which sent them all head over heels out, as if a dog were after them."

A curious instance of reason in the fox has been furnished to me by an eye-witness:

"I will now tell you a story of a fox. Some years ago, when I lived in a lonely but beantiful part of the Lammermoors, there came a dreadful snow-storm. All nature was white for miles, as if wrapped in a winding-sheet, and birds and beasts were put to strange shifts for food.

"I was talking with one of my shepherds, when far away on the opposite side, and on the top of what is here called a cleugh or hollow, I espied a small dark object. It was the only one in the rast expanse of snow, and it appeared to me to be moving. I pointed it out to the shepherd, who said that it was a tuft of heather, from which the snow had drifted. I watched it more carefully, and, feeling sure that it really did move, I went into the house for my gun, and told the shepherd to accompany me.

"Slowly we plodded our weary way through snow up to our waists in some places; and when we arrived within a few lundred yards of the mysterious object, it was revealed in the shape of a crafty fox, who deliberately walked away, every now and then stopping to look at us.

"It was evident what he had been doing. $\mathrm{He}$ had coiled limself round so as to look like a bunch of heather (and done it so well that he had even deceived the practiced eyes of the shepherd), and thus decoyed the hungry grouse near enough to seize them. 'That he had succeeded was plain, from the feathers and other remains of sereral birds which lay near the spot where we first saw him. Foxie is a rare purreyor, and nothing can beat him."

A rather amusing instance of reason in a dog has been narrated to me. The animal was a Newfoundland, and of a quiet disposition. There was, however, a much larger and quarrelsome dog of the same kind, who was frequently meeting "Lion," and taking every opportunity of molesting him.

One day the big dog met him, and evidently bent upon a fight. Wherempon Lion, knowing that he was no match for his antagonist without some aid, ran off to a neighlboring manure-heap, and rolled himself orer and over in it, until he was completely corered. He then went back to his enemy, challenged lim, fonglit lim and beat him thoronghly, and after that victory the big dog always gave Lion a wide bertl. 


\section{CHAPTER V.}

\section{LANGUAGE [OF ANIMALS].}

Ideas Useless unless they can be Transmitted.-Language the Means of Transmission._Varions Kinds of Language. - The Spoken Language, or Language of Words. - The Gestme-Language, or Languagre of Signs.-The Languagre of the Eye, or a Direct Transmission of Ideas without the Aid of Words or Gestures. - Language of Insects. - The Wasps at my Breakfust - table: a Messenger and Result of the Message. - Language among the Ants: Severity of their Mikitary Discipline. - Ant-Undertakers.-A Summary Exccution.-Power of Combination and Submission to a Single Leader.-Comparison with the Egyptian and Assyrian Laborers. -Language among Dogs.-A Tempter and his Victim.-Language and Combination amolig Dogs. - Ditto among Wolves. - A Specific and a Universal Language among Animals.-Language aud Combination among Baboons.-Monkeys and the Charge through the Mud.-Division of Labor between Dogs. - Mutual Arrangements between a Dog and a Cat.-Rook Parliament seen by a Lady in England. -Ditto by a Geutleman in India._Ditto by a Gentleman in Cornwall.-A Thrush Parliament Discussing the Fruit Question. - Martins Sitting in Judgment on a Sparrow, and Killing Him._"Beau" and his Rescuer._A Quarrel and a Pcacemaker.-The Goose, the Ducklings, and the IIen.

The possession of ideas, whether they be right or wrong, infers more or less reason in those be$\sqrt{\text { ing }}$ ings who possess them. 'I'hose ideas wonld be absolntely unknown withont some means of transmitting them, and such means we call by the name of Linnguinge.

There are several kinds and degrees of language known to ourselves. First comes the spoken language, in which ideas are clothed in certain definitely regulated somuds. Then there is the written language, in which those somis are reduced to form, and are heard with the eye instead of the ear.

Then there is the linguage of gesture, which is little employed annong ourselves, but in some parts of the earth forms a necessary concomitant to the spoken language. or can be substituted for it. VThe Bosjesmans of Southern Africa, for example, are unalle to converse with freedom when in the dark, the visible gestures being needed to supplement the andible words. This necessity is so great that if they wish to talk in a dark night they are obliged to light a fire.

Among the Nortl American Indian tribes the language of gesture forms an important part of every man's education. 'I'here are very many of these tribes, and they all speak different dialects, which in many cases vary so much that they are practically different languages.

Were it not for some other means of communication besides spoken words, no one would be able to converse with another who did not happen to belong to his own tribe. Gestrres, however, take the place of words, and form a uni- versal language. This sign-language is very simple, is based upon definite principles, and is easy of attainment. Captain Burton has written an account of the sign-language, which ought to be carefully read by all travelers. The language as given by him is easily mastered, and by its nse, acquired in a few hours, an Englishman would be capable of conversing with any of the savage tribes of North $\Lambda$ merican Indians without understanding a single word of their spoken language.

'The English, in consequence of their physical constitution, which their Continental neighbors are pleased to call "phlegmatic," use gesture-language less than almost any nation upon earth, looking upon gesture in connection with language much as they do upon ornament in connection with oljects of utility. Yet even they use it, though sparingly, and almost unconsciously.

That its use is natural is slown by the untanght and graceful gesture-language of a child, which is able to express its thoughts by gesture long before it obtains the power of speech. I knew a child who managed to express himself so well by gesture that he did not trouble himself to speak a word until after lie had completed his third year. His mother was terribly distressed at his backwardness; but after he found the nse of his tongue he more than compensated for his previous silence, and I fancy that his mother would occasionally have preferred an interval of the gesture-language which liad been so distasteful to her.

In maturer years this silent language survires. 
To take a few fumiliar examples: The uplifted finger expresses the idea of warning als platiuly as if the word had been used. If one person tell another a tale, and his namative be received with an almost impereptible shrug of the shoulder, incredulity is expressed as clearly and as offensively as if the lie had been given in words. Similarly, the upraised evebrows express wonder, but at the same time imply belief.

'To shake the closed fist expresses menree, and indeed such a gesture is actionable at law. 'T'o present the palms of the hands toward an object expresses rejeetion, while the open arms equally express aceeptance. There are some ladies who are addicted to the feminine vice of tossing their heads when they meet with any thing which does not happen to suit them at the moment. It is really wonderful to see how much they enjoy it, and how they think themselves to have elevated their dignity together with their noses above the ordinary level of humanity. Their idea is a ludicrously false one, but they certainly express it by their gesture.

Again, words ean not express contempt more forcibly than the action of snapping the fingers or turning the back; nor ean words be more expressive of reneration than the act of bending the knee. Words are not needed to express derotion when the clasped hands and uplifted eye are seen; while remorse is shown by the cowering form crouching to the earth as if crushed by the weight of guilt, and conseious innocenee by the erect body and uplifted head.

Not to multiply further examples whieh will strike any one who takes the trouble to think on the subject, it is evident that ideas can be eonreyed by gestures without the use of words, and that any mode of transmitting ideas is a form of language.

The gesture-language is that which is ehiefly used by the lower animals when they wish to convey their ideas to man, and, in its way, it is as perfect a language as that which was employed by the ehild above mentioned, who did not choose to take the trouble of speaking when he could make himself understood by gresture; and, whether these gestnres be used by man, eliild, or beast, they are intended for the transmission of ideas, which are the result of reason, and not of instinct.

Painters would be in a very bad way if they were not aided by the natural language of gesture. They ean not paint ideas, but they can paint the gestnres which are expressive of ideas, and so can make themselves as well understood as if they had made use of the written language. Indeed, the same model does duty for all kinds of personages and all kinds of emotions, as long as the gestures can be represented. An old, gray-headled, long-bearded man, with his hail tussing in the wind and his hands wildly clinched, represents grief and madness, als personated in Lear. 'The same indivilual, with face upraised and a harp on his knee, will be adoration, personified by Javid. Let him shut his eves and hold ont his hands, and he represents dignified peinry in the person of Belisarius. The sinne rule holds grood with sculptors. Man really eould not go thiongh existence without a gesture-language, and that language, as we shall presently see, is the common property of himself and the lower animals.

Even among ourselves there is a recognized langunge of signs, namely, that by which we can exehange ideas with the deaf and dumb. It has been reduced to a form almost as definite as the written or spoken language; and it is worthy of notiee that very many of the signs are identical with those in use among the Indian tribes. Thus a deaf-and-dumb man who liad learned the signlanguage would be able to converse with the Indian tribes; while a man who was in possession of his powers of speech and hearing could neither understand them nor make himself intelligible to them if he were ignorant of this simple code of signs. I have seen evidence taken in a eourt of law by means of the sign-language, and sneh evidenee was accepted as if it had been spoken or written.

Lastly, there is the language of the oye, by whieh ideas are interchanged without the necessity of words or gestures. It is essentially the language of idea, and by it spirit speaks directly to spirit, conveying by a single glance of the eye thoughts whieh whole volumes would fail to express.

There is none so obtuse that he can not understand the fiery glare of anger, the soft, beaming glance of love, or the dull, purposeless stare of hopeless sorrow. When the mother contemplates her infant, her entire soul is poured through her eyes, and no language is adequate to express the boundless love whieh is manifested by the eye alone.

The look of appeal is sufficiently recognizable to be expressed by the painter's art, an admirable and familiar example of whieh is seen in the two faces in Millais's "Hugnenots." Solemu question and equally solemn response can be given in a moment, and without the use of word or sign; and there are those who have known a single glance giren and returned change the whole course of two lives. 
If animals possess reason in common with n1an, it is evident that they must be able to interchange thoughts with each other and with nran, when brought in contact with him. They inust possess a language of some sort, by means of which they can understand each other, can comprehend human language, and render thcmselves intelligible to man. All these conditions are fulfilled in the lower animals, and the inference to be drawn from them is self-erident.

'There is one distinction between the capability of understanding their own language and that of man, mamely, that they are born with the one and liave to learn the other. Newly hatched chickens, for example, understand their mother perfectly well, though they lave only entered the world an hour or so ago; they know what she means when she calls them to find what she has scratched up for them, and they know what to do when she gives them warning of danger. 'T'hey, again, are able to talk to their mother', and even the most incurious must have noticed how ditierent are their tones under various circunstances-say, for example, the little piping notes of content when all is going on well, and the cry of alarm when they have lost their way or are otherwise frightened.

Looking at the nerrous system of insects, in whom there is no definite brain, but merely a succession of ganglia united by a double nervous cord; many physiologists have thought that reason could not be one of the attributes of the insect race. Yet nothing is more certain than that they are able to converse with each other and communicate ideas, this fact showing that they must possess reason. As far as we know, the liymenopterous insects - namely, the bees, wasps, and ants-are the best linguists of the insect race, their language being chiefly conducted by means of their antenna. A good example of this was witnessed by me in the summer of $187 \%$.

At breakfist-time some pieces of the white of an egg were left on a plate. A wasp came in at the window, and, after fling about for a while, alighted on the plate, went to the piece of egg, and tricd to carry it off. Wrishing to see what the insect would do, I would not allow it to be disturbed. After several unarailing attempts to lift the piece of egg, the wasp left it and flew out of the window. Presently two wasps came in, flew direct to the plate, picked up the piece of egg, and in some way or other contrived to get it ont of the window. 'These were evidently the first wasp and a companion whom it had hought to help it.

I had a kind of suspicion that when the wasps reached their home they would tell their companions of their good fortune, and so I put some more egrg on the plate and waited. In a rery short tine wasp after wasp came in, went to the plate withont hesitation, and carried off a piece of egr. 'The stream of wasps was so regular that I was able to trace them to their nest, which was in a lane about half a mile from my house.

'The insect had eridently reasoned with itself that, although the piece of egg was too heavy for one wasp, it might be carried by two; so it went off to find a companion, told it the state of things, and induced it to help it in carrying oft the coreted morsel. Then the two had evidently told the other inluabitants of the nest that there was a supply of new and dainty food within reach, and had acted as guides to the locality. Here is positive proof that these insects possess a very definite language of their own, for it is impossible that human beings could hare acted in a more rational manner.

Every one knows that wasps carly out one of the first principles of the military art by always having the gate of their fortress guarded by a sentinel. Should there be danger, the scntinel gives the alarm, and out dash all the inhabitants at the offender indicated by the sentinel.

It is clear that, out of the many hundred wasps which form a full-sized nest, the individual who is to act as sentinel must be selected, and its task appointed. We do not know how the selection is made, but that such is the case is evident; for the rest of the wasps acknowledge their sentinel, trust to it for guarding the approaches of the nest, while they go about their usual task of collecting food for the young and new material for the nest.

As for the ants, some of their performances are absolutcly startling, so closely do they resemble the customs of human civilization.

'They have armies commanded by officers, who issue their orders, insist upon obedience, and on the march will not permit any of the privates to stray from the ranks. There are some ants which till the ground, weed it, plant the particular grain on which they feed, cut it when ripe, and store it away in their subterranean granaries. There are ants which are as arrant slaveholders as any people on earth ever were. They make systematic raids on the nests of other ants, carry off the yet unhatched cocoons, and real them in their own nests to be their servants.

'I'here are ants which bury their dead-a fact which was discovered by accident.

A lady had been obliged to kill some ants, the bodies of which lay about on the ground. Pres- 
ently a single ant found its dead companions, and examined them and went off. Presently it returned with a number of others, and proeeeded to the dead bodies. Four ants went to eneh corpse, two lifting it and the other two following -the main body, some two hundred in number, following behind. 'The four bearers took their office in turns, one pair relieving the other when they were tired. They went straight to a sandy hillock, and there the bearers put down their burdens, and the others immediately began to dig holes. A dead ant was then placed in each grave and the soil filled in. 'The most curious part of the proceedings was that some six or seven ants refiused to assist in grave-digging. Upon which the rest set on them, killed them, dug one large hole, and tumbled them unceremoniously into it.

In Froebel's work on South America there is a good account of the proceedings of some ants :

"I had several opportunities of observing the manners of sereral kinds of ants living in the houses. All of them are very inoffensive and eren useful creatmres. On one oecasion I mitnessed a remarkable instance of the concerted and organized action of a crowd of them. They were of a minute species, but, by the wonderful order and speediness with which they worked together, and which it would have been difficult to realize with men, they succeeded in performing a task apparently quite beyond their capability.

"They carried a dead scorpion, of full-grown size, up the wall of our room, from the floor to the ceiling, and thence along the under surface of a beam to a considerable distance, when at last they brought it safely into their nest in the interior of the wood. During the latter part of this achieveinent they had to bear the whole weight of the scorpion, together with their own, in their inverted position, and in this way to move along the beam.

"The order was so perfect that not the slightest deviation from an absolute symmetry and equality of distances and arrangement was observable in the manner of taking hold of the body of the scorpion, and in the movement of the little army of workmen. No corps of engineers could be drilled to a more absolute perfection in the performance of a mechanical task. According to a rough calculation, there must have been from five to six hundred of these intelligent little creatures at work. Besides those engaged in the transport, none were seen. A single one was sitting on the sting at the end of the scorpion's tail, as if placed there to overlook and direct the whole movements: all the rest were, withont exception, at work. The operation may have lasted about an hour."
This scene is an exaet reproduction, in the insect world, of the mamner in which the ancient Egyptians and Assyrians convered their colossal statues to their places. 'There we see hundreds of men all dragging at the multitudinous ropes attached to the car on which the statue lav, and all pulling in time to the gestures of a single man placed on the top of the statue. The ants, however, had a still more difficult task than the men; for they possessed no carriage on which to lay the scorpion, and were obliged to sustain the whole of its weight as they passed over the eeiling.

In the same work, Froebel has narrated another example of the manner in which ants ean combine, and make themselves intelligible to their fellow-insects :

"Anotler time I witnessed the transmigration of a whole state or commonwealth of ants, from a hole in the wall, aeross our veranda, into another hole in the opposite wall.

"Two facts struck my attention in this case. The first was, that the marching army of these insects, all moving in one direction, consisted of individuals of such a difference in size and sliape, that to consider them as belonging to one species seemed very difficult, and the idea of a commonwealth of different insect nationalities was strongly suggested.

"'The second was, that some little beetles, of the fumily of Coccincllide, marched along with the ants from one hole into the other; not quite of their own will, for I observed that several times one of them tried to deriate from the line, but was quickly brought back to the ranks by some of the ants placing themselves at its side. The fact of little beetles, of the very fiumily just mentioned, existing in the nests of ants is well known; but it is of considerable interest to see the fact repeated in distinct climates, with different species of insects of both tribes, and under opposite circumstances."

As to the different sizes of the ants, all entomologists know that, in the hotter parts of the world, the males, females, soldiers, and workers of the same species will vary in size from that of a wasp to that of a common garden ant, and that the shape and aspect are as different as their size. The second point is a very curious one. It has long been known that many beetles live in ants' nests, but I believe that this is the only record of the beetles accompanying the ants in their migrations.

We will now proceed to some of the higher animals.

The Scotcls shepherds, who are brought into constant companionship with their dogs, fully be- 
lieve that the animals not only understand the words of their masters, but have a langunge of their own in which they can communicate idleas to each other. So certain are they of this that a shepherd is quite as fastidions about his dog's companions as he would be about those of his own children.

It will be readily understood that in the great sheep-feeding districts of Scotland there is no doggish crime so mupardonable as sheep-killing. As long as a dog can be kept from strange companions there is no great danger, as a collie is scarcely able to master the active and powerful sheep of those parts-sheep which, by reason of their semi-wild life, are able to defend themselves against foes to which a southeru fuld-bred sheep would at once snccumb. But evil communications corrupt the nammers of dogs as well as of men, and there is the greatest danger of sereral collies uniting in their attacks upon the sheep.

Some time ago a couple of shepherds met in a market place, each, as a matter of course, accompanied by his dog, one of which had been suspected of sheep-worrying. After the mamer of dogs, the animals accosted each other, and soon assumed so remarkable a demeanor in their conrersation that their owners consulted together on their own account, and agreed to set a watch upon their dogs. On that very evening both dogs started from their homes at the same hour, joined each other, and set off after the sheep.

Here we have a direct example that dogs have a sufficiency of language to conrey ideas. 'The old offender had invited the young and innocent dog to go with him sheep-worrying, and had even managed to tell him the time when he was to start on his expedition. I have not been able to ascertain whether andible sounds wcre employed by the dogs, but I believe that the language, although perfectly understood by themselves and partly so by their masters, was entirely one of look and gesture.

An erent occurred near Leslie which corroborates the story just told respecting dogs and their power of understanding their own language.

A farmer had lost a considerable number of sheep, and so he and his shepherd watched carefully throughout the night for the purpose of detecting the dog which had worricd the animals. About the middle of the night they saw a troop of seren dogs making at full speed for the field where the sheep were kept. One dog was evidently the leater, and there could be no doubt that the aninals, which belonged to different owners, had pre-arranged their meeting, and eren settled the time at which they were to leare their respective homes. 'This could only have been done by means of some kind of language, which, though it did not consist of words, was as intelligible to them as human language is to mankind.

Two very remarkable instances of langnage and combination are given by Colonel W. Camploll in his "Indian Jomrnal." The writer is perhaps better known by his nom de plume, "The Old Forest Ranger." He was at Ranee Bennore on a hunting expedition:

"I witnessed this morning a curious instance of wolfish generalship that interested me inuch, and which, in iny limmble opinion, goes fill to prove that animals are endowed to a certain extent with reasoning faculties, and have ineans of communicating their ideas to each other.

"I was as usual scamning the horizon with my telescope at daybreak to see if any game was in sight. I had discovered a small herd of antelopes feeding in a field from which the crop liad lately been removed, and was about to take the glass from my eye for the purpose of recomoitring the ground, when, in a remote quarter of the field, concealed from the antelopes by a few intervening bushes, I faintly discerned in the gray twilight a pack of six wolves, seated on their hind quarters like dogs, and apparently in deep consultation.

"It appeared evident that, like myself, they wanted renison, and had some design upon the antelopes; and, being anxions to witness the mode of proceeding adopted by these fonr-legged poachers, I deternined to watch their motions. I accordingly dismounted, learing my horse in charge of the sowar, and, creeping as near the scene of action as I could, without being discorered, concealed myself behind a bush.

"Having apparently decided on their plan of attack, the wolves separated, one remaining stationary, and the other fire creeping cantionsly around the edge of the field, like setters drawing in a shy corey of hirds. In this mannel they surrounded the minsuspecting herd, one wolf lying down at each corner of the field, and the fiftl creeping silently toward the centre of it, where he concealed himsclf in a deep furrow.

"The sixth wolf, which had not yet moved, now started from his hiding-place and made a dash at the antelopes. The gracefnl creatures, confident in their matchless speed, tossed their heads as if in disdain, and started off' in a series of flying loomds that soon left their pursuer far behind. But no sooner did they approach the edge of the field than one of the crouching wolves started up, turned them, and chased them in a contrary direction, while his panting accomplice lay down in his place to secure wind for a fresh 
burst. Again the bounding herd dashed across the plain, hoping to escape on the opposite side; but here they were once more headed off by one of the crafty savages, who took up the chase in his tmm, and coursed them till relieved by a fresh hand from an opposite quarter. In this manner the persecuted animals were driven from side to side and from corner to corner, a fresh assailant lieading them at every turn, till they appeared perfectly stupefied with fear, and, crowdiug together like frightened sheep, began to wheel around in diminishing circles.

"All this time the wolf which lay concealed in the furrow near the centre of the field had never moved; and although the antelopes had passed and repassed within a few feet of him, and had, perhaps, even jumped over him, his time for action had not yet arrived. It now became evident that the unfortunate antelopes must soon be tired out; when it appenred probable that the surrounding wolves would have made a combined attack, and driven the terrified lierd toward the centre of the field, where the wolf which had hitherto been lying in reserve would lave sprung up in the midst of them, and secured at least one victim."

At this period of the proceeding the spectator shot the nearest wolf, whereupon the other fire decamped and allowed the antelopes to escape.

Here we have reason and a powel of combination for mutual action that would have clone credit to human beings.

The aneclote shows also that there is much more detail in the language of animals than is generally supposed. Each had its different post assigned, so that the wolves must have possessed some means of indicating that locality ; and each lundertook to play its own part in a scheme of no small intricacy, so that their language inust have been capable of expressing abstract ideas.

$\mathrm{Mr}$. Walter Elliot, also a mighty Indian hunter, mentions in a foot-note to Colonel Campell's account that he has witnessed similar instances of combination on the part of the same animal. Once he saw three gazelles chased by a single wolf. 'They made for a " "nullah," or ravine, and plunged into it. Presently two of the gazelles bounded up the opposite bank of the nullah, but the third gizelle and the wolf were missing. Going to the nullah in order to discorer what had become of the animals, Mr. Elliot found the missing gazelle in the jaws of three wolves. It was evident that it liad been decoyed into an ambush, two wolves having hidden themselves in the nullali, and the third driven the gazelles to the spot where his accomplices were concealed, thus making an by cmming for lack of speed.
I rather think that each species las its own dislect, and that there is another language which is common to all-al sort of animal lingua france, or "pigeon-English." For example, a cry of warning, no matter from what bird or animal it comes, is understood by them all, as is well known to miny a sportsman who has lost his only chance of a sllot by reason of an impertinent jay, crow, or magpie which has spied him, and has given its cry of alarm.

In Mansfield Parkyn's work on Abyssinia is a remarkable account of language and the consequent power of combination among the monkey tribe :

"You may see them qual'reling, making love, mothers taking care of their children, combing their hair, minsing and suckling them; and the passions-jealonsy, anger, love-as fully and distinctly marlied as in men. 'They lave a language as distinct to them as ours is ; and their women are as noisy and fond of disputation as any fishfag in Billingsgate.

"The monkeys, especially the Cynocephali, who are astonishingly clever fellows, have their chiefs, whom they obey implicitly, and a regular system of tactics in war, pillaging expeditions, robbing corn-fields, etc.

"These monkey forays are managed with the utmost regularity and precaution. A tribe, coming down to feed from their village on the mountain (usually a cleft in the face of some cliff), brings with it all its members, male and female, old and young. Some, the elders of the tribe, distinguishable by the quantity of mane which cover's their shoulder's like a lion's, take the lead, passing cautiously over each precipice before they descend, and climbing to the top of every rock or stone which maly afford them a better view of the road before them.

"Other's have their posts as scouts on the flanks or rear; and all fulfill their duties with the utmost vigilance, calling ont at times, apparently to keep order among the motley pack which fornis the main body, or to give notice of the approach of any real or imagined danger. 'Their tones of voice on those occasions are so distinctly raried that a person inuch accustomed to watch theii movements will at length fancy-and, perhaps, witl some truth-that lie can understand their signals.

"The main body is composed of females, inexperienced males, and young people of the tribe. 'Those of the females who have small children carry them on their back. Unlike the dignified march of the leaders, the rabble go along in a most disorderly manner, trotting on and chatter- 
ing, without taking the least heed of any thing, apparently confiding in the vigilance of their scouts.

"Here a fer of the youths linger behind to pick the berries off some tree, but not long, for the rear guard coming up forces them to regain their places. There a matron pauses for a moment to suckle hel oftspring, and, not to lose time, dresses its hair while it is taking its meal. Another younger lady, probably excited by jealousy or by some sneering look or word, pulls an ngly mouth at her neighbor, and then, uttering a -hrill squeal highly expressive of rage, vindictively snatches at her rival's leg or tail with her hand, and gives her, perhaps, a bite in the hind quariers. 'This provokes a retort, and a most unladylike quarrel ensues, till a loud bark of command from one of the chiefs calls them to order. A single cry of alarm makes them all halt and remain on the qui vive, till another bark in a different tone reassures them, and they then proceed un their march.

"Arrived at the coln-fields, the scouts take their positions on the eminences all around, while the remainder of the tribe collect provisions with the utmost expedition, filling their cheek-pouches as full as they can hold, and then tucking the heads of corn under their armpits. Now, unless there be a partition of the collected spoil, how do the scouts feed? I have watched them serelil times, and never observed them to quit for a moment their post of duty, mntil it was time for the tribe to return, or till some indication of danger induced them to take to flight."

Here we have clear proof of the existence of a definite language among beasts - a langmage so expressive that it conld be understood by a human listener. There are many birds which act in almost exactly the same mamner, a few being posted as sentinels, while the rest derour the crops in peace, knowing that warning will be given if danger should threaten them.

The animal above mentioned is the Dogfaced Baboon. Colonel Drayson, R. A., has given a similar acconnt of another species, the Chacma, of Southern Africa.

A ludicrous example of the possession of language of the monkey tribe is giren by Sir J. Bowring in his admirable work on Siam. During a jommey one of his snite fired at a monkey, wishing to secure the young one which she held in lier arms. Ile did not kill her, and the wounded mother retreated into the jungle, carrying her (hild with her. The rest must be told in sir John's own words :

"Five men immediately followed her ; but ere they had been ont of sight fire minntes, we saw them hurying toward us, shouting 'Ling, ling, ling,ling!' (i.e., monkey). As I conld see nothing, I asked Mr. Hunter if they were after the monkeys.

"'Oh, no,' he replied; 'the monkers are aftel' them.'

"And so they were, thousands mpon thonsands of them coming down in the most unpleasant manner. As the tide was out, there was a great quantity of soft mud to cross hefore they conkl gain the boat. Here the monkeys gained very rapidly upon the men; and when at length the boat was reached, their sarage pursuers were not twenty yards behind them.

"The whole scene was lndicrous in the extreme, and I really think that, if my life had depended upon it, I conld not have fired a shot. To see the men making the most stremnons exertions to get through the deep mud, breathless with their run and fright combined, and the army of little wetches drawn up in line within twenty yards of us, screaming and making nse of the most disbolical language, if we conld only have understood them. Besides, there was the feeling that they had the right side of the question.

"One of the refugees, however, did not appear to take my riew of the case. Smarting under the disgrace and the bamboos against which he ran in his retreat, he scized my grun and fired both barrels on the exulting foe, who immediately retired in great disorder, leaving four dead mpon the field. Many were the quarrels that arose from this affair among the men."

This incident shows clearly the existence of language among the monkers. Otherwise they could not have understood that one of their mumber had been injured by the hands of eertain men, and so quickly have organized a combined attack upon their foes.

The following anecdotes have been sent to me by a London physician, and forcibly illustrate the ficulty possessed by animals of communicating ideas to each other. The first is an example of dog lauguage.

"While I was living in the country with a friend, a most interesting incident was observed in the history of the dog.

"My friend had sereral dogs, two of which had a special attachment to, and an understanding with, each other. 'The one was a Scotch terrier, gentle and ready to fraternize with all honest comers. 'The other was as large as a mastiff, and looked like a compound between the mastiff and the large rongh stag-hound. Ile was fierce, and required some acquaintaluce before you knew 
what faithfulness and kindness lay beneath his rough and savage-looking exterior. The one was gay and lively, the other stern and thoughtful.

"These two dogs were often observed to go to a certain point together, when the small one remained behind at a corner of a large field, while the mastiff took a round by the side of the field, which ran up hill for nearly a mile, and led to a wood on the left. Game abounded in those districts, and the object of the dogs' arrangement was soon seen. 'The terrier would start a hare, and chase it up the hill toward the large wood at the summit, where they arrived somewhat tired. At this point the large dog, which was fresh and had rested after his walk, darted after the animal, which he usually captured. They then ate the hare between them, and returned lome. This eourse had been systematically carricd on for some time before it was fully understood."

The next anecdote shows that animals belonging to different species, such as the dog and cat, can communicate ideas to each other, and act in concert.

"A relation of mine in Dumfriesshire had a dog and a cat which were attached to each other in an extraordinary manner, and both were great favorites in the household. 'The dog, however, was not intended to sleep in the honse, and was earefully put out every night; but, strange to say, he was always fuund in the morning lying before the fire, wiih the cat by his side.

"One evening the master of the dog heard a sort of rap at a back-door leading to the kitchen, and saw the sagacious cat spring up and strike the latch, while the dog pushed open the door and entered in trimmph. This system must have long been carried on, and when it was discovered, I need not say how interested were the members of the houschold in these intelligent and really wonderful ereatures."

Most persons have heard of the celebrated rook parliaments, thongh rery few have seen then. I have an accomt written by a lady, who was at the time in bad health, and was reclining among some shawls behind a window-curtain, where even the sharp-eyed rooks did not detect her.

The account much resembles those that have already been given by other writers, but introduces one additional circumstance. The rooks (called crows by the spectator) assembled in a circle, and in the middle was one bird looking very downcast and wretched. Two more rooks took their places at its side, and then a rast amount of chattering went on. At last the two birds, which seemed to act as aceusers, pecked the centrial bird and flew off. All the others then set on the condemned bird, pecked it nearly to pieces, and went away, leaving the mangled body on the ground.

The lady who witnessed this remarkable seene was much struck by the variety of tones $\mathrm{cm}$ ployed by the birds, and their great expressiveness.

This aceount is eorroborated by Major Norgate in his "Notes on the Indian Crow," published in the Zoologist, p. 9650 :

"The crow has mectings for some reason or other; these the natives eall Punehayeti-al sort of court.

"I have several times seen these assemblies. Four or five crows will alight upon an open space, generally on green grass. Two or three will begin cawing, and in a minute or two sume forty or fifty of them will come flying toward the place by twos and threes from every quarter. They then form a kind of ring around one crow, which appears to have been an offender against some of the rules of their society, and they remain still for some mimites, the culprit never appearing to attempt to escape. Then, all of a sudden, five or six of them will attack the prisoner, pecking him, and striking him with their wings.

"On one occasion I saw the erow left dead on the spot, and on another the prisoner's wing was broken; but these courts, or whatever they are, suddenly come to a termination by the too near approach of a man or a dog. I saw one meeting which lasted twenty minutes; but no pumishment was inflicted on any of them, and no noise was made. The whole assembly flew off together: they were not disturbed at all, and they were eating nothing, for it took place on a bare plain. Of course, it must only be surmised as to why these crows are punished by the others; perhaps some close observer may discover the reason."

Here is casually noticed a rather important fact, namcly, that these crow parliaments are sufficiently common in India to have received a nume in the language of that country, and that one individual saw sereral of them. I mention this, because several accounts of crow parliaments seen in this country have beon received with considerable incredulity. The reader will observe that in all essential points the two narratives agree. My own correspondent is of opinion that the two birds which guarded the culprit were the accusers, and that it was their duty to inflict the 
first blow. There is a curions parallel here with that portion of the Mosaic law which ordained that in cases of capital punishment there must be at least two witnesses, and that they must cast the first stone at the eonvicted criminal.

An accomnt of a similar act of justice is related by Mr. J. Drew, in Harrdwicke's Science Gossip for October, 18i1. 'The erent occurred at Nansladron, in Cornwall.

"One summer afternoon my attention was drawn to a vast assemblage of rooks on our lawn. By the terrible vociferations they were making, it was evident that something very 1 musuil was being enacted; for, clamorous as these birds are by nature, the noise and excitement of this meeting it would be almost impossible to describe.

"After watching them for some time, it became clear that they were in the act of carying out some preconcerted punishment upon a luckless offender of their own flock; for on the ground was a black object in the form of a rook, which was eridently being pecked at, rolled over and over, and so passed on from rank to rank of the assembled multitude. That it was not a mere pastime was evident from the ruthless way in which feathers were pulled out and continuous blows given.

"Having waited about ten minutes, we felt a curiosity to know the effect of such ehattering ferocity upon the poor black object, and drew near to pick it up. Of course the rooks flew away with lond cawings as soon as we approached; but, to our great astonishment, the prostrate bird opened its eyes, spread its ragged wings, and made, as it best conld, for the nearest tree. Whether, if we had not interfered, the punishment would have been carried out usque ad mortem I know not. But clearly it was a good case to prove that the lower animals are gorerned by the same principles of thonght and action as we are, each grade varying only in its mental and moral qualities in proportion to the derelopment of the nervous system."

Here, as it will be noticed, the observer saw the infliction of the punishment, but not the trial which had eridently preceded it. Still he saw enough to show that the birds must have possessed the power of reasoning, and a language sufficiently definite to enable them to unite in a eommon olject.

Other birds besides erows and rooks can assemble, hold comncil, and agree to act on the result of their deliberations.

One of my friends, then living near Manches- ter, in the garden had a very fine mountain-ash tree, which always produced a plentiful crop of berries. Shortly before the fruit ripened a great number of thrushes got together at the end of the garden, and were very noisy, chattering, and eridently discussing some subject on which they were not agreed. 'This went on for' some time, the assemblage and chattering eontinuing daily. All this time the berries were ripening; and one morning an order appeared to be issued; the birds flew to the tree, and in a couple of hours there was not a berry left upon it. This occurred regularly during the three years in which my friend occupied the house.

Last year a somewhat similar erent took place in the garden of one of my neighbors, who is a great horticulturist, and rery successful with fruit as well as with flowers. There was a cherry-tree bearing in that year a remarkably heavy crop of fruit, which was carefully watched until it ripened. One erening the owner of the garden, seeing that the cherries had just reached the proper stage for picking, ordered the gardener to gather them on the following morning. But the birds seemed to know as much about fruit as he did, for when the gardener came with lis basket the crop of cherries had ranished, and nothing was left except the stalks, each with the stone still attached to it.

It was evident that in this ease the birds must have entered into some agreement on the subject, and must have arranged among themselves not to meddle with the tree until the fruit was quite ripe. The disappointed owner of the cherry-tree stontly avers that the birds overheard him give the order to the gardener, and so anticipated lim; but the former aneclote, showing the power of mutual arrangernent among birds, explains the latter.

An example of a somewhat similar mode of action was related by Mr. G. B. Clarke, of Woburn, to the Rev. F. O. Morris, and by him published in the Naturalist:

"In the summer of $18 \pm 9$ a pair of martins built their nest in an archway at the stables of Woburn Abbey, Bedfordshire; and as soon as they had completed building it, and had lined it, a sparrow took possession of it, and although the martins tried several times to eject him, they were unsuccessful. But they, nothing daunted, flew off" to scour the neighborhood for help, and returned in a slort space of time with thirty or forty martins, who dragged the unfortunate culprit out, took him to the grass-plot opposite, called 'The Circle,' and there fell on him and killed lim." 
This story was told br Mr. Clarke to Mr. Morris a few days after its occurrence. It is useful in this place as showing that birds are able to communicate their thonghts to each other by means of a limguage. Snpposing that we had heard the aggriered martins taliking to their friends, we should have distingnished nothing but a meaningless twitter. But, even with human beings, especially those who are meducated, the sound of a strange language is scircely more intelligible than the twittering of birds or the bleating of sheep; and, indeed, the well-known term of Barbarian-i.e., those whose language is nothing but "bar-bar"-shows how the somnd of an uuknown language affected even the well-educated and cultivated Athenians.

It is not likely that in the language of animals there are any principles of construction snch as are possessed by all human languages. But the same effect may be produced by different means, and the reader will see that in this instance no hmman language, howerer perfect its construction, could have served its purpose better than did the inarticulate langmage of the birds. They told their friends that their dwelling was nsmred by an intruder too strong to be ejected by them; they asked for united assistance, and arranged the comrse to be pursned. Hald not this been done, it is erident that the birds conld not have acted so perfectly in concert.

In fact, wherever animals of any kind form alliances and act simnltaneonsly for one common object, it is evident that langunge of some sort must be employed.

Here is a case where one dog saw another in difficnlty, and went to give it advice. Finding that its advice was not taken, it went again, and forced the relnctant animal into action.

'The dog, a little black-and-tan terrier named "Beau," and his owner were at Penmaenmawr, on the coast of North Wales. They were one day on the sands, and were overtaken by the tide, which cut them off from the shore by a belt of water. A bathing-machine came up and took off' the dog's owner, Bean refusing to enter the machine, of which he seemed to be snspicions. The rest must be told in the writer's own words, taken from the accomnt in Old and New, for December, 1873 :

"When I found myself on the beach, I looked for my dog, thinking that he would probably come swimming after the machine. But no: the little idiot was still on the island, yelping and barking in great distress. I called to him for at long time, bidding him swim across, as I knew that he conld use his limbs almost as well in wa- ter as on land. Put the nanglity animal would not come, and meanwhile the sea wis gaining on the sand, and Bean had scarcely space to stand and whine.

"Playing near me on the beach was a large, rough-haired, brave dog-a sort of half-bred retriever, I shonld suppose. Ile perceired the fix we were in, and snddenly dashed through the walter and went up to Benu, and said something to him. I'don't know what he said; but I have no doubt that he conuseled Beau to swim across to his mistress. Alas! the kind, brave dog retnrued to dry land, but no Bean. By this time the sea had risen round my little terrier, and he was himself like a tiny black-and-tan island.

"Now what did the brave dog do? For the second time he dashed through the water and stood beside the shivering, yelping creature; then he went behind Bean, and very gently but firmly pushed, pushed, pushed lim througl the water toward the place where I was standing. As soon as they were both fairly in the deep sea, and it seemerl to be a case of sink or swim with Master Beau, the wise, brave dog let him go, and with a few rigorous strokes bronglit himself to shore. Bean, having received such an impetus, rery soon presented himself dripping and breathless at my feet, amid the applanse of the assembled multitnde. 'Tlie brown dog, like a true hern, made no fuss about what he bad done, and I had notling to give him but a pat on the liead. His master was certainly not on the beach at the time, and I do not think I ever saw the dog again."

In the well-known Science Gossip there is a very interesting paper by Mr. E. F. Ehwin on the habits of an ant called Myrmica ruginodis. As is their manner, two of them had been fighting, and one had succeeded in catching his opponent by one of the antenne. Auts always try to do this, as, if they succeed, the adversary succumbs at once. In fact, with regard to ant combatants, the result of seizing the antenna is precisely that which is known anong pugilists as "getting the head into Chancery, "namely, rendering the opponent helpless.

Another ant, coming up, seized the victim by a leg, and tried to pull it away, but in vain, and though a crowd assembled round the combatants, they conld not put an end to the fight. At last a single ant ran up and stroked with his antenna the victor, who at once released the prisoner, and both the combatants and the spectators went qnietly away.

'This is another' example of an animal assisting its fellow-creature, and doing so by means of its 
own language, when force had proved unavailing.

The following remarkable instance of the communication of ideas among the lower animals is narrated by the Rev. C. Otway:

"At the flour-mills of Tubberakeena, near Clommel, while in the possession of the late $\mathrm{Mr}$. Newbold, there was a goose, which by some accident was left solitary, without mate or offspring, gander or goslings. Now it happened, as is common, that the miller's wife had set a number of duck eggrs under a hen, which in due time were incubated; and, of course, the ducklings, as soon as they came forth, ran with natural instinct to the water, and the hen was in a sad pucker-her maternity urging her to follow the brood, and her instinct disposing her to keep on dry land.

"In the mean while up sailed the goose, and with a noisy gabble, which certainly (being interpreted) meant, 'Leave them to my care,' she swam up and down with the ducklings, and when they were tired with their aquatic excursion she consigned them to the care of the hen.

"The next morning, down came again the ducklings to the pond, and there was the goose waiting for them, and there stood the hen in her great flusteration. On this occasion we are not at all sure that the goose invited the hen, observing her maternal tronble; but it is a fact that she being near the shore, the hen jumped on her back, and there sat, the ducklings swimming, and the goose and hen after them, up and down the pond.

:This was not a solitary event; day after day the hen was seen on board the goose, attending the ducklings up and down, in perfect contentedness and good-humor-numbers of people coming to witness the circumstance, which continued until the ducklings, coming to days of discretion, required no longer the joint guardianship of the goose and the hen."
On the evening of January 15,1874 , I received a remarkable corroboration of the truth of this story. I was narrating it to a lady, who I found was perfectly acquainted witl the facts. She had heard the story told by a friend of hers, who had witnessed the curious alliance between the hen and the goose, and had not the least idea that it had ever appeared in print.

There are one or two points abont this narrative which are deserving of notice. 'That language was employed by the goose, the hen, and the ducklings, is evident enough; but it is a curious question whether the ducklings understood the hen better than the goose, or vice versa. I am rather inclined to think that when a hen tries to call from the water the ducklings which she has hatched, she fails because she does not know how to express herself. Her own chickens would never venture into the water, and she has no words in her vocabulary to suit the occasion.

Ducklings understand a duck well enough; but when they are in the water they do not pay the least attention to the hen on the land, though she may flutter about in the greatest distress, and use every means in her power to call her fosterchildren to the shore. It seems, in this case, as if the aquatic goose could talk to the aquatic ducklings, both having the same expressions in their vocabularies. It could talie charge of them as long as it thought proper, and, when the time came, order them ashore, and deliver them over to the hen. They did not obey, or did not understand the hen, when she called them to come on shore; but they both understood and obeyed the goose.

That there was also a language common to both parties is evident from the action adopted by the hen. She conld not have sat on the back of the goose unless invited by the latter, which, as we shall see in the course of the work, is a bird possessed of great intellectual powers. 


\section{CHAPTER VI.}

\section{LANGUAGE- [HUMAN].}

Necessity for Communication of Ideas between Man and the Lower Animals.-The Latter able to Make Themselves Intelligible to Man.-The Gander and the Goslings.-The Skye Terrier and the Distressed Kitten.-Gesture-Language of Cats._Language of Intonation in Man and Aninals._Gesture-Language Employed by Animals as well as Man.-Gesture-Language of the Rat.-Capability of the Animals to Understand Human Langnage, even when not addressed to them.-The Dray-horse and their Drivers."Turk," the French Dog._A Parrot Speaking Two Languages._Various Parrut Stories.-The Mastiff Overhearing the Midnight Conspiracy.-The Retriever Understanding his Master and Anticipating Him. - "Rory" and "Banquo" Obeying various Orders.-How to Teach Animals.- "Ned" and the Rabbit. __ "Carina"s" Pitiful End.-A Canine Umpire between a Farmer and his Shepherd.-A Canine Connoisseur in Wools._-"Sweep" and the Cows._Baldie Tait's Collie Dog "Hastie" and his Dog "Susy."How the Collie Dog "Watch "Understood his Master and Helped Him ont of a Scr.lpe._. Ben" Evading an Overheard Order of his Master._- "Ilelp" Overhearing and Evading an Order for his Execution.Another Dog Acting in a precisely Similar Manner._Dodge and Connter-dodge._- Bijon," the Spitz Dog, Accepting a Reproof and Altering his Behavior.-The Hon. Grantley Berkeley's Dogs, aucl their Comprehension of Human Langunge.- "Missy" Understands the Doctor's Order, and Acts upon it.-The Cat "Rosy" Sent upon a Message to a Lady, and Delivering it Intelligibly.

Tur next branch of the subject extends to man as well as beast. We have seen that the beasts possess a language by which they can communicate ideas to each other, and that they can act upon the ideas so conveyed. Wc have now to see whether they can convey thcir ideas to man, and so bridge over the gulf between the higher and the lower bcings. Indecd, if there werc no means of communicating ideas between man and animals, domestication would be impossible.

Every one. who has possessed and cared for pet animals must have observed that they can do so. In many cases even their own language becomes intclligible to man. Just as a child that can not pronounce words expresses its meaning by intonation, so there is all the difference in the world between the different modes of barking of the same dog. There is the bark of joy or welcome, when the animal sees its master, or anticipates a walk with him. Then there is the furious bark of anger, if the dog thinks that any one is likely to injure himself or his master. And there is the bark of terror, when the dog is snddenly frightened at something which it can not understand. Supposing that its master could not see the dog, but only heard it bark, he would know perfectly well the ideas which were passing through the animal's mind.

Take the cat. Every one who has kept cats knows the difference bctween the mew of distress and that of ordinary conversation, the purr of pleasure-the little gratified chuckle of content when touched by friendly hands, and the low, loving tones in which a mother-cat talks to hel kittens. It is the same with birds. A pet canary, for example, always knows how to call its master, and when it sces him will give a glad chirrup of recognition quite distinct from its ordinary call.

The bees and wasps have quite a different sound in their wings when they are angry to that which they emit when only at their ordinary work. It is a distinct menace or challenge to a supposed enemy, and any one who is conversant with the ways of these insects understands it, and makes the best of his way off.

These are examples of sound-language, while the gesture-language is wonderfully extensive and expressive. If a cat were to say in so many words, "Pleasc open the door for me," it could not convey its ideas more intelligently than it does by going to the door, giving a plaintive mew to show that it wants help, and then patting the door. The dog, or, indeed, any animal accustomed to live in the house, will act after a similar fashion.

Here, then, we see that the lower animals can form connected ideas, and can convey them to man, so that the same ideas are passing at the same instant through the minds of man and beast, showing that they possess the sane faculties, though of different extent. 
The following anecdote of a lat shows low expressive and intelligible is the language of gesture: A gentleman living in Kent liad a faney for taming animals, and among others lad some rats, which were on the most friendly terms, and used to run about him as he sat in his room. One of lis rats had a litter of young, and, in order to insure their safety, they were placed in a bird-cage and lumg on a wall.

One night, after their master was asleep, he was awakened by something patting his cheek, and found it was one of his tane rats. He tried to sleep again, but the animal would not allow it, and was evidently disturbed about something. As soon as he obtained a light, the rat went to the door, and looked at him as if it expeeted him to follow. He did so, and it led him down the stairs into his room, and took him to the spot where one of the young was lying, having fallen from its eage.

Suppose that we substitute for the rat a deafand-dumb man or woman, the action would hare been alnost exactly the same, as would have been the ideas that were so lneidly conveyed by the language of gesture. The animal found that it was unable to put back its fallen young one, and must have caleulated that its master was taller and stronger than itself, and able to replace the young rat. So it went in search of its master, traced him to his bedroom, which it must have done by the sense of smell, awoke him from his sleep, and showed him where lis assistance was needed.

An anecdote of a somewhat similar character will be related under another heading, the actor being a dog instead of a rat. Indeed, most of these anecdotes illustrate several charaeteristics common to man and beast. I might hare placed this present anecdote under the heading of Parental Lore or Reasoning; but as it shows that, by means of their own language, beasts can convey their thoughts to man, I have placed it in its present position.

How completely animals can make themselves understood by man, especially when they wish to help each other by the aid of man, will be seen in many of the anecdotes narrated in this work. Here is a case where a gander managed to convey ideas to human beings:

"I was once sitting at my window reading, when a gander came up and stood at the window, nttering the most discordant sereams, and making the strangest gestures with his head. I was aware that he was a knowing bird, but was not prepared for the sequel.

" $\Lambda$ s soon as niy wife and I came out he waddled away round the stables and out-houses until he came to the mill-wheel. Then he stopped, went forward a few piees, and kept looking lound at us. We could see nothing wrong; but in a short time we heard the plaintive voice of some young goslings which liad fallen through the nill-lade, which had been left open.

"There was no possibility of rescue except by putting on sufficient water to wash them through the conduit. I did so, ran to the end, caught them as they were washed out, and restored them to their delighted parent. The gander seemed overjnyed, as could be seen by his aetion as lie strutted off to a place of safety, conscious that he had done great things. So he had."

As an example of gesture-language, nothing could be more clear and intelligible than the method employed by a Skye terrier belonging to one of my correspondents.

He had formed a friendship with a kitten, and the two were one day in the garden. Presently the kitten wished to gro into the house, and finding the door shut, tried to call the attention of the servants by mewing under the window. She could not suceed in making them hear, whereupon her friend, the Skye terrier, picked her up gently in his moutl, held her in front of the window and shook her baekward and forward so as to be seen by the servants. They understood what the animal meant, let the litten into the house, and ever afterward the dog employed the same expedient. It is exactly that which would have oceurred to a human being under similar circuinstances.

On account of the exigencies of space, I am olliged to omit many anecdotes which show the power of gesture-language in the lower animals. I must, however, mention one or two more. I have at the present time a cat which is not as companionable as I like to see a cat, being rather of a retiling and self-seeking disposition.

Nevertheless, she is quite aware of the fact that I can understand lier language, and always comes to me in any difficulty. She is rather giren to straying, I fear, in some poaehing raids upon a neighboring rabbit-warren, and consequently finds herself locked out of the house. When this is the ease, she jumps on the sill of the window, raises herself on her hind legs, so as to peer above the dead-glass blind, looks at me, and sets up a most piteous mew, or rather howl. No sooner do I rise than she jumps down, and before I can reateh the door she is already there. purring and rubbing herself against it in anxious expectation. 
She comes in very slowly, gives a passing greeting, and then goes off to the kitchen, where she has two children, who are quite as big as herself, and all three coil themselves up into an indefinite heap of black and white fur, in which a head, a tail, or a leg occasionally slows itself withont any particular reference to any individual animal.

A correspondent has furnished me with a very similar account of her own cat, "Daisy." In almost exactly the same manner the cat used to make herself very conspicuous at the window. Her mistress would then point toward the door. 'The cat, having made her own gesture-language intelligible, understood that of her mistress, and went to the door in certain expectation that it would be opened for her.

Examples of animals making their language intelligible to man conld be multiplied ad infinitum, and $\mathrm{I}$ therefore pass to the next division of the subject, namely, the capability possessed by the lower animals of understanding the language of man.

That many of the lower animals understand something of human language is a familiar fact. All the domesticated animals, especially the dog and the horse, can comprehend an order that is given to them, though, perhaps, they may not be able to understand the precise words which are used. Yet there are many occasions, it is evident, when the knowledge of human language does extend to the signification of particular words.

Some of my readers may remember the elephantine dray-horses which were engaged to draw the funeral car of the late Duke of Wellington. When the time for starting arrived there was a hitch in the proceedings, for the horses could not be induced to move. At last some one hit upon the reason, and brought a drayman, who said, "Gee, there!" or words to that effect, on which the animals started at once. These horses are never beaten, are always treated with kindness, and are directed entirely by voice, the long whip being only used for ormament, or for gently stroking the animals.

There is a French dog called "Turk" near my louse, who was in a very uneasy state of mind for some time after he came to England. He did not know English, and was as puzzled as if he had been a human being under similar circumstances. If addressed in French, he seened quite delighted and at his ease; but it was not for some time that he learned Einglish sufficiently to be comfortable.
There was a parrot, well known to our family, which was able to speak in two languages, and, when addressed, always replied in the language used by her interlocutor, speaking English or Portuguese, as the case might be.

I never yet met with any owners of pet talking parrots who had not come to the conclusion that the birds not only imitate human language, but that they understand the signification of the words which they utter, and use them accordingly. I personally knew two parrots who, if the servant neglected to feed them at the proper hour of the morning, would call her by name, and shout loudly for breakfast. There was another parrot -a green one-whom I did not know in life; having only seen her preserved skin in a glass case. She was a great favorite with the family, being allowed to go at large over the house, and in consequence was bronght into much closer relationship with lumman beings than is generally the case with birds.

None of the family had the slightest doubt that Polly was quite as well acquainted with the meaning of the words which she spoke as any of them could have been. Sometimes, before her feeding-time, she would call out, "Cook! cook! I want potato." She knew what potato was as well as the cook did, and if any thing else was put in the pan she would take the ressel in her beak, throw out all the contents, and then cry, "Won't have it! turn it out!"

Now she had never been taught either the deed or the words. When she arrived in the family she was new from her voyage, and could only speak a sort of jabber, called by the sailors "bush-talk," probably picked up from the natives, together with a very few expressions, most of which were of a nautical and decidedly objectionable character. In all probability she had noticed one of the servants use those words when throwing something away which she disliked, and had imitated her both in word and in gesture.

On another occasion one of the children, who was then about seven or eight years of age, had been reading abont a mode of secret writing by means of lemon-juice, and was fired with a desire to try the experiment for herself. There did not happen to be a lemon in the honse, and so she thought that she wonld try what vinegar would do. One of my children, by the way, took just the same idea a few months ago.

The only way to get at the rinegar was by intercepting the cruets as they were bronght out from her parents' dinner. So she placed herself in readiness in the kitchen, took the vinegar, and was pouring it into a spoon, when she was inter- 
rupted by the parrot, who called out, "I'll tell mother! 'Turn it out! turn it out! turn it out!" Whereupon the conscience-stricken child threw away the cruet and the spoon, and ran off to the nursery as fast as she could. She had the fullest belief that the parrot really would tell her mother.

The few scraps of language which she had learned on board ship were occasionally produced just where they ought to have been omitted. On one occasion the remarks were so singularly inopportume that one of the fumily offered a remonstrance, saying, "Oh, Polly! Polly! who could have taught you such language?" Whereupon the bird at once replied, "You did." It is impossible, or, at all events, in the highest degree improbable that the bird should not have understood the language of its interlocutor as well as herself.

Being in a family almost entirely composed of girls, Polly had an objection to the opposite sex, especially in the form of boys. On one memorable occasion some boys had come on a visit, and, after the manner of their kind, becane very uproarious. At last Polly could endure it no longer, but called to one of the daughters of the house, "Sarah! Sarah! here is a hullaballoo!" Parrots, by the way, have a curious predilection for the name of Sarah, which seems especially easy for them to pronounce.

The same parrot always looked out for the presence of the mistress of the house at the breakfast-table. If she did not come down before the meal was begun, Polly would begin to inquire after her in a plaintive tone, "Where's dear mother? is not dear mother well ?" and so on, evidently having heard and understood similar comments by members of the household.

A very similar circumstance is related of a parrot by one of niy correspondents.

It was an established custom in the household that at evening prayers the dog and the cat were to accompany the servants. One evening the dog made his appearance without his usual companion; whereupon the parrot called out, "Where's Cattie?" this being the familiar name by which the cat was called in the house.

Instinct is quite out of the question in any of these cases. The bird had first nsed its reasoning powers, and had then communicated the result to human beings in their own language.

The following anecdote, related by the late Rev. Cassar Otway, who produces vouchers for the exact truth of the story, affords a remarkable instance of the capability possessed by the lower animals of understanding the language of man :
"A gentleman of property had a mastiff of great size, very watchful, and altogether a fine, intelligent animal. 'Tliough often let out to range about, he was in general chained up during the day.

"On a certain day when he was let out he was observed to attach himself particularly to his master. When the serrant came, as usual, to fasten him up, he clung so determinedly to his master's feet, showed such anger when they attempted to force him away, and altogether was so peculiar in his manner, that the gentleman desired him to be left as he was.

"With him the dog continued the whole day; and when night came on, still he stayed; and on going toward his bedroom, the dog resolutely, and for the first time in his life, went up with him, and, rushing into the room, took refuge under the bed, whence neither blows nor caresses could draw him.

"In the midst of the night a man burst into the room, and, with dagger in hand, attempted to stab the sleeper. But the dog started at the robber's neck, fastened his fangs in him, and so kept him down that his master had time to call for assistance and secure the ruffian, who turned out to be the coachman. He afterward confessed that, seeing his master receive a large sum of money, he and the groom conspired together to rob and murder him, and that they plotted the whole scheme leaning over the roof of the dog's kennel."

The foregoing statement does not assert that the dog understood human language as completely as the men themselves did. But it is evident that the animal did gather from the conversation of the men that they intended to injure his master. 'The narrator does not state whether the conspirators mentioned any particular time for the murder, which was probably left to opportunity. The companionship of the dog during the day (which the intending murderers knew) might have prevented them from attacking their master by daylight, while his presenee at night (which they did not know) effectually counteracted their plot.

Here is another anecdote, which shows that an animal is capable of moderstanding human language even although it be not addressed to it personally. A gentleman who possessed a very intelligent retriever dog was going from home for some time, and arranged that the dog should be sent to the house of a friend during lis absence. On the day fixed for his departure the dog went on his own account to the house, and there remained until his master's return.

When his master did come back the dog was 
orerjoyed to see him, but became uneasy at the long call which was being made. He evidently took it into his head that his master was meditating another absence, and every time that he heard the hall door shut he rushed up-stairs to make sure that his master was in the house. At last, losing patience, he took his master's hat out of the hall, and carried it up-stairs to him, as a broad hint that he had better go home.

'The following quaint anecdote is told by the late Charles Dickens, and is given in Forster's "Biography." It is evident from internal evidence that the district was given to brick-making. The story illustrates the capacity of the dog for understanding human language, and conveying ideas to human beings :

"I must close (14th of May, 1867) with an odd story of a Newfoundland dog-an immense, black, good-humored Newfoundland dog.

"He came from Oxford, and had lived all lis life at a brewery. Instructions were given with him that, if he were let out every morning alone, he would immediately find out the river, regularly take a swim, and gravely come home again. This he did with the greatest punctuality, but after a little while was observed to smell of beer. She was so sure that he smelled of beer that she resolved to watch him.

"Accordingly lie was seen to come back from his swim round the usual corner, and to go up a flight of steps into a beer-shop. Being instantly followed, the beer-shop keeper is seen to take down a pot (pewter pot), and is heard to say,

"Well, old chap! Come for your beer, as usual, have youl?'

"Upon which he draws a pint and puts it down, and the dog drinks it.

"Being required to explain how this comes to pass, the man says:

"'Yes, ma'am; I know he's your dog, ma'am; but I didn't when he first come. He looked in, ma'am, as a brick-maker might-and then he come in, as a brick-maker might-and he wagged his tail at the pots, and he give a sniff round, and conveyed to me as he was used to beer. So I drawed him a drop, and he drank it up. Next mornin' he come agen by the clock, and I drawed him a pint, and ever since he has took his pint regular." "

My own dog "Rory" perfectly understood much of our conversation, and if told by any of us to fetch the slippers, to shut the door, to wipe his feet, or to put the cat down-stairs, he always performed the right act, showing that he knew the ideas represented by different words.

I know a dog, named "Banquo," who has learned to wipe his feet on the mat when he goes to a strange house; but on no consideration can he be induced to do so in his own house, where he considers himself privileged to do as he likes. Now my Rory acted in a very different manner, for he always wiped his feet whether they required it or not, and would never think of entering a room until he had rubbed all his feet for some little time.

In connection with this habit, I must mention the case of a gigantic Newfoundland dog belonging to a clergyman. He had not learned to wipe his feet, but he did know when they were dirty, and acted accordingly. When he cane in with dirty feet, he crept into the hall gently, and so up-stairs, taking care not to allow his footsteps to be heard. But when his feet were clean, he would clatter up and down stairs, making almost as much noise as a pony.

The dog "Banquo," who has already been mentioned, has a fine capacity for imitating a lady in hysterics. When told to go into hysteries, he sits in his mistress's lap, howls, yelps, flourishes his paws in a most fantastic manner, and ends by flinging himself backward. But he nerer performs this last feat without looking to see that a protecting arm is ready to catch him as he falls, thus adding to the truth of the representation. I have often seen him go through this performance, and a most ludicrous one it is.

The lady who possesses this animal, and who has taught it many comical tricks, sends the following remarks on the training of dogs:

"Any one wishing to educate dogs should commence by teaching them a few simple words (not blows), with occasional rewards for proficiency in any accomplishment. Twilight, and the dim but cheerful light of the winter fire, seems a fitting time for a pause in the day's work o1" the day's amusements, and then our little dog Banquo thinks himself entitled to share in the conversation. Last winter, having taught him that his two fore paws are his hands, I showed him how to warm them by sitting up and holding them outstretched to the fire. I remember at a friend's house seeing three cats on three footstools, in undisturbed possession of the dining-room fire. Our dogs are never allowed thus to monopolize either fire or hearth-rug, therefore the command 'Come and warm your hands' is generally most willingly obeyed."

The following anecdote is sent to me by a gentleman living at Bassendean :

"I had a Bedlington terrier, called 'Ned,' a very clever and intelligent dog. A few months ago I was in the Bassendean bog, when Ned 
started a rabbit among some whins. 'The rabbit lan toward the dike, and escaped its pursuer by getting into a hole in the dike. 'Two men happened to be passing at the time, and, though strangers to the dog, they helped him by pulling aray some stones at the place where the rabbit had concealed itself.

"Ned immediately sprang into the hole, canght the rabbit, and, after killing it, ran off with it to me, a distance of three or four hundred yards. I said to the dog, 'Ned, you scoundrel, how dare you take the rabbit fiom those men?' 'The words were scarcely out of my month when my dog started off as fast as he could run, with the rabbit in his mouth, and laid it at the strangers' feet.

"Any dog may be trained to carry things to his master, but this is the only instance I know of where the dog took the thing to a stranger. It certainly showed that he understood my words.

"When I am ont in the fields, Ned is always told to take care of my coat, in the pocket of which I often have large sums of money. He has sometimes been left in the field alone until eight o'clock at night, and, althongh the field has been full of laborers and Irish reapers, not one of them has dared to touch the coat. The dog is peculiarly mild and gentle in his temper, but he will not permit any cne to touch his master's property."

The following pathetic little story is from the same source :

"Mr. H L had a beantiful little Blenheim spaniel, called 'Crrina.' Abont the beginning of 1873, while the fanily were from home, the gardener slept in the house to take care of it.

"One night Carina, who had a family of healthy puppies about a fortnight old, came to the man's room, and scraped at the bedclothes until he awoke. Without striking a light or examining the dog in any way, the man said, 'Carina, go back to your puppies,' and the dog accordingly went away. In a short time she came again, and awoke the man in the same way. She again receired the same order, and obeyed it as before. In the morning, when the gardener went to look at the dogs, the puppies were quite well, and Carina was lying by their side quite dead. Her puppies survived, and were brought up on cow's milk."

It is evident that the poor little dog felt her end approaching, and tried to make her last farewell before she died. 'That she was not understood was not the fault of the dog, but of the man, who was too dull or too sleepy to comprehend her meaning, though she conld understand him.

Here is an account of a dog which shows that animals who live much with mankind manage to learn more of lnman language than is generally supposed. It was sent to me by a lady who knew the dog, the collie named "Moss," who has already been mentioned:

"His master and the shepherd were employed in moving sheep from one part of the farm to another. On reaching a certain point they fell into a dispute about the number of the sheep, the shepherd saying that they had the proper number, while the farmer thought that there ought to be one more. Not being able to decide, they jokingly appealed to Moss. The dog at once started off, and presently retnrned, driving before him the missing sheep, which he had brought from a spot quite out of sight, and a considerable distance on the opposite side of a hill."

Collie dogs are noted for the manner in which they can understand their masters' wishes; and the following anecdotes sent me by a Scotch gentleman show that they not only comprehend his general meaning, but the actual signification of his words :

"For several years within the last half century a deceased friend of mine was extensively engaged in the wool trade, and was a considerable buyer in Dumfriesshire. In one of these journeys, and after a forty-mile drive in his gig, he reached the house of a hill farmer in that country, arriving just at the close of the day. The farmer told him that his samples of wool were at some distance from the house, and that he wonld submit them for inspection on the following morning. My friend met with an hospitable reception, and as the hours of evening glided on the conversation turned on the management of sheep and cattle, and especially on a fine breed of shepherd dogs possessed by the farmer.

"Farly in the morning all were astir, and the farmer and his visitor left the house for the pnrpose of examining the different kinds of wool. But great was the astonishment of my friend when they reached a level patch of ground between high hills where there was nothing to be seen but a shepherd and two dogs, to he told that this was the place for inspecting the wool.

"He was asked which kind of wool he would look at first, and, having named the kind, the shepherd called one of the dogs, and directed him to turn the sheep upon one of the hilks, and bring them to him. The wise animal bounded off, and in a very short time the sheep were seen descending the hill by an easy pathway. 'The wool was examined, and the sheep driven back to the hill by another road. In the mean while the second $\log$ was sent to bring forward anothor breed of sheep from a different place, and so ons 
until all was finished, and without the least confusion. This plan was followed by the worthy farmer because he had not been able to find time to clip his sheep."

$J-\mathrm{P}-$, an elder in a Border congregation of the United Presbyterian Cliurch, and a very truthful and worthy man, lately informed me that when he was a young lad he was at service at $\mathrm{B}$ - farm, in Berwickshire, and had charge of the cattle. In the discharge of his duties he was accompanied by a very intelligent collie dog, called "Watch."

The farm is bounded on the west by the river Whiteadder. Its stream is comparatively trifling in dry weather; but, owing to the drainage of the high lands on its banks, whenever rain falls in any quantity hundreds of little rills pour into the channel of the river, so that in a very short time it overflows its banks. For the same reason it diminishes rapidly when the rain ceases.

On one occasion, the day being stormy and cold, he went into one of the cottages to warm himself, and on coming out he observed that one of the "kyloes" had strayed from the rest. On looking abont, he saw the missing animal grazing among some cattle belonging to another farm on the opposite side of the river. During his absence in the cottage a rain-storm had come on, and the river had risen to a flood, so that he found it impossible to cross it and bring back the strayed beast.

Not knowing what to do, and without any expectation that he would be understood, he said to the dog, "Watch, I canna gang through to fetch the kyloe; yell hae to gang." The intelligent animal inmediately plunged into the rapid rolling water, and reached the opposite bank. He went straight to the animal which belonged to his master, paying no regard to the others which were grazing with it, and brought the beast safely across, both animals being obliged to swim.

By so doing he helped his master out of a scrape; for the kyloe could not have strayed if he had not neglected his dnty by staying in the hut long enough to allow the river to rise.

The same man, when engaged on another farm, had a collie dog to help lim. One day, after the cattle had been driven into the sheds, he found that he must remain for some time longer in order to fodder them. He turned to the dog and said, "I dinna need ye any mair tonight, an' ye had better gang hame noo." The dog perfectly understood him, and went home at once.
"'Ben,' a very fine collie, belongs to an acquaintance of mine, a farmer. One day, as Ben's master was preparing to go to a village at some miles' distance, his wife asked whether he meant to take Ben with him. He answered that he should not do so, and told her to lock up the dog until he came back. Ben, hearing this, slipped out of the house unperceived; and when his master reached the village, lie found Ben waiting for him."

It is evident that in this case the dog must not only have understood that he was not to go, and that he wonld be locked up in order to keep him at home, but that he must have known and recognized the name of the village which his master was about to visit.

"On one occasion when the farmer was going to Berwick by train from the village which has just been mentioned, the faithful Ben had contrived to follow him, and sprang into the carriage just as the train moved off, so that he could not be turned out. The dog attended him all day until his master was about to leave. Time was up, so that he could not wait for the dog, but went off in the train to the station whence he had started, and thence to his home. He had only reached his house for a very short time, when Ben presented himself, all covered with mud, and quite flustered with fatigue, having evidently run the whole distance, some thirteen miles, at full speed."

Reference will be made to this branch of the subject nnder the title of "Love of Master."

A Scotch gentleman has kindly forwarded to me the two accompanying stories, which illustrate the wonderful capacity enjoyed by many dogs of understanding even the minutest of their master's' language:

"A son-in-law of mine, an extensive sheepfarmer in Berwickshire, $\mathrm{Mr}$. G-, of $\mathrm{C}-$, had a collie dog, 'Sweep,' one of the very best of his kind. When, on account of old age, he became unfit for his ordinary work, he was used for taking ont and bringing in the cattle from the parks. He generally lay before the kitchen fire, and, when milking-time came, all that was required was to say, 'Sweep, go for the cows,' when he would at once get up and go for them, bringing them up to the byre without any assistance whatever.

"It sometimes happened that he would leave a cow behind in the field; but whenever he was told so, he would again start off, pick out the cow from among the young cattle, and take her to the byre with the rest. I regret to say that poor Sweep is dead. Without any premon- 
itory symptoms of illness, he was found lying cold and stiff one morning in front of the shepherd's house.

"Some time about the beginning of the century there lired on Clint's farm a man of the name of 'Baldie 'Tait,' a noted sheep-stealer. He had a eollie as accomplished a thief as himself, and there are those still alive who have known lim to direct this dog to go to Heriot Muir, a distance of several miles, to pick out the best sleep he conld get, take them to Hangingshaw, a wayside public-house on the high-road to Edinburgh, and remain with them till Baldie should come, when they were driven to Edinburgh and sold.

"Baldie had become so notorious in his unlawful calling that a warrant was issued for his apprehension. On the day on which he heard of this he went to a sale of farm stock at a plaee called Muircleuch, near Lauder. He as well as his dog were well known; and Baldie, knowing how to improve the occasion, put up the dog to be sold by auction, got ten pounds for it, and decamped at once-not a minute too soon, for in a short time the minions of the law were on his track, but they were too late."

On reeeiving this account, $I$ wrote to the narrator, expressing my surprise that even so great a rascal as Baldie should have parted with his dog. I found, however, that selling the dog was a way he had when he wanted money; for, by some means unknown, he always got the animal back again.

One of my eorrespondents has farored me with a brief history of a dog which understood and obeyed the orders of its master:

"Not many years ago there lived in Edinburgh a drunken, shiftless mole-catcher, of the name of Hastie. Like most of his trade, he was very fond of dogs, especially terriers; and he had one which he loved above all others, calling her his 'blessed Susie.'

"She often used to act the part popularly attributed to the jackal, and provide her master with food. When, as often happened, Hastie was in straits for food, and had no money, he would go past a butcher's-shop, point to a piece of meat, and say quietly, 'Susie, I want that.' He then went on his way, and in a few minutes the meat was sure to be in his possession.

"Time wore on, and, as every thing mortal must have an end, poor Susie became siek unto death. 'The last I heard of the poor waif was, that he was seen with the dying object of his affeetion in his arms, hugging her and pressing her to his heart. The man was weeping like a child, and dreading the swiftly coming moment when he and his beloved Susie were to be parted."

There really must have been a substratum of good in this poor dissipated man, or he never could have eherished or inspired so sincere a love.

I have been rather uncertain as to the heading under which the following anecdote ought to be placed. As the reader will see, it illustrates reasoning and conscience, as well as the power of understanding human language. 'The last-mentioned attribute, however, being very strongly manifested, I have placed the story in its present position. I give the story in the words of the gentleman who kindly sent it to me:

"My grandfuther, Mr. H-, of Gilchristcleugh, in Lanarkshire, possessed a watch-dog of the name of 'Help,' who was usually kept chained up. For some time repeated losses liad taken place among the sheep, some of which were found torn and mangled, but only partially, if at all, devoured. Every effort to trace the secret enemy proved in vain. At last, while Mr. H_— was walking one day on the banks of a little river which flowed at the foot of the pasture hill, his attention was attraeted by seeing his dog, whom he supposed to be safely chained near the house, running down the hill.

"As the dog drew near, it was seen that his mouth and fangs were covered with blood. My grandfather concealed himself so that he might watch unobserred what would follow. The dog walked into the river, dipped his face in the water, and shook his head backivard and forward, until he thought that all traces of his guilt were removed. He then came out at the side next the house, toward which he proceeded, his master following at a little distance. The dog went to his kennel, and, with the help of his paws, put on his collar, which was lying with the chain on the ground.

"My grandfather walked up to him and said, 'Help, my poor fellow, there is no help for you.' He then went away, and gave the necessary orders for the dog's execution. But when the servant came to lead him to his doom the collar was once more empty, and 'Help' was never more heard of in the county."

It is plain that the dog must have perfeetly understood the meaning, if not the exact words, of his master's speech.

No reproaches had been used; but he felt himself detected, and understood that he would have to suffer for his crime if lie did not abseond.

Another story of a very similar eharacter was 
sent to me, but I have mislaid the MS., and can not remember the name of the narrator.

A gentleman had an old $\log$, which was so weighed down with the many infirmities of age that his master thought that the kindest treatment was a quick instead of a lingering death. Accordingly, he asked a medical friend to bring some poison. 'This he did, and, laying it on the table, said, without mentioning the dog's name, "That is the stuff which will do his business." The dog was at the time in the room; but soon afterward his master noticed his absence, and inquired abont him. No one had seen the dog, and no one dil see him again. In some mysterions way he had conjectured the object of the visitor, and had withdrawn himself, probably to die in some hidien spot, as is the way of all animals when they feel that the thread of life is being loosened.

INere I may observe that nothing wonld induce me to poison a dog, or allow it to be poisoned, except by a competent person who would administer a dose of prussic acid. Strychnine and arsenic, which are the usual poisons employed for killing dogs, cause horrible agony before death. Hanging and drowning are each objectionable, as the life is extinguished by degrees instead of suddenly, as ought to be the case. A bullet or a charge of shot through the brain is by far the most humane mode of destroying life, as the great centre of feeling is instantaneously crushed, and there is no time for even the slightest sense of paill.

In the story narrated below it is evident that the dog perfectly understood the words of his mistress, for he did violence to his own fcelings, and obeycd the wish which his mistress conveyed in her rebuke. A thoughtless child, if reproved for a similar action and beharing in the same manner, would be held to liave acted in a way that became a being possessed of an immortal soul.

A lady, who is a thorongh appreciator of animal character, writes to me as follows on this subject :

"Dogs perfectly understand human language when refcrence is made to them, even though the words are not directed to the dog personally. If my little dog ever heard me make a plan in which he was to be left at home, while I was to go somewhere without him, 'Nettle' invariably set to work to counter-dodge me, and often got his own way in consequence. It was impossible to resist his queer, elfish determination.'

We knew a dog named "Bijon," a thorough- bred Spitzberger. The honse in which he lived was one of a terrace with a verandil ruming throughout its whole length, only separated by a wooden railing at each house. 'This reranda was Bijou's farorite resort; here he carried his chicken bones, and here contemplated the proceedings of his neighbors.

"One day a half-starved dog spied one of his bones lying about, carried it to the mat at tho door of the next house, and began eagerly to devour it. Bijon saw the theft from the window, sprang out with a threatening growl, carried off the bone, and replaced it on his own mat.

"Iis mistress, who had been watching the action of the dogs, said to him, 'Oh, yon greedy dog! Yon can eat 110 more, and that poor dog is starving.' Bijou at once picked up the bone of contention, carried it to his starving fellow, laid it before him, and retired to his own honse, from the window of which he contemplated, with a benign aspect, the disappearance of the bone."

The following letter, which was sent to me by the Honorable Grantley F. Berkeley, illustrates the individuality of character to be found in dogs, the love which they bear townd their master, and their knowledge of man's language:

"'There was in my pet greyhomd 'Brenda,' there was in my dear lurcher 'Smoker,' and there is now in my dear lurcher 'Bar,' and in my three setters 'Chance,' 'Quail,' and 'Quince,' a refinement of feeling and sagacity infinitely beyond that existing in multitudes of the human race, whether inhabiting the deserts or the realms of civilization.

"I can not better define it than by saying that, if I give these dogs a hastily angered word in my room, though they have never been beaten, they will, with an expression of the most dejected sorrow, go into a corner behind some clair, sofa, or table, and lie there. Perlaps I may have been guilty of a hasty reluke to them for jogging my table or elbow while I was writing, and then continned to write on. Some time after, not having seen my companions lying on the rug bcfore the fire, I lave remembered the circumstance, and, in a tone of voice to which they are nsed, I have said, "There, yon are forgiven.' In an instant, the greyhound Brenda would fly into my lap and cover me with kisses, lier heart tumultuously benting. After she grew old, her joy at my return home after a long absence has at times nearly killed her; and when I was away, the bed she lored best was one of my old shooting-jackets, but never when I was at home.

"Had I time, I could look up many an in- 
stance of soul, in some senses of the word; but I have not."

Here is another of a physician's reminiscences, showing that dogs can exchange ideas with human beings, and understand the language of mall :

"Having been much taken with the intelligence, faithfuhness, and beauty of a terrier belonging to a coachman whose family I attended, I purchased three of her pups for myself and two friends.

"Shortly after" this the conchman and his family moved to a new house, where they had no friends. His wife was takel suddenly and seriously ill, and could not stir from bed. The dog lay constantly at her feet, and never moved till the door was opened, when off she set in great haste. She went to the house of the suffering woman's parents, made a great and unwonted noise, and often went to the door, even laying hold of the woman's gown.

"The animal never rested until she followed it, when it manifested every token of approbation, as it looked around from time to time. It went straight to her daughter's house, when the real cause of the strange conduct of the dog was understood. The dog resumed its place, and scircely left it for a moment until its mistress recovered. I then said, "Now, "Missy," you may come with me,' when she went all her round with me, and returned home after dinner. This was repeated several times.

"The dog seemed really to understand many things you said, and even to forestall your wishes."

In this interesting story we find in an animal a singular aggregation of faculties which are held in man to belong to the immortal, and not to the mortal part of his being. There is reason, $i . e$, the deduction of a conclusion from premises. There is the power of forming ideas and communicating them to man, and the capability of understanding man's language, and, as the writer says, even of anticipating the wishes of her human friends. Lastly, there is the intense love for her mistress, combined with the power of self-sacrifice, which enabled her to keep her irksome watch by the sick-bed while her instinct was urging her to take her accustomed exercise in the open air.

The cat which is mentioned in the following anecdote is the mother of Tiny, whose exploit with a lobster has been previously narrated. 'The writer is Lady $\mathrm{E}$ ——. The reader will see that it illustrates two subjects: first, the fact that the cat understood human language; and next, that she could make her message understood by a human being.

"After my great loss, whenerer I was left alone in the room, 'Rosy' usually placed herself on the table beside me, and watched my countenance most earnestly.

"About this time, my sister, who was living with me, had been some time in her room, and, wishing her to come to me, I said, 'Rosy, go upstairs and tell Augusta that I want her.' The cat immediately jumped from the table, ran upstairs to my sister's room, leaped upon the chest of drawers by which she was standing, and, putting her paw on Augusta's hand, mewed, then hurried down-stairs, mewing and looking around. This proceeding, Angusta could not mistake, was intended to call her down-stairs; so she followed, and asked if I wanted her, as Rosy had been to call her. Rosy appeared delighted at being mnderstood, and purred with satisfuction." 


\title{
CHAPTER VII.
}

\author{
MEMORY.
}

Memory versus Materialism._Connection of the Brain with Memory.-The Workman and his Tools.-Memory in the Insects.-The Tame Butterflies.-Sir J. Lubbock's Tame Wasp._Bees and Wasps find their Way by Memory, not by Instinct._Comparison witl Human Beings under Similar Circumstances.Memory the Means by which Animals, as well as Men, are Capable of being Taught.-Two Tame Moles which would Come when Called.-A Partially Tamed Tiger-cat.-Memory in the Water-hen and Cockatoo.-The Power of Memory among Poultry.-Memory in the Ass._ "Donald," the Galloway, aud his Long-lost Friend.-Memory of the Wolf.-Rarey versus "Cruiser."-Memory in the Cat._"Fan," the Blenheim Spaniel.

I sHould think that Memory must be rather a hard nut for materialists to crack. What is that which survives, though every particle of the material brain las been repeatedly changed? What is that which more or less deeply receires impressions and retains them through a long series of years? And even when they seem to be forgotten, they are often but hidden behind a temporary veil, which at the touch of a passing scent in the nostrils, a dimly heard sound striking upon the ear, the waving of a branch, or the nodding of a flower, appealing to the eye, is in a moment rent asunder, and scenes long forgotten are reproduced before the menory as vividly as though time lad been annihilated. Nothing is omitted; but there comes a minnte and instantaneons insight into every detail, that gives us some faint idea of the omnipresence and omniscience of the Creator, to whom space and time are absolutely as nothing. For a moment we escape from our fleshly tabernacle, and we see and hear with our spiritual and not with our material organs of sight and hearing.

As to ourselves, we expect that we shall retain our memory, and carry it into the next world. We expect to recognize in the spiritual world those whom we have loved on this temporal world. Memory, therefore, must be spiritual and eternal; and wherever memory can be found, there is an immortal spirit. Apart from Revelation, which we have already considered, there is no stronger eridence of a future life of man than memory, and, in pure justice, if we apply this proof to ourselves, we ought to apply it wherever memory is found.

Some have said that memory is a mere emanation from the brain, and have tried to prove their point by asserting that which no one ever denied, that an inferior brain is coupled with an inferior intellect, that if the brain be injured by any cause all the powers of thought are weakened, and that if it be seriously damaged all powers of thonght are utterly in abeyance.

All this is true enough, but it affords no proof that thought is the creation of the brain. On the contrary, the brain is the organ or instrument of the thought-power, and stands to it in the same relation that a tool does to a carpenter. Howerer good an artisan a carpenter may be, he can not turn out good work with a blunt tool, nor any work at all with a broken one. So it is with the brain: it is but the tool of the spirit, and, if it be injured in any way, the keenest intellect will be unable to work with it.

Moreover, memoly exists in creatures which have no brain at all. Take, for example, the insects, which have no real brain, but only a succession of nerrous ganglia running along the body, and in many of them we shall find the faculty of memory very strongly developed.

Some ten years ago, I gave, in my "Glimpses into Petland," published by Messrs. Bell \& Daldy, an account of two butterflies which had been tamed by a lady. One of the very critical weekly papers was good enough to treat the whole story with scorn and derision, saying that $I$ gave it as from a lady, and thereby insinuating that the account was a willful imposition on the public. The story had been told to me by the lady in question, whom I have known for many years, and at my request she gave it in writing.

Here is the story, as published in "Petland:"

"Among the many pets that $I$ have loved and lost, few have endeared themselves more to me than my butterflies, two of which I once kept for the space of a year and a half.

"They came into my possession when in their 
chrysalis state, and I, not knowing any thing of entomology, shut them up for safety in a cabinet having glass doors. 'The cabinet stood near a small window in my bedroom. I was very $\mathrm{mll}$ well that winter, and therefore a fire was kept up in my room night and day. Therefore the room was very warm, and I suppose that the little butterflies were deceived thereby, and thought or dreamed that summer sniled upon the earth; for, a few days after Christmas, to my astonishment and delight, a little yellow butterfly was seen fluttering feebly within the cabinet.

"My attention was first diverted to the eabinet by the playful gambols of a pet pussy, who had mounted on a chair, and stood upon its hind legs, parving at the little creature through the glass. I soon sent pussy away, opened the cabinet, and tried to induce the butterfly to alight on my hand. But it was either dazzled and bewildered at finding itself in its new and extended sphere of existenee, or had already learned the fear of man; for at the approach of my hand it flew wildly about, and finclly settled down as if exhausted.

"I now became most anxious to feed the little thing; but how this was to be aehieved I had not the slightest idea, nor could any one in the house advise or leelp $\mathrm{me}$ in this important matter. Moreover, I was londly ridiculed for the bare idea of trying to tame and feed butterflies.

"However, I remember that the poets all agreed in saying that butterflies sipped nectar from the opening flowers, and therefore turned my attention to the mamnfacture of a substitute for neetar; so, having obtained some honey, which I diluted with rose-water, I put one drop into the centre of the open blossoms of a fairy rose, and placed the little plant in the cabinet. I soon liad the joy of seeing the little thing flutter around the rose, and finally settle upon it.

"Whether it really drank or not, I can not say. I thought that it must have done so, as it appeared to grow stronger and more lively every day. I fed it in this manner for a fortnight; and by the end of that time it became so tame that it would step off the flower or any thing else on which it might be standing, and appear quite happy and at rest upon my hand.

"It also appeared to understand that I wished it to come to me when I called it by the name of 'Psyche,' that being the name whielı $\mathrm{I}$ had given to the insect.

"About three weeks after" the advent of Psyche we were gladdened by the addition of another butterfly to our establishment-a peacoek. He was strong and vigorous from the tirst, and flitted swiftly about, like a beam of prismatic light. I used to faney that they talked to each other, as he at once fell into the ways and labits of the other; and when I ealled Psyche, he too would come. I gave lim another name, but he never seemed to understand that it belonged to him.

"They lived in this way until the earth had donned her glowing summer robe of lilies and roses, when I was told that their life-power could only extend over a month or two, and that it was cruel even to keep them as happy prisoners. I was therefore induced to give them their liberty. The eabinet was plaeed with open doors before the vindow.

"It was many days before the butterflies ventured to leave the window-sill, and this mueh to my joy, for I thought that it might be affeetion for me that held them back. However, one day, with many bitter tears, I saw them depart and join some wild eompanions; but at night we found them again in the cabinet.

"On the following morning they left us, and came not back again until the cold and stormy September weather set in.

"Yet, when in the garden, they would come if I ealled them, and rest for a short time on my hair or hands. At length, on a eold, windy day in September, we saw them on the window-sill, and, on our opening the window, they came in and resumed possession of their old quarters, and abode there for the winter.

"It is true they were but poor-looking objects to what they were when they went forth. The world seemed to have used them rather roughly, for the sheen had gone from the rich wings of the peacock butterfly, and the soft yellow bloom from Psyche's plumage. Nerertheless they were welcome guests; and, tlough ragged and wayworn, were not the less loved.

"We observed that during this winter" they slept nore than they did formerly. They also manifested pleasure when sung or talked to, and were very fond of being waved about and danced up and down in the air, while they would sit upon the hand quite calmly. I think that the movement must have reminded them of the nodding flowers and fresh breezes of their summer life.

"The sun and earth ran their appointed course until they brought us to another bright June, and again I bestowed the boon of freedom on our fairy pets, who went forth gayly; but, alas! never to return. One day, after a heavy thunder-storm, we found the inanimate form of a yellow butterfly upon the window-sill. I took it up lovingly, and did my best to revive it; for I beliered it to be the material form of my orn beautiful Psycle, who had sought refuge from the storm, but found the window closed. Of this I can not be sure, 
for all our efforts to restore her were in rain. The wondrous essence that had given it life, beauty, motion, affection, and memory had returned to the hand of its mighty Creator; and witlı him let it rest.

"The peacock butterfly never returned: whether he fell a victim to that aerial shark, the dragon-fly, or died of age, sickness, or forgot lis early friends, I know not.

"I have since tried to tame other butterflies, but never was so successful, although I have taught three or four to know me and to come at iny call. Indeed, circumstances lave never been so farrable; for I never had any other butterflics in their chrysalis state, nor have a room and a cabinet been ready to receive them."

'There are one or two points to be noticed in connection with this story. The first is, that the narrator, as she says, knew nothing of entomology. She was not aware that the yellow butterfly was our common "brimstone," and the socalled peacock butterfly was in reality a "small tortoise-shell," these being the earliest and the hardiest of British butterflies, the "brim-stone" being almost invariably the first butterfly to be seen, while the "small tortoise-shell" follows it after a short interval. I was much puzzled at the description as given in writing, and it was only by getting a description of the so-called "peacock" butterfly vivê voce that I was able to identify the insect. She did not know how a butterfly fed itself. She knew nothing of the hibernation of these insects, and yet if a practiced entomologist had written the story, it could not have been more accurate in these scientific details.

But if the reviewer will not believe the account written by a lady, although authenticated by myself, he may believe Sir John Lubbock's account of a far more difficult task, namely, the successful taming of a wasp. Here is the story in his own words :

"Dear Sir,-In answer" to your inquiries, I beg to send you the following particulars about my poor wasp:

"I took it, with its nest, in the Prrenees last May. The nest, which was beautifully regular, consisted of about twenty cells, the majority of which contained an egg; but as yet no grub had been hatched out, and, of course, my wasp was as yet alone in the world.

"I had no difficulty in inducing her to feed on my hand; but at first sle was slyy and nervous: she kept her sting in constant readiness, and once or twice in the train, when the official came for tickets, and I was compelled to hurry her back into her bottle, she stung me slightly-I think, howerer, entirely from fright.

"Gradually she bccame quite used to me, and, when I took her on my hand, evidently expected to be fed. She allowed me to stroke her without any appearance of fear, and for some mouths I nerer saw lier sting.

"When the cold weather came on, she fell into a drowsy state, and I began to hope she would libernate and smvive the winter. I kept lier in a dark place, but watched lier carefully, and fed her if ever she seemed at all restless.

"She came out occasionally, and scemed as well as usual till near the end of February, when one day I observed that she had nearly lost the use of her antennæ, though the rest of her body was as n1sual. She would take no food. Next day I tried again to feed her; but the head seemed dead, though she conld still move her legs, wings, and abdomen. 'The following day I offered her food for the last time, but both head and thorax were dead or paralyzed; she could but wag her tail-a last token, as I could almost fancy, of gratitude and affection. As far as I could judge, her deatlu was quite painless; and she now occupies a place in the British Museum."

The reader will see that, in both these examples of tamed insects memory was absolutely indispensable, and that without the existence of this faculty it would have been impossible to influence them with human ideas.

As to the wasps, the late $\mathrm{Mr}$. Stone, who had made them his special study, told me a portion of these insects' life-history which proves the existence of memory. We were speaking of the "homing" faculty of various animals, especially pigeons, bees, and wasps, and were debating whether the faculty were due to instinct or reason. Mr. Stone gave his decided opinion that all those creatures were guided by reason, the insects as well as the birds.

He said that any one who was accustomed to the ways of these insects could tell by the manner in which a wasp left the nest whether it were an old or a young one. An old wasp crawls to the entrance of the nest, and at once darts off without any ceremony. A young one, however, when going out on its first expedition, acts in a very different manner. When it has emerged from the entrance, it turns round and examines the spot; it then takes to wing, but flies backward and forward in front of the nest, and always looking toward it as if taking notes of the bearings, and gradually increasing its distance until it is out of sight.

Here, then, is a distinct exercise of memory as well as of reason, the creature impressing on its 
mind the appearance of the objects near its nest, and acting on the result of those impressions. Human beings act in just the same way when traversing for the first time a locility through which they will have to returm. And yet, as I have already stated, the wasp has no true brains.

Mr. Stone remarked that he has seen bees act in a similar manner when their hire has been inoved to a spot at any distance from that which it formerly occupied.

We will now pass to some of the higher animals, taking, first, one or two examples of creatures that are not usually subject to domestication, and can therefore have received no teaching by means of their parentage.

By means of this faculty almost any living being is able to be tanght by man, while, if memory were absent, no teaching would be of the very slightest use. 'The mole, for eximple, seems to be about as difficult a subject as can well be imagined, and yet $I$ knew of one case where a mole was perfectly domesticated, and another in which it was partially tame.

The former was a specimen of the albino, or white mole, a variety which is tolerably common. It was living at St. Malo, in 1856, and the story of its life was told to me in 1857.

It knew its name, would come to its master when called, and had learned to perform some little tricks: for example, when told to do so, it would tumble over on the table, and would fetch coins if they were scattered within its reach. The animal had a curious preference for silver orer copper coins, probably becanse the sensitive nerves of the mole were affected by the copper. It always ran faster, and seemed more pleased when it had a silver coin in its mouth than when it had been dispatched after a copper coin. What it might have done in these days of the light bronze coinage, I do not know.

The second example of a tame mole was one of the common brown animals, which had got into a garden, and was doing much damage. The gardener, being practical and not asthetical in his tastes, did his best to kill the mole; but the inhabitants of the house, being xsthetical rather than practical, tried to tame the animal, in which they partly succeeded.

The aperture by which the mole usually came into the open air was situated under a sage-bush, and near the opening a piece of raw meat was litid. The delicate organs of the mole soon perceived the supply of food, and the animal, after he laad finished his meal, camc to look for some more. 'This was given him, accompanied by the sound of his name, "Barty," an abbreviation of
Bartimens. Sometimes the mole was too fur away from the aperture to hear his name, and in these cases a measured stamp npon the ground. was sure to bring hin to his meal.

Here is an instance of the influence of memory upon an animal which is not often tamed, and which in this case hrippened to be a peculiarly fierce and sullen individual.

Some years ago I was a constant visitor to the Zoological Gardens, and used to make acquaintance witl the various animals as far as they would allow ne to do so.

One day I was struck with the beauty of a very large and beautiful ocelot, or tiger-cat; but the animal secmed to be a new-comer, and was very wary and fierce, declining to respond to any overtures that were made. At last, when standing by the cage on a hot summer's daty, I thought that I saw a mode of getting at the animal's feelings. The place quite swarmed with flies, mostly blue-bottles, a few of which occasionally got inside the bars of the cages. Seeing the ocelot try to catch one of the flies, I captured a fine large blue-bottle, and held it close to the bar's so as to make it buzz, and waited quietly. After a while the ocelot came cautiously up, and, after one or two feints, took the insect and ate it. I immediately caught another, and offered it in the same way, giving a low whistle at the time. This time the ocelot took it without mnch difficulty, and in half an hour or so he came at once to the whistle, and took the fly.

On the next visit I repeated the proceedings, the ocelot perfectly recognizing me; and after one or two risits, the beantiful creature would press itself against the bar's to be caressed, and to have its nose and chin rubbed, just as does a favorite cat. The keeper happened to come in while I was talking to the ocelot, and was quite alarmed, saying that even he did not dare to trust his fingers between the bars. Now the keepers are specially kind and gentle toward the animals under their charge, and can do wonders with the fiercest of animals; so that for a keeper to be unable to trust his himd in a cage, shows the ferocity of the animal confined in it. I fully believe that in this, as in most other cases wherc an animal is ferocious, fear, and not ill-temper, is the real cause of its conduct.

'The following account of a tame water-hen was sent to me by the owner of the house-a lady well known in the literary world :

"Some five or six winters ago two water-hens made their appearance in the mountain brook which runs through our lawn, and were con- 
stantly to be seen upon the grass. One was itself vehemently to its nurse, and used to follow larger than the other, of a deeper color, and we her over the house, calling her anxiously until supposed them to be a pair. 'The winter was seated in her lap. I shall presently liave to tell exceptionally severe; there was more snow than several aneedotes of poultry, but under a differusnai, and when it melted the smaller of the ent heading, so eonfine myself to one which was two was found dead. The other remained until sent to me by the ehief actor:

March, when it disappeared. During its stay it had learned to come toward the dining-room window while the pea-fowl were being fed, and, if food were thrown to a little distance, would pick it up.

"The second week in the October following it again made its appearanee, and remained through the winter, becoming tamer every day. At last, whenever it heard the window opened, it wonld hasten, half rumning, half flving, to be fed. Every year it has appeared and disappeared with as much regularity as the swallows, and always about the same day of the same month. Now as soon as it arrives it is perfectly tame, and eomes rumning up as soon as the sound of the opening window is heard.

"I always feel sorry when the time of its departure arrives, and gladly welcome its return. It has never laal a companion, but it must leave for the purpose of getting a mate. Yet it never brings one liere, nor have I ever seen another water-hen within miles of this place."

Here is a good example of memory in the case of a domesticated bird:

"Our noble yellow-crested cockatoo was the especial pet of the eldest daughter of the house. The young lady married an officer, and was absent from the old house for nearly three years. Her anticipated advent on a visit to her father was of eourse talked about, and we may imagine the eockatoo prieked up her ears at the sound of her name. The moment the carringe stopped at the door she flew down from her perch, and, before namma or sister eould greet her arrival, was outside the fiont door with 'Kiss me, my dear' kiss me, $\mathrm{Sa}$; kiss me, Sa." "

Why it should be I can not tell, but our domestic poultry are sadly neglected in the way of human education; and yet that they are perfectly capable of receiving it, if properly given, I am quite sure, having seen many instances in whieh poultry of various kinds have preferred the companionship of man to that of their own kind. I knew personally a elieken and a duek who entirely repudiated their proper companions and domicile, preferring men to birds, and the drawing-room to the poultry-yard. The chicken had been an ailing little ereature; and being earefully tended until its restoration to health, attached

"I am no poultry-fancier, being perfectly ignorant of the distinetion between Bralımas, Coehins, etc. We have only a few faney bantams.

"During the last illness of a favorite ridinghorse I was a frequent risitor to her stable; and one wintry morning, after a snow-storm, one of these tiny bantams looked so eold and pitiful that I put it on my hat, and thus transferred it to the warm stable. I never could find mneh intelligence in the poultry tribe; but this little bird, which I named 'Jemny,' found the elimate of the stable so enjoyable that, in order to obtain an entrance, it watehed my risits, always flying up to my hat directly I approached.

"Mimiery is the gift of monkeys, but I know that fowls are endowed with it. Jemmy had some little brothers and sisters, who followed his example. Not wishing to aeeommodate the whole family on my hat, I made it my custom to push the others off. Onee, by mistake, I pushed off Jemmy, who made me aware of the faet by a great cacophony, and resented my unintentional rudeness to sueh an extent that it was many days before I conld obtain his forgiveness, and induce him to resume his high position. Once I entered while wearing a bonnet: his efforts to obtain his nsual comfortable footing were most absurd, and at last he descended in great disgust at the alteration."

$\Lambda$ s for anecdotes of the domesticated animals, such as the $\operatorname{dog}$, the eat, the lorse, and the ass, there are so many that I am obliged to restriet myself to a very few. Indeed, every one who has had personal experience of these animals must have remarked the great strength and endurance of their powers of memory.

The following story is by the late Rev. Cæsar Otway, and is told in his lecture on the "Intellectnality of the Domestic Animals:"

"I shall tell you what I know of an ass. There is a lady resident in a parish where $I$ was for some years minister. She is the most tender-hearted of the human race; her tenderness, though a general feeling, is principally eonfined to the lower animals. I am disposed to think that if in India or Turkey, she would leave all her worldly goods to endow a hospital for deserted, disowned, and abused animals.

"Well, this lady was walking along the road, 
and sle met a train of tinkers proceeding toward Connanght and one tall, tan-skinned, black-haireu, curly-polled fellow, in all the excited cruelty of drunkenness, was belaboring liis ass's sides with a blackthorn cudgel. 'This was too much for iny friend. She first rated the man for his barbarity : she might as well hive scolded Bcelzebub. She then coaxed the ruffian, and asked him if he wonld sell the creature, which lie consented at once to do, asking, of course, three times the proper price. You may judge of the joy of this amiable woman when the beast, now her own, was relieved from its pamiers, allowed to roll about in the dust, and graze at liberty.

"For" a long time she kept him perfectly idle, until he recovered his spirits; then he became troublcsome, and would break his bonds, and used to go a-braying and curveting, and seeking for asinine society all over the country. Idleness is certainly, after all, a bad thing for asses as well at: men, and so this capricions fellow found it; for shortly a tinker, perhaps the very one that sold it, stole it, and for three or four year's there wcre no tidings of the ass, until one day, as his kind mistress was taking her usual walk along the road, she saw a man urging along an ass straining and bending under a very heary cart.

"Now the moment my friend eame near there was an alteration in the deportment of the ass; immediately the ear's that were but just now lianging listlessly over its eycs were cocked, and its head elevated in the air; and, raising its voice more like a laugh than a bray, it urged itself mder its heary load into a trot, and came and laid its snont on the shoulders of the lady, who at once, and not until now, recognized her long-lost property, which she had again to purchase at a high price. It is many year's since that occurred; the beast is alive, and so is the lady. I hope it won't be her lot to see in it that rare spectacle, a dead ass."

An adventure of a nearly similar nature occurred to the gcntleman who furnished the acconnt of the miller's dog at Maxwellheugh, and who has kindly taken a great interest in the object of this work:

"When I was a boy, my father bought from a neighboring farmer a gray Galloway pony, who was rely vicious to all with whom lie came in contact except myself. The way in which I acquircel so much porer orer him was by feeding him with bread, and showing him other acts of kindness.

"Some ycar's afterward I left home, and when I returned to my father's house I found that 'Donald ' had been sold, and that all trace of him E had becn lost for about seventeen years. At that period, being resident in a village in a neighboring county, I saw an old white horse in a cart, and thinking that it might be the sane animal, I went up to him in the same way as I used to do in boyhood, and said, 'Donald.' He immediately turned his head to me, laid it on my shoulder, pawed the ground, rubbed his nose upon my arm, and showed the greatest possible affection.

"The driver of the cart came out of a shop, and warned me to kecp away from the horse or he would bite me. I moved ip the street, when Donald became restive, wrenched the reins out of the lad's hands, followed me along the street, and it was not until I entered a house that, after much difficulty, he was induced to move away."

This is a really wonderful act of memory on the part of the horse, and not at all a bad one on the part of the man; and the incident affords a dircet proof that memory is a common possession of man and bcast. That the man should recognize the animal which he loved in his boylood was a tolerably fuir exercise of memory; but that the horse should recognizc the man is even more astonishing. From boyhood to manhood, the lapse of seventeen years makes such changes in personal appearance that, as a rule, the man of thirty can scarcely be recognized eren by those who knew him well as a boy of thirtcen. Nor can the voice give any help in recognition, for the deep tones of the manly voice are as unlike the shrill sounds of a boy's "treble pipe" as is the bcarded face of the man to the smooth cheek of the boy.

Dress also makes a great difference in the appcarance of a human being; and when we consider that the dress of a man is quite mulikc that of a boy, we must appreciate the strength of memory which enables the horsc to recognize his friend in spite of so many alterations.

Anecdotes of a similar character are plentiful, and even the wild beasts arc known to remcinber a human fricnd after a long lapse of ycars. In Iardwicke's Science Gossip of October, 1871, there is an accomt by Mr. W. W. Spicer of a wolf at the Zoological Gardens at Clifton with which he struck up a friendship. He was forced to lcare Clifton for some two year's, and on his return went to see his friend:

"I at once set to work to test the wolf's affection and retentiveness of mcmory by whistling in a low tone at as great a distance from the dcu as allowed my watching its morcments. At the first sound, the animal, which before was 'loufing' abont in a listless manner, raised its head and listened; and on my continuing to whistle, it 
bounded against the bars with every mark of joy.

"Long before I reached the cage he recognized my footsteps, and strove to engage my attention by whining and throwing himself into all kinds of queer positions. My welcome, in fact, was of the warmest kind, and I left him with, I was going to say, mutual expressions of sincere regret; for if ever an animal gave expression to its feelings, it was this poor wolf, who recognized me after so long an absence."

These anecdotes fully corroborate the opinion which I have always held with regard to the relationship between man and beast. The latter was intended to serve the former, and there is nothing in the hands of man half so powerful in educating the lower animals as thoughtful kindness. Inflexible decision, combined with gentleness and sympathy, are irresistible weapons in the hand of man; and I do not believe that there is any animal which can not be subdued if the right man undertakes the task. By this mixture of firmness and kindness that raging wild beast of a horse, "Cruiser," was in three hours rendered gentle and subservient, obeying the least sign of his conqueror, and allowing himself to be freely handled without displaying the least resentment.

I once saw Mr. Rarey operate on a splendid little black Arab horse that flew like a tiger at him, kicking, biting, and screaming at once, now attacking with his jaws, and now with his heels. He might as well have attacked his own shadow; for, just as the Spanish bull-fighter absolutely plays with the furious beast in the circus, so Rarey seemed to play with the animal, stepping quickly on one side as it made its rush with open mouth, and then, as it spun round and lashed out with its heels, being on one side, just out of reach.

Within half an hour Rarey and the horse were lying together on the ground, Rarey's head resting on one of the hind hoofs, and the other hoof being laid on his temple. He then got up, mounted the animal, dismounted by sliding over its tail, and finally, with hands in his pockets, ran round the eircus, the horse's nose resting on his shoulder. He had impressed upon the animal's memory that no har'm was intended; and so the horse, instead of feeling fear and anger, conceived an affection for the man who inflicted no pain, and yet showed that lie must obeyed.

The following anecdote of a eat demonstrates several traits of character which are common both to man and beast. I was rather doubtful under which head it should be classed; but as it illustrates the present subject, I have placed it here:
"I confess myself a great friend and admirer" of horses and dogs, but care little for cats in general, although, when away from home pets, I often make playthings of them. Did you ever know a landlady without a cat, visible or invisible? We had rooms in Berkshire, and the morning after our arrival, on cntering the dining-room, I saw a real, visible cat sitting on our breakfast-table, and reducing the quantity, if not the quality, of the milk. The milk-pot being narrow at the top, she obtained it by putting in her paw, curling it round, and then lapping it up. (Animals, are never afraid of me, nor do I wish them to bo so.) I allowed Puss to continue her depredation on the milk; we breakfasted without it, and her theft remained unpunished.

"After we had been there some time, Puss listened every morning until I rang for the teakettle, which she always accompanied to the breakfast-table. One morning I was later than usual, and while dressing I was surprised to hear the eat mewing at the bedroom door. As she liad not before done so, I let her in, with the remark, 'Puss knows I am late, and is waiting for her breakfast.' I was, however, quite mistaken : she was too ill to eat, but came to me for that sympathy which she could not obtain from otlers. After our departure no one eared for the poor animal; she was first neglected, and then killed for being delicate. She was such a gentle and affectionate ereature that I would have taken her to my own home if I had known her impending fate."

Here are several mental characteristics exhibited by the same animal. Her reason taught her to get the milk out of the jug with her paw when she could not reach it with her tongue. I know a very intellectual eat, the grandmother of my own lamented "Pret," who would steal bottled porter in the same way. She would not take milk, but porter had a fascination that she could not withstand. Then this cat's memory retained the recollection of kindly treatment; and so she not only became partaker of the daily meal, but asked and obtained loving sympathy when she felt herself ill. A child who had been kindly treated wonlu have acted in precisely the same manner.

Another instance of reasoning and memory brought to bear on sickness has been communieated to me by a friend:

"As illustrative of memory, take the following anecdote: A pet Blenheim spaniel, 'Fan,' had had two or three litters. At the birth of the third or fourth family (who were all dead born) she was extremely ill for some days, refusing ev- 
ery thing in the shape of nourishment, till by dint of much coaxing and petting she took captain's biscuits, and lired on them solely till quite convalescent. In succecding accouchements she refused all othcr food till her master thought of the biscuits. When offered, they were immediately eaten with avidity, and she kept to that particular diet forever afterward when nursing."
In all these examples of memory, the reader will probably have remarked that there must be something more in this faculty than a mere production of a material brain. In several cases there was no brain at all; and in others, where a brain did exist, its material particles must have been repeatedly changed, while the ideas impressed upon the memory still remained in full force. 


\section{CHAPTER VIII.}

\section{GENEROSITY.}

Different Senses of the Word Generosity.-Firstly: the Sense of Liberality.-Two Grateful Cats._"Pret" and his Mice.-Pret Eutertaining his Friends.-Generosity Before Justice.-Another Grateful Cat.The Cat Providing Mice for Two Sea-gulls.-The Retriever "Nellie" and her Cat Friend._-"Barbekark," the Esquimau Dog, and the Reindeer.-His Self-denial and Power of Command.-The Generons Sparrow.-Secondly: the Sense of Magnanimity, or Indisposition to Resent an Injury, though Possessing the Power to do so.-Might and Mercy Convertible Terms.-Anecdote of Cribb, the Prize-fighter.- "Lupo" and his Little Friends.-A Dog Fighting Himself into Favor.-My Bull-Dog "Apollo" and the Retriever.

Is whatever sense we take the word which heads this chapter, i. e., whether we aceept it as signifying liberality or magnanimity, the quality is acknowledged to be a very lofty one, and one which infinitely ennobles the charaeters of those who possess it.

Take the former sense of the word.

It is, in fact, an attribute of God himself, who gives us frcely all that we possess, and so sets us an example of generosity to our fellow-creatures. That we recognize this as a fact is shown by the extraordinary number of disparaging epithets and nicknames which are employed in designating those human beings in whom generosity is more or less wanting. Miser, skinflint, churl, screw, muck-worm, curmudgeon, serimp, liek-penny, etc., are among the nicknames bestowcd upon such unfortunate persons; while among the epithets are such flowers of speech as stingy, shabby, mean, parsimonions, hard-fisted, sordid, covetous, niggardly, and a host of similar terms too numerous to mention.

Now if it be admitted that the possession of generosity ennobles man's character, while the lack of that quality debases it, we ought not to deny the plain inference that when we find a beast possessing generosity, and a man devoid of it, the beast is in that partieular not only the equal but the superior of the man. And that generosity, being a divine attribute, belongs to the spirit and not to the body, I should presume that no one who belieres in Christianity is likely to deny; so that whererer we find this characteristic developed we must admit the presence of an iminortal spirit.

I will now produce a few authentieated anecdotes in order to prove that the lower animals do possess generosity in the sense of liberality, several of the eircumstances having oeeurred within my own observation, and the others being authenticated with the names of the writers.

With regard to the sense of generosity and gratitude which can be developed in the cat, the following anecdote was related to me by a friend of the owner of the animal :

The cat had some kittens, and one of them was taken ill, and was apparently in a dying state. The mother did all that she eould for it ; and then, finding all her efforts useless, brought the sick kitten to her mistress, laid it in her lap, and left it in her care. The lady accepted the charge, nursed the kitten through its illness, and at last was able to give it back to its mother quite restored to health.

Some time afterward the lady herself was seized with illness, and was unable to leave her bed. By some mysterious means, whether by mere instinct or by gathering the meaning of the conversations around her, the cat became arvare of her mistress's illness. Finding herself unable to enter the room by the door, she contrived to climb up the wall of the house, scrambled in at the window, jumped on the bed, and laid on the pillow a mouse, as an offering of affection and gratitude.

Sinee I began to write this book I have received many anecdotes of a similar character, and in nearly all, if not all of them, gratitude was the existing cause of the animal's generosity. Indeed, I could easily have made a separate chapter on the subject; but not wishing to multiply chapters, I have included them under the present heading. Here is a story which appeared in Good Words for December, 1873 :

"A cat in a Swiss cottage had taken poison, and came, in a pitiful state of pain, to seek its 
mistress's help. The fcrer and heat were so great that it dipped its own paws into a pan of water-an almost unhcard-of proceeding in a water-hating cat. She wrapped it in wet linen, fed it with grucl, nursed it, and doctored it all the day and night after. It levived, and colild not find ways enough to show its gratitude. One erening she had gone up-stairs to bed, when a mew at the window roused her. She got up and opened it, and found the cat, which lat climbed a pear-tree nailed against the louse, with a monse in its mouth : this it laid as an offering at its mistress's feet, and went away.

"For above a year it continued to bring these tributes to her. Even when it had kittens, they were not allowed to touch this reserved share; and if they attempted to eat it, the mother gave them a little tilp- 'That is not for thee.' After a while, however, the mistress accepted the gift, thanked the giver with a pleased look, and restored the mouse, when the cat permitted her children to take the prey which had scrved its purpose in her eyes.

"Here was a refined feeling of gratitude, remembered for months afterward, quite disinterested, and placed above the natmal instincts (always strong in a cat) toward her own offspring."

Urged by a similar feeling, iny own cat, "Pret," used invariably to give his mice to me.

He used to kill the animal in a most chrious mamner, i.e., by taking it, while quite unhurt, by the tip of the tail, carrying it to the top of the house, and dropping it down the well of the staircase. After repeating the process a few times, he would bring the mouse to me, and while I stroked and praised it, would keep rubbing himself against me and purring his content. He then took the monse again, played with it for a while, and then brought it back to me. If the study door were closed, and he conld not gain admittance, he always left the mouse on the mat, previously having bitten off the animal's head. He had a strange fancy, also, for putting the mice into my bed; and once, on leaving $m y$ room in the early morning, I found no less than nine mice laid in a row just ontside the door. Afterward when we mored into the country, and he took to catching rats instead of mice, he acted in precisely the same manner, sometimes bringing me three or four lats in a single day.

Now in both these cases the motive was one that would show credit to humanity. There is nothing that cats like so well as a monse, and yet, just becanse they thonght mice the most precious object in the world, the cats gare their mice to those whom they loved. Affection, self-denial, generosity, and gratitude were thus exemplificd, all being qualities which of necessity belong to the spiritual and not to the animal nature.

Pret was also remarkable for generosity toward his own kind. An examplc of this trait of chalacter is given in my "Glimpses into J'etland," published by Messis. Bell \& Daldy. 'The animal was then living in London:

"When he was a few months old he began to scripe acquaintance with other cats, and used to meet them in a back-yard, which, by common consent both of cats and householders, seemed to be the feline club-house of the neighborhood. Now it was very well of Pret to be social in his habits, but when he took to hospitality the question became serions.

"It is true that he never allowed strange cats, no matter how big they might be, to enter the house; but then he was fond of entertaining his friends in the yard, and was in the habit of bringing his dinner to the club for the benefit of his acquaintances, and then wanting a second dinner on his orm accomnt in the evening. He even went so far as to be disgusted with the meals furnished to a neighboring cat, thinking that cat's meat was not fit for feline consumption. Acting on this supposition, he was seen to take away the cat's meat as soon as it was bronght by the itincrant purveyor, to carry it into the cellar, bury it under a heap of sniall coal, and to take lis own dinner up-stairs for his friend.

"Eren these proceedings might have been pardoned; but Pret's generosity developed so rapidly that we should have becn obliged to devise some efrectual check, had not a removal to another house put an end to the acquaintance.

"Finding that his orn meals were not sufficient to entertain his friends in the liberal manner in which he thought himself bound to act, he took to ransacking the larder, into which chambel he contrived to gain admission in spite of many precautions. In vain did we keep the doors shut and the windows fastened, so as to exclude any animal larger than a mouse, for Pret always managed to enter the forbidden precincts whencver lie chose. At last we found out that he achieved the feat by hiding under the servant's dress, and stealthily creeping in when she had occasion to visit the larder.

"On one occasion I heard an odd solt of a bumping sound on the stairs, as of some one who was dragging up a burden which could with difficulty be lifted. On going to investigate the source of the unwonted sounds, I found that they were caused by Pret, who had made a raid on the lariler. He liad contrived to drag out of the dish, and half-way up-stairs, the entire bone of a leg of mutton, resting on each step in orde: 
to get his breatl, and then hauling the bone np the succeeding step. The ant pulling a stick over rough ground presents an exact resemblance to Pret dragging the heary bone up-stairs."

It must be remembered that this labor was not undertaken for his own selfish purposes. He had not the least idea of eating the meat which he was carrying off, but intended to give it all to his friends.

An anecdote, curiously similar to that which has been related of two cats, has just been sent to me.

There was a cat whose kittens had been rescued from danger by her master, to whom she formed a deroted attachment. During his last illness she never left his room except for the purpose of procuring food, and even then she ate it hastily, and rushed up-stairs again as fast as possible. One day, in order to slow her gratitude and affection, she went and calught a mouse, which she laid on his pillow.

I have always thought that the good qualities of the cat have seldom been appreciated at their just worth. This one trait of generosity, which we all agree in considering as one of the noblest characteristics of man, is dereloped very greatly in the cat, which, instead of being a greedy, selfish animal, as we are generally told, is really a very unselfish and generous one, capable of great self-sacrifice, and for objects which appenr hardly worthy of it.

The following anecdote of generosity in a cat was told to me by Mr. Zwecker, the well-known artist, to whom I am indebted for so many admirable illustrations.

A friend of his had a couple of tame sea-gulls which ranged the garden freely, one wing of each being clipped, to prevent them from flying away. He had also a fine young cat, which struck up an oddly assorted friendship with the gulls. After a while she evidently compassionated their crippled condition, and thought that it prevented them from hunting. So she set to work at hunting for them, and was in the habit of bringing them little birds and mice, which they ate with the solemn satisfaction of a gull at meals. It is astonishing, by the way, what a lirge morsel a gull can swallow. I have often seen a gull take a large slice of bread-and-butter by the middle, and, in spite of the narrowness of its beak, the bird contrived to swallow the slice without putting it down or breaking it.

The following account of generosity on the part of a cat was sent to me by a lady living near
Brighton. I knew both the animals mentioned. "Nelly" was a large, black, silken-haired retriever, and a great favorite.

"In the hot weather our large dog Nelly, whom you admired so much, used to be chained under a large oak in the grounds at the back of the honse, just within sight of her kennel and the yard door. This was done that she might have the comfort of the cool position during the heat of the day, and at the same time command the back entrance to the house. 'This, however, took her away from the neighborhood of the cook, and the little scraps and dainty bits which used to be given to her now and then while the different meals were in course of preparation.

"At the same time, we had a dear, motherly old cat, who did not approve of the change of position in which her friend Nelly was placed. Still less did she approve of the cook putting all the scraps in a plate, instead of giving them to Nelly. So she set herself to work at conveying them to her friend, and every thing that was not too lirge for her to carry or drag along she took to the dog under the tree, and seemed delighted when she saw her friend eat them.

"Now she never stole any thing for herself, but she would always do so for any of the dogs. She used to carry little treats to a small dog that was chained up in the house, but this was after she developed the plan of helping Nelly to the dainties of which she, in her pussy-cat brain, considered her friend to have been defranded."

I know of a somewhat similar case, where a cat was seen to steal a piece of meat and run off with it. She was followed, and then it was found that she had stolen the meat in order to feed a miserable cat that had fallen into a deep hole, and could not get out.

The late Captain IIall, author of the wellknown "Life among the Esquimaux," was a great appreciator of the lower animals, especially of the dog. There was one sledge-dog in particnlar who was a particular favorite with Captain Hall, in consequence of his intellectual character, and the odd, quaint ways which he had. 'The reader will admire the singnlar self-denial and generosity of the animal as shown in the story told by Captain Hall :

"As Koojesse cautiously proceeded, we all watched him most eagerly. Fifteen minutes saw him 'breasted' by a small island, toward which the decr approached. When they were within rifle-shot he fired, but evidently missed, for the game wheeled around and darted away.

"Directly the report was heard, 'Barbekark,' my Greenland dog, bounded off toward the bat- 
tle-ground, followed by all the other dogs. This was ammoying, as it threatened to put an end to any more firing at the game; and, if they would lave heeded ns, we should instantly have recalled them. But it was now useless. 'The dogs were in full chase, and fears were entcrtained that if they got too fill away, some, if not all of them, would be lost. At length we saw Barbekark, pursuing, not in the deer tracks, circuitous, flexuons, mazy in course, but in a direct line, thus evincing a sagacity most renarkable. The other dogrs, not taking the same course, soon fell behind.

"On and on went Barbekark straight for" a spot which brought him close upon the deer. The latter immcdiately changed their course, and so did Barbckark, hot in pursuit after them. Thus it continued for nearly two hours; first this way, then that; now in a circle, then zigzag; now direct, then at right angles, among the numerous islands at the heid of the bay.

"For" a while notling more was thought of the affair, save an expression of regret that the dogs would not be able to find their way home, so far had they been led by the enticing game.

"A little before twelve, mid-day, Barbekark was seen coming back, and presently he came on board, with blood around his mouth and over his body. No importance was attached to this beyond supposing that he had come into collision with the deer; but as for killing one, the thouglit was not entertained for a moment. Those who had often wintered in the Arctic region said they had never known a dog to be of any nse in liunting down deer, and therefore we concluded that our game was gone. But there was something in the conduct of Barbekark that induced a few of the men to think it possible he had been successful. He was fidgety, and restlessly bent upon drawing attention to the quarter where he had been chasing.

"He kept whining, and going first to one and then another, as if asking them to do something he wanted. The captain even noticed him jumping about, and playing unusual prauks, running toward the gangway steps, then back again. This he did sereral times, yet no one gave him more than a passing notice. He went to Keeney, and tried to enlist his attention, which at last he did so far as to make him come down to me.

"I was writing in my cabin at the time, and mention it; but I gave no heed, being so much occupied with my work. Perhaps, had Barbekark found me, I should have comprehended his actions. As it was, he failed to convey his ineaning to any body. Presently one of the men, called 'Spikes,' went off to the wreck of the Rescue, and Barbekark immediately followed; but, seeing that Spikes went no farther, tlie dog bounded off to the northwest, and then Spikes concluded that it was really possible that Barbekark had killed the deer. Accordingly he returned on board, and a party of the ship's crew started to see about it, though the weather was very cold and inclement. 'They.were away two hours; and when they came back, we conld observe that each was carrying something like a heavy bundle onl his head.

"Still we conld not believe it possible that it was portions of the deer' and only when they came so near that the strange fact was perceptible, conld we credit our senses. One man, almost Hercules-like, had the skin wrapped around lim, another had half of the saddle, a third the other half, and the rest each some portion of the deer that we had all especially noticed. In a short time they were on board, and deposited their loads triumphantly on the scuttle-door leading to the cooking department below.

"Every officer and man of the ship, all the Innuits and Innuit dogs, then congregated round the tempting pile of delicious fresh meat, the trophy, as it really proved, of $m y$ fine Greenland dog, Barbekark. The mniversal astonishrnent was so great that hardly a man of us knew what to say. At length we heard the facts, as follows:

"Our men had followed Barbekark's return tracks for about a mile from the vessel, in a direct line northward; thence westward some two miles farther to an island, where, to their surprise, they found Barbekark and the other Greenland dogs seated upon their launches around the deer lying dead before them.

"On examination, its throat was shown to be cut with Barbekark's teeth as effectually as if any white man or Innuit lad done it with a knife. The windpipe and jugular vein had both been severed; more, a piece of each, with a part of the tongue, the skin and flesh covering the same, had actually been bitten ont. The moment Sam, one of the men in adrance of the rest, approached, Barbekark jumped from his watchful position close by the head of lis victim, and lan to meet him, with manifestations of delight, wagging lis tail and swinging his head about. At the same time he looked up into Sam's eyes, as if saying, 'I've done the best I conld; I've killed the deer,eaten just one luscions monthful, and lapped np some of the blood. I now give up what you see, merely asking for myself and these my companions, who have been faitlfully guarding the prize, such portions as yourselves may disdain." " 
It is impossible that human beings could hare acted more generously, and it is tolerably certain that few savages would have done as much. Indeed, after reading the accounts of the African savages as written by Livingstone, Baker, Grant, Burke, Burton, and other modern travelers, we can but come to the conclusion that if a number of sarages in the service of a traveler had killed an animal, very few minutes would have elapsed before the carcass was torn to pieces.

See, also, how many linman attributes are here shown. There is Reason. The animal, on hearing the gum, and seeing the deer go off, thought that his help was wanted, and at once gave it, with the assistance of his comrades, over whom he evidently exercised the authority that is so often evinced when peculiarly intellectual animals are brought in contact with those less highly gifted. The latter at once acquiesce in their own inferiority, and submit to the leadership of their acknow'edged superior. His reasoning powers were again shown by the way in which he led the chase of the deer-not following their circular tracks, but cutting across th $\mathrm{cm}$, just as if he had been a mathematician who knew that the chord was shorter than the arc.

Having killed the deer, he set his companions to watch tle carcass, while he went off to bring assistance in carrying the deer home. He knew that although he and his companions could not get the deer to the ship, the men could do so, and accordingly he went to ask their aid in his own doggish language. He must also, before he started, have told his companions that they must not eat the deer. The generosity displayed by all the a $\operatorname{logs}$ is really wonderful, when we come to consider the circumstances. An Esquiman sledgedog is always humgry; for, in the first place, the constant and serere work in which they are engaged is enongh to gire them a ravenous appetite; and in the next, the supply of food is always very limited.

So furiously hungry are these dogs that it is no uncommon thing for them to eat up the leather harness of the sledges, and at night it is necessary' to suspend all such articles out of their reach. Yet, with the carcass of a newly killed reindeer before them, and with the certainty before their eyes of such a meal as they had never enjoved, and were never likely even to see again, these dogs were generous enough to restrain their appetites, and, instead of gratifying their raging hunger on the dainty banquet within their reach, sat and guarded it for hours, and delivered it mntouched to their masters. How many hungry men are there who wonld have acted so generons a part, and have exercised such trying self-denial? We shall hear more of Barbekark in another portion of this work.

In the Naturalist's Magazine there is a remarkable instance of generosity on the part of a sparrow. As a general rnle, sparrows are remarkable for their ability in taking care of themselves, and for the manner in which they will seize for themselves the property of others. For example, there are many places where the housemartin nised to abound, and is now almost extinct, simply because the sparrows allowed them to build their mud nests, then ejected them, and took possession themselves. Sparrows have also been known to act as the eagle does to the osprey, and the skina-gull to the smaller species, i. e., allow the weaker bird to take all the trouble of capturing prey, and then take it away by violence.

There are, however, exceptions to every rule, and a very honorable one is recorded in the $\mathrm{Nat}$ uralist's Magazine. A lady possessed, among other birds, a canary, whose cage used to hang outside the window. One morning a sparrow perchedi on the cage, and seemed to hold a sort of conversation with the inmate. Presently he flew away, but shortly returned with a grub, which he dropped into the cage. Every day at the same time the sparrow made his appearance with his accustomed offering, and the canary at last became sufficiently familiar to take his food directly from the sparrow's beak. The lady then put some more cages out of the window, and the sparrow fed all of the inmates, invariably, however, selecting the canary for his first visit, and making the longest stay with that bird.

Now let us pass to generosity in the sense of Magnanimity, or unwillingness to resent an injury, though possessing the power to do so. 'There are few qualities in human nature more noble thin the capability of foregoing ravenge when the offender is powerless to resist. I suppose that all my readers have heard of the famous answer to a justly offended man, "Would it not be manly to resent such an affiont?" "Yes, but it would be godlike to forgive it." Those who are conscious of power are never afiaid to forgive; and thus it is that in the daily services of our Church the very first invocation runs thus, "Almighty and most mercifnl Father." Almighty, and therefore all-merciful. Looking back through history, we shall find that those whose names have lived as the noblest of the luman race have been distinguished by that divine quality of mercy which Shakespeare has described in words too familiar for quotation.

Indeed, when we find those beings whom we 
call "brute" beasts rising to a moral grandeur" which few men can attatin, disdaining to arail themselves of the opportunity of rengeance, and even repaying evil with good, it does seem an utter absurdity to say that they are not acting under the inspiration of Him who gave us the celestial maxim, "Love your enemies." By their action they show themselves worthy of life everlasting; and what they deserve they will assuredly receive at the hands of Him who is Justice and Truth.

Consciously or unconscionsly, this feeling is acknowledged among mankind. Taking our own nature, for example, prize-fighters are not considered among the most elevated class of society. Yet one of the fundamental rules of the "ring" is, "Don't hit a man when he is down;" and any boxer who demeaned himself by such an act would be at once adjudged to have lost the fight, and would be disqualified from entering the ring for the rest of his life. Striking below the belt is another disqualifying action; and the custom of shaking hands before a fight, and the victor sending round his hat on behalf of his vanquished foe, are customs showing that even in this low stratum of society there is a recognition of the one great principle.

Of the axiom that those who are strongest are least apt to use their strength, a curious example occurred some years ago, when the "ring" was in its palmiest days, and the highest in the land went openly to see a fight as they now go to a horse-race.

A man in the quarrelsome stage of drink came into a public-house, and began to wrangle with those who were already there. At last he took umbrage at one of the guests who was sitting quictly smoking his pipe, and finding that he was not to be drawn into a fight, called him a coward and struck him on the face, drawing blood. 'The man merely wiped his face, and went on with his pipe. One of the guests exclaimed, "How can yon stand this, 'l'om Cribb?" At the sound of the dreaded name, the assailant dashed out of the room, and was not seen again. Cribb could afford to take an insult from a man whom every one present knew he conld have killed at a single blow.

As with man, so it is with the lower mimals; and there are many instances on record wheie the strong have distained to make reprisals on the weak, no matter what the offense might be.

I knew two dogs in whom the "quality of mercy" was strongly developed. One was an enorinous animal called "Lupo," becinse le looked jnst like a white wolf, except that he was very innch larger. Handsome as he was, his enormous size made lim very inconvenient in the house, for when he chose to lie on the heartl - rug no one had a chance of coming near the fire. In the sane house was a little black-and-tan terrier called "Tiny." Now in cold weather 'Tiny liked to have a warm couch by the fire; and whenever Lupo had composed himself to sleep, she used to climb upon his body, turn round and round in his long fur as if he were nothing but a door-mat, and also settle down to rest.

The absurdity of the proceeding was crowned by the fict that when she had thus settled herself she would not allow Lino to move. If he even ventured to stir and disturb her, she would fly savagely at his head, barking and growling viciously; and if he did not at once lie quiet, thought nothing of biting one of his long ears, Lupo submitting as tamely as if he had taken his name from a lamb, rather than a wolf.

Yet Lupo was by no means an animal to be trifled with. He once had a tremendous fight with his master about a bone; and it was not until after he had bitten his antagonist sererely in the wrist and arms, and had had a succession of sticks broken over him, that he succumbed. Haring done so, he, after the manner of well-bred dogs, gave in completely, and came crawling to his master's feet for forgireness.

As to dogs in general, Lupo had an objection to them, and, when he accompanied his master's carriage, had generally to be muzzled, lest he should pick up any stray dog, give it a shake, toss the dead body over his shoulder, and trot on as if nothing had happened. The curious point in his temperament was, that if a dog ran away from him that animal was doomed, unless Lupo had a muzzle. But if the dog flew at him he respected that dog, and treated him with perfect forbearance. I lave seen as many as three dogs at a time hanging on to him, Lupo trotting on unconcernedly, and not taking the least notice of them, even when they dropped off through weariness of jaw.

There was one dog which had actually fought himself into friendship with Lupo. He was a terrier belonging to a blacksmith who lived about half-way between the station and the house of Lupo's master. For some time the animal used to fly at Lnpo twice daily, namely, during the progress to and from the station; Lupo, as usulal, respecting him for his courage, but not even attempting to injure hum. At last having, like Mrs. Malaprop, begun with a little aversion, the two animals struck up a friendship, the terrier watching for Lupo, gamboling with him until he had reached his journey's end, and then returning home alone. 
My bull-dog "Apollo" was equally magnanimous: he would suffer almost any provocation from a dog smaller or not much larger than hinnself, but never would allow any liberty to bc taken by a big dog. Over and over again has he allowed little dogs to bite him without troubling himself to retaliate; but if a big dog rentured upon an insult, that dog had to rmin.

Onc day as I was walking to the post-office, with Apollo at my heels, as usual, a remarkably fine black retriever came up and began to growl at him. Apollo only gave him a glance out of the corner of his eye, and trotted on. The rctriever came close, and continued to growl; whereupon I cautioned his owner that, if his dog would let Apollo alone, Apollo would have nothing to say to him, but that if the retriever continued his insults I could not answer for the consequences.

The only reply was a disdainful smile, and a contemptuous look at the dog. After some more annoyance Apollo gave a slight growl, and the hairs of his back began to bristle ominously. Again I gave warning, but with the same result. Presently the retriever flew at Apollo, bit him in the ear, and next moment was on his back, with Apollo's grip on his throat. The retriever's master was so startled at the sudden change of affairs that he could not interfere, and in a minute there would have been a dead retriever. Fortunately I had taught Apollo to loosen his hold at the word of command (the hardest lesson I ever liad to teach a $\operatorname{dog}$ ), and I ciilled liim off.
In a few moments the fallen animal recovered his breath and his legs, and made off at full speed, yelping with pain and terror, and I saw nothing more of him. As for Apollo, he fell back unconcernedly to his place at my heels, and trotted on as if such a thing as a retriever lad never becn in existence.

The anecdotes which have been just related show that animals can act magnanimously toward each other. Here, however, is an instance where a dog which would most assuredly have assaulted the man whom he hated, had the latter been in a position to defend himself, did most nobly forego his vengeance when the enemy was completely at his mercy. As is usually the case with the most characteristic dog anecdotes, the event occurred in Scotland:

"The manager of a mill in Fifeshire was very much disliked by the watch-dog, probably because he had acted harshly to the animal. One very dark night he strayed from the path and fell over the dog. Perceiving the mistake which he had made, and that he could not recorer himself, he gave himself up as lost, the dog being a very powerful one. The animal, however, was magnanimous enough to spare a helpless enemy, and to lay aside old grievances. Instead of seizing the prostrate man by the throat, the dog only licked his face and indicated his sympathy. Ever afterward the man and the dog were great friends." 


\section{CHAPTER IX.}

\section{CHEATERY.}

Alimal Swindlers._"Barbekark" as a Cheat._Roguery Detected.-Dogs Shamming Lameness.-Dogs Cheating Each Other._The Elephant, "Burra Sahib," Hiding a Cake.-Comparison with IIumanity.Golden-crested Wren as a Cheat and Thief.-Two Ravells Uniting to Cheat a Dog out of his Dinner.Alliance between a Dog and a Raven.-Principle of the Ambuscade.

All virtues have their opposite vices; and just as there are animals capable of exercising great self-denial in order to give to others that which belongs to themselves, and even displaying an amount of generosity unsurpassable by any human being, so there are animals which can cheat like accomplished swindlers. Sometimes, as in the following instance, the same animal is capable of both acts.

Here is an anecdote of "Barbekark," the dog which killed the deer, and then gare it up to his master. 'The narrator is Captain Hall:

"I have before mentioner some particulars of these dogs, and I now relate an anecdote concerning them during our passage across from Greenland.

"One day, in feeding the dogs, I called the whole of them around me, and gave to each in turn a capelin, or small dried fish. 'To do this fairly, I used to make all the dogs encircle me, until erery one had received ten of the capelins apiece.

"Now Barbekark, a very young and shrewd dog, took it into his head that he would play a white man's trick. So every time that he received his fish he would back square ont, move a distance of two or three dogs, and force himself in line again, thus receiring donble the share of every other dog. But this joke of Barbekark's bespoke too much of the game that many men play upon their fellow-beings, and, as I noticed it, I determined to check his doggish propensities. Still, the cunning and the singular way in which he evidently watched me induced a moment's pause in my intentions.

"Each dog thankfully took his capelin as his turn came round; but Barbekark, finding his share come twice as often as lis companions, appeared to shake his tail twice as thankfully as the others. A twinkle in his eyes, as they caught mine, seemed to say, 'Keep dark; these igno- rant fellows don't know the game I am playing. I am confoundedly hungry.'

"Seeinc my face smiling at his trick, he now commenced making another change, thus getting three portions to each of the others' one. 'This was enough, and it was now time for me to reverse the order of Barbekark's game by playing a trick upon him. Accordingly every time I came to him he got no fish; and although he changed his position three times, yet he got nothing. Then, if ever there were a picture of disappointed plans, of enry at others' fortune, and sorrow at a sad misfortune, it was to be found on that dog's countenance as lie watched his companions receiving their allowance. Finding he could not succeed by any change of his position, he withdrew from the circle to where I was, and came to me, crowding his way between my legs, and looked up in my face as if to say, 'I have been a very bad dog; forgive me, and Barbekark will cheat his brother $\operatorname{dogs}$ no more. Please, sir, give me my share of capelins.' I went the rounds three times more, and let him lave the fish, as he had shown limself so sagacious, and so much like a repentant prodigal dog."

As chentery requires the use of the intellect, it is evident that the most intellectual animals will be the most accomplished cheats. Dogs, therefore, may be expected to be considerable adepts in chenting, and are often very amusing in their attempts to deceire human beings. Here are one or two more examples of cheating in the $\log$ :

One of my friends had a couple of little toy terrier dogs. As is usually the case in such instances, though very fond of each other, they were horribly jealous with regard to their master, and neither could endure to see the other caressed. It so happened that one of them broke its leg, and was in consequence much petted. Its companion, seeing the attention that was paid to the injured animal, pretended to be lame itself, 
and came limping to its master, holding up the corresponding leg, and trying to look as if it were in great pain.

The following anecdote is sent me by a friend:

"A Skye terrier of our" acquaintance nimed 'Monte' had at one time a very sore leg, and during his illness he got a great deal of sympathy and petting. Ever since, when he has been in any mischief, he comes running on three legs, holding up the one which was once sore, but is now quite well. In his own way he is quite as arrant an impostor as the well-known begging 'sailor' with one leg tied up to look as if he had lost it."

A curions and rather ludicrous instance of cheatery on the part of the dog was observed by one of my friends.

He has three little black-and-tan terriers, father, mother, and daughter, which are great pets, and consider the honse as their own property. Like most pet dogs, they have their favorite spots by way of conches; and as they all three generally take a fincy to the same spot, there is occasionally a difference of opinion and a slight loss of temper. The one pet spot of all is a soft cushion at the head of a sofa. Now the cushion had accommodated easily the fither and the mother; but when the diunghter came, and in course of time wanted her share of the couch, it was found that the quarters were rather too linited for comfort, especially as the daughter persisted in growing until she reached the size of her parents.

One day the futher and daughter had got into the room first, and according to custom made straightway for the cushion, on which they established themselves comfortably, occupying the whole of its surface. Presently the mother came in, and also went to the cushion. She tried to take her place on it, but her hnsband was too selfish and her daughter too undutiful to move, and in consequence she had to retire.

Presently she went to the farthest corner of the room, and suddenly began to scratch violently, barking, growling, and sniffing as if she were digging out a rat. Up jumped the others, all blazing with excitement, and anxious to have their share of the sport. As soon as they had got their noses well down in the corner, the mother ran to the sofa at full speed, jumped on the cushion, curled herself romd, and was happy. However, she was generous in victory, and made room for her husband and danghter as they came back to the sofa crest-fallen and humiliated.

One of my brothers has furnished me with an account of an andacious piece of cheatery practiced by his dog:

"My dog is a white terrier, called 'Sambo,' on account of his color, supposed to be a purre specimen of the 'fox' variety, but perversely exlibiting unmistakable evidences of the existence of the more plebeian 'bull' somewhere in the roll of his ancestry. He is good-tempered and affectionate, and devoted to his master-and to sport, especially to the pursuit of rabbits.

"One fire morning last Jannary I took him out for a couple of hour's' rabbiting, to his great joy, brit, as I could also see, by his way of constantly coming back to have a look at my face, to his intense puzzlement. An afternoon alone with me was quite natural, and according to custom; but starting at eleven A.M. had always meant a day with the keejers, and where were the keepers? We found no rabbits; but then he was not busy as usual: his head was not sufficiently clear from other matter's to look them up with his usual care and persererance.

"He passed many a likely bush without even a glance of his eye, and I began to fear that he was ill; when suddenly, as lnck would have it, we heard several shots in rapid succession, and found onrselves in the midst of a regular rabbiting party. The effect upon Sambo was miracnlous; his tail and ears went up, and he sprang at once from a state of low despondency into one of violent activity. $A$ few moments before and he seemed to have made up his mind that the British rabbit was an extinct animal, and his master a great fool for carrying a gun in pursuit of it: of course, as he was under orders, he must look for them, or pretend to do so-but it was awful humbug. Now, to see him rushing all over the place, quartering the ground, with his tail going, and his nose investigating every little tuft, one woukd have thought there was a rabbit for every square yard.

"Things went on as usual until the time arrived that I had to take nny leave and return home. Now not only had we just arrived at a favorable spot in the covert-a fact just as well known to the dogs as to ourselves-but there were unmistakable signs of approaching luncheon. My first call to my dog was, therefore, unheeded: he had suddenly conceived a violent affection for another dog, with whom, by the way, he could never on ordinary occasions agree, and in the interchange of friendly confidences was quite abstracted from the outer world.

"A more imperative summons made him start - a very false move; but he at once compensated for it by facing round sharply in the opposite direction to me, and looking anxiously up 
the drive instead of down, with his head and ears np, ats if he rather expected to see me at the end of it, about lialf a mile off. Howerer, it would not do, and he wis reduced to following me, though he kept to heel with drooping head and tail, and many a wistful look behind.

"We had hardly got well out of the sight of the keepers when he suddenly brightened up, as though lie thought life liad ret some joys in store for lim, trotted on in front, and behared himself as usual. Suddenly, just a few yards from the exit from the covert, he 'inade a point' at a solitary tuft of grass and rushes. I was astonished that a rabbit could be harbored there, as we had but just passed orer the very spot with a regular altray of dogs and beaters; but Sambo said 'rabbit' as plainly as possible: so in went my cartridges again, and the necessary permission was given.

"To my astonishment, no rabbit appeared; but none the less Mr. Sambo went through all the regulation manœurres formulated and provided in such cases. He dashed into the tuft, came out the other side as if in full chase, yelped as if he were only just out of biting distance of his prey, and was lost to sight in a moment; and what is more, he returned not. I whistled and called, but no sound could be heard. Suddenly lis 'little game' flashed upon me. I went back to the keepers, and there was my friend taking his luncheon affilbly with one of then-a particular friend. With the utmost respect for his mental resources, I yet thonght it necessary to be 'firm' with him, and I do not think he will ever play me that trick again."

One of the most amusing mecdotes of attempted cheatery is narrated of an elephant by Lady Barker :

"When we paid them a visit upon the afternoon of the storm, the huge beasts were taking a bath, or rather giving it to themselves by filling their trunks with water and dashing it over their heads, trimpeting and enjoying themselves inmensely. At a little distance the cooks were busy baking the chupatties-al muffin as large as a soup-plate, and nearly as thick-in mud orens; and the grass-cutter's hatd been down to a 'jhed,' or pond, near, to wash the dust off' the large bunales of grass for the elephants' suppers. We talked a little to the mahouts, and one verr picturesque old man seemed exceclingly proud of lis elephant's superior' slyness and cunning, and beggecl us to stay and see him 'cheat.' So we waited till 'Burra Sahib,' or 'Mrr. Large,' had finished his bath and came slowly up to the mahout for his supper.
"The mahout called out to the cook to bring the elupsatties, and made us retire behind a tree and watch what Burra Sahib did. As soon as the cook went away, the elephant put up his trunk and broke off' a large bough of the tree abore him. This they generally do to serve as a brush to keep off flies, so lie knew that was nothing remarkable. He then looker slyly around him with his bright, little, cunning eyes; and as he could not see his mahout, he thought the coast was clear, and hastily snatched up a chupattie, which lie put under the branch on the top of his head. I noticed how carefully he felt with his flexible trunk if any edge was uncorered, and arranged the leaves so as to hide his spoil completely.

"Burra Sahil then raised his roice and bellowed for his supper in loud and discordant tones. The mahout then ran up as if he had been a long distance off, stood in front of him, and commenced handing him the chupatties, counting, as he did so, one, two, three, and so on. The elephant received each in his trunk, and put it gently into his huge mouth, bolting it as though it had been a small pill. 'Twelve chupatties was the allowance, and he required this sort of food to keep him in good condition. When the mahout came to number eleren muffin he looked about for the twelfth in great dismay, pretending that he could not think what had become of it, and calling for the cook to scold him, searching on the ground, and wondering, in good Hindostanee, where that other clupattie could be. The elephant joined in the search, turning orev an empty box which was near, and trumpeting loudly.

"The mahout was delighted to see how much this farce amused me, and at last he turned suddenly to the elephant, who was still hunting eagerly for the missing ehupattie, and reriled lim as a thicf and a 'big owl,' adding all sorts of epithets, and desiring him to kneel down, which Burra Salib did very reluctantly. The mahout then scrambled up on his head, snatched off the branch, and flung down the chupattie, belaboring the elephant well with the bough which had serred to conceal it. It scems that the trick had been played successfully many times before Burra Salib was found out, and the poor cook used to get into trouble, and be accused of keeping the missing chupattie for his own private consumption."

$A$ servant belonging to one of my friends neted just like this elephant. She had broken a valuable China vase, and in order to hide the eridences of her delinquency she broke up the fingments very small and buried them. When the 
vase was missed, she protested that she knew nothing about it. She knew that such a rase was somewhere in the house, but had not the least idea where it could be; and for three whole days slie went over the louse with her mistress, hunting in every cupboard and on every shelf for the article which she had herself buried in the garden.

Birds ean be capable of cheating, not only each other, but other animals. Even the pretty little golden-crested wren has been detected in deliberate theft and deception.

A gentleman was watching a ehaffinch building its beautiful nest, and soon found that he was not the only spectator. At a distance was perched a goldcn-crested wren, which watched the proceedings carefully. As soon as the chaffinch went off to fetch more materials, the gold-crest cunningly stole round in an opposite direction, and carried off' the newly brought hairs, etc., for its own nest. This went on for some time, until at last the aggrieved chaffinch found out the robbery, and chased the gold-crest so fiercely that it did not attempt to renew the theft.

This story is told by Mr. W. Thompson, in his "Natural History of Ireland." He also states that this kind of robbery is not at all uncommon with the gold-crest. Its nest is made of the same material as that of the chaffinch, and so it is accustomed to avail itself of the labors of that bird in order to lighten its own toil.

The celebrated arctic royager, the late Sir L. M'Clintock, mentions a curious instance of stealing on the part of the raven. When they were in Mercer Bay, a pair of ravens, probably male and female, used to hang about the ship, and pick up any refuse food that might be lying abont. At a certain houl of the day the men were accustomed to wash out their mess-tins, the rejected contents of which were regarded by the ship's dog as his proper perquisites. The ravens, however, held a different opinion, and by force of superior intellect almost always contrived to gain their own ends.

As soon as the tins were emptied, and the dog ready for his meal, the ravens set to work to clieat him out of his food. They assaulted him from the front, kecping him from his food by perpetual annoyance, and at last induced lim to make a charge at them. Of eourse, after the manner of ravens, they eontrived to flap their way just out of his reach. This process was repeated until they had inveigled him to a considerable distance, when they took to wing, and being able to fly faster than the dog could run, managed to secure a good meal before he eould reach them.

It is evident that they must have concerted this plan of action between them; so that we see in this ruse an example of reason and the communication of ideas by means of language. My readers may perhaps remember the story of the two dogs who used to hunt the hare in concert, the one starting the hare and driving it toward the spot where the accomplice lay hidden. I knew of an instance where a somewhat similar arrangement was made; only in this ease the two contracting parties, instead of being two dogs, were a dog and a raven, the latter making use of its wings in driving the prey out of the heather into the open ground.

Many instances of such alliances are known, and in all of them there is the curious fact that two animals can arrange a mode of cheating a third. In fact they employ one of the principal stratagens in the art of war, $i . e$. , the ambuscade, or inducing the enemy to believe that danger is imminent in one direction, whereas it really lies in the opposite and unsuspected direction. No one would say that a general who contrived to draw the enemy into an ambuscade acted by instinct: the act would be accepted as a proof of reasoning powers surpassing those of his adversary. And if this be the case with the man, why not with the dog, when the deception is earried out by precisely the same train of reasoning? 


\title{
CHAPTER X.
}

\author{
HUMOR.
}

Practical Joking the Lowest Kind of Humor.-Torture the Iumor of the Savage.-Spinuing Cockchafers. -Making a Boy "Jump like a Dog."-Humor in Birds.-The "Chukor" Partridge and the "Punkahwallah."-Humor in the Buzzard.-The Kestrel's Idea of Humor.-The Humorous Heron._- Making Believe" in Children and Auimals. -Swallows Mobbing a Kestrel._The Same Birds Mobbing a Hare.Swallows Mobbing a Cat.-Spar-Ousels Mobbing a Cat.-Jackdaws Doing the Same.-Ring-Doves Mobbing a Dog.-MIonkeys and Crocodiles.-A Cock Tantalizing the Hens with Food, and Eating it Ilimself. -Sense of Humor in the Parrot.-A Cat Deceived by a Parrot.-The Peacock and the Ponltry.-Humor in the Emeu.-Hnmor in the Mooruk.-A Dog and his Practical Jokes.-A Horse Playing Practical Jokes on a Boy.-Mr. G.'s Pony.-IIorses Chasing a Pig.-Animals Joining in Children's Sports.-A Dog Playing it "Touch."-A Pony and a Cat Playing "Hide-and-Seek" with the Children._-"Peter," the FieldMouse, Playing the Same Game.-A Mischievous Canary.-The Bullinch and the Work-box,-Practical Jokes Played by "Ungka," the Siamese Ape.-Sense of Humor in the Next World.

Among other traits of character which are common to man and beast is the sense of huinor.

This is dereloped in various ways. Mostly it assumes the form of teasing or annoying others, and deriving amusement from their discomfort. 'This is the lowest form of humor, and is popularly known among ourselves as practical joking. Sometimes, both with man and beast, it takes the form of bodily torture, the striggles of the victim being highly amusing to the torturer. Civilized man has now learned to consider the infliction of pain upon another as any thing but an anusement, and would sooner suffer the agony than inflict it upon a fellow-creature. But to the savage there is no entertainment so fasciuating as the infliction of bodily pain upon a human being.

Take, for example, the North American Indian tribes, among whom the torture is a solemn nsage of war, which every warrior expects for himself if captured, and is certain to inflict upon any prisonel whom he may happen to take. The ingenuity with which the savage wrings every nerve of the human frame, and kills his victim by sheer pain, is absolutely fiendish; and yet the whole tribe assemble around the stake, and gloat upon the agonies which are being endured by a fellow-creature. Similarly the African savage tortures either man or woman who is accused of witchcraft, employing means which are too horrible to be mentioned.

Yet eren in these cases the crnelty seems to be in a great degree owing to obtuseness of perception; and the sarage who ties his prisoner to a stake, and perforates all the sensitive parts of his body with burning pine-splinters, acts very much like a child who amuses itself by catching flies, pulling off their wings and legs, and watching their unavailing efforts to escape. I do not know whether it is the case now or not, but some twenty years ago I saw cockchafers publicly sold in Paris for children to tortmre to death; the amusement being to run a hooked pin through its tail, tie a thread to it, and see the poor insect spin in the air. After it was too enfeebled to spread its wings, it was slowly dismembered, the child being greatly amused at its endearor's to crawl, as leg after leg was pulled off. I rescned many of these wretched insects from the thoughtlessly cruel children, and released them from their sufferings by instantaneous death.

In Italy a similar custom prevails, though in a more cruel form, the creatures which are tortured by way of sport being more caprable of suffering pain than are insects. Birds are employed for the ammsement of clildren, just as are the cockchafers in France. A string is tied to the leg, and the unfortunate bird, after its powers of flight are exhausted, is generally plucked alive and dismembered.

It is not done from any idea of cruelty, but from sheer incapacity to understand that a bird or a beast can be a fellow-creature. The Italians are notorious for their cruel treatment of animals; and if remonstrance be made, they are quite astonished, and reply, "Non è Cristiano" (It is not a Christian).

Not that we in England have very much 
to boast of on this score. The Puritans did a good work when they abolished bear-baiting, even though, as Macaulay says, they did so not becanse it gave pain to the bear, bnt because it gare pleasure to the spectators. But ip to the present day there is a latent hankering after similar scenes, even though they are now contrary to law ; and dog-figliting, cock-fighting, badgerdrawing, and rat-killing are still practiced in secret, though they can not be carried on in public.

Mr. IV. Reade, in his work on "Sarage Africa," mentions a case in which a woman and her son, a young boy, were put to death on a suspicion of witchcraft. IThe roman was drowned, and the boy burned alive; sundry packets of gmupowder being tied to his legs, which made him " jump like a $\log$ "- - thus causing great amusement to his torturers. MIr. Reade remonstrated with them upon their cruelty, but they could not be made to see that there was any more cruelty in the fate of the son than in that of the mother. 'The narlator was astounded at the rely notion. "Burning more bad! No, Mr. Reade, burning and drowning all the same." The cruelty was not intentional-it was simply want of understanding. 'To see the boy "jump like a dog" was highly amusing to the spectators, and they nerer tronbled themselves about the fact that the ludicrous contortions were caused by terrible pain. Savages are in many points nothing but children, and they act after childish manners, but with the power's of men for evil.

For example, the poor little boy of seven years of age who was afterward so cruelly burned alive was subjected at the hands of his captors to a species of humor which was vastly entertaining to them. "On the ground cronched the child, the marks of a serere wound risible on his arm, and his wrists bound together by a piece of withy. I shall nerel forget that child's fice. It wore that expression of passive endurance which is one of the traditional characteristics of the savage. While I was there, one of the men held an axe below his eyes: it was the brute's idea of humor."

In a similar manner, the sense of lumor is mostly dereloped in the lower animals by causing pain or annoyance to some other creature, and the animal acts in precisely the sane manner as a sirvage or a child.

Tre will just take a few cases of humor as exhibited by birds.

As might be expected from the character of the birds, sparrows will gratify their feelings of dislike by uniting together for the purpose of mobbing some creature to which they hare an objection. There is a short account in Hardwicke's Science Gossiy for Decculuer, 1872, of a 11 mber of sparrows mobbing a cat.

'The cat evidently intended to make a meal on one of the birds, but was greatly mistaken; for the sparrows dashed at him so fiercely that he soon turned tail and ran into the house, one of the sparrows actually pursuing lim into the house. Poor 'Tommy raul up-stairs, and was found crouching in terror under one of the beds. 'I'his happened in London, where, by the way', sparrows are much less numerons than they used to be: this, I beliere, is chiefly if not entirely dne to the staff of street-cleaning boys, who remove the substances from which the sparrows used to derive the greater part of their subsistence.

An account of a somewhat similar adrenture is given in the Dumfries and Galloway Standard.

In the year 1856 a number of "rooks" were in the habit of assembling on a house, and it was thought that they had nests there. One day a cat came prowling orer the roof, to the great discomfiture of the rooks, who assembled oll the roof of a neighboring house and held a consultation. This being over, they proceeded systematically to attack the foe, dashing at her in groups of three $\mathrm{Ol}^{\circ}$ four, flapping their wings in her very face, and screaming dismally.

As for the cat, though a young one, she was not in the least dismayed, her courage rising to the occasion.

"It then," writes a spectator of the scene, "looked the rery image of clefiance; and a more graceful figure of a cat we never saw when, in fighting attitude, it strained its head and struck out its dexter paw. 'The cat frequently changed its position, with the riew, we suppose, of doing its best to bring itself into closer quarters with the crows; but in vain. They kept up a slower of abusive language, and occasionally almost grazed the lead of Grimalkin with their feathers, but they never rentured going within her reach. Puss mewed impatiently at times, as much as to say, 'Oh that I lad wings for' a few minutes, and then I would put an end to your noise and bluster.'

"This skimish between this valolons cat and the crows lasted finlly half an homr, and ended in a sort of drawn battle. 'The cat would have kept the castle long enough, in despite of them; but it could neither get hold of them nor their nests, so it at length quietly descended."

In his "Natiral Iistory of Ireland," Mi. "Thompson records a case where that rather rare bird, the ring-ousel, mobbed and drove away a dog. 
Mr. Thompson was shooting in the Crow Glen, accompanied by his pointer, which was some yards in adrance. Suddenly the dog was attacked by two male ring-ousels, which dashed at its head, accompanying each stroke with lond shrieks. They were incited to this action by a female, which, after setting them at the dog, retired to a distance and looked on at the fight. The dog was so alarmed by the attack of the birds that he was obliged to retreat to his master. The birds were so determined in their onset that they even attacked $\mathrm{Mr}$. Thompson and two of his friends, who were accompanying him.

Had these birds been male and female, it might have been thought that they were defending their young, or trying to decoy the dog from their nest; but they were both males, and in their adult plumage. 'The action lasted for more than a quarter of an hollr.

All those who have watched the habits of animals must have remarked how widely spread among them is this species of humor-namely, annoying and insulting a stronger being than themselves whenever they think that they can do so with impunity. And so strong is the impulse to gratify their sense of humor that they do not hesitate to do so at the risk of their lives. M. Mouhot, in his work on "Indo-China and Cambodia," mentions that he has often witnessed very amusing scenes between the monkey and the crocodile.

The latter animal is lying half asleep on the bank, and is espied by the monkeys. They seem to consult together, approach, draw back, and at last proceed to overt acts of annoyance. If a monkey can find a convenient branch, he goes along it, swings himself down, hangs by a hand or a foot, slaps the crocodile on the nose, and instantly scrambles up the branch ont of the reptile's reach. Sometimes, when no branch is sufficiently near, several monkeys will hang to each other so as to make a chain, and, swinging backward and forward over the crocodile's head, the lowermost monkey will torment the reptile to his heart's content. The cream of the joke is when the crocodile is at last so irritated that it opens its enormous jaws, makes a vicious snap at the monkey, and just misses him. Whenever this happy event occurs, there are screams and chatterings of exultation from the monkeys, and a vast number of joyful gambols executed among the branches.

Of course, according to the old proverb, the pitcher may go too often to the well; and it does occasionally happen that the monkey does not escape in time, and is ingulfed in the crocodile's jaws. Whereupon the cries of exultation are changed into groans and shrieks of terror, and the whole assembly make off as fast as they can. But experience does not teach them cliscretion, and in two or three days they will be at the same game again.

In Mr: T. C. Jerdon's "Birds of India" there is an amusing notice of the habits of the Chukor" partridge (Caccalis Chukor) when domesticated. It is very tame and familiar, and sometimes becomes rather a nuisance on account of its habit of playing tricks on people. It has a special facility in discovering the most vulnerable spot, and inflicts sly pecks at the bare feet of the native servants as they move through the house. Its great amusement, however, is to find the man who pulls the punkah half asleep, as is customary with these men as they rock backward and forward at their monotonous task. The little bird pecks his legs so fiercely and actively that he is quite unable to drive it away and go on with his work, and he is at last obliged to call for some one to rid him of his tormentor.

A somewhat similar custom is related by $\mathrm{Mr}$. Thompson, in his "Natural History of Ireland," the bird in this case being a tame buzzard. It had a way of flying after strangers, and knocking their hats over their eyes with a blow of its wing; and it was so quick about it that, even when forewarned, its victim had some difficulty in erading the blow. The same bird took an objection to the bow of its master's shoe-ties, and used to fly at his feet and suddenly untie the strings.

I am personally acquainted with a heron in which this form of humor is largely developed.

The bird was in one sense tame, for it was allowed to run loose in a garden, and was on the most affectionate terms of friendship with one of the men employed in its owner's warehouse. It is really beautiful to see the welcome which the bird gives to the man, and to hear her low, loving gabble as she rubs her head against him, or takes his hand gently in her beak. He has taught her several tricks, as, for example, to take off his hat at the word of command. She is a beautiful creature; and if the sense of humor were not quite so strong, she would be an admirable bird. Unfortunately, she has an unappeasable relish for practical jokes, especially against human beings, looking quite soft and gentle until they are within reach, and then driving her long, sharp bealk at them with the rapidity of a serpent's stroke.

On one occasion her sense of humor was de- 
reloped to sueh an extent as to cost the loss of lier liberty.

'The garden in which she lives is also inhabited by a great number of aquatic birds, principally gnlls and ducks, and they have a way of laying their eggs in different parts of the garden. One day a learned and respected neighbor went into the garden, and, secing some ducks' eggs on the ground, stooped down to examine them. As he was thus engaged, the heron stole up softly behind him, and delivered so tremendous a blow that she fairly knocked him on his face.

The unfortmnate gentleman, knowing that the heron has an unpleasant way of pecking at eyes, erouched as closely to the ground as he could, sheltering his eyes with his arms, and calling for help as loully as he could in such a position. The heron, enjoying the joke immensely, mounted on his back, and triumphantly maintained her post there until assistance arrired, and she was driven off".

Since that exploit she has not been allowed to run loose, but has been confined in a roomy cage, in which she can run about. Even under these circunstances she delights in enticing people to come near the enge, and then darting her beak at them between the bars-a joke which she has several times played at my expense. The distance to which she can project her beak is quite marvelous, and it is no difficult matter for the bird to decoy too eonfiding persons within her reach.

IInmor, indeed, seems to be a special charaeteristic of the hawk tribe. I knew a tame sparrow - hawk which was always trying to circunvent a magpte belonging to the same house; and the extraordinary ingenuity which these birds showed in playing practical jokes on each other could not have been surpassed by human beings. In Hardwicke's Science Gossip of March, 1871, there is an account of a tame kestrel which showed a similar sense of humor :

"Insects of all sizes and kinds were summarily devomred, and I have more than once captured wingless females and imperfectly formed moths unable to fly, by finding her dancing round them in their endearors to escape, and with a gentle nibble giving them a hint to run fastcr. When the poor insects were too maimed or exhansted to crawl farther, the sport being ended, they were eaten without further delay. Indeed, she appears quite indignant with spidcrs, because, instead of hurrying off, they lie down and curl themselves up."

Here we hare an instance of a bird dealing with an inseet just as the French children dealt with the cockchafers, neither bird nor children having the least ilea that the struggles which amused them so much were the result of pain.

The same bird, if she could find neither mouse nor insect, would pounce on a piece of brick or stone, and carry it off in her claws, making believe that it was prey of some sort. She carried on this pretense to such an extent that she would resent any interference, and would fight for her piece of brick as fiercely as if it liad been a mouse, of the delicacy of which she was most fond. No child could have "pretended" with more abandonment than she did, and the bird which "made believe" that the piece of brick was a mouse, and the child who "makes believe" that a piece of stick is a baby, are for the time, and on that point, precisely on a level.

The following account of bird humor, as displared in practical joking, is taken from Hardwicke's Science Gossip of March, 1872:

"I have imbibed many" of the tastes of Gilbert White; but that which engrosses me most, and which I may call my hobby, is the natural history of the swallow tribe.

"I have read that swallows will 'mob' and put to flight a kestrel-hawk. 'This I was rather skeptical of until lately, when my doubts were removed by that most convincing of proofs, ocular demonstration. I had gone to see an old eastle in the neighborhood, which was built on the only hill for miles around, and was therefore tolerably certain to be the haunt of a pair or two of hawks. I accordingly kept my eyes open, in the expectation of seeing one, and I was soon rewarded by the appearance on the brow of the hill of a bird which, by its graceful form and the lovering motion of its wings, I knew to be a kestrel.

"Ilis active little enemies, the swallows, a flock of which were disporting themsclves close by, had bcen as quick to see him as I. These at once adranced to meet the intruder, and, with the utmost andacity, brushed past him in all directions, one from one quarter and one from another, each wheeling after it had swept by, and returning to the charge, while the hawk made futile dashes now and again, but was always too late to do any damage to his nimble little opponents.

"At last, tired of waging an unequal war, and obliged to own himself conquered, he beat a hasty retreat. He was not, however, allowed to get off so easily, but was followed up by his victorious foes; and the apparent mystery of such little birds proring more than a match for such a formidable-looking antagonist, armed literally cap- 
a-pie, as he was, was quite cleared 11 ; f for as he made off, evidently at his best speed, the swallows, with the ntmost ease, when left at an apjurently hopeless distanee belind, fetched lim up, then passed him (in what appeared to nic most dangerous proximity), wheeled round, met him on their retmrn journey, and then, taking another sharp turn to the right about, repassed him, and continued repenting these mancurres a dozen times or more.

"The solntion of the mystery lay in their extraordinary power of flight. The way in which the swallows made straight for him, apparently bent on a personal encounter, and then, when the kestrel was reckoning on clutehing them in his talons, gliding away at a tangent, was, though no doubt tantalizing to the hawk, none the less aurusing and interesting to me.

"To crown all, when the others had left off the chase, presumably not thinking it worth their while to pursue any farther, it was eurious to watch one solitary individual carry it on alone with such seemingly unrelenting vigor that he seemed acturted by feelings of the direst revenge. However that unight be, the swallow certainly effectually prevented the discomfited foe from pausing in his enforced retreat. I watched them until pursuers and pursued both vanished from my sight. I dare say the little swallow continued the pursuit until he had wearied and exhausted the hawk.

"On another occasion I witnessed a little ineident which has, to the best of my knowledge, the merit of novelty; and so I lope you will excuse my telling it. I saw a hare rumning across a large park by the way-side, and was looking about to see what had started it, but conld not imagine what it could be, as neither man nor dog was in sight. It started again (for it had stopped and sat in a listening attitude), and then I saw that the disturbers were a flichln of swallows, who were following it up like a pack of hounds; now one and now another skimming past the hare's ears along the ground, while the poor timid creature was putting its best leg foremost; but all to no purpose, for its relentless tormentor's seemed to take pleasure in its fright, and to enjoy the sport of teasing it.

"I followed the little group until an nndulation of the park lid it from my view, and was greatly surprised to see the dexterity with which the swallows calculated their distance so as to impress the liare with the idca they were flying straight at her, and yet, when they were on the point of dashing against her, took a sharp turn, and swept off in a curve, to renew the attack again the next moment.
"I will close my epistle with an aneedote related by the Rev. Philip Skelton, as lraving come under his own observation, which seems to be appropriate, and which, I believe, will be new to most if not all your readers. I give it in his own words :

" I have entertained a great affection and some degree of esteem for swallows, ever since I saw a remarkable instance of their sense and humor played off upon a cat which lad, 11pon a very fine day, rested herself upon the top of a gate-post, as if in contemplation, when ten or a dozen swallows, knowing her to be an enemy, took it into their heads to tantalize her in a manner which slowed a high degree not only of good sense but of limnor. One of these birds, coming from behind her, flew close by her ear, and she made a snap at it with lrer jaw, but it was too late. Another swallow, in five or six seconds, did the same, and she made the same unsuceessful attempt to catch it; this was followed by a third, and so on to the number just nncutioned; and every one as it passed seemed to set up a litugh at the disapjoninted enemy very like the laugl of a young child when tickled. 'The wholc number, following one another at the distance of about three yards, formed a regular circle in the air, and played it off like a wheel at her ears for near an hour, not seemingly at all alarmed at me, who stood within six or seven yards of the post. I enjoyed this sport as well as the pretty birds, till the cat, tired ont with disappointment, quitted the gite-post, as much huffed, I believe, as I had been diverted."

The habit of "molbing" seems to be inherent in animal natme generally, and is even found in fishes, as may be seen by the following anecdote. It is related by Cilptail Crow, from personal observation :

"One morning during a calm, when near the Helrides, all hands were called $11 p$ at $3 \mathrm{~A}$.M. to witness a battle betwcen screral of the fish called thresher's, a fox-shark, and some sword-fish on the one side, and an enormous whale on the other. It was in the middle of snmmer, and the weather being clear, and the fish close to the vessel, we lad a fine opportmity of witnessing the contest.

"As soon as the whale's back appeared above the water, the threshers, springing screral yards into the air, llescended with great violence upon the olject of their rancor, and inflicter mpon him the most severe slaps with their long tails, the somnd of which resembled the report of muskets fired at a distance.

"The sword-fislı, in their turn, attacked the 
distressed whale, striking it from below; and thus, beset on all sides, and wounded, where the poor creature appeared the water around him was dyed with blood.

"In this manner they continued tormenting and wounding him for many hours, until we lost sight of him, and I have no doubt that in the end they completed his destruction."

It is worthy of notice that, in this case, a temporary alliance was formed between fishes belonging to different families. The sharks and swordfishes have but little in common, and yet they united in order to attack the whale, which could not have done any harm to either of them. It is evident, therefore, that fishes must be able to communicate ideas to each other, and to act upon those ideas. In other words, they possess a language which is intelligible to fishes in general, and not restricted to any one species. It is absolntely inaudible and unintelligible to us, but that it exists is an absolute certainty.

A still more curious alliance was mentioned to me by Captain Scott, R.N.-namely, a joint attack upon a whale by the grampus and swordfish, $i . e$. , an alliance between a mammal and a fish against a mammal.

Birds seem to be great adepts in the art of tormenting, and this talent accordingly shows itself where least expected. As a rule, domestic poultry are remarkable for the generosity with which the master-bird treats his inferiors : lie will scratch the ground, unearth some food, and then, instead of eating it himself, will call some of his farorites to him, and give to them the delicacy for which he had labored. But I knew of one case-a solitary one, I hope-where the cock scratched as usual, called his wives, and, when they had assembled round him, ate the morsel himself. It was just like the old school practical joke. Old hoy to new boy, holding out an apple: "Do you like apples?" New boy to old boy: "Yes." Old boy to new boy: "Then see me eat one."

Parrots are possessed of a very strong sense of humor, and are much given to practical joking, after the ways of mankind. My own parrot had a bad habit of whistling for the dog, and then enjoying the animal's discomfiture ; and there have been many parrots who would even play practical jokes on human beings. Dogs and cats, however, seem to be the principal victims of the parrot's sense of humor.

I know a case where a parrot is allowed to go about the house as it likes. In that house there is also a cat, with which Polly is pleased to amuse herself. One day when the cat was lying asleep on the rug, the parrot began to mew and scream th just like young kittens when they are hurt. $U_{p}$ jumped the cat, and rushed in frantic haste to her beloved offspring, and was very much astonished to find them all safe and comfortably asleep. She then returned to the rug; but as soon as she had curled herself $11 \mathrm{p}$ and settled herself comfortably, the parrot recommenced her mewings and cries, and in this way contrived to dupe the cat three times.

Every one who has watched the habits of peacocks knows the peculiar rustling sound which they can produce by shaking the feathers of their train. One of these birds, which inhabited a large yard in common with other poultry, was pleased to take nmbrage at the chickens, and amused himself by driving them about, and not allowing them to eat their food. His crowning joke was to drive them all into a corner, spread his train, and rustle the feathers over their heads so as to frighten them.

All birds of the gallinaceous order are horribly alarmed at any thing that appears above them, probably owing to their instinct which teaches them to berrare of a bird of prey. Sportsmen who have found the birds become wild and wary toward the end of the summer are well aware of this fact, and by flying a common paper kite are enabled to come quite close to the birds, which mistake the paper kite for a bird of prey, and crouch closely to the ground as long as it is above them. The peacock was therefore playing on this instinctive sense of fear when it spread its train orer the chickens.

In his "Gatherings of a Naturalist in Australia," Mr. Bennett mentions an instance of humor in an emu. A pair of these birds lived at Sydney, and were so tame that they walked about among the people who came to listen to the band. One day some persons were present who did not know the birds, and, being afraid of them, ran away. Whereupon the emus, enjoying the joke, gave chase after one of the fugitires, and took off his hat.

The same author gives a description of the beantiful species of cassowary called the mooruk. He kept a pair of them in a yard with his poultry, among whicl was a very consequential bantam cock. Every now and then the mooruk would take a fancy for chasing the bantam all orer the yard, and endearoring to trample him underfoot.

Here are two accounts of a similar mode of practical joking carried on by a dog, which I knew personally, and a horse, both belonging to the same lady: 
"We have a little Pomeranian dog, one of whose principal amusements consists in persecuting any fowls which may invade the precincts of his garden, though he nerer meddles with thein when they keep to theil own territories. His fivorite mode of torture consists in running down the nufortunate fowl, rolling it over upon its back, and then rumining round and round it. This conduct the $\log$ repeats as often as the poor victim regains its feet. Should the fowl happen to be a large Cochin or Malay, the frantic agitations of its elerated lcgs are most ludicrous."

IIorses, when kindly treated, are very fond of practical joking, from sheer exubcrance of spirits. Ignorant grooms very often are unable to understand that playfulness is not vice, and when they are brought in contact with a high-spirited, playful animal, consider it to be a vicions one, and treat it with brutal violence, thus ruining the temper of the animal. Here are somc examples of practical joking in horses:

" One of our carriage-horses, 'Charley,' although by no means vicious, was $\Omega$ saucy creature. We had much difficulty in securing him, as he could slip or untie his halter, take down the bar, and open the stable door. One day the groom forgot the necessary precaution of locking the door. Ont into the yard walked Charley, where he found the coachman's little boy. The animal did not attempt to hurt the child, bnt (witl that feeling which canses great boys to find amusenent in teasing younger ones) drove him into a corner, and seeing that the little fellow was frightened, kept him there by shaking his head at him whenever he attempted to escape. I happened to be the first person who discorered them, and, although but a child myself, went to the rescue.

"I knew the animal's funny tricks, and he knew that I was not afraid of him; therefore he allowed me to lead him back to the stable, only giving a parting shake of the head to his late prisoner. Although so fond of liberty himself, he would thus imprison dogs, cats, or fowls whenever an opportunity offered."

One of my friends, when a boy, had a Shetland pony, whose idea of humor consisted in throwing every one who got on his back; and the variety of means which he conld employ showed a wonderful readiness and fertility of invention. Having heard the owner of the pony tell a few anecdotes of his former farorite, I askcd for further details, and received from the old coachman of the fumily the following account, which I print exactly as it was witten:
"In the year 1S11, 2, 3, The P- Fox Hounds was kept at $K-$, J. G., Esq., master of them. 'There was three young Gentlemen, sons of MIr. G. 'They had each Poneys for hunting. MIr. F. was the eldest, then Mr. C. and Mr. A. Mr. F. twelve years of age, Mr. C. ten, and Mr. A. nine. 'The Poneys wals kept rough, never in a Stable; they ran out in the Park summer and winter, had a slied to go into at night; they got a little Corn and Hay in winter, that was all the Grooming they got. One of them named 'Tom tit was rather a rum onc to ride; he was about ten hands High, a dark Bay with Black Points, Carraed very little flesh, more like a roe deer than a Poney; his rider was Mr. C. At that time his weight would be about 6 Stone. None Could ride him but him self. I reniember of 5 of the Stable Lads trying to ride him in the Park anongest the rest I was one. No sooner did wc get on to him then he Pitched every one of lis orel his head. Of Course we had no Saddle.

"I liare seen Mr. C. get on to him in the Stableyard, and the first thing he would try to do was to Pitch him over his head; having failed in that, he would try to rub him off against a wall or house, thinking he had got his leg betwixt him and wall; but $\mathrm{Mr}$. C. was too wide awake for him, the moment he saw what he was up too he put his leg up on his neck, then having faild there, he maid for the Coachhouse wich was verry narrow, Just room enough to let a Man in along side of Carriage, he would get in there trying first the wall and then against the Carriage; he had not room enough to turn to get out, so that some of us would lift him and his rider out withont any Damage being done; then having fitild in all these atemps, he ran off Past the Mansion house; there is a burn runs Close Past the house, a Bridge over it, and then a gate about 4 feet High, and wich he maid an atemp to Jump, he got his fore legs orer the tope bar np as far as the knees and he was fixed he Conld nether get one way nor another, he was Standing on his hind feet almost as Straight as a man and his rider Still in the Saddle. I run up to him and said, What are you doing there? II rider said, I know what, he wants me oft some way or other, so must Just get down when he had the boldness to get up, I will not Come off: so I lifted the two off the Gate. I lave seen lim when in a run with the IIounds go through a hole in a hedge you would think not large enough to let one of the Hounds. He was rery Seldom thrown out of a rum, he Could gallop like a race horse; very Good for soft gromnd. being so light. I rcmember of the groing a-miss- 
ing all in a sudden so ther were both lost. Mr. G. called out, C., were are you? The answer sounded near where were Standing I hear they were both lying in a ditch up to the neck in water, and Poor C. and Poney had to go home very nuch aganst there will."

The sime pony was afterward sold and taken away. However, when he was some five or six miles away, he had recourse to his old tricks: he sent his rider over his head, gailoped off, and jumped several walls, swam the river Ean, and presented himself at his old quarters.

The "Mr. C." mentioned by the coachman tells me that the perpetual struggle for mastery wals nothing bnt pure fun on the part of the pony; but that if he had once dismounted, eren when in such absurd positions as those which the coachman so well describes, the pony would have been master ever afterward.

Last summer I was witness to a scene showing that the horse possesses a strong scnse of humor. I was walking through Barfreyston, a village near Dover, and saw over the rather high wall of a firm-yard a eouple of horses careering about madly. The wall was so high that only their heads could be seen, and occasionally a whisk of their tails. Finding an aperture through which I eould look without being seen, I fonnd that the horses were amusing themselves by chasing a pig, hunting it round and round the yard, driving it into corners, and occasionally flinging their heels into the air with delight.

They scarcely gave that wretched pig any rest. Sometimes, when tired with their exertions, they would lie still for a few minutes, and the pig would get away as far as possible from his tormentors. But no sooner did the poor animal settle down to a cabbage leaf than the horses would be at him again, driving him about, and putting him in such a state of perturbation by chasing hin from different directions that he had not the least idea where to run so as to escape his tormentors. 'The horses, in fict, were acting just as two school-boys might be expected to do if a pig's adverse fate had delivered it in their hands.

Many of the lower animals not only show their playfulness in such tricks as those which have been mentioned, but are able to appreciate and take part in the games played by children. When I was a boy I knew a little dog, a King Charles spanicl, which was an accomplished player at the well-known game called tag, or touch. The little animal displayed quite as much enthusiasm as any of the human players, and would dart away from the boy who happened to be "touch" with an anxicty that almost appeared to be terror. Of course to touch the dog was an impossibility; but he was a generous little creature, with a strong sense of justice, and so, when he thought that his tuln onght to eome, he stood still and waited quietly to be touched. His mode of touching his playfellows was always by grasping the end of their trousers in his teeth; and as it was impossible for the boy to stop when so seized in full course, the dog often got jerked along the ground for some little distance.

A lady told me lately that, when a girl, she had a pony which would play hide-and-seek with the children. Hiding was necessarily only a pretense on the part of the pony; but the animal would go to some corner, hide its head, and make believe that it was entirely concealed.

Hide-and-seek seems to be a game which can be learned and enjoyed by many animals. One of my correspondents has sent me an account of a favorite cat which was an adept in the game. She was a white cat with yellow eyes, and went by the name of "Daisy." She was given, when quite a little kitten, to her mistress, who was then a young child, and the two becime inseparable companions, joining in their sports, one of which was hide-and-seek.

The littlc mistress used to hide, and the kitten to search for her, invariably discovering her lurking-place.

One of the most curious points in this animal was that when she became a cat and had a kitten of her own, she taught her young one the game which she had learned from her mistress, importing into the game an element which I have over and over again seen in the same game when played by children. The kitten went and hid itself, or rather pretended to hide, and the mother went in search of it. She would pretend not to see the kitten, and pass close to its hidingplace. 'Then, as if startled, she wonld spring back, the kitten would jump out at her, and the two would rush about in high glee.

'The readcr can compare with this story the anecdote of "Pop" and the hidden ker, which will be found in another part of this work.

A somewhat similar aneedote is told in the Zoologist, page 9430, of a short-tailed field-mousc, which had been tamed. It was found so covered with ticks that it conld hardly cravl. It was picked up, cleared from the vermin, and placed in a box. It was so grateful for the relief that 
it did not try to escape, and on the very first in these gambols, that when standing on the day took food from the hand of its benefactor.

"Little 'Peter,' as he was named, soon learned to come when called, and was let out of the box every day to play about the room. Strange to say, he showed a decided appreciation of fun, a farorite amusement being to hide himself in a basin of corn which was kept for lis benefit. In this he would bury liniself, refusing to answer to his name, and evidently expecting to be looked for. If my friend took no notice of him, Peter's slender stock of patience soon became exhausted; first a slirill squeak was heard, then the corn flew up in showers, and at last up came Peter's little round head to the surface."

This interesting little animal died from feasting too freely on a pear which had becn injudiciously given to it by one of the servants.

I). Bennett, in his "Gatherings of a Naturalist in Australia," mentions that a couple of young duck-bills in his possession used to play at hideand-seek behind the furniture of the room. One would hide itself and then give a squeak, when the other would hunt for it and at last find it.

'The reader will remember that a kestrel possessed the same powers of "making believe," pretending that a piece of brick was a mouse, and fighting fiercely if any one offered to take it away.

Not eren the huge and unwieldy whales are exempt from the sense of humor as displayed by playfulness. In Bennett's "Whaling Voyage" there is a short and graphic description of this trait of character in the spermaceti-whale, or cachalot, as it is often called:

"A large party of cachalots gamboling on the surface of the ocean is one of the most curions and imposing spectacles which a whaling royage affords; the huge size and uncouth agility of the monsters exhibiting a strange combination of the grand and ridiculous.

"On such occasions it is not munsual to observe a whale of the largest size leap from the water with the activity of a salmon, display the entire bulk of its gigantic frame suspended at the height of several feet in the air, and again plunge into the sea with a helpless and tremendons fill, which causes the surrounding walters to shoot up in broad and lofty volumes capped with foam.

"Others of the same 'school' leap or 'breach' in a less dcgree, sportively brandish their broad and fan-shaped flukes in the air, or protrnde their heads perpendicularly abore the waves like columns of black rock."

Captain Scott, R.N., once told me, as an example of the height to which a cachalot will leap deck of a man-of-war, he has secn the horizon under the animal before it fell again into the water. When we recollect that thcse whales often reach eiglity feet in length, we may alppreciate the force which is exerted in projecting this huge mass to such a height.

Here are two instances of humor as exhibited by birds, and showing playfulness without any desire to cause personal annoyance:

Two ladies were sitting at work in a room in which was a pet can:ry belonging to one of them. The bird threw a reel of cotton on the floor, took the end of the thread in its beak, and wonnd it first round the neck of one lady and then round that of the other, until the reel was empty, when the bird perched on a chair, and seemed quite pleased with its freak.

The lady to whom the bird belonged tried to unwind the thread from her neck; but every time that she attempted to remove it, the canary flew at her and flapped its wings in her face, so as to prevent her from freeing herself.

A young lady, who was considered as the mistress of a bull-finch by every one except the bird himself, sends me the following account of her pet's sense of humor, which was developed, as is usual among the lower animals, in the form of a practical joke:

"One day while 'Bully' was flying about the dining-room mamma went out of the room, learing on the table her work-box, in which was a little pincushion stuck full of needles already threaded, besides pins. Bully knew that he was not allowed to touch the pins; but as soon as mamma left the room he pulled all the pins out of the pincushion, and scattered them abont the tablecloth. The needles lie carried to the top of the lamp, and twisted the thread round a part of the lamp. He then put the pincushion under the sofa, and retired to the lamp, where he waited until mamma came back."

It is really a remarkable fact that these two birds, each belonging to the finches, should have played similar practical jokes with thread, i.e., twisting it about some object where it had no business to be. I ought to add that the story of the canary was sent to me only a few days ago, while no less than thirteen years have elapsed since the anecdote of the bull-finch was sent. It had been put away in a box, and was only found an hour or two before this present time-11.25 A.M., January S, 1874.

In Bennett's "Wanderings in New South Wales" there is a singulurly interesting history 
of the life and death of a Siamcse ape, which went by the name of "Ungka." He was a playful animal, and sometimes, when he conid not find a human playfellow, he would try to make companions of some small monkeys that were on board the same ship. He was too big and black for them, howerer, and they united together for the purpose of driving him away.

"Ungka, thus repelled in his kind endeavors to establish something like sociality among them, determined in his own mind to annoy and punish them for their impudence. So the next time that they united as before in a body on his approach, he watched the opportunity, and, when one was off his guard, seized a rope, and, swinging toward him, caught him by the tail and hauled away upon it, much to the annoyance of the owner, who had no idea that such a retaliation was to takc placc. He continued pulling on it as if determined to detach it, until the agility and desperation of the monkey at being so treated obliged him to relinquish his hold.

"But it not unfrequently happened that he made his way up the rigging, dragging the monkey after him, and thus made him follow his course most unwillingly. If, in his ascent, he required both hands, he would pass the tail of his captive into the prchensile palm of his feet. It was the most grotesque scenc imaginable, and will long remain in the remembrance of those who witnessed it. It was performed by Ungka with the most perfect gravity of countenance, while the poor suffering monkey grinned, chattered, and twisted about, making the most strenuous efforts to escape from his opponent's grasp.

"His countenance, at all times a figurc of fun, now had terror added to it, increasing the delineations of beatuty; and when the poor beast had been dragged some distance up the rigging, Ungka, tired of his labor, would suddenly let go his hold of the tail, when it would require some skill on the part of the monkey to seize a rope in order to prevent his receiving a compound fracture by a rapid descent on deck. Ungka, haring himself no caudal extremity, knew well that he was pcrfectly free from any retaliation on the part of his opponent."

After this the small monkeys had a consultation, and agreed that whenever Ungka assanlted either of them, they should all unite in attacking him. This, by the way, is another proof of langnage and power of combination among animals, as mentioned in Chapter V. Having acquired a taste for tail-pulling, and finding it unsafe to attack the monkeys, Ungka took to pulling the tail of the ship's pig, trying, but in vain, to straighten it.

We shall hear something more of this animal in connection with the subjects of Pridc and Conscience.

Some persons have asked me what use the capacity of humor could subserve in the next world? I suppose, much the same that it subserves in this. For my own part, I should extremely regret, were it possible, to lose my sense of humor whenever it may please my Maker to summon me into the spirit-world. There are some, even in this world, in whom the sense of humor scems to be absolutely wanting, and, however estimable they may be in character, they arc just solemn prigs. I should be sorry to resemble them in the next world. 


\section{CIIAPTER XI.}

\section{PRIDE, JEALOUSY, ANGER, REVENGE, TYRANNY.}

Pride, or Self-esteem, among Animals._Etiquette in the Cow-shed.-Pride of Ancestry in the Mrule.-Different Positions of the IIor'se and the Ass among Mrules.-The "Bell Mare" and her Value to Muleteers.Animals Sensitive to Ridicule._" Pret's" Objection to Dispar"aging Remarks._Dislike of Ridicule Shown by "Ungkia."-Pride in Personal Appearance.-The Peacock, the Turkey, the Whidah-bird, and the Birdof-Paradise.-Jenloosy and its Developments.-Definition of the Two Kinds of Jealousy.-Jealousies between Pets._-"Zeno," "Direl," and their Aquatic Rivalries.-Jealousy of a Dog, accompanied by AxGER, and followed by Revenge.-The Brown Mouse and its White Rival.-Jealonsy and Delayed Revenge among Poultry.-The Love-drama of the Mandarin Duck, and its Adaptability to the Stage.-Comparison with Human Beings._-Trranx among the Animals. - Tyramuy in the Tiger-beetle. - The IIermit Crabs and their Conflicts.-Tyranny among Gregarious Animals and Birds.-The Tyrant and the Irarem.-Comparison with Polygamous Man._Tyranny in the Aviary._Tyranny of Pets._ "Duchie" and her Mistress.

THE five characteristics which head this chapter are not pleasing; but, such as they are, they belong to the immaterial, and not the material, part of man. We shall see that the lower animals also possess these qualities, and the inference to be drawn from that fact is obvious. We will take those characteristics in order.

Pride, or self-esteem, is developed as fully in many animals as it can be in the proudest of the human race. This is shown most conspicuously in animals which herd together. There is always one leader at the head, who will not suffer any move to be made without his permission, and who resents the slightest interference with lis anthority. Especially is this the case with the deer tribe, the horses, and the oxen. Eren when these latter animals are domesticated, and the habits of their wild life are materially changed, the feeling of pride exists to the fullest extent.

I have often amused myself by watching the inhabitants of a farm-yard, and seeing how the cows have their laws of precedence and etiquette as clearly defined as those of any European court. Every cow knows her own place and keeps it; she will not condescend to take a lower, and would not be allowed to take a higher. When a newly bought calf is first introduced to the farm-yard, it is treated just like a new boy at school. The previous inhabitants of the yard come and inspect it contemptuously, they decline its society, they crowd it away from the lay-racks; and a new-comer in a farm-yard laas about as much chance of approaching the rack at feeding-time as a new boy has of getting near the fire on a cold winter day.
However, as time goes on, the young calf increases in growth, and is allowed to mix with her companions on tolerably equal terms. Then, if a younger animal than herself be admitted, it is amusing to see with what gratification she bullies the new-comer, and how much higher she seems to rank in her own estimation when she is no longer the junior. Should the fates be propitious, she arrives at the dignity of being senior cow, and never fails to assert that dignity on every occasion. When the cattle are taken ont of the yard to their pasture in the morning, and when they return to it in the erening, she will not allow any except herself to take the lead. I have heard of one instance where the man in charge of the cows would not allow the "ganger," as the head cow is often called, to go out first. The resnlt was that she refused to go out at all; and, in order to get her out of the yard, the man had to drive all the other cows back again, so that she might take her proper place at their head.

In great portions of this country we make little lise of the mule, and its real disposition is not generally known. Those, however, who have been forced into long companionship with this animal have always observed some very curious traits of character in it. Judging from popular ideas respecting the mule, we might think that the animal had no pride in its composition; whereas it is in reality a very proud animal, and fond of good society, as is slown by the following extract from Froebel's "Seren Years in Central America:"

"From drivers and muleteers we may pass to 
mules, which are in many respects far more interesting than the former, and whose natural disposition is an attractive subject to the observer of nature.

"One of the most striking characteristics of the mule is his aversion to the ass, and the pride which he takes in his relationship to the loorse, which instincts are met with obtrusiveness in the ass and by indifference in the horse. If an ass at any time, urged by the vanity peculiar to its race as related to the mule, happens to fill in with a drove of mules, he will, in all probability, be kicked and lamed by his proud relations. A horse, on the contrary, takes a distinguished position in a drove of mules. The latter crowd around him and follow his movements, exhibiting a violent jealousy, each striving to stand nearest to their distinguished relative.

"This instinct is employed to keep together" a drove of mules on a journey or at pasture, by putting a milre to the drove, witl a bell around her neck, and called the 'Bell Mare;' by the Mexicans, 'Layegua Madre,'i.e., the mothermare. 'This animal is led day and night by a cord, and the whole drove is thus kept under "ontrol, and will not leave their queen. It is, thercfore, very difficult to separate the drove. 'The man who leads the mare is instructed, in case of an attack from the Indians, to leap instantly upon the back of this animal, and take refuge in the wagon encampment, whither the drove is sure to follow him.

"Even if the Indians succeed in separating any mules from the drove, they find it difficult to carry them off. 'The animals incessantly attempt to turn back, and the travelers are thus enabled to overtake the robbers, and recover the stolen animals. The Indians, in consequence, use every means to get possession of the mare, and, if they succeed in this, the whole drove is lost to their owners. If several horses are in a drove of mules, the danger is that the latter become dispersed; and this is the reason that, in these journeys, saddle horses are not allowed to go loose, but are led by a cord."

It is rather curious to trace among the lower animals a feeling which bears a very close resemblance to pride of birth among mankind.

Pride shows itself in many ways, both in men and animals. Here we have pride of rank and love of precedence annong cows, and pride of ancestry among mules. Sometimes pride takes the form of sensitirencss to ridicule. 'There is nothing so galling to a proud man as to feel himself the object of ridicule, and precisely the same trait of character is to be found in many animals.
As may be expected, this form of pride is mostly dereloped in the domesticated animals; or, perhaps, it is in those that we have most opportunities of observing it.

My cat, "Pret," for example, was peculiarly sensitive to any thing approaching ridicule. He was quite conscious if we spoke of lim in a disparaging manner, and testified his disapprobation after his own manner. But to laugh at him was an insult which he could not brook, and, if we continued to do so, he would arch his tail, hold himself very stiff indeed, and march slowly out of the room. How sensitive all high-bred dogs are to ridicule is so well known that we need not occupy space by citing examples.

The Siamese ape "Ungka," a part of whose history has already been given in connection with the subject of Humor, possessed a keen sense of ridicule. 'The animal was exceedingly tame, and at meal-times always came to take his share, a corner of the table being appropriated to his use. "When, from any of his hudicrous actions at table, we all burst out in lond laughter, he would rent his indignation at being made the object of ridicule by uttering his peculiar hollow barking noise, at the same time inflating the airsac, and regarding the persons laughing with a most serious look until they had ceased, when he would quietly resume his dinner."

Pride in personal appearance, or vanity, is often to be seen among the lower animals, more especially among those birds who are notable for bright or abundant plumage.

Any one who has seen a peacock in all the glory of his starry train will recognize the intense pride which the bird feels at his own splendor. He does not only display lis magnificent train for the purpose of attracting the homage of his plainly clad mates, but seems to be just as prond of the admiration bestowed by human beings as of that offered by his own kind.

Nor does he despise the homage of birds whom he considers his inferiors. Only a few hours before writing these lines I saw a peacock, with his train fully spread, displaying all his grandeur around a dozen barn-door forls. He stalked majestically among them, scarcely deigning to look at them, but turning round and round so as to display his grandenr to the best adrantage, and apparently as satisfied with the effect which he produced as if he had been surrounded by his own kind.

Then there is the turkey, whose movements are so grotesque when he is strutting about in his nuptial plumage, and who surveys himself with ludicrous complacency. 'Taking the well- 
known whidah-bird (or widow-bird, as it is often (alled), we see this trait of character highly dcveloped. IIe is wonderfully proud of his beautiful tail, and, as long as he wear's it, loses no opportunity of displaying it to every visitor who approaches his cage. But when the moulting the season comes, and he assumes for a while the plain, tailless suit of his mate, his numner is as changed as his appearance, and, instead of exhibiting himself in all his pride, he mopes about with a dull and listless demeanor, and seems absolutely ashamed of his mean condition.

It might be expected that so magnificent a creature as the bird-of-paradise would have its full share of pride; and that this is the case is shown by the account of a tame specimen in Bennett's "New South Wales," to which reference has already been made:

"One of the best opportunities of seeing this splendid bird in all its beauty of action, as well as display of plumage, is early in the morning, when he makes his toilet. The beautiful subalar plumage is then thrown out, and cleansed from any spot that may sully its purity by being passed gently through the bill. The short chocolate-colored wings are extended to the utmost; lie keeps them in a slowly flapping motion, as if in imitation of their use in flight; at the same time raising up the delicate long feathers over the back, which are spread in a chaste and elegant manner, floating like films in the ambient aiir.

"In this position the bird would remain for a short time, seeming proud of its hearenly beauty, and in raptures of delight with its most enchanting self. It will then assume various attitudes, so as to regard its plumage in every direction.

"I never yet beheld a soil on its feathers. After expanding the wings, it would bring them together so as to conceal the liead: then, bending gracefully, it would inspect the state of its plumage underncath. 'This action is repeated in quick succession, uttering at the same time its croaking notes. It then pecks and cleans its plumage in every part within reach; and, throwing out the elcgant and delicate tufts of feathers underneath the wings, seemingly with much care and not a little pride, they were cleaned in succession by throwing them abroad, elevating, and passing them in succession through the bill.

"Then, turning its back upon the spectator, the bird repeats the actions above mentioned, lut not in so careful a manner; elevating its tail and long shaft feither's, it raises the delicate plumage of a similar character to the sub-alar, forming a beatutiful erest, and, throwing its feathers up with much grace, alpears as proud as a lady in her full ball-dress. Having completed the toilet, it utter's the usual cawing notes, at the same time looking archly at the spectators, as if ready to receive all the admiration that it considers its elegant form and display of plumage demand. It then takes exercise by hopping in a rapid but graceful manncr from one end of the upper perch to the otlier, and descends sudienly upon the second perch, close to the bars of the cage, looking out for the grasshoppers which it is accustomed to receive at this time."

Here we have the character of pride in personal appearance developed as strongly as it could be in any human being. Moreover, the bird could sufficiently enter into the feelings of the spectators to understand that they were admiring its bcauty, and to exult in that admiration.

\section{JEALOUSY.}

Jealousy is of two kinds, one connected with. the love of some other being, and the other depending on the love of self. The former is this defined in Webster's Dictionary: "That passion or peculiar uneasiness which arises from the fear that a rival may rob us of the affection of one whom we love, or the suspicion that he has already done it." The latter is thus defined: "The uneasiness which arises from the fear that another does or will enjoy some advantage which we desire for ourselves." We will only deal with the former of these traits of character.

In the first place, it is erident, from the definition which las just bcen given, that jealousy implies the power of reasoning, and that any creature by which it is shown must be able to draw a conclusion from premises. Perhaps the animal is wrong in its conclusion; but the process is still one of reasoning, however incorrect that process may be.

All persons who have possessed pet animals must be familiar with the excecding jealousy displayed by most of them. This feeling is manifested most strongly when an animal has been the only pet, and another is introduced into the honse.

My own cat, "Pret," resented so strongly the advent of a Skye terrier, that when the dog came into the house he walked ont, and never would enter it again. He had already put up with a baby, which was a very great trial to his feelings; but a dog was more than he could en- 
dure, and so he retired to his own house in the and well did he know he was doing wrong. He garden, and lived there alone. His affection for would sneak up behind me, afraid almost to show me remained unchanged, and he was only too himself; but whenever I gave him a sign of kindhappy when I went into the garden. But he ly recognition he became quite frantic and orerheld the honse deseerated by a dog, and, even joyed; in an instant, however, he was at my when hungry, could not be allured within the heels. door by the offer of food.

Not that he had any personal objection to the dog; on the contrary, the two animals were very friendly with each other, even eating ont of the same dish. But Pret considered that "Bosco" had $n$ right to me, and whenever I came on the scene, Bosco got his ear's boxed, and had to retire into the backgromud. So absurdly strong was this jealous feeling, that whenever I wanted Pret to come quickly, I used to call Bosco; which ruse always had the effect of bringing Pret along at full speed, in order to anticipate the $\operatorname{dog}$.

One of my neighbors has a couple of little dogs-"Bell," a black-and-tan toy terrier, and "Fay," a cross between Skye and Maltese. These two animals are the best of friends, always lying on the same mat, which they share with an enormous cat called "Tommy." But, with regard to their human friends, their jealonsy of each other is extreme. They do not seem to care if notice be taken of the cat; but if Bell be caressed, Fay is sure to sidle up and try to interpose herself between Bell and the caressing hand. Bell is equally jealous, but shows her feeling by noisy and angry demonstrations of assault, which, however, are never earried into effect.

I suppose that most of my readers who have possessed two or more dogs at the same time must have been amused at the boundless jealousy which they will display toward each other while engaged in the service of their master, thongh at other times very excellent friends. Such scenes as the following are of frequent occurrence, and are instructive as well as amusing:

"I have in my possession a farorite dog called 'Zeno' (from the Greek philosopher); his age is over seventeen years; he is a eross between an otter terrier and a Scotch.

"There never was a cleverer log. He is passionately fond of the gun ; and though rery serviceable in the field, still I disliked to have him when pointers were at work. He was the finest retriever I ever saw, and if there was a womnded bird, hare, or rabbit, if he were allowed, he would find it, go where it might be, eren into the sea. Wherever I went to shoot, he was sure to find me, no matter whether I walked, drove, or rode. I have seen him come up to me of an afternoon, when he must have traveled seven or eight miles,

"A farorite amusement of mine was to shoot wild-fowl and teal in the Frith of Forth. I used to take Zeno and a large Newfoundland, named 'Diver,' with me.

"Zeno was erer on the watch, and, whererer I killed the bird, it was amusing to see the two plunging into the wares, and racing to get first to it. Zeno generally picked up the bird, haring no heary coat to impede him; but Diver often thought that he should have the honor of carrying it, and would attempt to take it from himbut it was of no use. The battle often became fierce, the little dog dropping his game, flying at the larger one with all his fury, then, picking up his bird, would paddle his way to the boat-side, look up in my face as if saying, 'Have I not done well ?' and then I would help him up, when the two were as good friends as ever."

The power of jealousy and anger is well shown by the following anecdote of a pet dog. I knew the animal well, and his mistress wrote the little history at my request:

"One of our pet dogs, of a mixed breed, with long white hair, was, in common with most pets, of a very jealous disposition, always showing displeasure if any other living thing obtained a share of that attention whieh he considered exelusively his own.

"One wintry morning a poor little infantine duck that had been injured was bronght into the house to be nursed and tended. 'I'he dog watched all the attentions bestowed upon it, was eridently annoyed at the intrinsion of a rival where he had rnled supreme, and rowed vengeance.

"After a few days the duck mysteriously disappeared. The dog was suspected, but neither dog nor duck could be found. Just before dark a more minute search was made in the house and garden, and at last something was visible under a large rose-tree. 'There stood the culprit, shivering with cold, his nose and paw's all covered with med, and at his feet was a half-filled grave, in which was deposited the body of the murdered duek.

"His long hair had become entangled in the thorns of the rose-tree while he was engaged in burying his victim, and fear of deteetion and reproof had cansed him to remain a silent captive for so many hours. IIis pitiful condition dis- 
armed our censure, for he was so firmly fixed that the gardener had to cut of the rose-branch, so that it might be more leisurely disentangled in the house. Before this event the gardener had not been a favorite with the dog, but ever afterward it seemed to feel itself owing a debt of gratitude to its cleliverer."

The dog in question lives at Canterbury, where his intellect and accomplishments have made him well known.

We see in the behavior of the animal, not only jealousy, but memory, hatred, and revenge, and a sense of moral responsibility. 'The remembrance of the farors lavished on his rival rankled in his memory, and the result was hatred culminating in revenge when he found an opportunity. 'Then he knew that he had done wrong in killing the duck, and, just as a man would do who had committed a murder, tried to conceal the evidences of his erime by burying the body of his victim. So deeply was his conscience pricked, that, when he fonnd himself arrested by the bush, he ran the risk of dying of cold and hunger rather than allow himself to be discovered.

Even in such rarely tamed animals as the common mouse the feeling of jealonsy has been known to be so strong as to leird to murder. A young lady, one of my correspondents, had succeeded in taming a common brown mouse so completely that it would eat ont of her hand, and allow itself to be taken off the floor. She had also a tame white mouse in a cage.

One morning, when she went to feed the white mouse as usual, whe found it lying dead on the bottom of the cage, and beside it was its murder$\mathrm{er}$, the brown mouse. The cage being opened, the latter made its escape, but how it had contrired to gain admission was a mystery.

An instance has lately come to my knowledge where jealousy was restrained for a eonsiderable time through fear, and at last broke out when the cause of fear was removed. 'The story is told by a lady living in Edinburgh :

"I remember" a Malay cock of mine manifesting a mixture of hatred and revenge to a dead rival, equal in fury, if not in power, to what a Malay man, in similar circumstances, might have shown.

"We had a very splendid dunghill eock, who kept the Mralay (a cowardly eaitiff) in great subjection. This cock died suddenly. His rival eame by chance on his dead body. He instantly sprung on it, kicked, spurred, and trampled upon the lifeless bird, and, standing upon the corpse, flapped his wings, and erowed himself hoarse witl the most disgusting energy.
"The rascal took instant possession of the harem, and I often thought that the hens must sadly have missed their old lord. He always used to share any titbits witl them-a practice carefully aroided by his successor, the Eastern despot, who greedily kept the best to himself."

Again, comparing man with beast, we see that the bird in this ease acted exactly as a savage does when his enemy has fallen. The savage exults orer the dead body of an enemy, especially if that foe has been very formidable in life, and mutilates in futile revenge the form which he feared when living.

Take the following story, which is related in Bennett's "Wanderings in New South Wales," transform the aetor's into human beings, and see how exactly the birds acted like human beings, and how the plot of a powerful drama might be constructed from the story. The birds in question were the beautiful little "Mandarin" ducks, which even in China are exceedingly valuable. They are proverbial for their conjugal fidelity, and in marriage processions a pair of these ducks are carried about as emblems of the love which ought to animate the newly married couple.

"The following circumstance of fidelity was mentioned to me as having occurred in two birds of this species :

"A dirake was stolen one night, with some other birds, from Mr. Beale's aviary. The beautiful male was alone taken, and the poor duck was left behind. The morning following the loss of her husband, the female was seen in a most disconsolate eondition; brooding in secret sorrow, she remained in a retired part of the aviary, pondering orer the severe loss she had just sustained.

"While she was thus delivering her soul to grief, a gay, prim drake, who had not long before lost his dear duck, which had been accidentally killed, trimmed his beautiful feathers, appeared quite handsome, and, pitying the forlorn eondition of the bereaved, waddled toward her, and, after deroting much of his time and all his attention to the unfortunate female, he offered her lis protection. She, however, refused all his offers, having made, in audible quacks, a solemn vow to live and die a widow if her mate did not return.

"From the day on which she met with her loss she neglected her usual arocations, forsook her food and usual scenes of delight, where she loved to roam with him now absent, and to excite his brave spirit to drive away all the rivals that might attempt even to approach them. But 
those fleeting hours of enjogment had passed, perhaps never to return, and no consolation that could be offered by any of her tribe had the least effect. Every endearor was made to recorer the lost bird, as it was not expected that the beautiful creature would be lilled.

"Some time elapsed after the loss, when a person, accidentally passing a hut, overheard some Chinese of the lower class conversing together. He inderstood sufficient of their lamguage to find out that they said, "It would be a pity to kill so handsome a bird.' 'How, then,' said another, 'can we dispose of it ?' The hut was noted, as it was immediately suspected that the lost Mandirin drake was the subject of the conversation. A servant was sent, and, after some trouble, recorered the long-lost diake by paying four dollars for him. He was then brought back to the aviary in one of the usual cane calges.

"As soon as the bird recognized the aviary, he expressed his joy by quacking vehemently and flapping his wings. The interval of three weeks had elapsed since he was taken away by force; but when the forlorn duck heard the note of her lost husband, she quacked, even to sureaming with ecstasy, and flew as far as she could in the aviary to greet him on his restoration. Being let out of the cage, the drake immediately entered the aviary, and the unfortunate couple were again united. They quacked, crossed necks, bathed together, and then are supposed to have related all their mutual hopes and fears during the long separation.

"One word more on the unfortunate widower who kindly offered consolation to the duck when overwhelmed with grief. She, in a most ungrateful manner, informed her drake of the impudent and gallant proposals he made to her during his absence. It is merely supposition that he did so; but, at all events, the result was that, on the day following his return, the recorered drake attacked the other, pecked his eres out, and inflicted on lim so many other injuries as to occasion his death in a few days. Thus did this unfortunate drake meet with a premature and riolent death for his lindness and attention to a disconsolate lady. It may perhaps be correctly written on his grave, "A victim to conjugal fidelity." "

The very same feelings which would have actuated human beings under similar cireumstunces influenced these birds. There is conjugal love affected by sudden and riolent separation; there is conjugal fidelity in absence; there is sorrow for the loss of one who is loved; there is joy in reunion; there is jealousy at an attempt to steal the affec- tion of a partner; and, finally, there is revenge swiftly taken upon the offender. There also is the power of language, as, withont a resy definite language of her own, the duck could not have told her partner of a particular drake, and so drawn upon him the vengeance of her husband.

\section{TYRANNY.}

Another of the many traits of character which are common to man and the lower animals is tyranny, i.e., the oppression of the weak by the strong, whether that strength belong to the body or the mind. In many of the animals, tyramy takes its most obvious form, the strong not only oppressing the weak, but killing and eating them, even though they be of the same species. A human cannibal acts just in the same way, eating his enemy after he has killed him.

As to the milder forms of tyranny, there is scarcely an animal in which it may not be fonnd, and it is manifested quite strongly in the insects. There is a notice in Hardwicke's Science Gossip, for October, 1871, of tyranny shown by a tigerbeetle toward its fellows, one insect assaulting another, and driving it away, "much in the same manner as sparrows do when they have secured some morsel of food which they wish to keep to themselves."

In the Daily News of November, 1873, there was a brief and amusing account of tyranny as shown by crabs. The writer had been observingr the proceedings of the creatures in the Brighton Aquarium :

"It is well worth while to watch the movements and manourres of the hermit crab. He is discerning, has a keen eye to his own conlrenience, pngnacious when any one comes between him and the object of his desire, and unrelenting in following np his advantage. He contends for some practical and substantial end, pursuing conquest not for the sake of the bare submission of his adversary.

"These remarks are induced by our own observation of the amusing habits of this little animal. Some time back we were, one bright morning, watching the beantiful gleam of the herring, as its scales reflected the sunshine in raried colors, which played into one another, reminding one of a benutiful 'shot' silk dress. Our attention was suddenly attracted by a commotion among the hermit crabs, many of which are in the same tank with the herrings.

"These crabs, as is generally known, have re- 
course to the cover of a whelk, or other shell, to protect the abdomen, which is very soft and vulnerable. Suddenly one of the number, a large specimen, whose adopted dwelling was of somewhat narrow dimensions, gave chise to a small crab which occupied a shell much larger than that of his bigger neighbor. 'The little one, alpparently quite alive to the sinister intentions of his purster, took to flight as quickly as possible, and his attempts to escape were continued with the ntmost vigor until further eftort was hopeless. The way in which he dodged around and behind oysters, and whatever afforded him a temporary corer, was amusing in the extreme.

" $A$ t length he was orertaken, and then a regular pitched battle ensucd. The little one resisted manfully, but was finally orercome, the more bulky combatant having, after the most strennous exertions, snceeded in forcing his claws between the body of his weaker opponent and his adopted shell, and with the most frantic exertion turning him out. 'They then, apparently as a matter of conrse, exchanged shells, the ousted tenant yielding submissively to his fate, and quietly adapting himself to his reduced circumstances. In this encounter, from beginning to end, all the qualities we began by enumerating were exemplified in these little creatures-the discernment with which the larger crab fixed upon the shell which exactly suited him, the determination with which he followed up his intention of possessing himself of it, and the pugnacity and perseverance displayed by both in the course of the encounter.

"This was evidently no fight for inere fighting's sake; but the whole proceeding evinced a settled plan, pursued, on the one hand, with the greatest determination, and, on the other hand, met with the most obstinate resistance."

I have often witnessed similar scenes, not only in the Aquarium, but in the rock pools along the coast.

Tyranny is invariably seen among gregarious animals, the herd or flock being always under the command of one individual, who has fought his way to the front, and who will rule with imperious sway mintil he becomes old, and inturn is ousted by a younger and more vigorous rival. The same quality is rery familiar to us in our poultry-yards, where, no matter how many may be the number of birds, one cock invariably assumes the leadership.

As a rule, he takes his honor's meekly, but bases his conduct on the old Roman principle, "Parcere subjectis, sed debellare superbis."
'There are mostly one or two younger cocks, with whom he does not interfere, unless they attempt to dispute his sway, or-most umpardonable offense of all-to win the affections of any of his liarem. In such cases an immediate attack is the result. If he win (as he generally does, if only by reason of his prestige), the state of society remains mualtered. But, if he lose the battle (which generally means losing his life), the conqueror succeeds to his place, and takes as it matter of riglit all his possessions, including his harrem.

It is curions to trace the analogy between these birds and human beings, especially those of the East, whether at the present day or in the ancient times, as depicted in the Old Testament. Substitute human beings for birds, and the country at large for the poultry-yard, and the resemblance is exact. 'There are many petty chieftains; but among them is sure to be one more mighty than the rest, who holds his place by superior force, either of intellect or military power. If challenged by one of the inferior chiefs and is victorious, he retuins his post; while, if he is vanquished, his conqueror takes his place, his property, and his wires. And it is another cnrious point that, whether with men or birds, the members of the harem seem to trouble themselves very little about the change of master.

The Scriptures are full of allusions to the invariable custom that the conqueror takes the possession of the harem belonging to the ranquished. David did so with regard to the women of Saul's household. "I anointed thee king over Israel, and I delivered thee out of the hand of Saul. And I gare thee thy master's house, and thy master's wires into thy bosom " (2 Sam. xii. 7,8 ). So, when Nabal died after his defiance of David, the latter, as a matter of course, took possession of Nabal's wife, together with the rest of his property. Similarly, as had been forctold by the prophet Nathan, when Absalom rebelled against Darid, he publicly took possession of his father's harem as a sign that he had assumed the kingdom.

To those unacquainted with Oriental customs, it seems strange and cruel that when Adonijal asked Bathslieba to persuade her son Solomon to give him Abishag as a wife, he should be at once put to death. But, as explained by those customs, he had for the second time committed hightreason. He was Solomon's elder brother, and had already made an attempt to gain the throne. IIe had fililed, and had been pardoned on condition of future good conduct. But his demand for the hand of Abishag, who had belonged to David's harem, was considered equivalent to a 
second rebellion; and so he and his principal supporters, Joab and Abiathar, met with instant punishment, the former with loss of life, and the latter with deprivation and banishment.

The whole scene is worthy of notice. Bathsheba risits her son in full court, and prefers her request. Solomon, who treated her with the greatest respect as the king's mother, instantly treats Adonijall's demand as an overt act of hightreason. "And King Solomon answered and said unto his mother, And why dost thon ask Abishag the Shunammite for Adonijah? Ask for him the kingdom also, for he is mine elder brother; even for him and for Abiathar the priest, and for Joab the son of Zeruiah."

Now Solomon was a man remarkable for his merey in an mmerciful time and among a ruthless race. He was probably the only Oriental monarch who would not hare secured himself on the throue by putting to death all his brethrena custom which prerails to the present day. Yet he not only spared Adonijah's life, but forgare him after actual rebellion. This second offense was, howerer, unpardonable, the demand of David's wife being tantamount to a claim on David's throne, and therefore he paid the penalty with his life, as being a dangerous man who could not he trusted. Besides these instances, there are many other allusions to the custom scattered through the Scriptures.

The closeness of the parallel between man and beast is most remarkable. In both there is a single despotic ruler who allows no rival; and in both an attempt to gain the affections of one of the harem is considered tantamornt to a challenge for sovereignty, and is treated accordingly.

Sometimes a very curious sort of tyranny is shown where a number of creatures are confined in the same place. Mr. Bennett has some re- marks on this subject in connection with the Mandarin ducks which have already been mentioned under the head of Jealousy.

Spenking of the feeding-time in the aviary, he says: "It is at this time that we can also observe the querulous disposition of these aninuals. The males of one and the same kind of a different species endeavor to grasp all the supplies for themselves, unmindful of the wants of others, and will not even permit their companions to perform their ablutions without molestation, although they may have themselves completed what they required.

"I often observed the Mandarin ducks excite the drakes to attack other males or females of the same species, as well as any other kind of bird (not too powerful) in the ariary, against whom the lady may have taken a dislike from some cause or causes unknown to us. There always appear to be one pair who exercise a tyranny orer the others, not permitting them to wash, eat, or drink, unless at the pleasure of these little aristocrats."

But, of all tyrants, commend me to a spoiled dog, who is even worse than a spoiled child. Obedience is a thing unknown to him. If he is wanted to go out for a walk and prefers to stay at home, he stays at home, and his mastel goes out alone. If he wants to go for a walk, he makes his master go with him, and take the directions which he prefers. Perhaps a better example of tyranny has never been given than Dr. J. Brown's history of the Skye terrier "Duchie." The little animal so completely domineered orer" her mistress that the latter could not eren choose her own dinner, but was obliged to have whatever Duchie preferred, and was once kept out of bed for half a winter's night because Duchie had got, into the middle and dechined to move. 


\title{
CHAPTER XII.
}

\author{
CONSCIENCE.
}

Definition of Conscience.-Its Exercise by the Lower Animals, and Comparison with the Conscience of Man. -Sense of Moral Responsibility in the Dog. - The Butcher's Dog, his Master, and the Old Woman's Money.-Parallel between Dog-servants and Human Serrants._Voluntary Responsibility._-Vic" and the Croquet-hoops._Zeal outrunning Discretion.-The Robber in Custody of "Help."-Dog Cooks and Nursemaids._" Offy" Saving the Servant's Life._Dnty Paramount._."Bree's" Fearful Leap._Mistaken Ideas of Duty._Church-going Dogs._" Apollo's" Leap._- "Boxer's" Notion of Duty._Epigram from "Salmagundi."-Sin and Penitence.-Suicide or Sorrow.-A Dog's Grave.-A Dog's Sense of Wrong-doing.Guardianship._The Cat and the Butcher._- Ungka's" Theft and Restitntion._-Tokla," the Huntingdog, and the Sheep.

To those who have nerer studied the ways of the lower animals, it may seem strange to assert that they, as well as ourselves, possess conscience, $i . e$, a sense of moral responsibility, and a capability of distinguishing between right and wrong. It is necessarily dereloped strongest in those aninals which are placed under the rule of $\mathrm{man}$, and especially in those which, like the dog, belong to his household, and are made his companions. Conscience, in their dealings with man, is their religion, and they often exercise it in a way which wonld put many a human being to shame.

It is this feeling which induces the dog to make itself the guardian of its master's property, and often to defend that property at the risk of its life. For example, if a dog be placed in charge of its master's dinner, the faithful animal will never touch a morsel of food, however hungry it may be. Nay, a dog would rather, as an ordinary rule, die of starvation than eat the food which belonged to his master. We often see field-laborers working at one end of a large field, while their spare clothes and their dinner are at the other end, guarded by a dog. They are quite easy abont the safety of their property, knowing well that the dog will not allow any one to touch either the clothes or the provisions.

A still stronger instance of moral responsibility in a dog has just come before me.

A poor woman, who lived in an unprotected part of Scotland, became unexpectedly possessed of a large sum of money, with which property she was as inuch troubled as "Captain Jack" with the money which he dared not spend, was afraid to show, and could not carry about him for lack of pockets. She wonld have taken it to the bank, but could not leare the house.

At last she asked the adrice of a butcher of her acquaintance, telling him that she was afraid to live alone in the house with such a sum of money.

"Never fear," said the butcher" " I will leare my dog with you, and I'll warrant you that no one will dare to enter your house." So toward evening the dog was brought, and chained up close to the place where the money was kept.

In the middle of the night a robber made his way into the house, and was proceeding to carry off the money, when he was seized by the dog, who held him a prisoner until assistance came. 'The thief was the butcher himself, who thought that he had made sure of the money. He had not considered that his dog was a better moralist than himself, and, instead of betraying a defenseless woman, would even take her part against his own master.

The woman kindly pardoned the intending robber; and I hope that for the future he took a lesson from his own $\log$, and amended the evil of his ways.

A rather notable instance is now before me, where the capacity of conscience, as it is manifested in the lower animals, is rery well shown. There is a retriever belonging to a Scotch lawyer, who was a very conscientious animal in his way; that is to say, as far as his intellect would carry him, he was absolutely conscientions; but, unfortunately, there was a limit beyond which conscience conld not assert itself.

For example, no matter how hungry he might be, the dog might be safely left in a room where the dainties which he best loved were left unguarded: not a morsel of food would he touch. But he did not offer any objection to the cat when she stole the food from the table; neither did he display any scruples in sharing with her the product of her theft. 
Neither was he conscientious enough to submit passively to imprisonment when his master wished to dispense with his company : he had a knack of gnawing cords asunder, forcing shutters and opening doors, which showed to a certainty that the animal was actuated in such matters by reason, and net by instinct.

'Ihis faithful animal was killed suddenly by a railway train. His master writes of him as follows: "He was the most honest animal I ever knew, and I only wish that we could get servants as honest. Upon the whole, I think that he was a much more exemplary character than many men and women whom I have known, and I should be very happy to meet him again in some other sphere. I would rather hunt with him on a planetoid, or a ring of Saturn, than spend $m y$ time in the narrow hearen which some zealots would arrogate to themselves and their small sect, if they conld. He certainly had much more charity than they."

Not only does the dog guard the property which is intrusted to its charge, but it often goes a little further and assumes a charge on its own account.

I was lately staying with a friend in the country, and became on very excellent terms with his little bull-terrier, named "Vic." On the second day after my arrival a croquet match was arranged, and I was asked to change the position of the hoops, so as to suit the latest derelopment of the game. Accordingly, I went to the lawn, followed by Vic, who took no particular notice, but lounged about the lawn with no apparent object.

Presently "my friend joined me. "Do you know," said he, "why Vic is loafing about here?"

"No, except that she prefers the garden to the house."

"Not a bit of it. She has come to see that you do not take away any thing out of the garden; and so I came to warn you not to take a hoop or a peg off the lawn."

It appeared that she always acted in the same manner toward people whom she did not know intimately, although, after a time, she had confidence and let them alone. In point of fact, after two or three days had elapsed, Vic never troubled herself about me.

On one occasion her fidelity took an unpleasant form. Her master had lent his chaise to a friend, who was driring it, and who came to a hill. He dismounted, and was stooping to put on the skid, when Vic flew at him, having an idea in her head that he was going off with the wheel. One of the oddest points in Vic's conduct is that, as if out of a sense of politeness, sle does not make her watch an ostentatious one, but merely keeps in view the object which she is guarding, and the person of whom she is suspicious.

In the cases which I have mentioned, Vic was entirely wrong in her surmises. A remarkable instance, howerer, has reached me, where the dog was right, and acted in a way that would have been creditable to any linman being:

" Of 'Help,' a Newfoundland dog, sereral stories are told, and there was one especially which showed that lis sense of responsibility overcame that of friendship. His master owned a woodyard, from which there had been a constant series of mysterious thefts. At last the dog was put into the yard for the night, in hopes that he might scare away the thief.

"Next morning, Help was found guarding one of the men belonging to the premises, who had a bundle of wood upon him. 'The man was aware that the dog knew him perfectly well, and had presumed on the animal's forbearance. Help, however, assumed so fierce an aspect that even the certainty of detection did not give him conrage to oppose the faithful creature, nor eren to get rid of his compromising load."

Dr. J. Brown relates a similar anecdote of "Rab." He flew at the throat of a man who tried to rob his master, pulled him down, and remained in charge of the fallen man while his master went on his journey. After a while he was seen coming alone to rejoin his master. It appeared that the robber was a neighbor whom the dog knew, and so, giring him a thorough fright, he let him off, after subjecting him to very humiliating treatment.

It is well known that in India the elephant is sometimes taught to take charge of children, especially if they happen to belong to his driver; but the dog appears to be even a more curious nurse than the elephant. The dog Help, however, who took prisoner the midnight robber, was accustomed to act as nurse, and performed the task as well as any elephant could have done, and indeed better than some nursemaids do.

"At times Help could take the place of the nursemaid, and was often intrusted with the entire charge of a little girl, only old enough to crawl on the floor. As long as she amused herself safely, Help looked on with quiet dignity; but whenerer she moved toward the fire, or in any direction that seemed dangerous, he put his great paw upon her, and turned her another way."

One of my friends has written to say that she knows a dog in Berkshire who acts on the same principle as Help, though, on account of his small size, he can not do without human assistance. When the cook puts a saucepan on the fire, she 
sets the dog to watch it, and can go about other business in perfect security, knowing that, if the saucepan should boil over, he will call her. He is also put in charge of the cradle; and if the child should wake up, goes and fetches the mursemaid. In these cases, besides the sense of responsibility, there is much reasoning power, and a capability of understanding human language. And it must be noticed that the dog last mentioned never brings the cook to the cradle, nor the nurse to the saucepan.

A somewhat similar case is related by a lady whom I have known for some years:

"One of my earliest recollections is of a fat, black, curly-haired old dog, called 'Offy.' 'This was an abbreviation of orphan, his mother having died immediately after lis birth, and his father being unknown. Offy was the delight of our hearts, the kindest, gentlest, and most attached of dogrs. At night he always lay at the top of the stairs leading to the nursery, so that no one could enter without his permission.

"Once, when we were at the seaside, my nurse had a rheumatic fever, and was quite helpless. By chance one day she was left alone, propped up with pillows in a large arm-chair near the fire. Suddenly the house resounded with Offy's barks. One maid was out walking with us, and the other was busy getting dinner in the kitchen, when Offy's barks attracted her notice. Running upstairs, she was met by the dog, who ran down to meet her, caught her by the dress, pulled her up the stairs, and there, lying on the floor, with her head and arm on the fender, lay the poor nurse, unable to move. Without the dog, she must have been burned to death."

Here we have a variety of qualities which certainly do not belong to the mortal part of a living being, whether man or beast. First, there is sympathy with suffering. Then there is reason, telling the animal that the fallen woman was in danger, and conld not help herself. Reason also told the dog that he was incapable of helping her himself, and that he must summon some one who had the power. He then had recourse to his own language, which he knew would be understood, and called for help as intelligibly as if he had spoken human words.

Sometimes conscience assumes the form of moral responsibility, the animal being determined, at any risk, to perform the task which is allotted to it. $\Lambda$ gentleman, to whom I am indebted for many original aneclotes abont various animals, has sent me the following account of determination to fulfill a duty :

"' 'Bree,' an English water-spaniel belonging to me, was bred from two London prize dogs of that class.

"A few years ago, his former master" went to" St. Abb's Head for shooting. At the 'Staples Heugh' he winged a duck. The bird, in agony, rolled over the precipice; while poor Bree ran with such impetuosity that he jumped over into the sea, a height exceeding one hundred feet, and fell into some forty feet of water.

"When he caine to the surface, there wats no place near where he conld land, and, seeing the duck rounding the 'West-hare-cars,' he struck out, and, after following it past the 'Skelly,' the 'Ramfands,' the Goose-cruives,' etc., overtook it at the 'Clawfords,' in 'Hare-law-cove Bay. Grasping the dnck in his mouth, he proceeded with it up 'Eel-car-brae,' one of the most difficult passes on St. Abb's Head, and, on reaching his master, laid the bird at his feet."

The distance which the dog swam is somewhere about a mile. 'The gentleman, through whom this anecdote was sent to me, writes as follows: "As to the story of St. Abb's Head, you wonld require to see it before you could appreciate what a dreadful leap the dog had taken." I possess photographs of Bree, his master, and St. Abb's Hcad. The latter word, by the bye, is an abbreviation of Ebba, the remains of whose convent are still to be traced, close to the head itself. "Staples" is a corruption of "steeples," a word derived from some rocks that stand steeplewise in the sea.

The fall must have bcen a tremendons one, and how the dog escaped instant death is more than I can imagine. The shock must have been a very severe one, and the animal would have been quite justified in coming ashore at once. But he knew that his rluty was to catch the duck, and he did so. 'That he did receive a very great shock is evident from the fact that, although a retrierer, and by natmre a good water-dog, he has since this adrenture contracted such a horror of the sea that he can scarcely be induced to enter it.

Somctimes the dog takes up a wrong idea of duty, but persereres in it, notwithstanding all obstacles. In the two following instances the dog considcred that his duty lay in accompanying his master, and set himself to discover some plan of orercoming obstacles:

"A friend of ours, a clergyman in one of those rural Welsh villages whose name we find some difficulty in writing, and still more in pronouncing, had a spaniel, sent from a friend in England to the rectory of $\mathrm{C}$ - I I forget now the correct spelling, but no matter.

"Soon after" his arrival, the dog proved himself a most determined church-goer. 'The first attempt took the fimily quite by surprise. Ther 
knew not he had accompanied them, until they had taken their scats; so they very wisely pushed him underneath, where he remained during the service, one of the quietest members of his master's congregation. The next Sunday, when the church bells commenced, the dog was shut in the library; but, soon after the service had begun, he jumped through the window, pushed open the church door, walked with all proper demureness to his own pew, and resumed his former position under the seat, where he was again allowed to remain. On the third Sunday, the dog's movements were more vigilantly watched. Directly the bélls began, he started off full trot to the church, once more occupied his old corner, defied alike the threats and persuasions of the servant to remove him, and, on the arrival of the family, welcomed them triumphantly.

"One more last attempt was made on the succeeding Sunday to keep him away, which was only a partial success. Early in the morning he was shut in a shed, from which he could find no egress; but, directly the bells began, he struck up a loud howling accompaniment, which he continned during the whole of church-time, and, as the church was close to the rectory, he could be lieard at intervals during the service, of course disturbing the risible powers of the junior members of the congregation, so that nothing remained but to send him back to his former master in England."

The dog in question onght to have learned by heart an epigram in a curions and very scarce quarto book called "Sulmagundi." It was published in 1791, and I have a copy, which was presented by the anthor to my grandfather. It is, in its way, as interesting as are Gilray's political caricatures, comprising, as it does, the famous "Wilkes and Liberty" times, and abounding with witty little jeux d'esprit in Latin and English. Here is the epigram which has been mentioned :

ON A FAVORITE DOG WHO REGULARLY ACCOMPANIED HIS MISTRESS TO CHURCH.

"Tis held by folks of deep research, IIe's a irood dog who goes to church ; As good I hold him every whit, Who stays at home and turns the spit: For though good dogs to church may go, Yet going there don't make them so."

A somewhat similar instance occurred to $m y-$ self. I was making some arrangements in the church, and had left my dogs outside, thinking that they wonld amuse themselves by swimming in a neighboring pond, as they were accustomed to do. I had, however, not been in the bnilding for many minutes when a scratching, scrambling sound was heard, followed by a heary thump, and up came iny bull-dog "A pollo," looking delighted to see me.

I put lim ont at the door, but could not imagine how he had made his entrance. Presently there was another scratching, and I saw Apollo's head at a little window which had been left open for ventilation. He contrived, in some curious manner, to hold on by his fore paws unltil he scrambled his lind legs upon the sill, and then forced himself through an aperture so small that he conld not jump, but liad to let himself fill. The window is at a considerable height from the ground; and, as a rather wide trench runs around the building, Apollo had to make a tremendons leap to reach the window-sill. He had evidently fililed several times, the scratches on the old wall showing where he had slid down. He always was a fine jumper, but this window must have tested his leaping powers to the utmost.

Sometimes we see in mankind an instance of good-hearted blundering. wrong-headed honesty; and much the same mixture of characteristics is to be found in the dog.

There was a brilliant black-and-tan terrier, named "Boxer," belonging to a Mr. B-, who was then in India, and about to proceed on the welcome journey home. Boxer had one prevailing idea in his doggish mind, namely, that he had perpetually to take care of some one or something. He watched his master's property with the utmost fidelity. Once, after the return of the family to Scotland, a comple of Irish beggars came by, and were giren a good meal, the empty dish to be left ontside the house. When they had finislied, the woman, seeing that the cook was not in the kitclien, slipped in and stole a loaf of bread. She had not calculated on Boxer, who was ont in a moment, canght the woinan by the bare ankle, and there held her until his master came himself to take charge of the thief.

Had the dog restricted himself to such gnardianship, he wonld have been a most excellent gnardian; but, unfortunately, he was possessed witl a rooted idea that every one who approached his mistress meant to hurt her, and must therefore be assanlted. When she was ill, and lying on a couch, he used to sit by her side, and was so careful in lis watch that he would not allow even her husband to approach without seizing lim. He did not hurt his master, though he bit his ankle a hundred times, by way of reminding lim tlat his mistress was not to be disturbed.

In one way he was really useful, especially during the residence of the family in India. During her illness, his mistress had a rery great antipathy to centipedes, cockroaches, and other 
crecping things, of which there is ample store in that country. Boxer somehow found out that they were obnoxious to his mistress, and used to keep a sharp lookout for them if they approached her. Sometimes, if he were not at hand, and he heard a scream, he would dash off to his mistress, look about for the cause of her annoyance, and straightway demolish it.

In his anxiety to do his duty to his mistress, Boxer sometimes allowed his zeal to ontrun his discretion.

Once, during the voyage, the ship was becalmed in the tropics, so that the man at the wheel had a sinecure. Mrs. B w was lying in the cabin at the time. The man, seeing a needle lying just outside the door of the cabin, went and picked it «p, and was instantly pimed by Boxer, who chose to think that he was stealing the property of his mistress. He did not hurt the man, but frightened him so much that he hallooed loud enough to alarm all the inmates of the ship. Among others, Mrs. B__ ran ont to see what was the matter, and advised the man to put the needle down again. 'This he did, when Boxer at once released him.

He behaved in a somewhat similar manner when the ship arrived in the Core of Cork, though in this instance with more show of right. The stores of biscuit had been got up on the maindeck, for the purpose of ridding them of the cockroaches, weevils, and other umpleasant creatures that are apt to infest provisions. A number of Irishmen came on board with milk, eggs, etc., for sale, and one of them, thinking no harm, began to eat a biscuit. Boxer, howerer, considered himself the guardian of the ship's stores, flew at the man, and drove him away.

When lome was reached, he took, in his wrongheaded way, a violent antipathy to the clergyman. Perhaps he objected to a black dress, after being accustomed to the light costumes of India. At all erents, he could not endure the gentleman, and always seemed to know instinctirely whenerer he was approaching the house. On these occasions it was necessary to shut him up; and even then he used to tear and scratch at the door so furiously that he greatly damaged it. The oddest part of the proceeding was that as soon as the gentleman was in the room with his master and mistress Boxer did not tronble himself about him.

'This queer', faithful, blundering dog lived for' nearly twenty years in the family.

$\Lambda$ very common form of conscience among the lower animals is that which nay be defined as a recognition of haring lone wrong, and an acknowledgment that punishment is deserved.
It is exactly the same feeling which indnced Adam to hide himself after he had fallen into sin. Animals have in their way rery decided ideas as to right and wrong; and when they have conmitted an act which they know will offend their master, they display as keen a conscience as could be exhibited by any human being self-convicted of a sin; and, in many cases, the offense is acknowledged, and the creature remains miserable until pardon has been granted. 'This re call in ourselves penitence.

Two examples of this phase of conscience are here giren. As to the first, I was in doubt whether to place it under the head of Reasoning, Language, or Love of Owner. But, as it illustrates the power of conscience in the lower animals, I have placed it inder the present head, without, however, removing the passages relating to the other qualities :

"Reasoning powers are certainly exercised by dogs; how would they otherwise know when Sunday came around? Our large dog, 'Bran,' al cross between a retriever and a deerhound, never thinks of following us to church, though he regularly comes in on Sunday afternoon, in expectation of the walk which he knows his young masters take between the services; and on weekdays he will eren run up-stairs if he hears us moring about the bedrooms, which he in some way comnects with walking out. He looks so intelligent that it is difficult to believe he does not understand conversations, and we talk to him often as if he were a human being. He is very good-tempered, and particularly so with cats and children. When we were at Worthing, two years ago, a large white cat belonging to the house constantly shared his bed; and on more than one occasion the cat, dog, and the little grandchild of our landlady were found curled up together.

"Whenerer he did wrong as a young dog, we found the greatest punishment was to take no notice of him, and refuse his offered paw. On one occasion, I remember, he ran off, and was missing all day. When he came back, he was shut up in his sleeping-place, after we had shaken our heads at him and turned away. Although he must have been rery hungry, he would not touch his food, but sat close to the door, whining and crying, till we made it np with him by telling him he was forgiren, and taking his offered paw, when he ate his supper and went quietly to bed. Ilis lore for uts is nubounded, and he ahmost orelwhelms us sometimes by his affcctionate embraces, especially if we have been away, when lee almost talks in his joy at seeing us again.' 
A lady has sent me a short account of the behavior of another dog, which clearly shows that the animal possesses the attribute of conscience. The little animal has been taught many tricks, among which is the accomplishment of shaking hands. This he will scldom condescend to do without much coaxing; but if he has done any thing wrong, he comes up, looking very much ashamed of himself, and voluntarily offers his paw.

I may here refer to the dog "Help," who went sheep-killing while his master thought that he was chained up at home. It was a clear case of conscience, though not accompanied by penitence. He knew that he was acting wrongly, and that his master would be offended, and therefore endeavored to avoid punishment by destroying the evidcnce of his crime.

How painfully kcen can be the sense of conscience in the dog is shown by the following account, which is written by a brother clergyman well known in the literary world:

"A Newfoundland dog of great age, bnt still the gentle, good-tempered friend of his master's children, lay one morning sound asleep. One of his playmates, wishing that he should accompany their walk, gave him a kick. The poor dog, suddenly awakened, seized sharply the little girl's leg, but without really hurting her. The nurse therenpon scolded him, pretended to beat lim with a pocket-handkerchief, and, when he wanted to go with them, shut the door in his face.

"One of the men soon afterward fornd him lying with his head in a ditch, dragged him out, and brought him to the stables, where he lay, refusing to eat or drink. Ere long he was again found at the same ditch, dead. Whether, in remorse and despair of forgiveness, he had snecessfully repeated an attempt at suicide, or whether he had lain down there to die of a broken heart, I do not know."

One or the other was evidently the case, and, whether it were suicide or sorrow, conscience was the real cause of death.

The same writer proceeds to say: "You also asked for the epitaph on our poor little friend's grave. It is as follows:

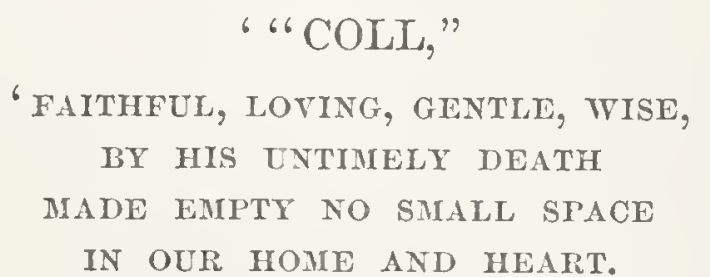

'Alas! too soon, dear loving friend, Onr close companionship doth end; Tet sense of Right, heart true and fond, Must have, methinks, some glad BEIOND.'
"Poor H. ! it was her first great grief, and yet lives. A cousin spoke lightly of the epitaph as she stood by the grave the other day in her garden.

"'Please come away, G.,' said H., ' and don't let us speak about it. Something has been left out in your composition; you can not understand." "

With regard to the supposition that the former of these dogs committed suicide, it is not so groundless as might be supposed. Dogs certainly know that water will drown other beings, or they would not take the trouble of rescuing them; and it is therefore but natural to infer that they are aware that the same element will drown themselves. There is more than one instance known of a dog deliberately drowning itself; and the instance which has just been narrated looks very much as if the same course had been adopted.

The following little story is one of Lady E.'s anecdotes, and shows how not only dogs, but cats, can possess a sense of moral responsibility:

"I trust the following anecdote of my cat 'Rosy' may be found interesting.

"You know that she was given to me when quite a kitten, and she is now nearly fourteen years old. She has always had a great aversion to dogs, and, no matter what their size might be, she would drive them away if they came on our prenises.

"Whenever the servants left the kitchen, she would sit-near the door, and, if a stranger approached, growled like a dog. One day the cook had left the cat alone, and the butcher's boy came for orders as usual. Receiving no reply, he opened the door and walked inside. Perceiving him to be a stranger, Rosy, to his surprise, flew at him, and held him tightly till the cook returned. Instead of being angry at the attack, the lad admired her bravery, said she was as good as a house-dog, and often rewarded her with meat from his shop."

In Bennett's "Wanderings in New South Wales," the siamese ape "Ungka" is mentioned as possessing the sense of moral responsibility, though the mode in which it was manifested was rather of the ludicrous than the lofty kind:

"One instance of a very close approximation to, if it may not be considered absolutely an exercise of the reasoning faculty, occurred in this animal.

"Once or twice I lectured him for taking away my soap continmally from the washing-place, which he would remove for his amusement from that place, and leave it about the cabin. One 
morning I was writing, the ape being present in the cabin, when, casting my eyes toward him, I saw the little fellow taking the soap. I watched him, withont his perceiving that I did so; and he would occasionally cast a furtive glance toward the place where I sat. I pretended to write; he, seeing me busily occupied, took the soap, and moved away with it in his paws. When he had walked half the length of the cabin, I spoke quietly, without frightening him. The instant he found I saw him lie walked back again, and deposited the soap nearly in the same place from which he had taken it.

"There was certainly something more than instinct in that action. He evidently betrayed a consciousness of having done wrong, both by his first and last actions; and what is reason, if that is not an exercise of it?"

I know a little child, not two years old, whose favorite amusement is to get at a box full of Windsor soap, and disperse the cakes all over the room, in all sorts of places. She is not allowed to do so withont permission; and more than once, when she has been detected in doing so, she has acted exactly as Ungka did, i.e., replaced the soap, and tried to look as if she had not tonched it. In both cases the process of reasoning is identical; and so is the sense of conscience, or moral responsibility.

A curious example of the power of conscience is related by Mr. Mansfield Parkyns, in his wellknown work on Abyssinia. He had a semitamed hunting-dog (one of the wild animals of the country), and was much interested in the habits of the animal, which he named "Tokla."

"Once I remember being attracted into the yard by a bustling noise as of animals running about, intermixed with my pet's shrill, squeaking voice. On going out, nothing was apparent but a sheep lately bought for dinner, which, howerer, was running about with every appearance of nerrousness. There was Tokla, whose voice I had just heard nttering notes of unusual excitement, lying quietly in a corner, shamming sleep, but peeping at me from a corner of one of his little wicked black eyes.

"I said nothing, bnt concealed myself in a shed, through the branches that formed the sides of which I could observe all that passed. For a short time the little brute lay motionless in the same position as I had left him. After a while, howerer, he got up stealthily, stretching himself as if just awake, but at the same time taking a furtire glance to see that all was quiet. Having satisfied himself on this point, he made a rush at the poor sheep, with his ears back, and squeaking horribly. The sheep ran away when it conld, only standing and butting at its little opponent when driven into a corner, and eridently in a desperate fright.

"Tokla seemed to heed little whether hoof or horns met his advances, but kept on, now rushing furiously in, now dodging for a more favorable opening, incessantly for half an hour. I doubt not, though scarcely six pounds' weight, he would have ended by walking into the mutton of his adversary had I not felt compassion for the poor sheep's sufferings, and disturbed my little friend in his pursuit. Indeed, I could not have allowed him to indulge his sporting propensities so long as he did except as a study of his natural ideas, manners, and customs."

Here is a distinct case of conscience, and of cheating in order to conceal his delinquency. He was perfectly aware that he was doing wrong in attacking the sheep, and so feigned to be sleeping when his master came on the scene. This is the more curious, because Tokla was not one of the domestic dogs, but a predacious animal which had only been recently and partially tamed.

Almost every one who has possessed pet animals must have noticed how often they exhibit remorse, $i . e$, a keen sense of having done wrong, their conscience having convicted them of their misconduct, and their whole demeanor showing that they are sensible of their fault.

Here is an example: A Mr. B _ had a magnificent staghound, named "Grynne." The dog had one fault : he was not fond of children, and therefore was given away, as unsuitable for his owner's house.

His new master lived in Sutherlandshire, and sent the dog to one of his farthest farms, where he was taken in charge by the shepherd's wife. One morning, after the woman had made the porridge for breakfast, she went out of the house, and on returning met the dog, who had eridently been eating the porridge. With an expression of anger she struck him on the head, whereupon Gwynne left the place, and was never seen again, though advertisements and liberal offers of reward were issued.

This, however, is not all. Several times previonsly he had been given away, and had always made his way back to his old master ; but this time he did not do so, evidently because he felt himself rightfully in disgrace for bad conduct, and he did not dare to show himself in his master's presence. 


\section{CHAPTER XIII.}

\section{SYMPATHY AND FRIENDSHIP.}

Love and its Varions Phases of Development._Sympathy between Auimals of the Same Species.-Dr.J. Browu's Story of "Nipper" and the Destitute Pointer.-Protection of the Weak._-"Pizarro" aud the Terrier._"Mungo" and his Big Frieud.-The Ludicrons Side of Sympathy._Church Bells and their Effects.-Cats and their Comrades._Division of Labor. -Sympathy in the Weasel._Sympathy betweeu Auimals of Difierent Species._Several Auecdotes of Dogs and Cats._The Dog and the Persecuted Cock.Dog Feediug Kids._Cat-sympathy._The Graudmother, the Daughter, aud the Dead Graudchild. - A Generons Redbreast._Animals Sympathizing with Mau._Story of "Nelly" and her Mistress.-Nelly's Death aud Last Request._"Prettiua's" Sympathy with a Sufferer._"Flo," the Family Cousoler._Friendship Defined._"Piucher" aud the Quarrelsome Sheep-dog._Friendship between Cats._The Story of "Dick" and "Kate."-Kittens and Dog.-Friendship between Cows and a Sheep; Cats and Horses.-Frieudship between a IIorse, a Cat, aud a Lame Chicken.-Frieudship between a Cat and Ducks.-Friendship between a Dog aud Ducks; Java Sparrows aud Doves; a Moukey aud a Heu.

We are now approaching the loftiest characteristic which adorns humanity-namely, Loveand are about to inquire how far it is shared by the lower animals. It has many phases of derelopment, the first of which is sympathy, $i . e .$, the capacity of feeling for the sufferings of another. I shall show that many and perhaps all living creatures possess the capacity of sympathy, and that in numerous cases it is not restricted to their own species, but is extended to those beings which appear to have very little in common with each other.

Usually, howerer, sympathy is exhibited between animals of the same species, and is often seen in the dog. Such, for example, is the wellknown instance where one dog was seen supporting the broken leg of another; also the fact that a dog which has been cured of some injury will take a fellow-sufferer to his benefactor-an example of which I knew personally. I need hardly observe that such sympathy could not be carried out unless the animals possessed a language snfficiently defined to transmit ideas from one to the other.

I will begin with a few instances of sympathy between animals of the same species, and place at their head Dr. J. Brown's graphic account of his dog "Nipper:"

"Many years ago I got a proof of the unseen and therefore unhelped miseries of the homeiess dog. I was walking down 1)uke Street, when I felt myself gently nipped in the leg. I turned, and there was a ragged little terrier cronching and abasing himself ntterly, as if asking pardon for whist lie had done. He then stood up on end, and begged as only these coaxing little ruffians can.

"Being in a hurry, I curtly praised his performance with 'Good dog!' clapped his dirty sides, and, turning around, made down the hill; when presently the same nip, perhaps a little nippier-the same scene, only more intense-the same begging and urgent motioning of his short, sliaggy paws. 'There's meaning in this,' said I to myself, and looked at him keenly and differently. He seemed to twig at once, and, with a shrill cry, was off much fister than I could follow. He stopped every now and then to see that I followed, and, by way of putting off the time and urging me, got up on the aforesaid portion of his body, and when I came up was off again.

"This continued till, after going throngh sundry streets and by-lanes, we came to a gate, under which my short-legged friend disappeared. ()f cour'se I couldn't follow him. 'I'his astonished him greatly. He came out to me, and as much as said, 'Why don't you come in?' I tried to open it, but in vain. My friend ranished, and was silent. I was learing in despair and disgust, when I heard his muffled, ecstatic yelp fun off" around the end of the wall; and there he was, wild with excitement. I followed, and came to a place where, with a somewhat burglarious ingennity, I got myself squeezed into a deserted coach-yard, lying all rude and waste.

"My peremptory small friend went under a shed, and disappeared in a twinkling throngh the window of an old coach body, which liad long ago parted from its wheels and becoms sedentary. I remember the arms of the Fite 
family were on its panel; and I dare say this chariot, with its $\mathrm{C}$ springs, had fignred in 1822 at the King's visit, when all scotland was somewhat Fifeish. I looked in, and there was a pointer bitch, with a litter of five pups; the mother like a ghost, and wild witl maternity and hunger ; her raging, yelling brood tearing away at her dry dugs.

"I never saw a more affecting or more miserable scene than that family inside the coach. 'The poor bewildered mother, I found, had been lost by some sportsman returning south, and must have slunk away there into that deserted place when her pangs (for she has her pangs as well as a dnchess) came; and there, in that forlorn retreat, had she been with them, rushing ont to grab any chance garbage, running back fiercely to them-this going on day after day, night after night. What the relief was when we got her well fed and cared for-and her children, filled and silent, all cuddling about her asleep, and she asleep too-awaking up to assure herself that this was all true, and that there they were, all the five, each as plump as a plum-

\section{"All too happy in the treasure \\ Of her own exceeding pleasure ;"}

what this is in kind, and all the greater in amount as many outnumber one, may be the relief, the happiness, the charity experienced and exercised in a homely, well-regulated Dog Home.

"Nipper-for he was a waif-I took home that night, and gave him his name. He lived a merry life with me-showed much pluck and zeal in the killing of rats, and incontinently slew a cat which had-unnatural brute-unlike his friend-deserted her kittens, and was howling offensively inside his kemnel. He died, aged sixteen, lie:lthy, lean, and happy to the last. As for Perdita and her pups, they brought large prices, the late Andrew Buchanan, of Coltbridge, an excellent authority and man-the honestest ' dog-man' I ever knew-having discorered that their blood and her culture were of the best.

"I have subscribed to the London "Home" erer since I knew of it. and will be glad to do as much more for one of our own, as Edinburgh is nearer and dearer than the city of millions of dogs and men. And let us rememher that our own dogs are in danger of being infected by all the dog-diseases, from the tragic rabies down to the mange and bad manners, by these pariali dogs ; for you know among dogs there is in practical operation that absolnte equality and fraternity which lias only been as yet talked of and shot at ly and for ns."

In this charmingly told anecdote, we see not only sympathy, but self-denial, reasoning, and a power of communicating ideas to a humin being. Being a waif and a strily himself, without a master, and dependent npon chance for food, the little animal took compassion on his suffering companion, and went out to beg from man the assistance which he was not able to render himself. But that assistance was not meant for himself, howerer mucl he needed it, but for his companion who needed it more. Donbtless his instinct, and not his reason, tanght liim to selcct the person to whom he applied; for it is not every man who will allow himself to be nipped in the leg without repaying the bite, howerer gentle, with a kick or a blow. Animals, like chiluren, always know their friends.

See, for example, when he forgot to calculate the difference of size between his newly found friend and himself. Finding that the man conld not crawl under the gate like himself, the tog calculated the dimensions of the man, and pointed out to him an aperture through which he could make his way.

A lady writes to me to say that a friend of hers has two dogs - one a Newfoundland, and the other a small black-and-tan terrier. 'They are both good water-dogs, and are now in the habit of swimming about together. But, on the first occasion after their introduction to each other, when the terrier jumped into the water, the Newfoundland dog sprang in after him and put him on the bank, evidently thinking that he had fallen accidentally into the water and might be drowned.

The following story is sent by another lady:

"We had a noble blood-hound, 'Pizarro,' sent us from Manilla; although his kind are supposed to be more or less savage, he was most gentle when well treated. When on board ship, he became much attached to a small terrier, which no one dared to molest in his presence. 'The sailors msed to take the little terrier in the boat with them, leave Pizarro on hoard the ship, and commence teasing his little friend-a proceeding which rendered the blood-hound most irritable. Ile afterward extended his protecting power to one of those ornamental but nseless Danish dogs, which we had at that time, and who always rushed to his kennel for protection if threatened with punishment, and then no one dared interfere."

Several anecdotes, of a character somewhat similar to the following, are tolerable well known. I ain glad, therefore, to present iny readers with a story which possesses the double advalntage of being both origrinal and authenticated: 
"In a little village in Wiltshire there lived a small black terrier, called 'Mungo,' and a large yard-dog, the two being on the most amicable terms. One night the terrier paid a neighboring farm-house a visit, in order to offer his respects to another little terrier, whom he much admired. But, alas for his gallant intentions! a large rough watch-dog, not tolerating rivals, set on him saragely, and poor Mungo returned home in a sorry plight-bleeding, torn, limping, and scarcely able to crawl.

"He lay down by his faithful friend, and told of lits piteous wooing. Fondly and gently the big dog listened, and licked his friend's wounds, wlio for many a day lay sorely bruised, and never attempted to leave home. Some time afterward, on a fine moonlight night, some laborers, who were returning home across some fields, met the two friends trotting gayly along. Next morning the farmer found his savage watch-dog stretched stiff and stark on the straw in lis yard."

What a combination of qualities do we not find in the conduct of these two dogs. They must liave possessed a language snfficiently definite for the one to tell the other what had befallen him, and to designate the offender. 'They then must have arranged that the big dog was to arenge the injuries inflicted on his little firiend as soon as the latter was well enough to show lim the way. There was memory in both dogs, enabling them to postpone the execution of their design until the injured dog had recorered; and there was sympathy for suffering in the large dog, and desire for revenge in tlie little one. 'The two-dogs in question belonged to a clergyman, who told the story to my correspondent.

There are instances among mankind where eren the best of feelings present a ludicrous side, and animals are not exempt from this rule. In the following example the sympathy was very well meant, though the mode of showing it was exceedingly ludicrous :

"I have said that my dog 'Tion,' a cross between the setter and the sheep-dog, always sets up a piteous howling when the neighboring churcl bells begin calling the villagers to morning service at eleven. At the first slow tolling he takes no notice of the bell, but as they ring the changes he becomes uneasy and wanders about; and when the chimes begir, lie no longer contains his feelings, but howls with all his might. He is by no means a howling dog, and bears all the other ills of life with patience, or, at most, indulges in a whine.
"Now my mother's dog 'Snap, a pure Skye terrier, is, as a rule, supremely indifferent to bells, though she will bark by the hour together at a treed squirrel or at some distant or eren imaginary sound. No sooner, howerer, does she, when on a visit to my cottage, lear Lion's cry of distress and remonstrance, than slie joins the chorus, and the two dogs will sit on their hamnches, with nose in air, and lowl there until I call them in, or until the bells abate their noise. The one $\operatorname{dog}$ affords a good picture of sorrow, and the other of sympathy."

Perhaps Snap thought that it was only good manners to show that she felt for Lion's sufferings, though she did not share them herself, and so slie joined him in lis lamentations.

It may be, howerer, that Lion had more cause for complaint than we might fancy. There are many dogs to whom certain sounds are not only obnoxious, but actually injurious. This is well corroborated by a curious anecdote communicated to me by the late J. Hatton, M.D.:

"With regard to the effects of sound upon animals, I remember, when a cliild, my brother going into the country, on a Sunday afternoon, to see a friend, who gave him a young pup, about ten weeks old. At that time we lived in the precincts of the Cathedral. The ringers were accustomed to practice every Sunday erening at eight o clock. No soonel did they begin than the dog began to run round and round the room at a furious rate, and finally rushed under the sofa, where the poor animal almost immediately died in convulsions."

Cats are often kind to each other, sympatlizing under difficulties, and helping their friends who need assistance. One of my friends is a great admirer of cats and their disposition, and has noted many of their ways. One of her cats was rather a weak animal, and was unable to carry her littens about after the manner of cats. So, when she wished to carry her kittens fiom one place to another, she was accustomed to impress a stronger cat into her service, she walking by the side of her friend in order to act as guide.

Another of the cats, when oppressed with the cares of a family, did exactly what a liuman mother does when she can afford it. She employed a nursemaid, $i$. e., sle brought a halfgrown kitten, and placed it in charge of lier young while she went for a ramble.

In Hardwicke's Science Gossip, which is really a treasure-house of information for those who know how to use it, are many anecdotes of 
sympathy between animals. One of these anecdotes shows reason as well as sympathy in the common weasel.

A clergyman was driving along the road near Basingstoke, when his horse trod on a wcasel, which could not get out of the way in time. The little animal was paralyzed, its spine seeming to be broken, so that it could not move its hind legs. Presently another weasel came out of the roadside, went up to the injured animal, and, after carefilly inspecting the invalid, picked it up and carried it to the side of the road, where it would not be endangered by traffic.

Another case of sympathy between creatures of the same species is given in the same journal. A female wood-pigeon was sitting on her eggs, and her mate was close at hand. A heavy shower of rain came suddenly on, whereupon the male bird took lip a position above his mate (who could not leave her eggs), and with his spread wings formed a shelter from the rain.

We will now pass to sympathy between animals of different species. The hereditary enmity between cat and dog is proverbial; and yet, when in good hands, they are sure to become very loving friends, and even to show considerable sympathy with each other. Here is a case in which the animals had but the slightest passing acquaintance with each other. 'The anecdote which immediately follows is communicated by the same lady:

"Compassion was shown in the following case. A poor little cat was lying very ill by the kitchen fire; another cat came inquiringly up. A Scotch terrier (helonging to the honse in which we were then lodging, and therefore a comparative stranger to the invalid) immediately jumped off a chair, and silently but firmly turned it back, as if to say, 'Yon must not disturb her.' He also tmrned back in the same manner our own large dog."

"Many years ago my mother had a cat and 1 dog; and when the cat had kittens, the dog, a terrier, would take charge of them for an homr at a time, and no one dared touch them. Although at other times he was gentle, he then snarled at all comers. Directly the mother reappeared, 'Fly' walked off and resigned his charge."

The forr following anecdotes all relate to srmpatlyy between cats and dogs, and have been sent by different correspondents :

"One day a large black cat entered the garden in a most deplorable condition, her tail nearly cut in two by a tin kettle which had been tied to it. 'The kettle was taken off, and the poor creature brought into the house and fed. Our little dog 'I'rotty' was greatly delighted to have another friend; but 'Blackie,' as we called the cat, would not allow him to go near her, scratching and spitting if he approached. All the time her tail seemed very painful, but at the end of three or four days Trotty somelow managed to bite off' the end of it. 'This eased the poor creature's pains, and from that time they were loving friends."

Trotty's reasoning was as correct in this case as if he had been the subject of transmigration, and had formerly inhabited the body of a hospital surgeon.

"When our little dog Trotty was quite young, we had a kitten, 'Mittie' by name. She was a gentle, loving creature, who evidently disliked being pulled about and teased by Trotty, but only resented it in the most gentle way. The result of this teasing was that poor little Mittie did not grow, and at ten months old she was a dwarf.

"She was then accidentally scalded, and so badly that for some weeks she lay on a pillow, and had her sores regularly dressed with oil. All this while Trotty was apparently troubled, and when the sores were partially healed he gently licked them, and so aided in her recovery. From that time he never teased her, and they lived together for a year, Mittie growing into a fine cat.

"At the end of this time I fancied that Trotty was again at liis tricks, but on closely watching them I found that Mittie held up her head in order that Trotty might lick her neck, on whici we found a small lump. This went on for some time, Mittie touching 'Trotty with her paw when she wished to be licked, and again when she wished him to desist. The lump proved malignant, and dear little Mittic died. Trotty was restless for weeks, and would not eat as usual."

"There was a ferocious bull-dog kept as a guardian of the premises. He was so fierce that on one occasion he tried to bite his mistress because she rentured too ncar his kennel. Once, however, he shorred that he was not deficient in kindly feelings, and that they might have been developed by proper management.

"One day a little kitten got out of a window three stories high, and fell on the stone paving of the yard near the dog's kennel. It was so hurt and crushed that eren its mother would not go near it. 'The dog, however, picked it up carcfully, took it into his kemnel, licked it clean, and nursed it carefully till the poor little thing died."

“' 'Bandy,' our turnspit dog, was an inmate 
of the house before Miss 'Chinchilla' Puss came to reside in it ten montlis ago. She was rery wild and friglitened when she came, dogs being her natmral abhorrence; but by constant association at the dimner-table, rom the fireplace, and even in the ladies' rooms, they became good friends; and their love was cemented on the occasion of poor Bandy having had a fit and being unable to move for some hours. Miss Chinchilla came frequently to inquire for him, and greeted him with a lisiss - literally they touched lips and noses.

"T'ime passed on, and Chinchilla arrived at the dignified state of married life, and a month ago she had her first kitten. On the occasion, Bandy's anxious solicitations were constant and gentle, nor could his curiosity be satisfied on hearing the kitten's wee voice till he had seen and smelt kitty. The sight of such a warm small lump of life excited an interest which was far greater than curiosity, and whenever Chinchilla left her kitten for any time, he took upon himself the office of guardian and murse, for he licked and watched it as if it had been one of his own offspring. The other evening, while the mother was away, he eren got into the cat's basket, and curled himself up in it, as she does, while the kitten lay upon him and under his paw exactly as it does with its mother. Now at a month old Kitty goes up to him and 'shows fight' (as children say when they want to have a stand-up game), while the mother looks on, waiting to share in the fum.

"I am hoping to see, when Kitty grows up, that she will have extinguished the natural antipathy of her race to the dog tribe; if so, I think it will be a beautiful proof of cultivation and domestication obliterating the prejudices of instinct and hereditary habits. Since it is the affection and instinct that form the life of all existences, I believe and hope we are cultivating the immortal principle in our domestic animals by subduing the more animal natmre, and educating their affections and intelligences, and so dereloping a higher race of dogs and cats, or horses, or any other" pet.

"I should like to know if you think that in the next stage of existence our animals will know us individually as they do now in a measure by smell and scent and roice. I am anxions to see your work on the proofs of immortality in animals. I do so hope that, when I pass beyond the reil, I shall know and be recognized by a dear old pet dog, 'Beppo,' a most deroted animal, who lived and died with us."

A gentleman living in Edinburgh has just sent me this remarkable anecdote of sympathy in a dog, showing how wide can be a dog's sympathies, and how cleverly he can carry them into effect:

"I once gare a spaniel, called 'Jack,' to a firmer friend in the neiglnborhood of the city. Jack's kennel was placed in the farm-yard, where the poultry were daily fed. Among them happened to be a poor, unfortunate, unpopular cock, which was not allowed to have a share of what was going, but was punished severely whenerer he made an attempt to get any food.

"Jack somehow observed this, and, feeling sympatly for the poor bird, was seen daily to leave some of his food, to carry the "bicker" which contained it into lis kemnel, and wait there until all the poultry were gone. He would then take his bicker ontside, put it down where the cock could get it, and stand on watch all the time in order to protect liim. Sometimes he would leave the bicker inside the kemnel, and, if the bird were near at hand, he wonld go round about him until he got him into the liennel, so that he might take his food without being disturberl.

"I regret to say that Jack is now dead; but he was a dog of more than ordinary canine parts for he exhibited a sagacity and sympatlyy toward that sadly tormented bird which showed that he was an animal of a rare stamp, and far above lis fellows."

I hope that the reader will appreciate the character of this dog as it deserres, and see how he displayed virtues of which any human being might be proud. There is compassion for sufferings unjustly inflicted upon a fellowbeing, and a determination to redress them. Then there is self-denial in depriving himself of his food, generosity in giving it alray, and high reasoning power as exemplified by the rarious means employed in managing that the poor persecuted bird should have its food in peace, undisturbed by its heartless fellows.

The end of this strange friendship was very remarkable.

The ill-usage of the other birds still continued, and at last the cock was accustomed regularly to take refuge in the dog's kemel. Probably from the perpetual bullying which he endured, he fell ill, and one morning was found dead in the kemnel, lying closely pressed to his only friend.

Giving food, indeed, seems to be a farorite way by which animals of different species express their sympathies with each other. Tlie following little history is given in the Zoologist, page 9649 : 
"Last year, when the troops left this station to proceed to the frontier war, a goat belonging to an officer had two young lidis the very morning the force marched. The cruel native servants, who have less feeling than any animal, even a tiger, took with them the poor motler and left the two kids behind, because to carry them would have entailed a little trouble - a thing most deroutly ablorred by this class of menials.

"The little kids made a terrible blenting noise at being left all alone; and a pariah dog, who was employed as a wet-nurse in the opposite compound for two English puppies, came over the road and took the lielpless little lids in her month, and conveyed them to the box where her two puppies were. After this she regularly suckled them, and brought them up with the other two of her adopted fimily. It was a curious siglit, the old lady suckling two pupjies and two kids. She lay down to the former, but had to stand np for the latter, for they used to run at her in the usual rehement way lambs and kids do at their mothers, which often gave the dog great pain; but notwithstanding this she was never known to bite at them.

"These two kids grew up and followed the dog about, along with the puppies, all day, until the kids became as big as the old dog helself; she nursed them for about three months, when she had a family of her own, and left off taking any notice of them further than by a good-humored wag of the tail or an occasional lick of their faces. These kids grew up to be big goats, and contimued playing with the dogs, their foster brother and sister. The old dog had been in the first place deprived of her own offspring, and the two puppies had been brought to lier to bring up. Perlaps having lost her own family made her take compassion on the kids, thus showing that 'a kindred feeling makes us wondrous kind' does not apply to the hmman race only."

A curious instance of sympathy is related by Tarly Is. :

"Losy's daughter was a curions tortoise-sliell, with four white paws, which were always kept particularly clean.

"TVhen she was nearly twelve months old I went into the room to breakfast, and perceivea both Rosy and Tiney outside the window, resting their front paw's on the window-frame, and carrying a dead kitten in their mouths, Rosy loolding the kitten of a few lours old by the back of the neck, cat-fishion, and Tiney snpporting the hind legs. Both mother and daughter were looking very solemn, as thongh soliciting sympatly for the death of 'I'iney's first-born cliila.

"Rosy has had a great many kittens since then, but Tiney never had another, though she has been most anxious and attentive to hel little brother and sister kittens; and whenever hosy left them longer than 'Iney considered prudent, she wonld call her and drive her to her baby littens, giving her an nnmistakable box on the ear and a scolding for lier neglect of her young ones.

"When they grew too large and heary for Rosy to carry alone, the pair always bore the burden between them, Rosy taking them by the neck, and 'liney the hind legs, as in the first instance. In this way they frequently mounted the stairs, and it was extrardinary to see how well they managed togrether.

"Your 'Tiney, who was a wonderful cat, and did most clever things, was lost while I was away from home for some months. Rosy has traveled about with me, and sits as quietly on my knee as a child would do. She likes to look out of the carriage window, and when any thing passing takes her fancy she puts her paw on my chest, and makes a pretty little noise, as though asking if I had seen it also."

There are many examples known of birds feeling sympathy witlı the lost or deserted young of other species, and taking upon themselves the task of feeding the starving clildren. The following case is really a remarkable one, for it is scarcely possible for two birds to be more unlike in their manners than the starling and the redbreast, the former being essentially a social bird, and the latter as essentially a solitary one, isolating himself with the greatest care, and always aplropriating to himself some district which he is pleased to consider as his own property, and in which he will not allow another redbreast to show himself. Indeed, he does not like a bird of any kind to intrinde upon his premises, and whenerer they show themselves they must be very strong birds indeed not to be attacked by this jealous defender of his rights. The follow'ing little history is taken from Hardwicke's Science Gossip for September, 1871 :

"A little redbreast lias come to our door all through the winter for his meals, and a most friendly, welcome gnest he has been. One spring morning we saw robin do a deed of charity that more than ever endeared the little bird to our hearts. It had been a bitterly cold night, and on onl servant going down-stairs to fetch some coul to light the fires, slie found a poor little 
starling shiveing and frightened in the cellar. She called me to see the bird: it had only just left the nest, and it was so weak that it could not fly. I tried to conx it to eat, took it near the fire, offered it bread-crumbs, seeds, water ; but no-the starling would not be tempted.

"Breakfast-time came, and with it the little robin. We thought that if we pnt the wee birdie out of doors its mother might come to look for her lost child; then came the fear of robin-he was so very pugnacious. Well, we risked it, keeping a very strict watch over the starling's safety. Robin eyed it for a moment, and flew away; still the little baby bird stood on one leg shivering, and no mother arrived. The moments seemed hours. Presently robin came flying back, and with sometling in his beak, too. Hop, hop, he came to where the wee baby starling was shivering, and popped a worm in its beak, which it opened, just as if robin lad said, 'Open your mouth-here is some breakfast ;' and away he flew, and again returned with some food to the young bird, and then they both flew away. We never saw the starling again, but good little robin's deed made him more loved than ever in the lionse."

I am rather glad to have the opportunity of making known these examples of sympathy between animals, because I have receired communications from persons who really appreciate the moral capacities of the lower animals, but who can not bring themselves to believe that they feel any sympatlyy with eacl other, though they do so for man.

We now pass to another branch of the subject, namely, the capacity of the lower animals to sympathize with human beings in distress. The following touching narrative is from the pen of a lady :

"Some years ago we possessed a large watchdog, a mastiff, who, when he became old, was allowed the free range of the garden.

"We also had a little skye terrier, whom he took into lis especial charge, walking with her, and apparently showing licr the rarious walks, flower-beds, etc. She had, unfortunately, one great fault, i.e., chasing the cat, who was also a pet. On one occasion she was taken in the act, and her master was administering a little castigation; whereupon the mastiff came np quietly to his master, and took his right arm in his month, not offering to bite, but asking him to withhold the coming stroke.

"The snccessor to this dog was a still more remarkable animal, belonging to the St. Bernard breed, named 'Nelly.' She came to us when " six weeks old, and died in November, 1862, lamented not only by the household of which she formed a part, but by the whole neighborhood. Even stranger's could not but notice her, for her face was full of soul, nobility, intelligence, and love.

"She was with us during a season of bitter bereavement. Her own altered looks, her quiet and sad demeanor, told how truly she shared in the prevailing sorrow. For many weeks she never entered the house (except the kitchen), but would often look wistfully up to the windows. At length, when she did venture into the diningroom, she merely walked direct to the well-known chair, and, finding it vacant, with saddened look turned away and left the room.

"As time rolled on, her visits to the house were renewed, and then it was that her sympathetic qualities were so touchingly displayed. She seemed to realize tlie change that had passed over us. She noticed onr indications of sorrow when we thought that she was sleeping, and, leaving the spot where she was lying, she would offer nis her paw with an expression of countenance which made itself felt.

"On more than one occasion she rose spontaneously from the warm ring, and, with a look which conveyed as impressively as words could do the sympathy which she felt, she rested her beantiful flaxen breast on the lap. of the lonely one, clasped her in her arms, and licked the tearbedewed cheeks."

'The last scene of Nelly's life was very remarkable, as showing the complete understanding and sympathy which can exist between man and the lower animals. She entertained the profoundest affection for the old gardener, affection which was perfectly reciprocated.

"'Her greatest trials were when George's duties called him away from her. At such times she used to station herself at the gate, engerly listening for the coming footstep, with now and then a piteous howl. And when he did appear, what a rush of delight! what greetings! what fondlings:

"But I must hasten to the last sad scene. Our" loving and much-loved Nelly died three days after giring birth to a litter of puppies. The best skill that was to be had was obtained, and her faithful George watched her by night and by day. With all a mother's forgetfulness of self, she fulfilled her maternal duties until the last day, when she eridently felt that she had nothing and could do nothing for them. She feebly rose from her coucl, and gave her children into George's charge, with a look that said as plainly as human words cculd speak, 'Care for these helpless ones 
as you have cared for me.' What could a human mother do more? She then lay on the couch, from which her children had already been remored, stretched herself ont, and, with her paws in the hand of her faithful friend, quietly breathed out her life.

"Can it be that virtues such as I have attempted to portray have found $n$ fitting sphere for their exercise, but that, like the poor perished body, they lave gone to destruction? Nay, even the body is not destroyed; it is only dissolved into other elements. Are we, then, to think that the all-wise Creator shows less respect for the immaterial than for the material; that while the inferior continues to exist, although in altered form, the superior is consigned to annihilation? Reason and analogy oppose it ; revelation does not support it."

I have witnessed an example of sympathy with human sufferings shown by a cat. Her name was "Prettina," and she was grandmother" of my own remarkable animal, who, although of a different sex, received the abbreviated name of "Pret," by way of honoring the memory of his beautiful grandmother. ()ne day, while I was paying a visit, the cat's mistress was seized with a distressing cough, which used to last for a considerable time, and left her quite prostrate with the fatigue. As soon as the cough began the cat became uneasy, and at last jumped upon the couch on which her mistress was lying, uttered a series of sounds which eridently expressed pity, and laid her paw on the sufferer's lips.

This, I heard, was her invariable practice whenever a fit of coughing was prolonged more than usual.

As for sympathy displayed by dogs, there is no need for me to give examples. I suppose that no human being was ever free from troubles of some kind, and I am equally sure that no one who had a companionable dog felt that he was without sympatly. Doggie knows perfectly well when his master is suffering pain or sorrow, and his nose pushed into his master's hand, or laid lovingly on his knee, is a sign of sympathy which is worth having, thongh it only exists in the heart of a dog. From that moment a bond has been established between the soul of the man and that of the dog, and I can not believe that the bond can ever be severed by the death of the material body, whether of the man or of the animal.

I know a case where a dog was always the consoler. It belonged to a large family, and, as will be the case in families, one of the children occisionally got into disgrace, and was punished. Whenerer this happened, "Flo" was sure to find ont the sorrowing child, and, by licking its face and offering many caresses, would show her sympathy. One of the children was peculiarly sensitive, and, as if conscious that she specially needed sympathy, Flo would be more demonstrative toward her than toward the others.

\section{FRIENIDSIIP.}

That friendship, which is another branch of love, exists among animals is a very well-known fact, exhibiting itself most frequently among domesticated animals. Horses, for example, which have been accustomed to draw the same carriage are usually sure to be great friends, and if one be exchanged the other is quite wretched for want of his companion, and seems unable to put any spirit in to lis work.

Dogs, too, are very apt to strike up friendship with each other, one or two examples of which I have alrendy mentioned under other headings. One of my friends has a little terrier called "I'incher," who had in some way managed to make friends with a great sheep-dog. 'This was an unpleasant animal, of a quarrelsome disposition, and was always fighting some other dog. On these occasions Pincher always used to r'm to the assistance of his friend, and give him material help by attacking his adversary in the rear, snapping and barking, and biting his heels. This was very good of P'incher, but it was scareely filir play to the other dog.

A very remarkable and affecting instance of friendship in a cat has been commmnicated to me by a lady:

"We had two kittens given us, fine, high-spirited animals, called 'Dick' and 'Trate.' They lived together happily for some time; but Kate was taken with fits, and, by the advice of the doctor, she was poisoned with prussic acid. She was buried far arvay from the honse, because Dick was so fond of her that we feared he would find her grave.

"He did not see Kate removed, and of course had no knowledge of his loss except by his own instinct. But he hmited every where for her, called her in his way, and after the first day refused to eat. He went about the house in the most tonching way, just like a person in grief, and at the end of three days he died.'

The love which this affectionate creature bore to his companion was stronger than life, and I can not believe but that it survived deatl, and that the two loving creatmres were again united in their own sphere of existence. 
Among the animals, friendship is not confined to one species, but sometimes exhibits itself in animals which might be supposed to be peculiarly incongrrous in their nature. Here, for example, is a case of friendship between a cat and a $\log :$

"A strong case of friendliness between cat and dog is to be witnessed in this loouse (near Guildford) at the present time. 'Two kittens, not related to each other, and about six weeks old, have been introduced into the house, at two different times, within the last seven or eight weeks. Instead of takiug alarm at the sight of onr big dog, they lick his face, bite his ears, and play with his tail; I believe they think that he wags it on purpose, and I am not sure but they are right; finally, when they are tired, they go to sleep beside him, so that it is not uncommon to find him with one kitten between his paws and the other leaning up against him; and if he walks about the house, one or both of the kittens will trot after lim. Neither of these little creatmres liad seen a large dog until they came to us."

That cows and sheep live, as a rule, on good terms in the same pasture is a familiar fact, though sometimes the former are a little apt to bully the latter. I have, however, learned that a very strong affection can exist between animals so different, and that when accustomed to each other's society neither could be happy without the other.

"Some years ago we had a lamb whose mother died soon after its birth. It was bronght up by hand on cow's milk, and, for the convenience of the feeder, was kept in the cow-lionse. It accompanied the cows to and from the field, and remained their companion for two or three year's.

"The animal was quite a pet of the man who had charge of the cows, and he kept it with them mintil ordered by his master to place it with the sheep. After much demur, this was done; but for' some days the man complained that 'Donald' was miserable, that he would not associate with the other sheep, and that they beat him. The master gave little heel to the statement, but at last gave permission for Donald to be restored to his old associates, and inrited ins to see the meeting.

"The cows all rushed to meet him, and he ran up to each in turn; but this was only a begimning. After a few minutes a cow went to Donald and began licking him from head to tail, and continued to do so until she had passed her tongue over every part of his body. He was then passed orer to another, who did the same thing, until all the six cows lad shown their affection."

That Donald should refuse to associnte with the other sheep is not a matter of wonder, as he had been accustomed from his birth to the society of cows; but that the others should bully him is not so easily explained, except on the supposition that from long familiarity with cows he had contracted habits that were unsheeplike, and gave him a foreign air.

Horses are apt to contract friendship with different animals. The goat and the loorse are frequent friends, and it often happens that a pecnliarly vicious horse will allow a goat to take any liberties with him without dreaming of resenting them. The stable cat, too, is quite an institution in many places, the cat's usual place of repose being the back of the horse, and the horse being uneasy if left for any length of time without the society of his usual companion.

I know of one case where the friendship was exhibited in a very curions manner. A little Fitten strayed, when very young, into the house of one of my friends, and was adopted by a cat who bronght it up together with her own young. This kitten became a great frequenter of the stables, and made two rather odd friends, namely, a pony and a lame bantam. It was a curious sight to see the kitten and the bantam curled up asleep on the pony's broad back, where they would spend hours without being disturbed.

The horse and the goose hare been known to be excellent friends for a long time, the bird rubbing his head, in the fondest manner, against that of the horse. I have mentioned, under another heading, the odd friendship that was struck up between a kitten and a brood of ducklings, the kitten always going to sleep on the ducks when they had settled down for the night.

Another odd instance of friendship occurred in the house of one of my friends.

He had a fine Newfoundland dog which took a fancy to a brood of young ducklings, and constituted himself their protector. They were quite willing to accept him in this capacity, and followed him about just as if he had been their mother. It was a specially interesting sight to watch the dog and the ducklings taking their siesta. The dog used to lie on his side, and the ducklings would nestle all about him.

There was one duckling in particular which invariably scrambled upon the dog's head, and 
sat on the eye which was uppermost, both par- live in a hen-house. He formed a friendship ties appearing to be equally satisfied with this with one of the inmates, a hen which was in remarkable arrangement, though the dog must bad health, and the two were accustomed to have been put to no small inconvenience by the sleep on the same perch, the monkey with his pressure on his eye. head nestled under the hen's wing.

It is really curious to notice the apparently I also know of two Java sparrows which alincongruous friendships which are often found among animals. ways pass the night under the wings of two turtle-doves, which treat them like their own I knew of a monkey who was accustomed to offspring. 


\section{CIIAPTER XIV.}

\section{O VE OF M A S TER.}

Attachment of Animals to Man._Innate Yearning for Human Society._ "Jimmie," the Squirrel.-A Tame Sparrow and its Ways._" Turey," the Rock-pigeon.-Bad End of a Pet.-Divided Allegiance.-The Dead Shepherd and his Dog.-Animals Dying for Love of MIal._" Phloss" and his Mistress._My Dog "Rory." - Ny Children's Canary.-Mr. Webber"s Account of the Bullfinch. -The Story of "Grayfriars' Bobby."A Well-deserved Monument.-Power Possessed by Animals of Returning to their Masters. -A Collier Dog Finding his Way from Calcutta to Scotland.- "Zeno's" Singular Journey.-A Dog and his Complicated Journey from Manchester to Holywell,-Cats and their Supposed Attachment to Localities.-My Cat "Pret" and his Travels.-A Cat Crossing Scotland alone.-Suggested Source of the Power.-A Stray Persian Cat.-The Dog "Joey" and his Mistress's Letter.-The Indian Fakirs and their Tame Tigers."Rob," the Bloodhound, and the Child.-The Boy and the Savage Horse.-Two Pet Sheep.-Goose and "Goosey."-"Toby," the Gander.-Summary of the Subject.

UNDER this heading $\mathrm{I}$ place that feeling which indnces animals to attach themselves to human beings, the feeling being the same whether the object of it be technically a master or not.

I have already referred to the intense yearning for human society which is felt by many of the lower animals, and which is incleed but the aspiration of the lower spirit developed by contact with the higher. In those animals which are domesticated, and therefore in perpetual contact with man from birth, this feeling is no matter of wonder. But that it should be exhibited in the non-domesticated animals and birds, and even, as we have already seen, in insects, is a fact which is well worth ou consideration, as giving a clew to some of the many problems of life which are at present unsolved.

The power of attraction which is exercised by the spirit of man upon the spirit of the lower creation is well exemplified by the well-known fact that many of the wild animals will attach themselves to human beings, and will forsake the society of their own kind for that of the being whom they feel to be higher than themselves.

One of the wariest animals is the wild squirrel, as any one will say who has tried to approach one. He is horribly afiaid of human beings, and if a man, woman, or child come to windward of a squirrel, the little animal is sure to scamper off at his best pace, scuttle up a tree, and hide himself behind some branch. Yet, as the following anecdote shows, the squirrel, wild as he may be, is peculiarly susceptible to the influence of the human spirit, and for the sake of human society will utterly abandon that of its own kind. The little history which is here given was sent to me expressly for this work:

"The squirrel was given to me while I was an undergradnate at Cambridge, in the summer of 1854 . He was very young, and could scarcely jump from the table. I took him home with me in the long vacation, and he soon became so fond of me that when I went for a walk I used to take him with me, and he followed me like a dog.

"Although he had one of those whirlabout cages, it was with difficulty that I could keep him there, as when awake he preferred to follow his own devices, and, when tired, he usually slept on a soft cushion on the sofa; or, if the doors were left open, he would find his way into some bedroom, and nestle under the pillows.

"At night he always used to sleep with me, though he was rather troublesome, as nothing escaped his notice, and he always tried every thing with a nibble. He used to hide things dreadfully, and ladies' work-boxes were perfect mines to him. I am afraid he was rather encouraged in this, as my mother generally had a nut reserved in the corner of her box.

"In the morning, while I was dressing, I used to open my window, when 'Jimmie' used to get out, climb down a rose-tree that was nailed to the wall, and amuse liimself by taking a run before breakfast. Afterward he nsually went out again, and played about the lawn and plantation for three or four hours, returning by the window, and going to sleep on his favorite cushion.

"Once, when I was staying from home, and had taken Jimmie with me, I lost him for two nights. He had been playing about in the gar- 
den, and, being in a strange place, had evidently lost his way. I was very unhappy ahout him, and had given him up for lost, when on the second day I heard his feet pattering near the door, and joyfully welcomed him back. When I came orer to Jersey, I brought my little friend with me; but in 1858 the poor little fellow caught cold, became paralyzed, and soon died, to my very great gricf."

The reader will observe that in this case there was a deliberate abandonment of frecdom and the company of his own kindred for the sake of human society. 'There was no coercion. If Jimmie had wished to escape, there was nothing to prevent him, and nothing bound him to his master but an "erer-lengt!ening chain" of love and aspirations which nonc but a human being could satisfy.

Here is an instance where a sparrow, one of the most independent and self-reliant of birds, abandoned his own kind for the sake of human beings :

"A lady, whom we know, tells rather a strange story about a spariow.

"Her brother's had rescued the bird from some boys who had been robbing the nest. They brought it home, and it was reared in the house. It was never confined in a cage, but was allowed to fly freely about the house. As a cat was kept, she had to bc watched lest she should injure the bird.

"On Sundays, when the whole family went to church, and no onc was left to keep an eye on the cat, the sparrow was always turned into the garden, where he flew about until the family returned. The signal for his entry into the house was that his mistress opence the dining-room window, and stood there without her gloves. If she wore her gloves, the bird refused to enter."

A somewhat similar instance is here given, the narrator being an artisan :

"Forty year's ago I was in Scotland, living with an uncle at an old castle called Cakemuir. There was a part in ruins, tenanted by quantities of pigcons, many of which were taken for pies. Among them was an unfledged young one, and I, then a boy, took compassion on the solitary thing, and begged it as a pet. I put it in a basket in an cmpty room, and fed it by hand; and it grew apace, and formed an everlasting friendship for me. It was a bright blue bird, with white lead and wings.

"When it was fledged, I gave it liberty, but it would never associate with its fellows. It followed me wherever I went, ercn for miles, tak- ing long flights, and returning to settle on my arms, head, or shoulders. It was a constant attendant in the breakfast-parlor, driving out the dogs and cats by blows of its wing.

"We remored to another house, where it was perfectly at home. There also it was a great pet with my uncle and annt, but it would nercr follow them. After a time I was apprenticed at a village a few miles off, and used to return on Sunday morning and spend the day there. 'Turey' followed me as usual on the Sundays, and when I returned on Monday would try to accompany me. At first I had to drive it back by throwing stones toward it; but it soon learned my intentions, and would only go with me as far as the road. On being told to go home, it would fly around my head, then make a great round in the air and fly home.

"Unfortunately it became troublesome, as most pets do, and used to get into the dairy and disturb the milk. My aunt shut it up, but forgot to give it any water, and the poor bird died of thirst. Many tears were shed, and we were obliged to let my uncle think that I had the bird with me in the village."

I am acquainted with two jackdaws, which behave in much the same manner. One of them entirely declines all intercourse with the jackdaw world, and attaches himself exclusively to the inhabitants of the house. He has the full use of his wings, but generally employs them in flying about the honse, and occasionally settling on the heads of persons to whom he chooses to take a fancy. I have had him on my head many times, and it was sometimes rather startling, when absorbed in a book or conversation, to see something black dash before one's eyes, to hear a loud squall of "Jack!" in one's ears, and then to feel the grasp of sharp claws on the top of the head.

The other jackdaw owns a divided allegiance. He does not enter the house, and freely consorts with his fellows. But he is always within, or, at all events, in sight of the garden, and is ready to greet any members of the family who leare the house. He will generally accompany them in their walks; and if they are accompanied by friends who are not acquainted with his ways, he is apt to startle them by an occasional swoop close to their lieads, accompanicd by a loud caw.

IIere is a case of divided companionship in a rook. The anecdote was communicated to me by a lady:

"In the early part of 1861 a young rook was brought to one of my children. It was womuded in the wing, and unable to fly; but every care 
was taken of it, and it soon recorered. IVe gave the bird its liberty; but during the whole of that year it kept abont the garden and close to the louse, always coming to be fed when called.

"He remained with us for some years, when he suddenly disappeared. We feared that he might have been shot; but, to our surprise, about the month of June 'Jack' again made his appearance, sitting in his accustomed place in a tree opposite the window. From that time he hats been a constant attendant, coming to us when we call him, and following us from place to place. At other times he joins his companions, and flies about with them, only returning to us to be fed.'

The following pathetic little tale shows how the love of master in a dog survived death. It shows reasoning and self-denial on the part of the dog, and also affords another example of the inamner in which the power of reason in an animal seems to break down just where it might be expected to manifest itsclf most successfully :

"Some years ago a fearful snow-stor'm happened in the Isle of Skye. A shepherd had occasion to go to look after his flock, attended by a faithful dog. 'The storm increased, and the yoor shepherd could not accomplish his task; night had set in, and he was unable to return to luis home. Struggling in vain through the drift and darkness, he becanıe utterly exhausted, lay down and died.

"The dog, more fortunate than his master, got back to the lonely sheiling; and when it was seen that he was alone, search was made, but in vain. Hope was giving way to despair, when it was observed that the $\operatorname{dog}$ daily took away at piece of bannock, or cake, in his mouth, as it was thought to hide it for some future occasion. But, with that noble instinct with which a wise Providence had endued lim (although in this instance unavailing), he set off day by day with this supply to where his master lay, and on being followed it was found that he had placed no fewer than five pieces of bread on his breast. Alas? the vital spark had long since fled, but there was the striking token of instinct and affection, meet subject for even a Landseer to depict."

The intensity of the love which the lower animals can entertain toward man may be estimated from the fact that they have been known to die for the loss of those whom they love. I give three instances of such potent grief, two being exhibited by $\operatorname{dogs}$, and the other by a canary which lived in my own family for some years. The first anecdote is taken from the wcll-known "Memorials of a Quiet Life," by Angustus Hare:
" Her poor old dog, 'Phloss,' pined away from the moment of his mistress's death. He pined and rexed himself whenever the undertakers came to the house, and on the night before her fumeral laid himself down and died-died, as the servant said, just like his mistress, with one long gasp of breath. Thus ended a life bound up in our recollections with 'Julius,' with Havelock, from whom it derived its name, and Julius's dear friend, 'Tom Starr, by whom it was given."

Then there was my dear dog "Rory," the quaintest, fumniest, and most eccentric dog that I ever knew. A rough Irish terrier, black as night, with a triangular patch of snowy white on his breast, and another on the under side of his tail-tuft; thick, heary eyebrows, with a bold curve in them, only letting the gleam of the glittering eyes sparkle from between their fringes; black moustaches to match the eyebrows, only very much longer and thicker ; and ears standing nearly upright for half their length, and then abruptly drooping as if made of black velvet.

I call him $m y$ dog, not because he ever belonged to me, but because he was pleased to adopt me as his master, and totally to repudiate his legal owner, who, by the way, very lonorably paid the tax for him.

Shortly after taking my degree, I accepted a scholastic offer which took me into Wiltshire, where it was impossible to introduce Rory. So, with many regrets, I left him to the care of the household, all of whom were very fond of him.

Of course, he was greatly troubled at my absence, and was perpetually on the watch for me, but after some weeks he secmed to understand the state of things and to be rcconciled to his lot. It so happened that after I had been away for some three months, I had to attend to some family business, and visited home for a few hours. Rory was there, and gave me the most curious welcome imaginable.

Naturally a dog of the most exuberant spirits, exalted to the skies by a kind word, and crawling on the ground in utter abasement if scolded, he might have been expected to be mole than usually demonstrative when I unexpectedly made my appearance. But he did nothing of the kind. He licked my hand, and that was all. But he would not lose sight of me. He followed me silently about the house, and, when I sat down, lay on the floor, with his chin resting on my foot, and his beantiful loving eyes gazing steadily and wistfully at me through their heary fringes. He seemed to know that it was for the last time, and kept his steady gaze until I was obliged to leave the house. He made no particular demon- 
stration when I bade him farewell; but his lawful owner claimed him, took him away, and in a few weeks iny poor Rory was dead.

There are several now living who will always cherish an affectionate regard for Rory and his odd ways. No human being eould have possessed a keener sense of humor than had Rory, and no one could have been more fertile in hitting upon plans for gratifying that sense of humor. He would knock over every fat lap-dog that he met, frighten their mistresses half ont of theiv senses, walk by their sides on his hind legs the whole length of a street, and altogether eomport himself like an amiable miniac. He chiefly exulted, however, in alarming college dons as they statelily sailed along in the full glories of silken gown, eassock, and scarf. Such, at least, was the eustom in my time, now some thirty years ago; but $I$ am given to understand that in these degenerate days the undergraduates wear moustaches, and a don looks like any body else.

Perhaps that very sense of the ridiculous which was gratified by seeing so stately a being lose all lis dignity in instant and groundless alarm was owing to the susceptibility of disposition which, on the one side, hurried him into absurd extravagances, and, on the other side, eost him his very life in disappointed longings for the presence of his self-chosen friend.

The case of the canary was as follows:

It belonged to the head nurse, and was kept in the day-nursery with the children. At all mealtimes the eage was always plaeed on the table, and the bird received much notice. It so happened that the children went away for a few weeks' visit. Although the nurse had the bird in her room, it pined for the society of the ehildren, refused to eat, and in a day or two was found dead at the bottom of the eage.

The following story is related by Mrs. Webber in "The Song-birds of America," and shows how a bird aetually died because he thought that he had lost the love of his mistress.

Mrs. Webber had just lost a pet thrush, and was inconsolable. However, a piping bullfinch was brought as a present, and liked to teach her the airs which he knew. At first the bereaved lady would not listen to him, but his winning ways quite overeame her.

"Altlough I still said I did not love him, yet I talked a great deal to the bird; and as the little fellow grew more and more cheerful, and sang louder and oftener each day, and was getting so handsome, I found plenty of reasons for increasing my attentions to lim; and then, above all things, he seemed to need my presenee quite as much as sunshine; for if I went away, if only to my breakfist, he would utter the most piteous and incessant cries mntil I returned to him; when, in a breath, his tones were changed, and he sang his most enchanting airs.

"He made himself most fascinating by his polite adoration; he never considered himself sufficiently well dressed; he was most deroted in lis efforts to enchain me by his melodies; art and nature both were called to his aid, until, finally, I could no longer refrain from expressing in no measured terms my admiration. He was then satisfied, not to cease his attentions, but, to take a step further, he presented me with a straw, and even with increased appearance of adulation.

"From that time he clainied me wholly; no one else could approach the cage ; he would fight most desperately if any one dared, and if they laid a finger on me lis fury was unbounded; he would dash himself against the bars of his eage, and bite the wires, as if he would obtain his liberty at all hazards, and thus be enabled to punish the offender.

"If I went away now, he would first mourn, then endeavor to win me back by sweet songs. In the morning I was awakened by his eries, and if I but moved my hand his moans were changed into glad greetings. If I sat too quietly at my drawing, he would beeome weary, seemingly, and call me to him; if I would not come, he would say, in gentle tone, 'Come-e-here! come-e-here!' so distinctly that all my friends recognized the meaning of the aeeents at once; and then he would sing to me.

"All the day he would wateh me: if I were clieerful, he sang and was so gay; if I were sad, he would sit by the hour watehing every movement; and if I arose from my seat, I was called 'Come-e-here ;' and whenever he could manage it, if the wind blew my hair within his cage, he would cut it off, ealling me to help him, as if he thought I had no right to wear any thing else than feathers; and if I would have hair, it was only suitable for nest-building. If I let him fly about the room with the painted fineh, he would follow so close in my footsteps that I was in constant terror that he would be stepped upon, or be lost, in following me from the room.

" $A \mathrm{t}$ last he came to the conclusion that I could never build a nest. I never seemed to understand what to do with the nice materials he gave me; and when I offered to return them, he threw his body to one side, and looked at me so drolly from one eye that I was quite abashed. From that time he seemed to think I must be a very young creature, and most assiduously fed me at stated periods during the day, throwing up from 
his own stomach the half-digested food for my benefit, precisely in the manner of feeding young birds.

"But I did not like this sort of relationship very much, and determined to break it down; and forthwith commenced by coldly refusing to be fed, and, as fast as I could bring iny hard heart to do it, breaking down all the gentle bonds between us.

"The resilt was sad enougl. The poor fellow could not bear it : he sat in wondering grief -he would not eat; at night I took him in my hand, and held him to my cheek: he nestled closely, and seemed more happy, although his little heart was too full to let him speak. In the morning I scarcely answered his tender love-call, 'Come-e-here;' but I sat down to my drawing, thinking if I could be so cold much longer to such a gentle and uncomplaining creature.

"I presently arose and went to the cage. Oh, my poor, poor bird! he lay struggling on the floor. I took him out-I tried to call him back to life in every way that I knew, but it was useless; I saw he was dying-his little frame was even then growing cold within my warm palm. I uttered the call he knew so well; he threw back his head, with its yet undimmed eye, and tried to answer ; the effort was made with his last breath. His eye glazed as I gazed, and his attitude was never changed. His little heart was broken. I can never forgive myself for my cruelty! Oh, to kill so gentle and pure a love as that!"

Many of my readers will anticipate the subject of the next few pages, namely, "Grayfriars' Bobby," a dog whose love of its master long survived death. I have been acquainted with the story of this faithful animal for many years-long, indeed, before the touching narrative was made jublic through the very prosaic medium of the tax-gatherer.

In the Scotsman of April 13, 1867, the following narrative appeared :

"A very singnlar and interesting occurrence was yesterday brought to light in the Burgh Court by the hearing of a summons in regard to a dogtax. Light and a half year's ago, it seems a man named Gray, of whom nothing now is known, except that he was poor, and lived in a quiet way in some obscure part of the town, was buried in Old Grayfriars' Church-yard. His grave, leveled by the hand of time and unmarked by any stone, is now scarcely discernible; but, although no human interest would seem to attach to it, the sacred spot has not been wholly disregarded and forgotten. During all these years the dead man's faithful dog has kept constant watch and guard over the grave; and it was this animal for which the collectors sought to recover the tax.

"James Brown, the old curator of the burialground, remembers Gray's funeral, and the dog, a Scotch terrier, was, he says, one of the most conspicuous of the mourners. The grave was closed in as usual, and next morning 'Bobby, as the dog is, called, was found lying on the new-made monnd. 'This was an innovation which old James could not permit; for there was an order at the gate stating, in the most intelligible characters, that dogs were not admitted. 'Bobby' was accordingly driven out; but next morning he was there again, and for the second time was discharged. The third morning was cold and wet; and when the old man saw the faithful animal, in spite of all cliastisement, still lying shivering on the grave, he took pity on him, and gave him some food.

"This recognition of his devotion gave 'Bobby' the right to make the church-yard lis loome; and from that time to the present he has never spent a night away from his master's tomb. Often in bad weather attempts have been made to keep him within doors, but by dismal howls he has succeeded in making it known that this interference is not agreeable to him, and latterly he has always been allowed his own way. At almost any time during the day he may be seen in or about the churchyard; and no matter how rough the night may be, nothing can induce him to forsake the hallowed spot, whose identity, despite the irresistible obliteration, he has so faitlffully preserved.

"Bobby has many friends, and the tax-gatherers liave by no means proved his enemies. A weekly treat of steaks was long allowed him by Sergeant Scott, of the Engineers; but for more than six years he has been regularly fed by Mr. Traill, of the restaurant, 6 Grayfriars Place. He is constant and punctual in his calls, being guided in his mid-day visits by the sound of the time-gun. On the ground of harboring the dog, proceedings were taken against Mr. Traill for payment of the tax. The defendant expressed his willingness, could he claim the dog, to be responsible for the tax; but so long as the dog refused to attach himself to any one, it was impossible to fix the ownership ; and the court, seeing the peculiar circumstances of the case, dismissed the summons.

"Bobly has long been an object of curiosity to all who have become acquainted with his history. His constant appearance in the grave-yard has caused many inquiries to be made regarding lim, and efforts without number have been made to get possession of him. The old curator, of course, stands up as the next claimant to $\mathrm{Mr}$. Traill, and yesterday offered to pay the tax him- 
self rather than have Bobby-Grayfriars' Bobby, | to allow him lis full name-put out of the way."

Four years longer the faithiul little dog kept his loring watch, and at last died, to the regret of all who knew him, never having been ont of reach of his master's grave; though in his later years the infirmities of doggish age forced him to accept a partial hospitality of the curator. I ain sure that Lady Burdett-Coutts gladdened the hearts of many lovers of animals - as she certainly did mine-when she perpetuated his memory by a lasting monument of granite and bronze. The monument is a drinking-fountain made of Peterhead granite, and surmounted by a life-size statue of Bobby in bronze.

During the many years which elapsed between the death of his master and his own departure, the lowly grave was forgotten by all but the dog. No stone guarded it, and not even a mound marked it. The grass and weeds grew luxuriantly orel it as over the level soil around. There has been for years nothing that conld mark out the grave from the surrounding soil, but the little dog knew the sacred spot under" which lay his master's remains, and for homrs used to stand upon it, keeping his guard. A little way from the grare is an altar-tomb, under which Bobby used to shelter himself in bad weather, and to which he always used to take the bones and other food provided for him by the generous persons whose names have already been mentioned.

I possess three photographic portraits of Bobby. One represents him as standing upon the nameless grave, which is utterly indistinguishable from the weeds and herbage around. 'The portrait is not quite so good as it might be ; for just as the photographer had got the dog into focus, and had uncovered the lens, Bobby unfortunately caught sight of a dog passing the gate of the church-yard, and, according to custom, flew at him furionsly. He did not seem to object to human beings, but a dog he never would permit to be even in sight.

The best of the three portraits is that from which the bronze statne has been taken. He is sitting on the altar-tomb above mentioned, and is looking upward with that wistful, patient, longing, yearning expression of countenance which was peculiar to the animal, and is conspicuous in all the photographs, however imperfect they may be.

Some animals, notably dogs, have a wonderful power of returning to their belored master, even thongh they have been conveyed to considerable distances. So many examples of such feats are on record that I refrain from mentioning them, and only give one or two, the truth of which is gnalanteed by iny correspondents, whose letters I possess.

"A gentleman in Calcutta wrote to a friend living near Inverkeithing, on the shores of the Firth of Forth, requesting him to send a good Scotch collie dog. This was done in due course, and the arrival of the dog was duly acknowledged. But the next mail brought accounts of the dog having disappeared, and that nothing could be seen or heard of him. Imagine the astonishment of the gentleman in Inverkeithing when, a few weeks later, friend Collie bounced into his house, wagging his tail, barking furionsly, and exhibiting, as only a dog can, his great joy at finding his master.

"Of course all inquiry was made to find out how Collie got home again, when it was discovered that he had landed from a collier which had returned from Dundee. Inquiry was made at Dundee, when it was found that the dog had come there on board a ship from Calcutta. Now it can be understood that the dog might have recognized the collier, as he might have seen the vessel on some former occasion at Inverkeithing; but low he should have selected, at Calcutta, a ship bound for Dundee is not so easily explained."

There is one solution of this remarkable problem which has occurred to me. Probably the dog, not liking the strange land and the dark faces, had slipped back to the ships with which he had been familiar at home. Recognizing the well-known Scotch accent on board one of the ships, he must have got quietly on board, and, on landing at Dundee, transferred himself to the collier. This is merely conjecture, but I do not see any other mode of accounting for the dog's wonderful journey.

A scarcely less wonderful feat was performed some time ago by a dog which returned to his mistress from a distance. It is true that Manchester is not so far from Holywell as India is from Scotland; but the jomney, though shorter, was very much more complicated, and involved several modes of locomotion, some of which, at least, must have been adopted by the dog. The narrator of the story is my friend, the late $\mathrm{J}$. Hatton, M.D., whose name has been perpetuated on a life-boat presented by his widow to the Dungeness station :

"Some years ago, when I lived in Manchester, I attended, for fever, a mechanic, who worked for Messis. Sharp, Boor's, \& Co., the celcbrated locomotive-engine makers. When he becane convalescent, he went to the louse of his mother, 
who then lived at IIolywell, in Wales. After he had recruiteci his health, and was about to return home, his mother gave him a dog.

"He led the animal from Holywell to Bagill by road, a distanee of about two miles. Thence he took the market-boat to Chester, a distance of about twelve iniles, if I remember right. 'Then he walked through Chester, and took rail for Birkenhead. From that station he walked to the landing-stage and crossed the Mersey to Liverpool. He then walked through Liverpool to the station at Lime Street. Then he took rail to Manehester, and then had to walk a distanee of a mile and a lialf to his home.

"This was on Wednesday. He tied the dog up, went to his work on Thursday as usual; and on the Sunday following, thinking that the dog was aeeustomed to the plaee, he set it at liberty. He soon lost sight of it, and on the Wednesday following he reeeived a letter from his mother, stating that the dog had returned to her. Now you will see that the dog went first by road, then by market-boat, then through streets, then by rail, then by steamer, then through streets again, then by rail again, and then through streets again, it being dark at the time; and yet the dog had sagacity enough to find its way back to the seene of its early reeollections."

In this, as in other stories of a similar eharacter, one of the most eurious points is the extrene rapidity with whieh the animal made the journey. I do not know whether the marketboat ran on Sunday, but, at all events, the dog must have achiered the distance in some fortyeight hours.

That the $\operatorname{dog}$ in question retained a remembrance of the route by whieh he had traveled, and knew how to arail himself of the means of transit, I have no doubt whatever ; and this notion is eonfirmed by the behavior of a dog that belonged to one of my eorrespondents, Mr. B., who has kindly sent me several dog-biographies that eame within his own experienee.

He was then living in East Lothian, and had given the dog, a prize greyhound, to a friend who lived at Greigston, near Cupar, in Fife. His new owner took him home, but in a few days the dog was missing. His owner advertised lis loss, and the animal was eaptured on the pier at Burntisland, evidently waiting for an opportunity to cross in the steamer, whenee he would undoubtedly have found his way baek. This pier is fully twenty miles from the spot which he deserted.

I ean easily understand how a dog would manage to slip on board by pretending to belong to one of the passengers. Dogs are quite alive to the soeial distinetion between those who belong to some partienlar owner and those who are masterless, the latter being looked upon by themselves much as a "masterless man" was regarded in the time of Elizabeth, $i$. e., a sort of social outeast, maeknowledged by his fellows.

I owed the life-long friendship of my inimitable Rory to this feeling. He was none of my dog. He belonged to a man of another eollege, with whom I had hardly exehanged half-a-dozen sentences. His master was obliged to eross the sea during the long vaeation, and left the dog in the charge of his scout.

Being always of an aristocratic turn of mind, Rory repudiated the scout altogether, and, remembering that he had been in my rooms at Merton, he paid me a risit one morning, and engaged me as his master. It was not the least use to take him baek, for he always returned in an hour or two; and at Jast it was taeitly agreed that he should retain possession of me. He knew the value of a eollegiate master, and was not going to be fobbed off with a seout. His legitimate master having deserted him, he exereised his right of selecting a master for himself, and aceordingly he elose me, and kept me, and when we were parted he died of grief, as has already been narrated.

I know another dog who displayed great wisdom in eseaping the snares of London life.

He was a beautiful little dog, just the animal whom a professional dog-stealer would be sure to snap up, if possible. One day he had been for a drive with his mistress, and, on being allowed to alight with her, had in some way been separated from her. After a rain search she drove home, and sent the servants to try and find her lost pet. He was presently diseovered by the coachman trotting quietly homeward, not in haste like a lost dog, but with a eomposed air, and pretending that he belonged to some one who was going in the same direetion.

I have seldom met with a more curious example of the ability of a dog to find his master than is related in the following story:

"Some year's ago, when I lired in Fife, I was eoming to Edinburgh with my eldest daughter. Zeno aeeompanied us to the station, about a mile from home; and as I did not wish him to come any farther, I asked a gentleman who was living with me to take him home.

"Just as the train was about to start I looked out to see if he had gone, when I saw him following my friend up the stairs at the station. We rattled along for a distance of about twelve 
or fourteen miles till we reaehed Burntisland, where we had to cross the forth.

"T'he day became very cold, with snow and sleet, so we hurried down to the steamer. We had left the pier about ten minutes when a passenger, wishing shelter, opened the saloon-door, when, to my great surprise, in walked Zeno, sniffung lis way up till lie came to me and jumped upon my knee. How he came was a mystery to me, and ever will be. All the carriages were shut when I last saw him. I think that he must lave returned and got into the guard's van ; but no one could tell me, and the strange thing was that he did not get out at any intermediate station.

"I still have the old dog, and he is as dear to me as ever. Never was there his like: never did he bite, though teased by children and grandchildren. His life is now one of constant repose; and when the cord will one day snap which will sever our long and faitlıful connection, I shall mourn his loss as that of a friend.

"Talk of 'dumb animals' - we might well take lessons from them in many things; they would even put many to shame. Yes, oul's is a higher and a noblel destiny; but yet, withal, methinks we might learn to profit from mueh we both know and hear of in the lives of our animal friends and relations."

The reader will perhaps remember that Zeno has already been mentioned under the head of "Jealousy."

It is often, but erroneously, said that eats are selfish aninals, attaching themselves to localities and not to individuals. 'This idea has, perhaps, some ground of truth, for it is not so easy to understand the nature of a cat as that of a dog; and when a cat is not understood, it is very likely that she cares less for the inhabitants of a house than for the honse itself. But I know of many instanees where cats have been in the habit of moving about with their owners, and have been as mnconcerned as dogs would have been.

My own cat "Pret," for example, was first taken from a small house at Greenwich to a liarge one in the very heart of the city, where he liad the range of many eellars, but no open air. Next he went to another large house in the city, where he had no cellars, and could only get on the leads by special permission. 'Then he was moved into a house in the country, where he had neither eellars, leads, nor tiles, but a garden. After that we moved to a larger louse in the same village, whither he followed us of his own aeeord.

His mother, "Minnie," always aeeompanied her mistress when she was on a risit, and I have more than once taken Minnie to her mistress for a journey of several miles. Here is a corroborative lettel from a lady :

"I believe, for my part, that cats attach themselves to people and not to places. Our cats always seemed to know their masters. One, belonging to my sister, would scratch all the rest of the family, though quite gentle with her. We traveled about once for a year and a lalf with a favorite cat; though during that time we changed our lodgings many times, she never left us. She even seemed to know our rooms, and kept to them when there were other apartments in the same house. She nised to knock at the door when she wanted to come in, and would endeavor to tur'n the handle by taking it between her paws. I have also seen her, when she was thirsty and eould not reach the water in the jug, dipping her paws in to get it in that way. She would follow my brothers around the room when they whistled a tune, and rub her liead against their hands and face, and touch their lips with her paw, as if pleased with the sound."

Perhaps the reader may remember the history of Lady E.'s cat Rosy, on p. 109, in which it is incidentally mentioned that she always traveled with her mistress.

My late esteemed friend, Mr. W. Chambers, called my attention some years ago to a story of a cat, which showed that the attachment of the animal toward man is much stronger than toward locality. He guaranteed the truth of the statement, and furnished me with the name and address of the person to whom the eat belonged. The story is briefly as follows:

A man and his wife, living in the northern part of Seotland, near the west const, had to move to a plaee on the east coast. In consequence of the expense of taking furniture by land, they traveled by sea, passing around the northern point, and landing near their new home. Having been told that eats only cared for localities and not for human beings, they, meaning all kindness, left the animal behind them. They, however, had not been long settled in their new home, when the man, on returning from work, saw a cat sitting on the wall, and found that it was actually his own eat, who, by some mysterious means, had found him ont. She was hungry, emaciated, and tired, and had evidently traveled by land to the same spot which they reached by sea. The power by which she did it may be instinet, or it may be the exercise of a ficulty not possessed by man. But I have related the anecdote to show how great must have 
been the love felt by the cat for its master, when it left the home which it knew well, and took a loug and fatiguing journey to join its master in a house which it did not know.

The following anecdote shows that the cat does love people more than places:

"Last summer we were staying for some weeks at Victoria Place, Eastbourne, and every morning the town-crier came in front of our house, giving out the public amusements for that evening, and a list of articles lost. Judging from the large number of things daily missing, either visitors or inlrabitants must have been a most careless race. He was the most amusing crier I erer heard, making his announcements in a semi-dramatic style and tone, which, together with a good roice and most pompous delivery, rendered thcse minor affairs quitc important. One of the missing items espccially attracted my attention.

" 'Lost, a tortoise-shell cat, of the Persian breed, with a velvet collar around its neck, rather old and very shy. Whoever will bring it to the Crier, dead or alive, shall receive ten shillings reward.'

"This was repeated for many days, and then the reward was increased to one sovereign, with the intimation that no larger sum would be offered. At about the end of three weeks the 'Cat' was taken off the list, and I inquired after the fate of poor pussy.

"The cat, which was of rare beauty, had becn brought to this country as a present to Lady _and had for years accompanied her when traveling. Soon after their arrival at Eastbourne, that love of liberty inherent in all animals, and a due appreciation of the surrounding scenery, induced pussy to stray into the woods, where she was at first hunted as a wild cat, and afterward chased and shot at to obtain the offered reward. She contrived to escape all these dangers, and existed on the few wild birds that she could catch, until Lady — heard of her whereabouts and went in search of her. The poor half-starved pet, on hearing the voice of her mistress calling her name, jumped on her shoulder, and thus terminated her rambles in the wild woods. It is a most dangeroús mistake to offer a reward for a lost pet, 'dead or alive' - the addition of the former word, while facilitating its capture, oftentimes proving its death-warrant."

The same lady, who communicated the preceding anecdote, has farored mc with two more, showing the attachment felt by dogs to their masters :

"A friend of ours, a great traveler, who has generally several dogs of rarions brceds, always takes one of them with him, making it a rule to take a different dog each royage, in order, as he says, 'to give them all a foreign education ;' home occupations preventing him from bestowing much time upon them when in England. Our dogs do not have this advantage, being generally left at home during our absence in charge and under the tuition of an old housekeeper.

"A remarkable instance of the power of scent was manifested by our little Maltese dog, 'Joey.' Our travels are often long in duration, and far distant; but, however numerons the post-offices through which our letters passed, he could always distinguish them from others, evincing great joy when allowed to smcll them, and often trying to obtain possession. He was anxiously watching the postman's knock one morning, when several letters arrived. Accidentally they all fell to the ground. Joey took advantage of his position, selected ours, and rushed off in great glee, giving the old housekecper a famons run around the garden, and then most decidedly refusing to give up his prize. She was obliged to adopt the expedient of slipping the letter (slightly damaged) out of the envelope, and allowing him to retain the latter, which he' carried off in triumph to his basket."

This is the same dog of whom several anecdotes have already been related, showing his great mental capacities.

As far as I can learn, all animals have not only a capacity for the society of men, but an absolute yearning for it. This feeling may be in abeyance, as having received no development at the hands of man; but it is still latent, and may be educed by those who are capable of appreciating the character of the animal. Tiger's, for example, are not generally considered the friends of mankind, and yet the Indian fakirs will travel about the country with tame tigers, which they simply lead with a slight string, and which will allow themselves to be caressed by the hands of children without evincing the least disposition to make a meal of them.

In the case of domestic animals, even the fiercest of them have this innate longing for human society, and will indulge it when they have the chance. This chance generally occurs by means of confidence on behalf of the human being. The animal is surprised to see some one who is not afraid of him, and so gives his confidence in return. The reader will perhaps remember how that eminently ferocious "Mess" became my very good friend. A somewhat similar case has just been related to me. 
A little girl, about two years old, wandered from her nurse, and was lost. At last the child was found asleep in the kennel of a peculiarly savage bloodhound, named "Rob." The dog was jealously guarding his little charge, and would let no one approach until the mother came. She called the child, who came to her, followed by Rob. She took the child home, but Rob insisted on accompanying them ; and as they went, the little girl held her mother with one hand and Rob's ear with the other-the child being so small, and Rob so large, that he had to walk all the way with his head bent down.

I have read an account, but do not recollect where, of a boy who went into a stable inhabited by a notorious "savage." He did not know the character of the animal, gave him bread and other delicacies, and the horror of the groom may be imagined when one day he found the boy and the horse lying together on the floor of the stable-the boy not having the slightest idea of the character of the horse, and the horse not having the least intention of hurting the boy, but cherishing him as a valued companion.

I have now the pleasure of giving a few little histories showing the affection which is often entertained for man by animals which he is not generally accustomed to consider as his companions. I have already mentioned an instance of fricndship between a sheep and cows, and I now give two examples of the same attachment of sheep to man:

"We had a pet lamb, which was fed by the cook. When the lamb was about six weeks old, the cook became ill, and was confined to bed for some days. While she was ill, the lamb left its usual place of abode, lay beneath her bed, and refused all food, although the milk was offered from the usual bottle. It did not seek nor worry the sick servant, but lay perfectly quiet under her bed.

"A pet sheep of my late brother has come to end its days with us at Bassendean. 'This shecp was the constant ont-door companion of my brother and his niece. They were, howcrer, obliged to give up walking with him, for he would insist on pusling his way between tlem, and wonld not condescend to walk on one side."

We are rather apt to consider the goose (inclurling gander) as a peculiarly stupid bird, and to use its name, as we do that of the ass, as a synonym for folly. Yet a greater mistake could not be made in either case. We have already been told of an ass which his master was obliged to sell because he was too clever to be kept, and led the other animals into mischief. Tlie same writer now tells us a story of affection between a goose and a man:

"A goose-not a gander-in the farm-yard of a gentleman, was observed to take a particular liking to her owner. This attachment was so uncommon and so marked that all about the house and in the neighborhood took notice of it ; and, conscquently, the people, with the propensity they liave to give nicknames, and with the sinister motive, perhaps, of expressing their sense of the weak understanding of the man, called him 'Goosey.' Alas for his admirer, the goose's true love did not yet run smooth; for her master, hearing of the ridicule cast upon him, to abate her fondncss, insisted on her being locked up in the poultry-yard.

"Well, shortly after he goes to the adjoining town to attend petty sessions; and in the middle of his business what does he feel but something wonderfulty warm and soft rubbing against his leg; and on looking down he saw his goose, with neck protruded, while quivering her wings in the fullness of enjoyment, looking up to him with unutterable fondness. This was too much for his patience or the by-standers' good-manners; for, while it set them wild with langhter, it urged him to a deed he should ever be ashamed of ; for, twisting his thong-whip about the goose's neck, he swung her round and round until he supposed her dead, and then he cast her on the adjoining dunghill.

"Not very long after, Mr. Goosey was seized with a very sevcre illness, which brought him to the verge of the grave; and one day, when slowly recovering, and allowed to recline in the window, the first thing he saw was his goose, sitting on the grass, and looking with intense anxiety at him. The effect on him was most alarming.

"' What!' says he, 'is this curscd bird come back to life? and am I, for my sins, to be hauntcd in this way?'

"' 'Oh, fitther,' says his daughter, 'don't speak so hardly of the poor bird. Ever since your illness it has sat there opposite your window; it scarcely takes any food.'

"Passion, prejudice, the fear of ridicule, all gave way before a scnse of gratitude for this unutterable attachment. The poor bird was immediately taken notice of, and treated from henceforth with great lindness; and, for all that I know, goose and Goosey are still bound in as close ties as man and bird can be."

The second story, told by the same writer from his own observation, has such a tragic conclusion 
that I could hardly make up my mind to print it. I never could look upon lim afterward without There is in both cases extraordinary love, amount- a sense of dislike. I did not either expect or deing indeed to worship, on the part of the bird to- sire that he should suffer as he who slew the alward man. In both cases there is not only a want of reciprocity, but actual ingratitnde, on the part of the man toward the bird-redeemed, however, in the preceding aneclote by repentance and reciprocation of friendship :

"I must tell you, among many anecdotes I know of geese, one that came under my own observation. When a curate in the county of liildare, my next neighbor was a wortly man who carried on the cotton-printing business, and who, though once in very prosperous circumstances, was now, in consequence of a change in the times, very poor.

"In his mill-yard was a gander, who had been there forty years; he was the largest bird of his kind I ever saw. His watchfulness was excessive: no dog conld equal him in vigilance, neither could any dog be more fierce in attacking strangers or beggars; he followed his old master wherever he went, and at his command would fly at any man or beast; and with his bill, wings, and feet he conld and wonld hurt severely.

"Whenerer my neiglıbor paid me a risit, the gander always accompanied him; and as I was liberal of oats, and had besides one or two geese in my yard, he would, before his master rose in the morning, come up and give me a call; but neither the oats nor the blandislments of the feathered fair conld keep him long away, and he soon solemnly stalked back to his proper station at the mill.

"Well, year after" year I was perfecting my friendship with 'Toby, the gander, and had certainly a large share in his esteem; when one winter, after being confined to the house with a severe cold, I, in passing through the mill-yard, inquired for my friend, whom I could nowhere see.

" 'Oln, sir,' said the man-and he was about the place as long as 'Toby himself- 'Toby's gone.

" 'Gone where?'

" " $\mathrm{Oh}$, he is dead.'

" "How! dead?"

" "Why, we ate him for our Christmas dinner."

" "Ate him!'

"I think I have been seldom in the course of my life more astonished and shocked. Positively I would have given them a fat cow to eat, could I liave saved poor 'Toby ; but so it was. Upon inquiry, I found out that the poor gentleman had not means to buy his Christmas dinner; that he was too prond to go in debt, and, determined as he was to give his people a meat dimmer, poor Toby fell a sacrifice to proud poverty. While honoring the man for his independence, I confess batross, but I was sure that he would not be the better in this world or the next for killing the gander."

In which sentiment I, and I hope all my readers, most cordially agree.

Surveying all these examples of love displayed toward human beings by animals, it is impossible really to believe that such love can die. Unselfish love such as this, which survives even ingratitude and ill-treatment, belongs to the spirit and not to the body, and all beings which are capable of feeling such love must possess immortal spirits. All may not have an opportunity of manifesting it, but all possess the capacity, and would manifest it openly if the conditions were favorable.

We will just run over the anecdotes which I have given. In those of the squirrel, the sparrow, the blue pigeon, the jackdaws, and the rook, we have examples to show that even in the wild animals the love of human beings can overpower that of liberty and of their own kind, and that they will forsake both liberty and their kinsfolk for the society of man. I have no doubt that this is due to their appreciation of a nature higher than their own, and the feeling that their own nature is purified and elevated by contact with man. Indeed, it is a fact that, whenever man and beast are brought into contact, those which possess natures capable of elevation and development cleave to him, court him, and thrive by his presence; whereas those which are incapable of improvement perish before his presence.

It is the same with the human race. When civilized man comes in contact with a barbarian, the latter rapidly tends toward civilization, throws off his barbarian customs, adopts those of the superior being, learns by degrees his arts and sciences, and so gradually merges into civilization. With the savage the case is different. He can not learn any thing good fiom the higher race. He may, and does, gain means by which to derelop more completely his evil tendencies, but is utterly incapable of improvement. He can neither replenish the earth nor subdue it, and so he perishes before the presence of those who do, at all events, endearor to carry out that which is the great mission of man. Wherever civilized man sets his foot, the savage dies out.

Why this is we can not say; but it is a fact long familiar to anthropologists. The Tasmanians have all gone. I have portraits of the last three survivors, all of whom have since died. But the 
strange thing is that the race has died out for want of new births, not because it was extirpated by slaughter. For years before that final extinetion of the Tasmanians, no children were born.

A similar phenomenon, though slower in its operation, is now to be seen in New Zealand. The native race, splendid speeimens of the savage as they are, become yearly fewer and fewer in the presenee of the European, the births falling far short of the deaths. Even in the regetable world the same idea is earried out, and

' the grand tree-ferms, as large as our oaks, are perishing before the advance of the English clover. The lower ereation, if it ean not be elevated by the presenee of the higher, dies out, and the same rule holds good with man, with beast, and with plant.

The next division of the subjeet shows how intense must be the love of animals to man, when the deprivation of the object of their affection has killed them. We sometimes hear of human beings dying from a similar cause, and none of us who heard that a man or woman had died from grief at the loss of a friend would think for a moment that such intensity of love could proeeed from any other souree than the spirit.

Lastly, we have cases where animals, not usually made the eompanions of man, have, unsought, conceived a deep affection for human beings, and have cherished that love in spite of negleet, indifference, dislike, and violence. Such a love is utterly unselfish, and must issue from the same souree that causes man to abandon the love of self for the love of others. It is, in faet, loving the neighbor better than one's self. 


\section{CHAPTER XV.}

\section{CONJUGAL LOV́E.}

Necessary Limits of Conjugal Love among Animals._Non-pairing Animals.-Polygamons Animals._Animals which Pair for a Season._Animals which Pair for Life._Supply of Spare Partners._The Turtledove, the Eagle, and the Raven._Conjugal Love in the Teal._Picture of the "Widow."-Conjugal Love among Fishes.-The "Devil-fish" and its Fate.-The Chocollito of South America.-Faithlessuess, Sorrow, and Death.-Materials for Drama.

As may easily be imagined, there are but few animals in which this kind of love can be manifested. 'The greater number of species have no particular mates, but simply meet almost by chance, and never trouble themselves about each other again. No real conjugal love, therefore, can exist, and it is rather curious that in such animals a firm friendship is often formed between two individuals of the same sex.

Next we come to polygamous animals, such as the stag among mammals and the domestic poultry among birds. Here is a decided advance toward conjugal love, although, as in the case of polygamous man, that love must necessarily be of a very inferior character. Here is, at all events, a sense of appropriation on either side, and, as lias been already mentioned in the chapter headed "Jealousy," the proprietor" of the harem resents any attempt on the part of another male to infringe on lis privileges.

Next we come to those examples where, as in many birds, a couple are mated for the nestingseason, but do not afterward seem to care more for each other than for their broods of children. If, during the nesting-time, one of the pair be killed, the survivor, after brief lamentation, consoles itself in a few hours with another partner. There really seems to be a supply of spare partners of both sexes always at hand; for, whether the slain bird be male or female, one of the same sex is sure to be ready to take its place.

Lastly, we come to those creatures which are mated for life, and among them we often find as sincere conjugal lore as among monogamons mankind. Prominent among them are the eagle, the raven, and the dove; and it is remarkable that while we praise for its conjugal fidelity the turtle-dove, the type of all that is sweet, good, and gentle, we entirely forget to accredit with the same virtue the eagle and the raren, types of all that is violent, dark, and cumning. There are many anecdotes in existence of the conjugal love among such birds, but, as they are so well known, I shall not refer to them, and only mention one or two with which we are not so familiar.

I shall give only three instances, all of which show how deeply conjugal affection can be felt by the lower animals, and how completely the love of self is forgotten in the love of the partner. In the first of these instances, life was risked in the face of danger, and only spared by reason of forbearance; in the second, life was risked and lost; and in the third life was lost without the intervention of any external danger.

In Hardwicke's Science Gossip for 1870, p. 36, there is an account of the teal, in which the conjugal love displayed by this bird is well shown. The writer had been duck-slooting, and had just shot a mallard, when a couple of teal sprang up, alarmed at the report.

"The duck, being the nearest, received the contents of the remaining barrel, and fell dead upon the soft mud at the very edge of the water. "While speculating upon our good lnck, and putting in two fresh cartridges, the cock teal, which had flown up to the other end of the pool when lis mate fell, turned back, and, after flying up and down sereral times with mominful notes, returned to the spot whence he rose, and pitched upon the mud, close to the dead duck. Here he remained for some seconds, nodding his head and courtesying, as if about to take wing, uttering a low note the while, as if to entice away the duck, whom lie appeared so loth to leave.

"We were so struck at this manifestation of affection that we could not find it in onl heart to shoot the poor bird; and, as we moved on to pick up his mate, he rose, and was soon out of range again."

Perhaps the reader may remember a beantiful painting by Landseer, entitled "The Widow," in which a similar scene is represented, except that 
it is the drake which is lying dead, and the duck whieh is mourning over her deceased partner.

Fishes are thought to be rather prosaic beings. They do not possess much expression of feature, at all events, to lumman eyes; and their habits and their looks are, as a rule, much on a par. Yet there is at least one instance known in which a fish, and that a singularly lideous one, exhibited a degree of conjugal love whieh would have done honor to any luman being.

Inhabiting the waters of the Mediterranean Sea is a gigantie ray, ealled popularly the Derilfish, and scientifieally Cephaloptera Massena. 'These fishes are formed much like our eommon ray, but attain the most enormous dimensions, sometimes measuring thirty feet across the fins. 'The power of this fish is quite proportioned to its size. When piereed with eight or ten harpoons, and towing behind it a string of as many boats, all pulling against it, the devil-fish has been known to drag the whole line some ten miles to sea, and finally to break lose and escape, with all the weapons still sticking in its back.

The Mediterranean fishermen employ in the eaptnre of the tminny a vast net, called a mandrague, which is separated into many ehambers. In one of these nets a female devil-fish eontrived to entangle herself, was captured and taken ashore. She weighed 1328 lbs. A male who had accompanied her, but had not got into the net, was discousolate at her capture, and for two days haunted the spot where his eompanion had been captured. He wandered round and round the nets, seeking for his lost mate, and was at last found in the mandrague, but dead, having died of grief.

The last ease is that of some little South American parrots, called Chocollitos. 'They are charming little birds, gentle, and easily tamed. 'They are anong the monogamous birds, and are, as a rule, strictly faithful to their marriage rows. There are, however, exceptions to most rules, and one of these is related by Froebel, in his work on South America.

The traveler in question was a guest for a while in a lionse at Granada. In this house about twenty ehoeollitos were kept; and, as they were all brought to the house when very young, they did not form their matrimonial attachments until after their arrival. Perhaps among them the sexes were not equally divided, so as to insure each bird a mate; but the sad fact was that, after one pair had entered the marriage state, another male made love to the wife. 'The lady was weak, and yielded to the solicitations of the too fascinating lover.

The result was, aeeording to Froebel's own words, as follows: "When the husband understood the whole extent of lis misfortune, and after he lad made the last unsuccessful attempt to bring liis faithless eompanion back to the path of duty, the unlappy creature, heart-broken by his wrongs, took his lonely seat on the pereh on which he had passed happier nights, elosely pressed to the side of his partner, refused to eat or drink, and one morning was found dead on the floor below."

The reader may eompare this narrative with that of the Mandarin duck, narrated on page 94. In both cases there was strong conjugal lore; but in the former the lady was faithful, and her husband avenged limself on the disturber of his domestic peace; while in the latter the lady was frail, and the husband died of a broken heart. Both narratives are wonderfully human, and eaeh eould furnish the plots of a sensational drama. 


\title{
CHAPTER XVI.
}

\author{
PARENTAL LOVE.
}

Absence of Filial Love among Animals. - Analogy with Human Beings.-The Sarage and his Parents.-Parent. al Love among Animals. -The "Storgë" of Theorists.-Identity of the Feeling in Animals and Man. -Endurance of Parental Love in Animals.-Exceptions to the General Rule.-A Cat and Two Generations of Kittens. - My own Cat and her Young._The Dog "Georgie " and her Daughter.-Abnegation of Self.-The Fly-catcher and my Cat.-A Released Prisoner and Joyous Escape._A Courageous Swallow.Redbreast and Viper._-Passive Courage iu a Partridge.-The Whale and her Young.-A Duck's Journey, and Rescue of her Young._Do Animals have Names in their own Language?_The Mystery of Parental Love in Birds._Love and Intellect._Parental Love among Fishes._The Stickleback and its Nest._Apparent Reversion of Parental Love.-The Pipe-fishes and Sea-horses. - The Cursorial Birds and their Eggs. - A Brave Spider._Comparison between Man and Animals.

BEFone beginning this subject, I can not but remark the apparently singular fact that, whereas among the lower animals we find so many instances of the love of parents toward their offspring, we see so few, if, indeed, any trustworthy aeeounts of the Filial Lore, or love of children toward their parents. Yet the same analogy prevails in this as in other cases which have already come before us, and we must look to man if we wish to understand the lower animals. Eren human nature must be highly developed before filial love can find any plaee in the affections. In the savages it barely exists at all, and certainly does not survive into mature years.

Take, for ęxample, even such fine specimens of the savage as the North American Indian and the Fijian. The idea of being subject to their parents never enters their heads; still less does the idea of loving them. It is the glory of a North American Indian boy, at as early an age as possible, to despise his mother and defy his father. And the women are just as bad as the men. They, rejoicing in the pride of youth and strength, utterly despise the elder and feeble women, even though they be their own mothers, and will tear ont of their hands the food which they are abont to eat, on the plea that old women are of no use, and that the food will be much better employed in nourishing the young and the strong.

Then, if the tribe be on the move, and those who are old and infirm are felt to be hinderances, they settle the matter by leaving them behind. They just salve their consciences by building a slight shelter of sticks and boughs, lighting a fire, and leaving a little water and food. But they know perfectly well that before another sun has set there will be nothing left of their vietims but the bones, the wolves having made short work of them as soon as the tribe was out of sight. The forsaken make no complaints, neither do those who press forward expect a better fate; and hence it is that they all wish rather to fall in battle than to die a natural death, after feeling themselves a burden to all around them.

The charming little episode in "Robinson Crusoe," where Friday finds and rejoices over his father, is a very pretty piece of writing, but quite out of aceordanee with the repulsive reality of savage life.

As to the Fijians, they have not the least scruple in burying a fither alive when he begins to be infirm, and assist in strangling a mother so that she may keep lim company. With regard ta the Bosjesinen of South Africa and the "black fellows" of Australia, I very much doubt whether they ever have possessed the least idea that any duty was owing to a parent from a child. Nor have they much notion of duty from a parent toward the child. The father is just as likely as not to murder his child as soon as it is bornperhaps rather more likely than not; and if he be angry with any one for any reason, he has a way of relieving his feelings by driving his spear through his wife or child, whicherer happens to be nearest.

Eren the mother treats her child rather worse than a cow treats her calf, and leaves the tiny creature to shift for itself at an age when the children of civilized parents can scarcely be trusted to pass a quarter of an hour alone.

This being the case with parental love, it may be easily imagined that filial affection can hare but little opportunity of development, and I very 
much donbt whether in the true savage it really exists at all in the sense in which we muderstand it.

$\Delta \mathrm{s}$, therefore, we find that in the lower luman raees filial love either is very trifling, or is absolutely non-existent, we need not wonder that in the lower animals we find but few, if any, indieations of its presence.

We now proeed to the subject of this chapter, namely, PARENTAL LOVE, and the various modes in whieh it develops itself.

There are many writers who assert that parental love in the lower animals is not identical with that of man. They say that it is only a sort of blind instinet, and, in order to mark more strongly the distinction between man and beast, call the parental love of the lattcr by the name of "storgë." For myself, I really fail to see any distinction between the two, except that in civilized min the parental love is better regulated than among the lower animals. But, as we have already seen, among the nuncivilized races it is not regulated at all, and, indecd, many of the beasts are far better parents than most savages.

Neither can I understand why the word "storge" " should be applied to parental love among the lower animals, and not to the same feeling in man. 'The word is used by Greek writers, together with the rerb from which it is formed, to signify the love between human parents and children. For example, in Plato we have the term used for mutnal love between parents and children-" The child loves, and is loved by its parents;" and the same word is used in the same sense in several passages of Sophocles and other writers.

One argument which is always employed by those who deny the identity of the feeling in both cases is that parental love endures throughout life in man, while in the lower animals it expires with the adolescence of the young. This statement is partly, bnt not entircly, true. As a rule, it is true with eivilizcd man; but, as I have already shown, the parental love of a savage docs not last longer than that of a bird, a eat, or a dog, taking into consideration the relative duration of life. And the reason is the same in both cases. Were parental love to exist through life in the savage, the bird, or the beast, the race would soon become extinet. Neither is able to support their children longer than their time of helplessncss. 'The beast and the bird can not, and the savage will not, provide for the future; and if the young had to depend upon their parcnts for subsistenee, they wonld soon perish of lnumger.
There are, however, exeeptions to this general rule, and always, as far as I ean see, in domesticated animals whose means of subsistence are already insured. Several of sueh eases have lately come before my notice. One has been already narrated nnder a different heading, $i, e$, "Sympathy," p. 110, where some traits of two cats, a mother and daughter, are recorded. I here present the reader with another anecdote of parental love surviving adoleseenee. It is a very remarkable story, because we see, in the first place. the usual law prevailing, and the onee-favorite child driven away in anticipation of a new family. That fimily having perished, the original parental love resumed its sway, and the very child which she had angrily expelled from her presence was recalled, and all the treasures of her maternal tenderness poured out upon him:

"A cat, long an inmate of this house, kittened this spring, and one of her offspring, a Tom, being given her to rear, she proved a most fond and solicitons mother. The kitten grew and throve, and soon became a rery fine and playful young eat. The maternal feelings were constantly developed, the mother calling it, licking it, sharing and promoting its frolics, and exhibiting the tenderest anxiety and jealousy whenever any stringe person approached.

"In the midst of this exuberant affection a change passed over the cat, and the young one suddenly became the object of hate and irritation to the formerly loving mother. She would not allow it to approach her; and if it only dared to look at her, she would spit and hiss and fly at it, becoming absolutely savage when she found it near her.

"It soon beeame evident that there would be another litter of kittens, and this sndden change of manner was probably instinctive on the part of the eat, who found herself unable to join in the usual gambols.

"One day, however, a second revnlsion of feeling took place: she called her first-born in the most tender and yearning tones, and tried to entice it up-stairs with her. She was so anxious to have her son with her, that she even tried to drag him.llp-stairs by the neek as she used to do when he was a little kitten.

"Two days afterward the seeond family was born, and all of them met a watery death. The cat did not secm to miss or regret her lost young, but took back her first-born in their place. 'Though as large as its mother, it at once resumed all the habits of its infuncy, sneking as it had been accustomed to do. 'The motler licked and caressed it, just as if it had been a new-born kitten, and displayed the greatest anx- 
iety when the postman or any stranger approached. 'The young 'Tom still continues to suck, though he has canght many mice and eaten them.'

A very similar event occurred lately (1873) in my own house. My cat, called by the children "Duckie," hatd a family, ont of which two were saved. 'These grew to be cats, and, in the ordinary course of events, were sent oft' by their mother. In the mean while a new family arrived, but, as we already had three cats in the house, they were at once dismissed from a world in which there was no place for them. Their mother immediately took the two former kittens into favor; and the odkdest thing was that she treated them exactly as if they had been tiny helpless kittens a few dilys old.

Iler conduct reninded me very minch of that which we often see in parents, especially if they live with or near their children. 'They really can not understand that a man of forty or a woman of thirty are any thing more than children, and are greatly discomposed whenerer these elderly children venture to think or act for themselves. It is the same with old servants; and there are many parents of large families who to the old nurse remain "Master' Tommy "or "Miss Emily" to the end of the chapter.

The next anecdote relates to the dog, and shows that in a civilized $\mathrm{dog}$, so to speak, parental affection can endure as in a civilized human being:

"My dog 'Georgie' (short for Georgina) has a danghter, named 'Poppie,' whose father was a collie, she herseff being a retriever. People said that it was not safe to keep a mongrel of that description, but experience has proved the mistake.

"She is now (1873) five years old, and the affection which exists between mother and daughter is really beantiful. They always sit close together, and Georgie playfully pinches her daughter all over. If they have been separated by any chance, the daughter comes up wagging her tail, and then licks her mother's nose and month.

"Sometimes they go ont rabbit-hunting together, and always act in concert. Each of them takes an opposite side of a whin-bush, and one keeps watch while the other scrapes. They perfectly comprehend the mieaning of each whine or bark, and no two ladies could understand their own langmage better than did these dogs, or be more companionable to ench other."

Here is also another proof of the fact that animals have a language of their own by means of which they can convey definite ideas to each oth- er, nearly if not quite as well as we can do with the aid of words.

One of the most beantiful characteristics of parental love is the utter abnegation of self which it gives. 'This is chiefly shown when the young are in danger. A human mother in charge of her child will defy a danger before which she would shrink if alone, and in defense of her offspring will dare deeds of which most strong men would be incapable. For the time her selfhood is extinguished, and her very being is merged into that of the child; and rather than a hair of that child's head shonlel be touched, she would calmly consent to endure the worst tortures that could be inflicted upon her. Indeed, if she would not do so, she would be no true mother, and wonld degrade herself below the beasts and the birds, who have no hesitation in performing that duty to their offspring, though savans do say that they only possess "storgë," whatever they may mean by it, and not parental love. I will now give a few instances of the marvelous courage inspired by parental love in the lower animals.

Every one who has paid even a passing attention to the habits of birds must have noticed that the spotted fly-catcher has a liabit of selecting some favorite perch, which it frequents from day to day, scarcely ever changing its haunts. From its coign of vantage it keeps anxions watch around, and when it sees an insect on the wing, dashes off, captures it, and returns with its prey to its perch. It may possibly catch insects when they are not on the wing, but I never knew a fly-catcher do so.

In my garden there is a young mulberry-tree, which is highly prized, having been sent specially from Japan, and being the only survivor of six, the others being all killed by nocturnal cats, who found the stems exactly suitable for sharpening their claws. Of course the young tree was watched with exceeding care, and it was soon seen to become the favorite perch of a spotted fly-catcher.

The bird followed the usual customs of its kin, but after a while it began to act in a very strange manner, fluttering backward and forward between the house and the tree, chirping in a lond and distressed tone, and evidently possessed by anger as well as fear. The cause of its extraordinary action was soon seen to be a cat, which was crouching in front of the ventilation-aperture of the ground-floor, and apparently watching something behind the bars. The bird trierl in vain to draw off the cat's attention, fluttering so closely that I feared lest pussy should strike 
it down, and even at times pecking at the animal's tail.

On removing the cat, a young bird was seen within the grating, evidently the offspring of the fly-catcher. These birds have a way of building their nests in very odd places, and I surmise that in the present case the parents must have made thcir way through a hole under the steps, and so have reached the ventilating-shaft.

As soon as the cat had been removed, the inother-bird, regardless of my presence, flew to the grating and began to feed the young one. She then went off to a little distance and called her offspring. The poor little bird did all in its power to get through the bars, fluttering its wings and answering its mother with piteous chirps. I felt quite uneasy about them both, for the cat was sure to come back again, and the mother was so bold and reckless in her assaults that I feared for her life; and if she had been killed, the young one must have died of hunger.

So I tried to see if the young bird was sufficiently fledged to use its wings, as in that case it miglit be let out ; but it was so timid that it retreated into the darkness as soon as I approached, and would not let me examine it. An operaglass, howerer, overcame the difficulty, and, finding that the young bird was fully fledged, I cut away one of the bars so as to leave a passage, and went to some little distance.

The mother, who was anxiously watching me from the roof of an outbuilding, went at once to the spot, and, after much calling, induced her offspring to come out of the aperture which had been made for it. The delight of the two was beautiful to see; but the mother eridently had the cat in her mind, and did not mean to waste any time in placing her child in safety. So she induced it by degrees to follow her up the branches of an apricot-tree, and thence to the roof of the house, where even a cat conld not follow.

In his "Birds of Ireland," vol. i., page 115, Thonipson relates an aneclote of a spotted flycatcher. It had chosen for its resting-place the unglazed window of an onthouse at Beechmount, and had there built a nest, "which was so composed of cobwebs inside and ontside that no other material was visible. From its choice of this fragile building substance, the spotted fly-catcher is called 'cobweb-bird' in some parts of England. On the nest alluded to being approached, when it contained young, the parent-bird was very bold, flying angrily at the intruder, uttering shrill cries, and approaching him so ncar that it might have almost bcen struck with his hand."

The same writer mentions that the spotted flycatcher is equally bold toward other birds, beating a way all which dare to approach their nest. It is perhaps worthy of notice that, in the instance which I myself observed, I did not once sec the male bircl; possibly he may have fallen a viction to the cat.

The swallow is equally courageons in defense of her nest. Some little time ago there was a swallow's nest in the porch of the rectory at Adisham - the bird bcing, of course, carefully protected. Not knowing of the nest, I happened to be standing llear the porch, and was much annoyed by a swallow, which persisted in flying round and round, uttcring its shill, screaming cries, and occasionally darting close to my face. It was not until some little time had elapsed that I suspected the cause of the bird's behavior, and then, on looking around, saw the nest and the young in an angle of the porch.

In all these cases the bird had no hesitation in matching itself against foes from which it would have shrunk in terror had not the love of offspring overpowered the love of life. It does not in the least matter what the foe may be, the parent attacking the most powerful enemy with as little hesitation as if the relative proportions of size and strength were reversed. A snake, for ixample, is specially feared by birds, especially if it be a venomous one; and yet, if a snake threaten the nest of a bird, she will not hesitate to attack as fierccly as if the poison-fangs belonged to her, and not to her foe. 'The following account, published in the Dumfries Courier, 1853, shows how completely parental love will overcome fear, and will induce a feeble bird to fiercely attack a creature from which she wonld have fled but for the supreme power of love :

"While Mr. Charles Newall, granite-hewer in Dalbeattie, was plying his vocation at Craignar quarry, his attention was suddenly arrested by cries strongly indicative of distress, proceeding from one or other of the feathered denizens of the wood.

"On throwing from him his tools, and hurrying to the spot whence the sounds procceded, he discovered a robin, apparently in a state of the greatest agitation, whose morements immediately certified him of the true cause of alarm. An adder, twenty inches long and one inch in circumference, had managed to drag itself up the face of the quarry, and was at that moment in the very act of protruding its ngly head over the edge of a nest, built among the stumps of cut-down bushwood, which contained poor Mother Robin's fledgcel offspring.

" $\mathrm{Hcl}$ matermal instinct prompted her to the only defense of which she was capable. She was 
engaged, when Mr. Newall first got lis eye on lier, in alternately coming down, the one moment upon her spoliator, darting her beak into its foreliead, and anon rising on the wing to the height of a yard or so above the scene of danger. It was the act of a moment for $\mathrm{Mr}$. Newall to dislodge the aggressor; but in doing so two of the little birds were thrown out of their nest, where, howerer, they were speedily and carefully replaced.

"While Mr. Newall was engaged in killing the adder, the joy of the parent-bird was so excessive that she actually perched on the left arm of her lenefactor, and watched with an unmistakable and intense delight every blow inflicted by his right arm upon her merciless and disappointed enemy; and when thit enemy was dead, she alighted upon and pecked the lifeless trunk with all her vigor. Revcuge thus taken, she entered her nest, and, having ascertained that all was safe, swiftly repaired to a neighboring branch and piped, as best she could, what was no doubt meant for a hymn of gratitude and a song of trimmph.

"When at work since, Mr. Newall has been evidently recognized by the tiny biped; and we do hope that nothing may occur to interrupt a friendship originating in circumstances so specially interesting."

In this account we have several characteristics comuron to man and the lower animals. First, there is parental affection; next there is courage emanating from that effect; then there is reason, which told the bird that the man, whom it would liave regarded as an encmy but for his attack on the snake, was really a friend; lastly, there is rerenge, infucing"the bird to peck at the body of its dead foe, just as a savage insults and mutilates the carcass of a slain enemy.

From the description of the snake which is here given, it is tolerably evident that the reptile was a viper, those creatures having a special habit of climbing trees and robbing birds of their young. It has often been found by those who have killed vipers that, after receiving the first stroke, the reptilc has opened its mouth and disgorged sevcral young birds, in order to lighten itself and enable it to escape more quickly. The common, larmless snake, sometimes callcd the "grasssnake," mostly contents itsclf with frogs.

The preceding anecdotes show active courage in the parent; but in Hardwicke's Science Gossip for 1879, p. 204, there is an intcresting account of passive courage in a partridge:

"The affection and solicitude of the female partridge for her young is very grent, and instances are frequently scen by the rural naturalist in his rambles. The closeness with which she will sit when about hatching is remarkable. I once found a nest containing seventeen eggrs, on which the fcmale was sitting, and, instead of flying rapidly away when I approached, she allowed me to stroke her glossy head and soft plumage, seeming to appreciate the familiarity. Her confidence gained its reward, as all of the eggs were duly hatched.

"A gentleman in this neighborhood, when jumping across a hedge, alighted with a foot on each side of a partridge-nest, where the female was sitting. 'The affectionate bird did not stir, eren allowing the gentleman to stroke and fondle her. But more admirable still is the address with which both male and female will draw the spectator away from the neighborhood of their brood. Last July, when walking along the highway, I disturbed two partridges near some tall grass. With startled cries they whirred away; and, alighting a few yards off in the middle of the roak, went through a series of manœurres, as if desperately wounded, both of them groveling along on their bellies in the dust, and seeming to tumble over and over in their eagerness. Stopping some distance off', they began to ntter curious plaintive cries.

"Being somewhat in a hurry, I did not institute a search for the cause of this little drama, the young; but I have seen a similar instance, in which case I captured one of the plump little chicks, and held it for a time in my hands; but the distress of the old bird became so great that I soon rcleased it. In June, 1868 , a pair of partridges lad their nest in the clover ficld opposite, the mowers thouglitfully leaving a tuft of clover to slield the nest. It was very amusing to see how careful the old birds were to prevent attention being drawn to their almost exposed nest. Both of them wonld go in search of food, and then fly back into the field together; alighting within a few yards of the nest, and having anxionsly scanned the neishborhood for a time, the female would slyly approach in a crouching attitude, and creep into the nest."

The proverbial skill of the lapwing in feigning lameness is too familiar to need description.

It is, perhaps, scarcely necessary to cite here the shamefully cruel plan that was formerly used by whalers to secure their prey. If they met with a young whale, or "calf," as they callcd it, they always used to harpoon it, knowing that its mother would come to its rescue, and be so regardless of her own safety that there was neither difficulty nor danger in harpooning her also.

I believe that this atrocious custom is now aban- 
doned, thongh I fear from commercial rather remain there while she pulled them throngli one than conseientions motives. The culf is all but by one.

useless; whereas, if it were allowed to live, it It really seens, in this as in many other inwonld grow into a whale, and fill sundry barrels that would otherwise have to go home empty. The fact, however, remaius that the whale is so ntterly forgetful of self, when its offepring is in danger, that it neglects its nsmal wary habits, and so falls a viction to parental affection.

The following eurions story of parental affection was cominunicated to me by a lady expressly for this work:

"Some years ago (in 1868) our steward and his wife lived in the lorlge at our east gate, distant about half a mile from the house. As a fatvor, the steward's wife allowed a common duck to sit upon a number of duck's eggs, whieh, according to agreement, were to be taken away as soon as they were hatched. In due time the eggs were hatched, and the young ducklings removed to our honse, and placed in the poultry-yard, under the charge of a hen who had already a few dneklings to look ifter. The yard in question is protected by a wall nearly three feet high, and upon this wall is a wire nettiug seven feet in height.

"In the afternoon of the same day the mother duck (who had never left the lodge in her life) came waddling up all the way to the stables, got on the top of the wall, and managed to get her own little ducklings throngh the wire netting. Having done this, she took them back to the lodge, leaving the hen in quiet possession of the ducklings of which she previonsly liad charge.

"As soon as this was known, the ducklings were again taken to the honse, and the duck slut up in a dark place at the lodge for two days. But no sooner did she gain her liberty than she made another jouruey to the poultryyard, and again began to drag her oftspring through the wire net, this time killing one by letting it fall off the dike. I therefore bought the duek from her owner, placed her in the poultry-yard, and allowed her to bring up her brood peacefully in her own way."

How did this duck find ont her young? I imagine that it must have been by the sense of hearing. 1)ncklings, when separated from their mother, or when lost, always make a considerable outcry. The mother duck had probably heard them erying, had gone off in the same direction, and when she got near the poultry-yard had been directed by their voices. It is, moreover, erident that both the mother and the children must have understood each otler's language, as by no other means could she have called her young brood to the fence, and directed them to stances, as if, in their own langunge, the animals lad names known to thenselves, and the Robin, Dicky, Flapsy, and l'ecksy of fietion to be not so much fietitious as we might fancy. In feeding their young, birds always take them in their proper turn, and low they can do so without some means of ealling them by name, especially in the case of birds which hatch many eggs in each brood, is more than I can understand. Botl birds and animals know and answe: to names given to them by man in human langnage, and I see no reason why they should not equally know and answer to names giren by themselves in their own language.

I may here mention that the love of a birk for the young which she hatches has always been somewhat of a problem to me. In the ease of the maminalia, there is no difficulty in understanding that the mother should feel love for the creature who is absolutely part of herself -whose very life-blood is drawn from her veins. But this is not necessarily the case with birds. If, as it often happens with poultry, the eggs of sereral hens are placed under one bird for hateling, the hen who hatches them knows no difference between the chickens that proceed from her own eggs and those which are dereloped from the eggs laid by others.

This emrions trait of character holds good cren where the eggs belong to birds of different species. 'Iake, for example, the rery common instance of a brood of dncklings being hatched and reared by a barn-door hen. 'The hen displays as much affection for the young dnelings as if they had proceeded from her own eggs, and this in spite of the disparity of instinct and habit, which beeomes stronger in proportion to the ducklings' growth.

May it not be that parental love may have different ehamels of transmission, and that in such a case as this the emanation from the sittiug lien may be the velicle of parental love toward the young which are to be hatched? Certain it is to those who observe that a sitting len is altogether a changed being, both in attitude and expression. She is entirely absorbed in the eggs which she is incubating, and, though she may not have intellect enough to distinguish a plaster of-paris imitation or a mere lump of chatk from one of her owl eggs, love is independent of iutelleet, and ma exist in all it: strength, thongh it may be wasted on an unwortlyy object. 
As I have already remarked, under the heading of "Conjugal Lore," fishes are not particularly emotional beings, and are not likely to entertain a lasting love for any thing. Indeed, in some cases parental love would be absolutely useless, as in the case of the cod-fish, which could hardly be expected to entertain a special love for each of the comntless thousands of young which it produces every year. At least, if such were the lot of the mother, her life would be any thing but enviable, considering the varied foes that beset her eggs as soon as they are produced, and her young as soon as they are hatclied.

Just, lowerer, as there are fishes which possess conjugal love, so there are fishes which possess parental love, and the chief of these is the stickleback. Many accounts have been written of the proceedings of this remarkable fish, but the best that I have seen was written by the late J. Keast Lord, in his "Naturalist in British Columbia." And the eurious point is that parental love in the case of the stickleback belongs to the father, and not to the mother. Indeed, as there is one father and a considerable number of mothers, it is the only arrangement that could be made.

Inverting the usual order of things, the whole labor of providing for the young, which is very considerable, devolves upon the male, the female doing nothing except lay her eggs, and let the male look after them.

Mr. Lord's description of his proceedings must be given in his own words :

"I have often, when tired, lain down on the hank of a stream beneath the friendly shade of some leafy tree; and, gazing into its depths, watched the sticklebacks either guarding their nests already built or busy in their construction. 'The site is generally among the stems of aquatic plants, where the water always flows, but not too swiftly. He first begins by carrying small bits of green material, which he nips off the stalks, and tugs from out of the bottom and sides of the banks. These lie attaches by some glutinous material, that he clearly has the power of secreting, to the different stems destined as pillars for his building.

"During this operation he swims against the work already done, splashes about, and seems to test its durability and strength; rubs himself against the tiny kind of platform, scrapes the sliny mucus from his sides to mix with and act as mortar for lis vegetable bricks. 'Then he thrusts his nose into the sand at the bottom, and, bringing a mouthful, scatters it over the foundation. 'This is repeated until enough has been thrown on to weight the slender fabric down, and give it substance and stability. Then more twists, turns, and splashings, to test the firm adherence of all the materials that are intended to constitute the foundation of the house that has yet to be erected on it.

"The nest, or nursery, when completed, is a hollow, somewhat rounded, barrel-shaped structure, worked together much in the same way as the platform fistened to the water-plants; the whole firmly glued together by the viscons secretion scraped from the body. The inside is made as smooth as possible by a kind of plastering system ; the little architect continually goes in, then, turning round and round, works the mucus from his body onto the inner sides of the nest, where it hardens like a tough varnish. There are two apertures, smooth and symmetiical as the hole leading into a wren's nest, and not unlike it."

I have seen plenty of these little nests, and always regretted the extreme difficulty of preserving sucl beautiful specimens of fish-architecture. Unfortmately, although they answer very well as long as they are under water, they do not hold together when removed in to the air, the peculiar cement not being sufficiently strong to bear the unsupported weight of the inaterials.

Having thus prepared his house, the fish sets off in search of a partner to grace it. 'This she does but for a very short time, simply passing in at one aperture and out at the other, remaining some fire minutes in the nest, and luring that time depositing her eggs. Having finished, she passes out, followed by the male, who goes and brings another female, and repeats this process until the nest is furnished with as many eggs as it can hold.

He then places himself on guard, and watches his treasure as vigilantly and fiercely as a tigress watches her cubs. He often has to fight hard battles, for there is no delicacy so loved by fish as the roe of other fish, even of their own species; and the nest is sure to be beset by sticklebacks or other fish. and water-beetles, trying to get at the eggs. For some six weeks he keeps this anxious watch, and even when the young are hatched he does not desert his post. It is said that he will not allow them to wander far from the nest, and that if one of them should stray beyond certain limits, lle will seize it and bring it back again.

In the encounters which he has to undertake he rums much risk of losing lis life, for the sharp spines with which the body is armed are weapons which can be used with fatal dexterity. Each fish tries to force its way under the other, and, if it can succeed, rises rapidly, and drives the 
spines into the sides or belly of its adversary, often calusing its death, and ulways wounding it seriously. Even in fishes, then, we see parental love sufficiently developed to induce the male sticklebaek to remain for six weeks on guard, to fight any foe that may attempt to rob him of his treasure, and to risk and sometimes to lose his life in the defense of his offspring.

The reader will not fail to have noted the curious fact that, whereas parental love is, in nearly all creatures, ehiefly manifested in the mother, in this ease the mother never troubles herself about the fate of the eggs whieh she has deposited, but leaves them all to the father. Neither does she take any share in the preparation of the nest, the whole of the labor belonging to the male, who has to gather materials, make the nest, get it stoeked with eggs, guird it at the risk of lis life, and see the ycung safely started in life. 'The human parallel is too obrious to need mention.

There are other fishes in which the male takes the ehief part in the incubation of the eggs. Such, for example, are the eurious Lophobranehiate fishes, of which the common bill-fish, or pipe-fish, and the quaint little sea-horse are good examples. The former, by the way, is mueh more plentiful than is generally supposed, and I have found many of them served up among the tiny fishes which are ealled by the general name of whitebait. In all these fishes the males are provided with some special apparatus, such as a poueh, a double ridge of skin, ete, by means of whieh the eggrs are attached to the body of the male until they are hatehed.

Then there are certain birds, mostly belonging to the Cursoria, or that group of which the ostrieh is the type, the females of which take no trouble about their eggs after laying them, but depute the whole of that business to their mates.

An instance where a spider defended its eggs against most formidable enemies is narrated by Mr. F. C. Rawlins in Hardricke's Science Grossip for April, 1873.

In a recent number I saw some interesting matter relative to spiders and their poisoning apparatus. The following, which comes from personal observation, will vouch for the efficaey of this apparatus, and also show what a weapon of defense it beeomes when the parental instinet is roused by an attaek upon the offspring:

"One day in the autumn I captured a fine speeimen of the garden spider (Epeira diadema), which was running over a flower border, skillfully eonveying the precious filmy bag of eggs nulderneatl its body over the varions obstacles which impeded its progress. It did not seem averse to the shelter afforded by a small wooden box, and remained at one end with its treasure so eontentecily that I left it for a few moments, and placed it on the top of a dahlia-pole.

"On returning I discovered that an exploring party, consisting of four ants, was senhing the walls of the fortress. Until they were fairly within its walls the spider seemed unaware of their approaelı; and, in fuet, until a forcible attempt was made by the intruders to grapple with the egg-bang, it remained strangely apathetic. But this insult offered to the helpless young was too mueh. It darted forward and assailed the foremost. It was a tougl fight-four to onebut the valiant mother conquered in the end; for three of the invading foe lay dead (evidently poisoned by a venomous bite), and the fourth was fairly driven off. 'The victor then retired with her insulted property to a eorner, and I carried off the box.

"An untimely escape prevented an experiment I hoped to make, viz., of trying to tame this member of the usually disliked Araehnida family."

It would have been easy enough to fill the whole of the book with stories of true parental love among the lower animals, but I have selected these in order to show that the feeling is identical in man and the lower animals, although, of eourse, the mode of manifesting it must differ. First, we see the untruth of the theory that parental love is life-enduring in man and only brief among the animals. We see that, in proportion to the duration of life, it is quite as brief among the sarages as among the animals. Then we have examples where parental lore has been lost and then restored, and also where it never was lost.

We see how, in the animals as well as in man, parental love causes complete abnegation of self, the parents living for their ehildren, and not for themselves. We see how it gives strength to the weak and courage to the timid; that even the very fishes and the spiders are amenable to the same influences as man, and that parental love, one of the highest and holiest feelings of which a living and immortal soul can be eapable, is shared equally by man and bcast, according to their respective capacities. 


\section{CHAPTER XVII.}

\section{THE FU'TURE STATE.}

Immortality of Man as Treated in the Old Testument.-The Lower Animals not Thought Unworthy of a Divine Law.-Man and Beast Equally Liable to Punishment for the Same Crime.-Instiuctive Belief in Immortality.-The Spirit of Animals Developed by Communion with the Spirit of Man.-_Opinions of Various Writers on the Subject.-Eugenie de Guérin and Mrs. Somerville._The Contemplative and Logical Minds. - Southey's Epitaph on his Dog.-Lamartine on a Similar Subject.-The Doctrine of Apparent Inequality and Compensation.-How to Reconcile Pain and Suffering with Diviue Justice._The Difierent Lots of Man and Berst.-The Object of Suffering.-Individuality connected with Immortality.--Individuality often Overlooked, even though it be Strougly Marked to those who can Detect it.-The Groom and the Euginedriver.-Individuality Retained in the Next World, and Developed there.-Mr. J. Nelson Smith on a Dead Lion.-The Spirit of the Beast; Comparison with that of Man.-Death and its Results in Man and Beast. - Spirit and Matter.-The Dead and the Living._The Spiritual and Material Eye.-The Story of Balaam. -The Cat aud the Apparition. -Parallel of the Two Narratives.-Epilogue.

I HAVE already shown, at the beginning of this work, that, contrary to the popular tradition, the Scriptures do not deny a future life to the lower animals. We will now see if Scripture tr has any thing to say in favor of another world for beast as well as inan.

It is a very remarkable point that even as to the immortality of man, the Scriptures of the Old 'Testament teach that doctrine rather by inferenee than by direct assertion.

I presume the reason to be that the writers of the various books, which were at a comparatively late period selected from among many others and formed into the volume which we popularly call the Bible, assumed as a matter of course that man was immortal, and did not trouble themselves to assert that which they supposed every one to know already.

As far as the Old Testament goes, inferenee tells much stronger in faror of the beast's immortality than in that of man; for although in either ease there is no definite assertion of a future life, there is at all erents no such denial of the immortality of the beast as we have seen to be the case with man (see page 10).

We all know that the beasts were included in the merciful provisions of the Sabbath, which was in its essence a spiritual and not merely a physical ordinance. 'Then we find in the ancient Scriptures many provisions against maltreating the lower animals, or giving them needless pain; and these provisions occupy an equal place in the Divine Law with those which treat of man.

See, for example, the well-known prohibition of "scething a kid in its mother's milk," this being apparently some cruel heathen custom during liarvest-tide. Then the ox which is used in treading ont the corn is not to be muzzled, lest it should suffer the pangs of hunger in the presence of the food which it may not eat. Even such a trivial eustom as bird's-nesting is regulated by Divine Law (see Deut. xxii. 6,7). As, moreover, many animals must be killed daily, some for saerifiee and others only for food, the strictest regulations are given that their mode of death shall be sharp and swift, and that the whole of their blood shinl be poured ont upon the earth, thus preventing them from lingering in pain.

I need scircely refer to the last few sentences of the Book of Jonah:

"Thou hast had pity on the,gourd, for" the which thon hast not labored, neither madest it grow; which came up in a night, and perished in a night :

"And should I not spare Nineveh, that great eity, wherein are more than sixscore thousand persons that ean not discern between their right hand and their left hand; and also much cattle?" Agrain, see Psalm 1. 10,11:

"Every beast of the forest is mine, and the cattle upon a thousand hills.

"I know all the fowls of the mountains: and the wild beasts of the field are mine."

The Seriptures are full of similar passages, in which God annomnces himself as the protector of beast as well as of man; among which we may reckon the well-known saying of our Lord respecting the lives of the sparrows. 
Allusion to this branch of the subject is made ly Cowper in his "Task :"

"Man may dismiss compassion from his heart, But God will never. When He charged the Jew 'To assist his foe's down-fallen beast to rise; And when the bush-exploring boy, that seized The young, to let the parent-bird go free; Proved He nut plainly that His meaner works Are yet His care, and have an interest allAll in the nniversal Father's love."

CowPER's Task.

There is, howerer, one passage which certainly does seem to point to a future fur the beast as well as for man, and does at all events place them both on a similar level. It oecurs in Genesis ix. 5, and forms part of the concise law which was delivered to Noall, and which was the forerumer of the fuller law afterward given through Moses: "Surely your blood of your lives will I require: at the hand of erery beast will I require it, and at the hand of every man; at the hand of every man's brother will I require the life of man."

And this injunction was afterward incorporated into the Mosaic law, where an ox who kills a man is subject to deatl, just as if it had been a man who had murdered one of his fellows (see Exodus xxi. 28).

As a writer in the London Review well said, some years ago: "There would be no meaning in this retribution if the animal had no living soul to be forfeited, as the human sonl had been yielded to death. It would be absurd to destroy a vegetable which had caused the deatl of a human being, inasmuch as it has no soul. It was not considered absurd to destroy an animal under such circumstances, inasmuch as it has a sonl."

'Thus, while there are no passages of Scripture which deny the immortality of the lower animals, there are some which certainly tend toward inferring it; but I do not see how we could expect to gain any information on the subject from the Seriptures, which were written for human beings, and not for the lower animals; and, as we find so fow direct references to the future state of man, we conld hardly expect to receive direct instruction upon that of beists.

But just as man lias always had within himself an intuitive witness to his own immortality, so do I find that all who have watched the ways of the lower animals have possessed an instinctive sense that they too must have a future life. Some, it is true, have been led away by a wrong interpretation of the passages in the l'salms, Job, and Eecclesiastes; but, in conversing with then, I have always found that underying this idea is al feeling that animals, which surpass many hu- man beings in lore, unselfishness, generosity, conscience, and self-sacrifice, must share, tugether with those virtnes, an immortal spirit in which they take their rise.

For my'self, I attribnte to the conduct of my dog "Rory" my firm conviction that for such animals a future life must be in store; and if for him, why not for all? It is true that in him the moral sense of duty was dereloped to a very ligh degree, as were his reasoning powers and the faculty of love. I could not believe that an animal which would die of grief, as he died, for the absence of his master, conkl have his existence limited to this present world, and that such intensity of love should terminate at the same moment that the material heart ceased to beat.

But, though in his case these higher qualities were so greatly developed by constint communion with a luman spirit, there are hundreds of thonsands of dogs with similar capabilities, but witlont similar advantages. I feel sure that they will have the opportunity of developing their latent ficulties in the next world, though their free scope has been denied to them in the short time of their existence in this present world.

I have been rather surprised to find how many standard writers have held these opinions. All students of theology are acquainted with the passage in Bishop Butler's "Analogy" in which he states that the Scriptures give no reasons why the lower animals should not possess immortal souls. I will now take passages by two very celebrated women, the former a representative of devotional religion, and the latter a thorough mistress of the plyysical sciences, and a deep mathematician.

The first extract is talien from the "Diary" of Eugenie de Guérin, and is a remarkable instance of the manner in which the contemplative human soul yearns after companionship with the souls of fellow-creatures that have been loved and have passed away:

"1st August, 1835. - This erening my turtledore has died; I know not from what canse, for it continned to coo up to to-day. Poor little creature, what regret it causes me! I lored it; it was white; and every morning it was the first roice I heard under my window, in winter as well as in summer. Was it mourning or joy? I know not, but its songs gare me pleasure. Now I have a pleasure the less: thus each day we lose sone enjoyment.

"I mean to put my dove under a rose-bush on the terrace: it seems to me that it will be well there, and that its sonl (if soul there be) will repose there sweetly in that nest beneath the flowers. I have a tolerably strong belief in the sonts of 
animals, and I should even like there to be a little paradise for the good and gentle, like turtle-dores, dogs, and lambs. But what to do with wolves and other wicked minds? 'To damn them ? - that $\mathrm{cm}$ barrasses me."

She might have reflected that, in its place, the wolf is as useful and an innocent as the lamb. It has an object in life, and carries it out nntil that object be attained, when it perishes, as has been the case in our own conntry, not only with the wolf, but witl the bear and other predacious animals.

'The next passage is taken from Mrs. Somerville's "Memoirs." I liave selected these two because they represent two differently constituted minds, which yet agree just on the rery subject where one would have expected the greatest divergence.

The one is essentially devotional, trusting to intuitive ideas, and not haring the least pretense to logic, or eren a sequence of reasoning. The other is a mind traincel to observation, to mathematical accuracy, to lard reasoning, and to that faculty which is so seldom seen in the female sex -namely, the power of generalization. Speaking of death, and the accompanying change of surrounding objects, Mrs. Somerville, then aged eiglity-nine, proceeds as follows:

"I shall regret the sky, the sea, with all the changes of their beantiful coloring; the earth, with its rerdure and flowers; but far more shall I grierc to leave animals who have followed our steps affectionately for years, without knowing for certainty their ultimate fite, though I firmly believe that the living principle is never extinguished. Since the atoms of matter are indestructible, as far as we know, it is difficult to believe that the spark which gives to their union life, memory, affection, intelligence, and fidelity is eranescent.

"Every atom in the human frame, as well as in that of animals, mndergoes a periodical change by continual waste and renovation: the abode is changed, not its inhabitant. If animals have no future, the existence of many is most wretched. Multitudes are starved, cruelly beaten, and londed during life; many die under a barbarous vivisection.

"I can not believe that any creature was created for unconpensated misery : it would be contrary to the attribute of God's mercy and justice. I am sincerely happy to find that I am not the only belierer in the immortality of the lower animals."

We will presently revert to the latter part of this interesting letter. I can not but notice the remarkable fact that two minds so differently con- stituted should have arrived at the same result in two different ways. 'The one does not pretend to any process of reason, but passes at once, per saltum as it were, to the firm belief that the lower animals must have a future life. The other works her way to the same point throngh a consecutive train of reasoning, basing her arguments upon physical facts of which Madame de Guérin was entirely ignorant. We instinctively agree with the one, and we can not disagree with the other.

Having now seen the manner in which the contemplative and logical ferrale minds treat this subject, let us turn to the masculine mind. We will take for example Sonthey, a man of singularly deep and wide reading, possessed of the exceptional gift of rencering poetical the least beantiful of subjects. If ever there were a clumsy and repulsive idealization in the world, it may be found in the many-headed and many-armed deities of Hindoo mythology; and ret, in the hands of Southey, they are invested with a glamour like that which Scott threw orer the most prosaic and commonplace of landscapes in his native land.

Writing of the deatlo of a favorite spaniel who had been his companion in boyhood, Southey proceeds as follows:

\section{"Ah, poor companion! when thou followedst last \\ Thy master's parting footsteps to the gate \\ Which closed forever on him, thou didst lose \\ Thy best friend, and none was left to plead \\ For the old age of brute fidelity. \\ But fare thee well. Mine is no narrow creed; And He who gave thee being did not frame \\ The mystery of Life to be the sport \\ of merciless man. There is another world \\ For all that live and move-a better one ! \\ Where the prond bipeds, who wonld fain confine \\ Infinite goodness to the little bounds \\ Of their own charity, may envy thee."}

The following extract is taken from "Jocelyn's Episode, par A. de Lamartine," and is translated by the author" of "Episodes of Insect Life :"

"MIy dog! the difference between thee and me Knows only onr Creator";-only He

Can number the degrees in being's scale

Between thy instinctive lamp, ne'er known to fail, And that less steady light of brighter ray,

The sonl which animates thy master's clay;

And $\mathrm{He}$ alone can tell by what fond tie,

My look thy life-my death, thy sign to clie. Howe'er this be, the human heart bereaved, In thy affection owns a boon received;

Nor e'er, fond creature, prostrate on the ground, Conld my foot spurn thee or my accents wound.

No! never, never, my poor humble frieind, Conld I by act or word thy love offend!

Too much in thee I reverence that Power Which formed us both for our appointed hour; That Hand which links, by a fraternal tie, The meanest of His creatures with the high. Oh, my poor Fido! when thy speaking face, Upturned to mine, of words supplies the place; 
When, seated by my bed, the slightest moan

That breaks my troubled sleep disturbs thine own; When noting in my heavy eye the care

That clouds my brow, thou seek'st its meaning there. And then, as if to chase that care away, My pendant hand dost gently guaw in play ; When, as in some clear mirror, I descry My joys aud griefs reflected in thine eye:

When tokens such as these thy reason speak (Reason which with thy love compared is weak), I can not, will not, deem thee a deceiving, Illnsive mockery of human feeling,

A body organized, by fond caress

Winmed into seeming tenderness; A mere automaton, on which our love

Plays, as on puppets, when their wires we move. No! when that feeling quits thy glazing eye,

'Twill live in some blest world beyond the sky.

No! God will never quench IIis spark divine, Whether within some glorions orb it shine, Or lighten up the spaniel's tender gaze,

Who leads his poor blind master through the maze Of this dark world; and, when that task is o'er, Sleeps on his humble grave, to wake no more."

We will now revert for a time to the subject mentioned at the end of the extract from Mrs. Sonerville's "Memoirs." Every one must at some time or another have been struck with the problem of apparent inequality in the lives both of man and beast. We see some human beings endowed with every thing that man can desire-health, strength, wealth, accomplishments, and capacity of enjoyment; while others are destitute of all these accessories to happiness.

Putting aside the fact that some whose lots seem to be the most enviable are the least to be envied, we acknowledge that this inequality does exist, and that the earthly lot of some is very hard, while that of others is very easy. But we are taught in the New Testament the great doctrine of Compensation, which is, in fact, nothing more than justice.

As St. Panl remarks, who spoke from personal experience, the sufferings of this present world are not to be compared with the glories of the world to come; and that, in fact, suffering is the precursor of glory. 'That some such prineiple of divine justice must exist was instinctively known long before it was thus explicitly declared. We find references to such compensation throughout the Psahms, in passages too nummerons and too fitmiliar to need quotation; and eren Job himself, sunk in the very depth of afflictions, conld say, "Though IIe slay me, yet will I trust in Him. ...He also shall be my salvation" (Job xiii. $15,16)$.

$\Lambda \mathrm{s}$ far, therefore, as man is concerned, the problem of apparent inequality is not so difficult of solntion. Expectant of a future life, we look forward to it in our worst earthly sorrows, and feel that when we have passed into that new life we shall receive our reward. 'Thus, in spite of all apparent inequalities of the human lot in this world, we fecl that divine justice will be more than vindicated in the world to come, and that when we enter that world we shall understand and acquiesce in the justice that gave a hard lot upon earth to us and an easy one to others.

But, supposing the lower animals to have no future life, what becomes of divine justice? Even in our own country and in our own day, the cruelties that are perpetrated upon animals are a disgrace to the nation. Bad as they are, however, they are as nothing to the horror's which are scen with absolute unconcern in other countries. But, eren in our own land, let us take as an example one of the most ill treated of animals-the donkcy.

We will suppose the very likely case of two donkeys of the same age and similar capacities bcing sold to different master's, both costermongers. One of them treats the animal with kindness, and the other with cruelty. The one urges it to its work by kind words, the other by blows and other forms of bodily torture. The one feeds the animal as liberally as his mcans will afford, while the other leares the beast, by whose labor he lives, to forage for himself, and spends in drink the money which ought to have been expended in fodder.

One of these animals lives a long and a happy life, doing his work with eager willingness, loring his master, and being loyed by him. The other is soon worn ont by hardships, trembles at the very sound of his master's voice, and succumbs at last to pain and starvation. I have purposely placed the more farored animal in a laboring sphere of life, because I am sure that it was formed for labor, and that a properly directed life of work is far happier than the state of a petted, pampered, and idle animal.

Now, supposing that animals have no immortal souls and no future life, it is simply impossible to recognize that the Maker of these two animals can be just. The two contrasted lives indicate an injustice too flagrant for any human being to perpctrate unless wholly deficient in ideas of right and wrong. But supposing them to possess immortal souls, and a future life in which those souls shall be developed to the fullest amount of their capacities, then we can at once reconcile those apparent discrepancies with absolute justice and perfect lore. Dealing with the lower animals as with onrselves, the Creator looks to the spiritual world, which is eternal, and not to the material world, which is temporal, and by means of the one instructs and prepares his pupils for the other:

Take the most prominent instance of apparent 
inequality and injustice-namely, porerty and wealth. We are gifted with wealth, or it is withheld from ns, according to our individual capacities. 'That which is good for one, as a preparation for the future life, is bad for another, and it is given or witheld accordingly. For example, we all know that when our Lord met the wealthy young man who was proud of his riches, and yet desired to be a disciple, the condition of admission was that he should divest himself of all his wealth, and divide it among the poor.

Nany persons have inferred from this order that no one ought to possess wealth. But a little reflection will show that the order in question was not universal, but addressed to a single individual, and to no other. 'There were many rich men with whom Christ habitually associated, notably Joseph of Arimathea, and yet he nerer advised them to reduce themselves to porerty.

He knew best what was good for each, and a fortioni must he know what is good for animals which exist on a lower and more contracted plane than man. I firmly believe, with St. Paul, that the object of sutfering in this present world is that it forms a preparation and introduction to the life to come; and I am perfectly convinced that any creature which is capable of suffering has in that very capacity its passport to the eternal life for which its sufferings are but a preparation.

This brings us to another stage in our argument-namely, the possession of Individuality as connected with Immortality.

As for ourselyes, did we not possess individuality we should need no diverseness of management, for all would be treated alike. But we see that in man no two faces are exactly alike, simply becanse no two souls, of which the countenance is an indication, are allike; and the same will hold good among the lower animals.

Looking, for example, at a flock of sheep, there is no apparent difference between them, and a portrait of any one would equally resemble any other. But the shepherd, if he know his business, will be able to distinguish every sheep separately, and can describe the mental peculiarities of each individual.

Again : one yellow canary looks, to ordinary eyes, just like another yellow canary, while in reality the mental character of each bird is inpressed upon its comntenance as strongly as are human qualities upon the risage of man. I once had some thirty canaries in a single ariany, and not only knew them all ly sight, but could anticipate how each bird would act under certain circumstances.
It is this quality, both in man and beast, that implies a separate treatment for each individual, and becomes a plea for immortality. 'That I am not alone in this idea is shown by the following letter from a correspondent :

"The difference in character between individuals of the same species is as striking as the differences among men.

" $\mathrm{My}$ present dog, though rery handsome, is a thorougl rulgarian in mind. He prefers bad company, lives by choice in the kitchen, is rude and ummannerly, never barks at a beggar, and delights in a general row or a fight over a bone.

"My former dog, 'Nettle,' was a perfect aristocrat. Nothing would induee him to consort with vulgar people, to enter a kitchen, or descend the area stairs. He perfectly understood the importance attaehed to a large house and handsome furniture. When we were traveling in the Highlands, and had to put up in any lodgings which we could get, Net tle was perfectly miserable. I remember him at Ballater persistently rushing past onr shabby house into one next door, which was handsomely furnished. The lady in occupation disliked dogs; so, after capturing Nettle once or twiee, when he had made a raid upon our neighbor's premises, we had to watch him when we neared the house, and bring him by force into our mean quarters. At list we secured handsome lodgings; whereupon Nettle's dignity was soothed, and he never mistook his own abode any more.

"These things seem to be trifles, but it is the observation of such apparent trifles in every creature which I have been able to watch carcfully that convinces me more of their separate. individual, spiritual life than even the evidences of great intellect that are occasionally giren. Were the beasts but mere animated machines, these distinctive charaeteristics need not exist."

I may here mention that my own cat "Pret" was equally aristocratic in lis notions. Nothing would induce him-not even milk when he was. hungry - to put his head into the kitchen, or to enter the house by the serrants' door.

'To me, the manner in which we ignore individuality in the lower animals is simply astounding. See, for example, how the generality of grooms treat all horses as if they were just so many machines turned out of the same mould, and to be treated just like machines. The "Go ahead," "Stop her," "Back her," of the engineer are represented by the whip or spur of the groom, the jerk or savage pull at the bridle; and the groom has no more idea that lie is inflicting pain upon the senses of an immortal fellow-creature than has the engineer of hurting 
the iron and brass of his engine. Indeed, I fear that, as a rule, the average driver is more merciful to his engine than the average groom to his horse, the former sparing it at the descents, and helping it up the ascents by the accumulated force obtained by the rush down the preceding decline.

We have thus in every species a double kind of individuality : first there is one that is common to the entire species, and next there is one that, in addition to this common claracteristic, distingnisles each separate being from its fellows. It is the former of these which makes a species to be what it is, and I am firmly convinced that neither is lost in the future life-that both may be capable of clevelopment. Thus, I hold that the dog, the horse, the lion, and the elephant will be in the next world what they atc in this. 'They will be better animals in that world, just as we hope to be better men; but they will not approach us any nearer than they do at present.

I will here quote an eloquent passage from a very remarkable book, which is nearly unknown -namely, "The Science of Sensibility," by $\mathrm{Mr}$. J. Nelson Smith :

"Behold the lion, when he comes forth from his den to seize the prey which his own wants and those of lis whelps demand, with flowing inane, steadfast purpose, and paralyzing gleam of eye. ... If the voice of lightning is fuller in its volume as it peals over the plains, the vibrating death-knell of the lion is more appalling to both man and beast. If the burning ball of electricity is irresistible, the fatal grasp of the lion is no less fatal to animals; if its flash is more vivid, the angry glare of his eve is more terrible to encounter. 'The terror of all beasts, and undisputed monarch of the forest, he roams from jungle to jungle and knows no fear.

"But the skill of the hunter sends a bullet through the organs of thought, judginent, and will in that self-reliant head: one terrific bound, one desperate sweep of those huge paws in a vain effort to tear the earth from its centre, and down goes the carcass of that fearful monach of the forest, stark, by the huge rock on which he has so often ganboled.

"A few spasmodic surges, convulsive tremors, and he stretches himself on the gromnd, an inmorable mass of terrestrial matter. Those gleaming orbs are glazed and sightless, and those terrible limbs are stiffened with the chill of deatl. Still, eren that lifeless frame is an admirulole statue of aninal force and unquestioned comrage, and his slayer approaches even his lifeless corpse with fear, and springs back at the slightest trenor of lis departing life.

"Wliat made lis voice more terrible than thunder, his spring more fatil than its bolt, and where is it gone?

"Since the departure of the soul, the intelligent motive power which was driven out of that musculux structure by the derangement of the machinery of the mind on which it operated and performed those appalling strains in the great drama of life, that terible structure of animal life is as larmless as a marble statue, and is soon decomposed by the chemical elements which surround it.

"For an hour after its departure the carcass remains warm and pliable. Every limb is perfect, not a muscle of the body is injured; only the organ of will is unstrung, and the spiritual operator departed. And such an operator! Is his knowledge obliterated? Has a leaden mis sile annihilated a decree of the Almighty, and deconposed a celestial volition ?-or has it only released an immortal soul from the prison-house of a terrestrial body, and given it a passport to the sublime joy of its eternal existence?"

In the last sentence the writer has tonched upon the central idea of this book-namely, the possession by animals of an immortal soul. 'The reader may remark that at page 14 I have cited the important passage of Ecclesiastes, in which a spirit is assigned to the beasts as well as to man. Now the very fact that man can transmit his ideas to the lower animals is a proof that they must possess a spirit which is able to communicate with the spirit of man. When, for example, a man gives an order to his dog, and is obered, he affords a proof that both possess spirits, similar in quality, thongh differing in degree. To give an order to a plant would be useless and absurd, because the plant has no spirit which can respond to the spirit of the man. But the spirit of the $\log$ can and does respond to the spirit of the man-and the two will equally live, each on its proper plane, after the earthly body has been resolred into its elements.

One of our poets has rightly said-

\section{"Man never dies: the bolly dies from off him ;"}

and this is equally true of man and beast. The change which we call death is but a more rapid disengagement of the spirit from the body than that which is perpetually taking place. The body is unceasingly separating itself from the spirit, and whether in the waking or sleeping hours the earthly particles which the spirit has accreted around itself are constantly being thrown oft. In fact, the death of the body is ever with us, and is a necessary concomitant of the temporary connection between the inmortal spirit and the material world. 
We now adrance one more step.

We all know that spirit can not act directly upon matter, and vice versâ. 'The earthly eye, for example, can not see spiritual objects. Bnit the spiritual eye, which gives force and potency to the optic nerves of the miaterial eye, can do so if the outer reil of flesh be for a while removed. 'Take, for examplc, a ferw instances of such extended vision as given in the Scriptures. First, there is the case of Elisha's servant, whose spiritual eyes were opened, $i$. e., enabled to pierce through the reil of the flesh, and who was enabled to see the hosts of spiritual beings by whom the place was surrounded. Similarly, when the shepherds saw the angels who announced the birth of Christ, and when the three apostles saw Moses and Elijah, they saw these spiritual beings with the eye of the spirit, and not with that of the flesh.

There are, as we know, many persons who can not believe that, as they put it, the living should be able to see the dead. Neither do I believe it. But as the spirit lires, though the material body 110 longer inclose it, surely there can be no difficulty in believing that the living spirit within an earthly body may see a living spirit which has escaped from its matcrial garment. We do not doubt that after the death of the body the spirit will live and sce other spirits similarly freed from earth, and it is no very great matter that the living should see the living, though one be still enshrined in its earthly tabcrnacle, and the other released from it.

This being granted-and it is not very much to grant-it necessarily follows that if the lower animals possess spirit, they may be capable of spiritual as wcll as material vision. That they do possess this power, and that it can be exercised, is shown by the story of Balaam. There we find it definitely stated, not only that the ass saw the angel, but that she saw him long before her master did. Now the angel, being a spiritual being, could only be seen with the spiritual eye; and it therefore follows that, mnless the story be completely false, the animal possessed a spirit, and saw with the eye of that spirit.

I should think that none who believe in the truth of the IIoly Scriptures (and I again remind the reader that this book is only intended for those who do so), conld doubt that here is a case which proves that the spirit of the ass was capable of sceing and fearing the spiritual angel. And if that be granted, I do not see how any one can doubt that the spirit which saw the angel partook of his immortality, just as her outward eye, which saw material objects, partook of their mortality. Shortly afterward the eyes of the prophet were opened, and he also saw the angel; but it must be remembered that the eyes of the beast had been opened first, and that she, her master, and the angel met for the time in the same spiritual plane.

I have for a long time had in $\mathrm{my}$ possession a letter from a lady, in which she narrates a personal adventure which has a singularly close resemblance to the Scriptural story of Balaan. It had been told me immediately after I threw out my "fecler" in the "Common Objects of the Country." $\Lambda$ s I had at that time the intention of vindicating the immortality of the lower animals, I requested the narrator to write it, so that I might possess the statement authenticated in her own handwriting.

At the time of the occurrence, the lady and her mother were living in an old country chatean in France.

"It was during the winter of 18 -- that one evening I happened to be sitting by the side of a cheerful fire in $\mathrm{my}$ bedroom, busily engaged in caressing a farorite cat - the illustrious Lady Catharine, now, alas! no more. She lay in a pensive attitude and a winking state of drowsiness in my lap.

"Although my room might have bcen without candles, it was perfectly illuminated by the light of the fire. 'There were two doors-one behind me, leading into an apartment which had been locked for the winter, and another on the opposite side of the room, which communicated with the passage.

"Mamma had not left me many minutes, and the high-backed, old-fashioned arm-chair, which she had occupied, remained vacant at the opposite corner of the fire-place. Puss, who lay with her liead on my arm, became more and more sleepy, and I pondered on the propriety of preparing for bed.

"Of a sudden I became aware that something had affected my pet's equanimity. The purring ceased, and she exhibited rapidly increasing symptoms of uneasiness. I bent down, and endeavored to coax her into quietness; but she instantly struggled to her feet in iny lap, and, spitting vehemently, with back arched and tail swollen, she assumed a mingled attitude of terror and defiance.

"The change in her position obliged me to raise my head; and on looking up, to my inexpressible horror, I then perceived that a little, hideous, wrinkled old hag occupied mamma's chair. Her hands were rested on her knees, and her body was stooped forward so as to bring her face in close proximity with mine. Her eyes, piercingly fierce and shining with an orer- 
powering lustre, were stcadfastly fixed on me. It was as if a fiend were glaring at me through them. Her dress and general appearance denoted her to belong to the French bourgeoisie; but those eyes, so wonderfully lirge, and in their expression so intensely wicked, entirely absorbed my senses, and precluded any attention to detail. I should have screamed, but my breath was gone while that tertible gaze so horribly fiscinated me: I conld neither withdraw my eyes nor rise from my seat.

"I had meanwhile been trying to keep a tight liold on the cat, but she seemed resolutely determined not to remain in such ngly neighborhood, and, after some most desperiate efforts, at length succeeded in escaping from my grasp. Leaping over tables, chairs, and all that came in her way, she repeatedly threw herself, with frightful violence, against the top panel of the door which communicated with the disused room. 'Then, returning in the same frantic manner, she furiously dashed against the door on the opposite side.

"My terror" was divided, and I looked by turns, now at the old woman, whose great staring eyes were constantly fixed on me, and now at the cat, who was becoming every instant more frantic. At last the dreadful idea that the animal had gone mad had the effect of restoring my breath, and I screamed londly.

"Mamma ran in immediately, and the cat, on the door opening; literally sprang over her head, and for npward of half an hour ran up and down stairs as if pursued. I turned to point to the object of my terror: it was gone. Under such circunstances the lapse of time is difficult to appreciate, but I shonld think that the apparition lasted about four or five minutes.

"Some time afterward it transpired that a former proprietor of the house, a woman, had hanged herself in that rery room."

The close but eridently unsuspected rescmblance of this narrative to the story of Balaam is worthy of notice. In both cases we have the remarkable fact that the animal was the first to see the spiritual being, and to show by its terrified actions that it had done so.
There are but a few words to be said by way of epilogue.

Some of the objections that have been made to the future life of the lower animals have already been mentioned, but there are two other's which I must briefly notice. One is that, if all created beings are to live etemally in heaven, there would not be room for them. I feel almost ashamed even. to mention such an absurd notion, but as it has been put forward by several persons I feel bound to notice it.

'The answer is self-evident. In the first place, in the spiritual world space and time do not exist ; and even if they did, surely God can create space, if he has need of it.

'I'he second objection is that by granting immortality to the animals we lower the condition of luumanity; but if the animals be immortal there is surely no nse in denying it. We can not shirk a fact, and eren if we could we ought not to do so. Such an argument, moreover, is not very creditable to humanity, for it seeks to elevate man by depreciating his fellow-creatures of a lower order.

In announcing $m y$ belief that the lower animals share immortality with man in the next world, as they share mortality in this, I do not claim for them the slightest equality. Man will be man, and beast will be beast, and insect will be insect, in the next world as in this. They are living exponents of divine ide:s, as is evident from the Ioly Scriptures, and will be wanted to continue in the world of spirit the work which they have begun in the world of matter.

But, though I do not claim for them the slightest equality with man, I do claim for them a higher statns in creation than is generally attributed to them; I do claim for them a future life, in which they can be compensated for the sufferings which so many of them have to undergo in this world; and I do so chiefly because I am quite sure that most of the cruelties which are perpetrated on the animals are due to the habit of considering them as mere machines, without susceptibilities, without reason, and without the calpacity of a future. 




, r... 


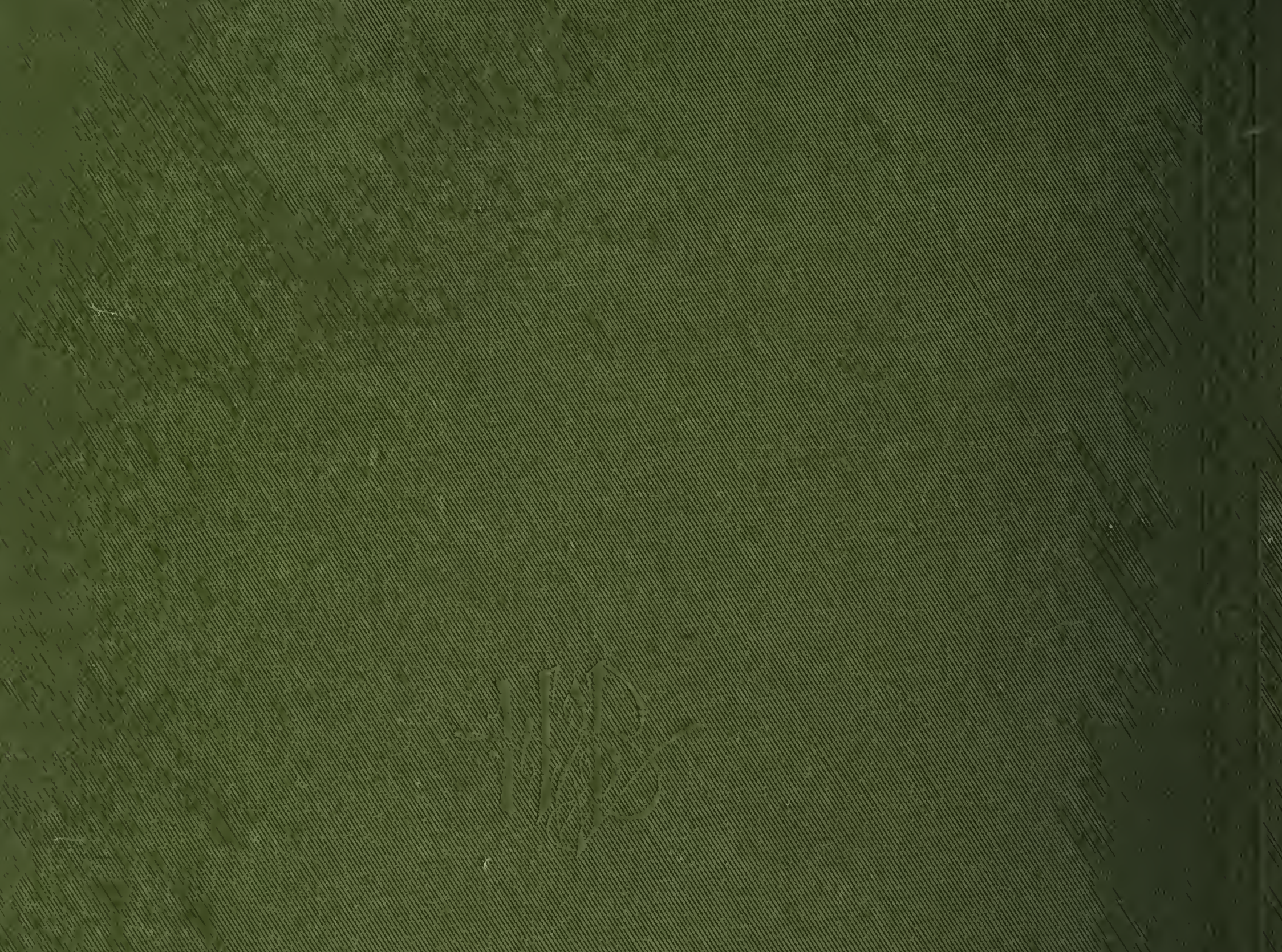